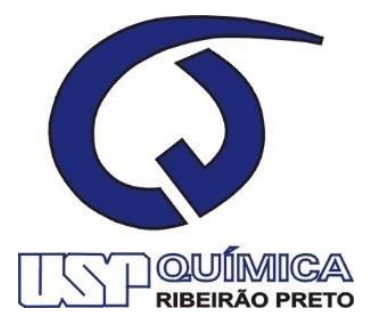

Universidade de São Paulo

Faculdade de Filosofia, Ciências e Letras de Ribeirão Preto

Departamento de Química

Programa de Pós-Graduação em Química

\title{
Desenvolvimento de filmes biodegradáveis a partir do resíduo da extração de corante de urucum
}

\author{
Thamiris Maria Garcia Silveira
}

Dissertação apresentada à Faculdade de Filosofia, Ciências e Letras de Ribeirão Preto da Universidade de São Paulo, como parte das exigências para a obtenção do título de Mestre em Ciências.

Área de concentração: Química

Orientadora: Prof ${ }^{a}$. Dr ${ }^{\mathrm{a}}$. Delia Rita Tapia Blácido

\section{Versão Corrigida}

(Versão original encontra-se na unidade que aloja o Programa de Pós-Graduação)

\author{
RIBEIRÃO PRETO - SP
}


Autorizo a reprodução e divulgação total ou parcial deste trabalho, por qualquer meio convencional ou eletrônico, para fins de estudo e pesquisa, desde que citada a fonte.

FICHA CATALOGRÁFICA

Silveira, Thamiris Maria Garcia

Desenvolvimento de filmes biodegradáveis a partir do resíduo da extração de corante de Urucum. Ribeirão Preto, SP, 2017.

141p: $30 \mathrm{~cm}$

Dissertação de Mestrado, apresentada à Faculdade de Filosofia, Ciências e Letras de Ribeirão Preto da USP.

Área de concentração: Departamento de Química.

Orientadora: Tapia-Blácido, Delia Rita.

Versão Corrigida, versão original disponível na Unidade.

1. Urucum. 2. Bixina. 3. Amido. 4. Filmes biodegradáveis. 


\section{FOLHA DE APROVAÇÃO}

\section{Silveira, Thamiris Maria Garcia}

Título: Desenvolvimento de filmes biodegradáveis a partir do resíduo da extração de corante de Urucum

Dissertação apresentada à Faculdade de Filosofia, Ciências e Letras de Ribeirão Preto da Universidade de São Paulo, como parte das exigências para a obtenção do título de Mestre em Ciências.

Área de concentração: Química.

Orientadora: Prof ${ }^{\mathrm{a}}$. Dr ${ }^{\mathrm{a}}$. Delia Rita Tapia Blácido.

Aprovado em:

Banca Examinadora

Dr. Instituição

Julgamento: Assinatura:

Dr. Instituição

Julgamento: Assinatura:

Dr. Instituição

Julgamento: Assinatura:

Dr. Instituição

Julgamento: Assinatura: 


\section{DEDICATÓRIA}

Àqueles que alimentam a minha vontade de vencer! Jeam, papai e mamãe! 


\section{AGRADECIMENTOS}

Este trabalho foi desenvolvido e concluído graças à minha dedicação e a contribuição de todas as pessoas que tive o privilégio em conhecer durante estes dois anos. Quero aqui, partilhar os resultados alcançados.

Agradeço a Deus por sempre estar comigo, abençoando meus planos e renovando minhas energias para sempre seguir em frente.

Aos meus pais, Fernando e Télvia, que mesmo distantes se fizeram presentes nos meus dias através do amor, de palavras de incentivo e apoio na realização de meus sonhos. A minha irmã, minha gratidão pelos meus sobrinhos que me enchem de alegria, João Gabriel e Luís Gustavo. Agradeço também as orações e torcida de toda minha família.

Ao meu noivo, Jeam, por todo amor, carinho, respeito, paciência e cuidado. Sem você e seu incentivo, talvez eu pudesse ter seguido outros caminhos. Amo você!

Agradeço à UFLA e professores pela minha formação e os amigos da Engenharia de Alimentos.

À minha orientadora, professora Delia, gratidão por me receber em seu grupo, pelas oportunidades, orientação, paciência, conselhos e amizade.

À Professora Márcia da Faculdade de Ciências Farmacêuticas da USP-RP por ceder seu laboratório, pelas orientações e confiança. Agradeço também ao seu técnico Luciano, pela paciência e orientações, que muito contribuíram na realização dos experimentos

Agradeço todos os técnicos pelos trabalhos prestados que tanto foram importantes para conclusão do projeto. São eles Lourivaldo do DFRX, Rodrigo do MEV, meninos do FTIR, Mércia do HPLC, a Janaína pelos almoços e amizade. Agradeço também os professores das disciplinas cursadas. Em especial, professor Beto, sua aluna Júlia, professora Maria de Lourdes, sua aluna Luciana.

Agradeço o pessoal do Laboratório Inbran, da Física-Médica pela acolhida e amizade. Obrigada Felipe Barreto por fotografar os frutos, os amidos e farelos. Obrigada ao Gustavo e Mário por cederem sua casa nos meses iniciais. 
Agradeço ao pessoal da República Moita pela amizade, por vibrarem cada passo dado. Em especial, Gustavo Abrão, Francine e Maria Eduarda, amigos de coração, vocês foram minha família em Ribeirão. Agradeço a Bianca Martins pelo carinho, amizade e atenção.

E muita gratidão aos amigos que fiz aqui. Natália, Larissa, Bruno, Douglas, Lucas, Milena, Guilherme. A Malori Gyon pela oportunidade de contato com sua cultura e pelos experimentos realizados que muito contribuiram para passos futuros na conclusão deste trabalho. Um agradecimento especial à Denisse e Bianca pelas orientações, apoio, incentivo e amizade. À Roberta, Bruna, Thalita, Vinícius pela alegria, positividade, caronas. Enfim, levo um pouco de cada um e tenho a certeza que sem cada um de vocês tudo teria sido sem graça.

Agradeço a banca por aceitarem o convite e contribuição final.

Agradeço a CAPES pela bolsa concedida e ao Departamento de Química da Faculdade de Filosofia, Ciências e Letras da Universidade de São Paulo por toda a estrutura cedida paraa execução deste trabalho. 
“É o tempo da travessia:

E se não ousarmos fazê-la, teremos ficado, para sempre, à margem de nós mesmos." Fernando Pessoa 
Silveira, Thamiris Maria Garcia Silveira. Desenvolvimento de filmes biodegradáveis a partir do resíduo da extração de corante de urucum. 2017.141p. Dissertação (Mestrado) Faculdade de Filosofia, Ciência e Letras de Ribeirão Preto, Universidade de São Paulo, Ribeirão Preto, 2017.

\section{RESUMO}

O principal objetivo deste trabalho foi o aproveitamento do resíduo agroindustrial proveniente da extração do pigmento de urucum para elaboração de filmes biodegradáveis. Foram empregados três métodos (moagem em água (WS), moagem em pH ácido (AS) e moagem em $\mathrm{pH}$ alcalino (KS)) para isolamento de farinha de urucum. O resíduo e farinhas foram caracterizados em composição centesimal, cor, distribuição do tamanho de partícula, difração de raios-X, microscopia eletrônica de varredura, espectroscopia de infravermelho, calorimetria diferencial de varredura, teor de compostos fenólicos, carotenoides, teor de bixina e atividade antioxidante. $\mathrm{O}$ método KS proporcionou farinha com maior teor de amido e amilose, porém com menor teor de compostos ativos quando comparada as farinhas WS e AS. Estas farinhas foram utilizadas para a produção dos filmes em diferentes condições de $\mathrm{pH}(5,7,9)$ e tempo de aquecimento (1h, 2h, 3h, 4h) segundo o planejamento fatorial completo $3 \times 3 \times 4$. De acordo com o planejamento as melhores condições foram pH 5 e tempo de aquecimento de 2 horas para os filmes de farinha KS. Foram produzidos filmes de farinha KS na melhor condição e caracterizados em suas propriedades mecânicas, funcionais e ativas, para serem comparados aos filmes de farinha WS e AS. Filmes de farinha KS foram mais hidrofóbicos, mais permeáveis ao vapor de água, mais resistentes mecanicamente, contudo apresentaram menor conteúdo de compostos ativos. Os filmes de farinhas WS e AS são menos permeáveis ao vapor de água, mais úmidos, mais solúveis, mais hidrofílicos, mais ativos e de maior capacidade de absorção de água quando comparados aos filmes de farinha KS, contudo menos resistentes mecanicamente. A atividade antimicrobiana de extrato hidro-alcoólico de sementes de urucum e extrato de cúrcuma, assim como os filmes de farinha de urucum WS, AS, KS foram testados pelo método de difusão em ágar contra bactérias e fungos filamentosos. Os extratos de urucum e cúrcuma apresentaram eficiência antimicrobiana contra S. aureus, S. uberis e S. agalactiae, além de $C$. albicans para cúrcuma. O extrato de urucum reduziu a esporulação dos fungos $A$. fumigatus e Mucor sp., enquanto o extrato de cúrcuma reduziu a esporulação dos fungos $A$. tamarii, A. flavus, F. oxysporum e P. expansum. Já no caso dos filmes, apenas o filme elaborado com farinha KS apresentou boa atividade contra S. aureus, S. uberis, E. coli, P. aeruginosa, L. monocytogenes e C. albicans. PALAVRAS-CHAVE: urucum, bixina, amido, filmes biodegradáveis, antioxidante, antimicrobiano. 
Silveira, Thamiris Maria Garcia Silveira. Development of biodegradable films from the residue of Urucum dye extraction. 2017. 141p. Dissertação (Mestrado) - Faculdade de Filosofia, Ciência e Letras de Ribeirão Preto, Universidade de São Paulo, Ribeirão Preto, 2017.

\begin{abstract}
The main objective of this work was the use of the agroindustrial residue from the extraction of the annatto pigment for the elaboration of biodegradable films. Three methods (water milling (WS), acid $\mathrm{pH}(\mathrm{AS})$ grinding and alkaline $\mathrm{pH}(\mathrm{KS})$ milling were used for insulation of urucum flour. The residue and flours were characterized in centesimal composition, color, particle size distribution, X-ray diffraction, scanning electron microscopy, infrared spectroscopy, differential scanning calorimetry, phenolic compounds content, carotenoids, bixin content and activity Antioxidant. The KS method provided flour with higher content of starch and amylose, but with a lower content of active compounds when compared to WS and AS flours. These flours were used to produce the films in different $\mathrm{pH}$ conditions $(5,7,9)$ and heating time $(1 \mathrm{~h}$, $2 \mathrm{~h}, 3 \mathrm{~h}, 4 \mathrm{~h}$ ) according to the complete $3 \times 3 \times 4$ factorial design. According to the planning the best conditions were $\mathrm{pH} 5$ and heating time of 2 hours for the KS flour films. KS flour films were produced in the best condition and characterized in their mechanical, functional and active properties, to be compared to the WS and AS flour films. KS flour films were more hydrophobic, more permeable to water vapor, more mechanically resistant, yet presented lower content of active compounds. The WS and AS flours films are less permeable to water vapor, moist, more soluble, more hydrophilic, more active and with a higher water absorption capacity when compared to KS flour films, but less mechanically resistant. The antimicrobial activity of aqua-alcoholic extract of urucum seeds and turmeric extract, as well as the WS, AS, KS urucum flour films were tested by the agar diffusion method against bacteria, fungi and yeast. Urucum and turmeric extracts presented antimicrobial efficiency against $S$. aureus, S. uberis and $S$. agalactiae, as well as C. albicans for turmeric. The urucum extract reduced the sporulation of the fungi $A$. fumigatus and Mucor sp., while the turmeric extract reduced the sporulation of the fungi A. tamarri, A. flavus, F. oxysporum and P. expansum. In the case of the films, only the film prepared with KS flour showed good activity against S. aureus, S. uberis, E. coli, P. aeruginosa, L. monocytogenes and C. albicans.
\end{abstract}

KEY WORDS: annatto, bixin, starch, biodegradable films, antioxidant, antimicrobial. 


\section{ÍNDICE DE FIGURAS}

Figura 1.1 - (A) Foto do urucuzeiro (Bixa orellana), do (B) fruto urucum aberto com exposição das sementes e do $(\mathrm{C})$ resíduo da extração do corante de urucum ........................................... 10

Figura 1.2 - Fórmulas estruturais da bixina e norbixina ................................................ 12

Figura 1.3 - Reações químicas para obtenção de corante norbixina de urucum utilizando

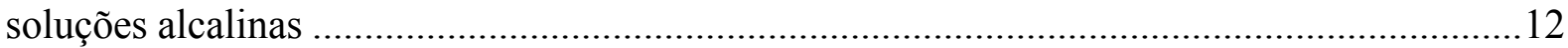

Figura 1.4 - Reações de isomerização dos pigmentos de urucum ........................................... 13

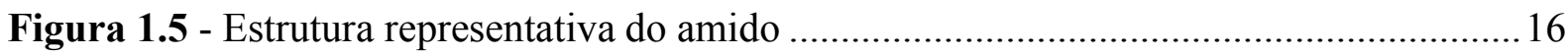

Figura 1.6 - Estrutura da (A) amilose e (B) amilopectina ................................................. 16

Figura 2.1 - Fluxograma do processo de isolamento de farinhas a partir do resíduo da extração de corante de urucum por moagem em água (WS), moagem em pH ácido (AS) e moagem em $\mathrm{pH}$ alcalino (KS)

Figura 2.2 - Esquema do sistema tridimensional representativo das coordenadas dos parâmetros de cor e da diferença de cor total $\left(\Delta \mathrm{E}^{*}\right)$

Figura 2.3 - Resíduo da extração de corante de urucum, farinhas e farelos obtidos nos métodos por moagem em água (WS), moagem em $\mathrm{pH}$ ácido (AS) e moagem em $\mathrm{pH}$ alcalino (KS)......54

Figura 2.4 - Distribuição do tamanho das partículas do resíduo da extração de corante de urucum e farinhas isoladas por moagem em água (WS), moagem em pH ácido (AS) emoagem em $\mathrm{pH}$ alcalino (KS)

Figura 2.5 - Micrografias obtidas por MEV do resíduo de urucum

Figura 2.6 - Micrografias obtidas por MEV das farinhas isoladas por (A-B) moagem emágua, (C-D) moagem em pH ácido, (E-F) moagem em $\mathrm{pH}$ alcalino.

Figura 2.7 - Micrografias obtidas por MEV dos farelos resultantes do isolamento por (A-B) moagem em água, (C-D) moagem em pH ácido, (E-F) moagem em pH alcalino ...................64

Figura 2.8 - Termograma de DSC de resíduo e farinhas WS, AS e KS...............................66

Figura 2.9 - Difratograma de raios-X (A) resíduo da extração de corante de urucum, farinhas isoladas por moagem em água (WS), moagem em $\mathrm{pH}$ ácido (AS), moagem em meio alcalino $(\mathrm{KS})$ e (B) respectivos farelos

Figura 2.10 - FTIR (A) do resíduo da extração de corante de urucum, farinhas isoladas por moagem em água (WS), moagem em $\mathrm{pH}$ ácido (AS), moagem em $\mathrm{pH}$ alcalino (KS) e (B)

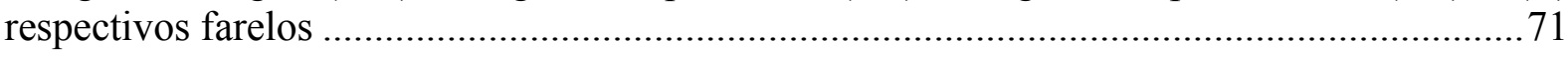

Figura 3.1- Fluxograma de elaboração dos filmes de urucum por método casting .................. 80 
Figura 3.2 - Esquema do corpo de prova para teste de tração

Figura 3.3 - Esquema do meio utilizado para determinar a permeabilidade ao vapor de água PVA

Figura 3.4 - Esquema ilustrativo do ângulo de contato formado pela gota depositada sobre a superfície do filme

Figura 3.5 - Tensão dos filmes de farinha de urucum isolados por métodos WS, AS e KS elaborados em diferentes $\mathrm{pH}(5,7,9)$ e tempo de aquecimento (1h, $2 \mathrm{~h}, 3 \mathrm{~h}, 4 \mathrm{~h})$

Figura 3.6 - Módulo de Young dos filmes de farinha de urucum isolados por método WS, AS e KS elaborados em diferentes $\mathrm{pH}(5,7,9)$ e tempo de aquecimento ( $\mathrm{h}, 2 \mathrm{~h}, 3 \mathrm{~h}, 4 \mathrm{~h})$

Figura 3.7 - Elongação dos filmes de farinha de urucum isolados por método WS, AS e KS elaborados em diferentes $\mathrm{pH}(5,7,9)$ e tempo de aquecimento (1h, $2 \mathrm{~h}, 3 \mathrm{~h}, 4 \mathrm{~h})$ 92

Figura 3.8 - Umidade dos filmes de farinha de urucum isolados por método WS, AS e KS elaborados em diferentes $\mathrm{pH}(5,7,9)$ e tempo de aquecimento $(1 \mathrm{~h}, 2 \mathrm{~h}, 3 \mathrm{~h}, 4 \mathrm{~h})$ 98

Figura 3.9 - Solubilidade dos filmes de farinha de urucum isolados por método WS, AS e KS elaborados em diferentes $\mathrm{pH}(5,7,9)$ e tempo de aquecimento $(1 \mathrm{~h}, 2 \mathrm{~h}, 3 \mathrm{~h}, 4 \mathrm{~h})$

Figura 3.10 - PVA dos filmes de farinha de urucum isolados por método WS, AS e KS elaborados em diferentes $\mathrm{pH}(5,7,9)$ e tempo de aquecimento $(1 \mathrm{~h}, 2 \mathrm{~h}, 3 \mathrm{~h}, 4 \mathrm{~h})$.

Figura 3.11 - Capacidade de absorção de água dos filmes elaborados com diferentes farinhas de urucum (WS, AS, KS)..... 106

Figura 4.1 - Aparência dos filmes elaborados com as farinhas de urucum AS, WS e KS 118

Figura 4.2 - Avaliação da atividade antimicrobiana dos extratos hidro-alcoólicos de urucum e cúrcuma contra fungos filamentosos

Figura 4.3 - Avaliação da atividade antimicrobiana dos extratos hidro-alcoólicos de urucum e cúrcuma contra bactérias e levedura

Figura 4.4 - Teste do halo dos filmes de farinhas de urucum (WS, AS e KS) com Staphylococcus aureus $\left(5 \times 10^{4} \mathrm{UFC}\right)$.

Figura 4.5 - Teste do halo dos filmes de farinhas de urucum (WS, AS e KS) com Staphylococcus uberis $\left(5 \times 10^{4} \mathrm{UFC}\right)$.. 128

Figura 4.6 - Teste do halo dos filmes de farinhas de urucum (WS, AS e KS) com Staphylococcus agalactiae ( $\left.5 \times 10^{4} \mathrm{UFC}\right)$.

Figura 4.7 - Teste do halo dos filmes de farinhas de urucum (WS, AS e KS) com Listeria monocytogenes $\left(5 \times 10^{4} \mathrm{UFC}\right)$.

Figura 4.8 - Teste do halo dos filmes de farinhas de urucum (WS, AS e KS) com Pseudomonas 
aeroginosa $\left(5 \times 10^{4} \mathrm{UFC}\right)$

4.9 - Teste do halo dos filmes de farinhas de urucum (WS, AS e KS) com Escherichia coli (5 $\left.\mathrm{x} 10^{4} \mathrm{UFC}\right)$

Figura 4.10 - Teste do halo dos filmes de farinhas de urucum (WS, AS e KS) com Candida albicans $\left(5 \times 10^{4} \mathrm{UFC}\right)$

Figura 4.11 - Teste do halo dos filmes de farinhas de urucum (WS, AS e KS) com Aspergillus fumigatus $\left(5 \times 10^{4} \mathrm{UFC}\right)$.

Figura 4.12 - Teste do halo dos filmes de farinhas de urucum (WS, AS e KS) com Aspergillus tamarri $\left(5 \times 10^{4} \mathrm{UFC}\right)$

Figura 4.13 - Teste do halo dos filmes de farinhas de urucum (WS, AS e KS) com Fusarium oxysporum $\left(5 \times 10^{4} \mathrm{UFC}\right)$.

Figura 4.14 - Teste do halo dos filmes de farinhas de urucum (WS, AS e KS) com Mucor $s p$ $\left(5 \times 10^{4} \mathrm{UFC}\right)$

Figura 4.15 - Teste do halo dos filmes de farinhas de urucum (WS, AS e KS) com Aspergillus flavus $\left(5 \times 10^{4} \mathrm{UFC}\right)$

Figura 4.16 - Teste do halo dos filmes de farinhas de urucum (WS, AS e KS) comPenicillium expansum $\left(5 \times 10^{4} \mathrm{UFC}\right)$. 134 


\section{ÍNDICE DE TABELAS}

Tabela 1 - Composição centesimal do resíduo da extração de corante de urucum.

Tabela 2.1 - Composição química e rendimento de farinhas e farelos obtidos de resíduo da extração de corante de urucum por diferentes métodos de isolamento

Tabela 2.2 - Parâmetros de cor $\left(\mathrm{L}^{*}, \mathrm{a}^{*}, \mathrm{~b}^{*}\right)$ e diferença de cor $\left(\Delta \mathrm{E}^{*}\right)$ de resíduo da extração de corante de urucum, farinhas e farelos obtidos por diferentes isolamentos

Tabela 2.3 - Compostos fenólicos totais, carotenoides totais, teor de bixina e atividade antioxidante (AA) em resíduo da extração de corante de urucum, farinha e farelos obtidos por diferentes métodos de isolamento

Tabela 2.4 - Valores de temperatura e entalpia do intervalo de gelatinização dos amidos presentes no resíduo da extração de corante de urucum e nas farinhas obtidas por diferentes métodos de isolamento

Tabela 3.1 - Resultados das propriedades mecânicas dos filmes de farinha de urucum. .86

Tabela 3.2 - Valores de "p" da tabela da ANOVA para as propriedades mecânicas.

Tabela 3.3 - Resultados das propriedades funcionais dos filmes de farinha de urucum.

Tabela 3.4 -Valores de "p" da tabela da ANOVA parapropriedades funcionais

Tabela 3.5 - Espessura e propriedades mecânicas dos filmes elaborados com diferentes farinhas de urucum 101

Tabela 3.6 - Comparação das propriedades mecânicas de filmes elaborados com polímeros de diferentes fontes.

Tabela 3.7 - Propriedades funcionais dos filmes elaborados com diferentes farinhas de urucum.

Tabela 4.1 - Fenólicos totais, carotenoides totais, teor de bixina e atividade antioxidante de filmes de farinha de urucum

Tabela 4.2 - Atividade antimicrobiana de extratos de urucum, e cúrcuma 


\section{LISTA DE ABREVIATURAS E SIGLAS}

WS - Moagem em água

AS - Moagem em pH ácido

$\mathrm{KS}$ - Moagem em $\mathrm{pH}$ alcalino

MEV- Microscopia eletrônica de varredura.

AOAC - Association of Official Analytical Chemists.

ASTM - American Society for Testing and Materials.

DSC - Differential Scanning Calorimetry.

$\mathrm{T}_{\mathrm{i}}$ : Temperatura de início.

$T_{p}$ : Temperatura pico de gelatinização.

$\mathrm{T}_{\mathrm{f}}$ : Temperatura final.

$\Delta \mathrm{H}$ : Entalpia de gelatinização.

FTIR - Fourier transform infrared spectroscopy.

DRX - Difração de Raios-X.

L* - Luminosidade.

$a^{*}, b^{*}$ - Parâmetros de cromaticidade.

$\Delta \mathrm{E}^{*}$ - Diferença de cor.

$2 \theta$ - Ângulo de Bragg.

N:P - Nitrogênio:Proteína

ABTS - Radical, (2,2-azinobis-[3-etil-benzotiazolin-6-ácido sulfônico]).

Trolox - Antioxidante sintético, (6-hidroxi-2,5,7,8-tetrametilcromo-2-ácido carboxílico).

TE - Trolox equivalente.

AA - Atividade antioxidante (\%)

CFT - Compostos fenólicos totais.

EAG - Equivalente ácido gálico.

PVA: Permeabilidade ao vapor de água.
A: Área $\left(\mathrm{m}^{2}\right)$.
t: Tempo (s).
T: Temperatura $\left({ }^{\circ} \mathrm{C}\right)$

FTIR - Fourier transform infrared spectroscopy. 
IBGE - Instituto Brasileiro de Geografia e Estatística.

CNNPA - Comissão Nacional de Normas e Padrões para Alimentos.

ANVISA - Agência Nacional de Vigilância Sanitária.

$\alpha, \beta, \gamma$ e $\delta$ - Prefixos que indicam número e posição do grupo metila ligado ao anel aromático do composto fenólico.

E de E160b - Referência atribuída ao corante de urucum pela União Européia.

H - Hora.

Mesh - Número de aberturas por polegada linear.

Min - Minuto.

EUA - Estados Unidos da América.

DLS - Espalhamento de luz dinâmico.

HPLC - High performance liquid chromatography.

UR - umidade relativa.

b.s - base seca (g água/100 g sólidos secos).

b.u - base úmida (g água/100 g sólidos totais).

a.d - amostra desengordurada.

CIM - concentração inibitória mínima.

S. aureus - Sthapylococcus aureus.

S. uberis - Sthapylococcus uberis.

S. agalactiae - Sthapylococcus agalactiae.

E. coli-Escherichia coli.

P. aeruginosa-Pseudomonas aeruginosa.

L. monocytogenes - Listeria monocytogenes.

C. albicans - Candida albicans.

A. fumigatus - Aspergillus fumigatus.

A. tamarii - Aspergillus tamarii.

A. flavus - Aspergillus flavus.

F. oxysporum - Fusarium oxysporum.

P. expasum - Penicillium expansum 


\section{SUMÁRIO}

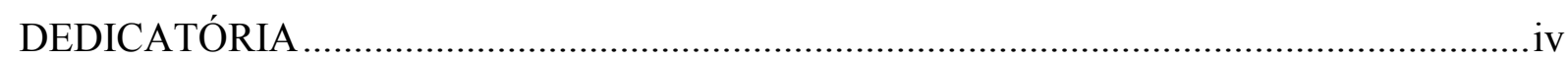

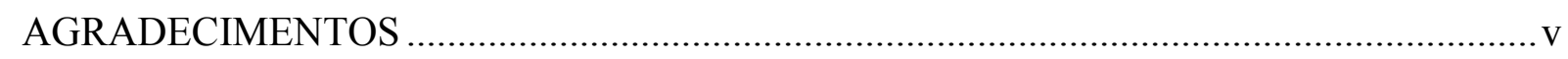

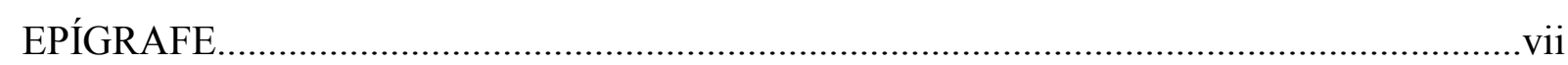

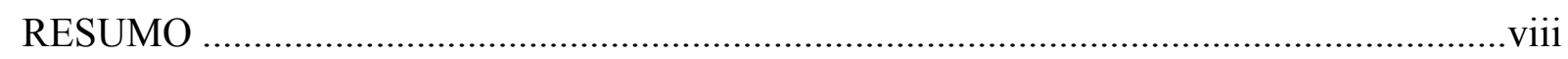

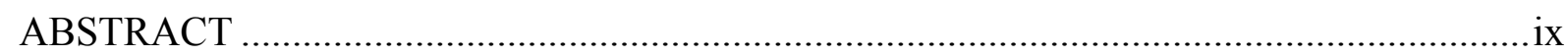

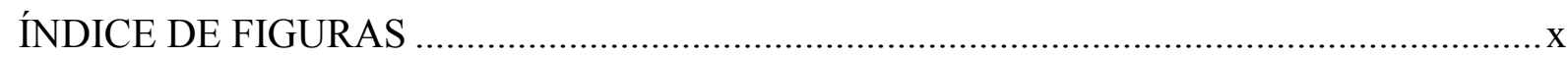

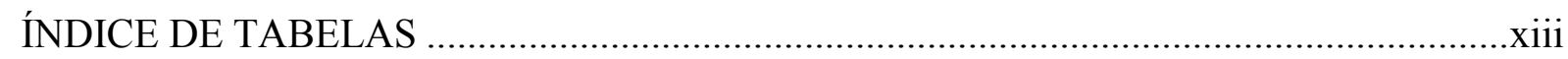

LISTA DE ABREVIATURAS E SIGLAS .....................................................................

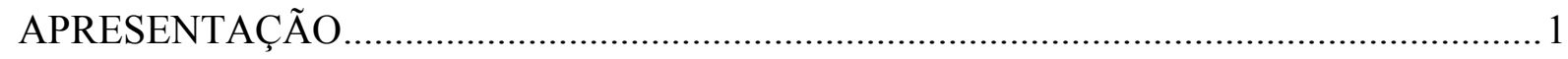

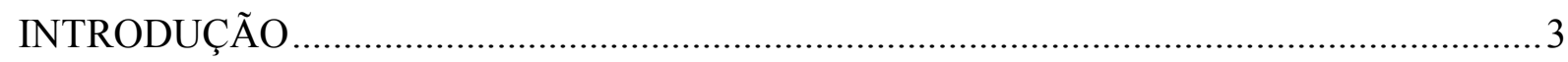

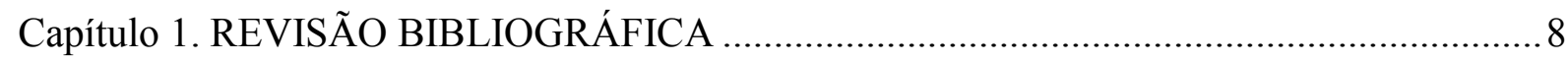

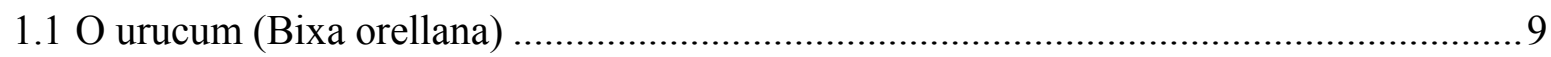

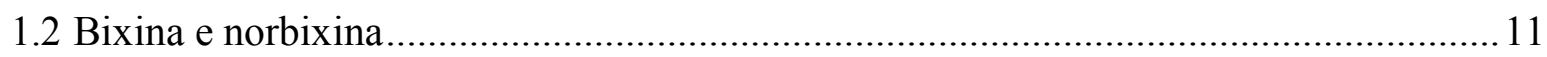

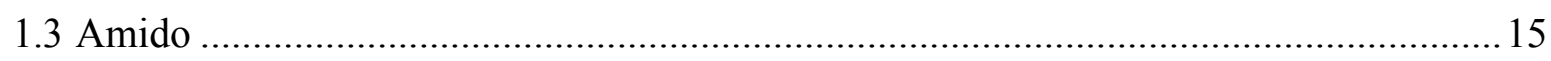

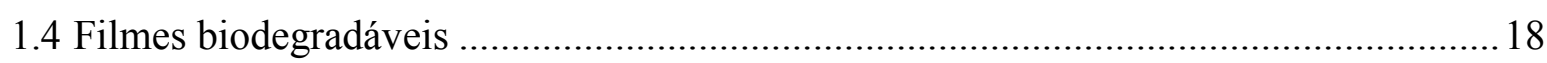

1.5 Filmes biodegradáveis à base de farinha e/ou resíduos agroindustriais......................... 19

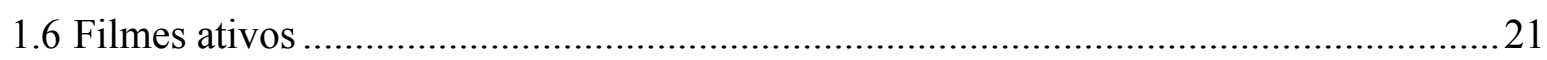

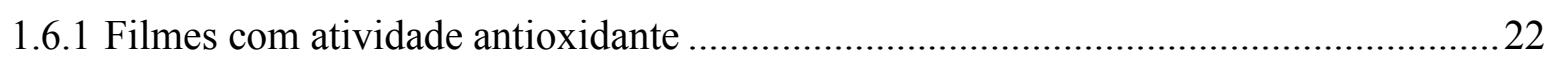

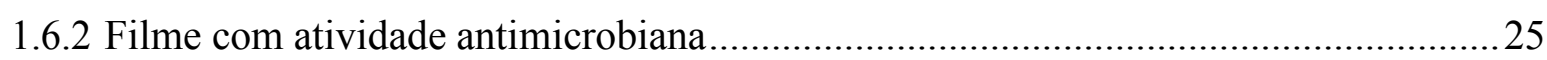

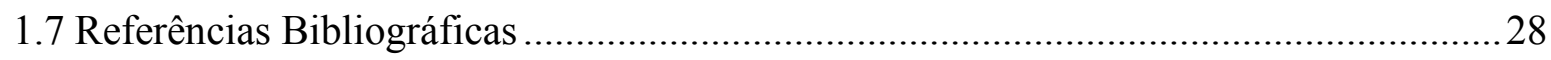

Capítulo 2. EFEITO DO MÉTODO DE ISOLAMENTO DE AMIDO A PARTIR DO

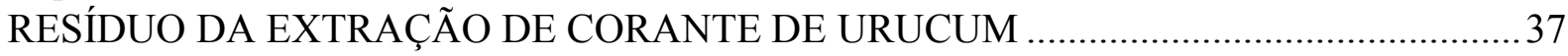

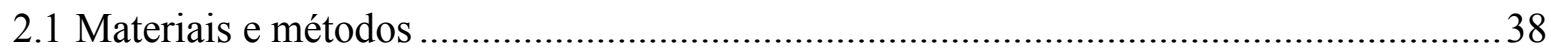

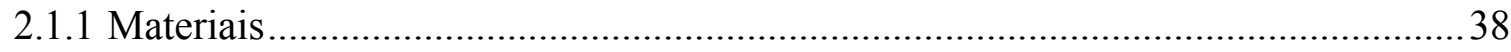

2.1.2 Isolamento de farinhas a partir do resíduo da extração do corante de urucum .........39

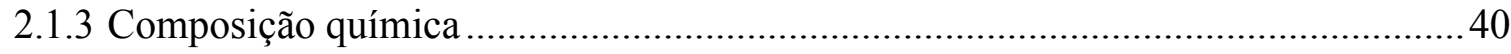

2.1.4 Distribuição do tamanho de partículas ......................................................................... 46

2.1.5 Microscopia eletrônica de varredura (MEV) ........................................................... 46

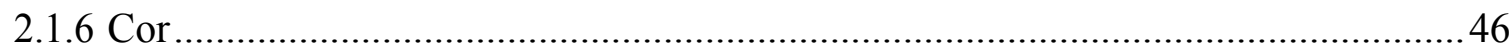

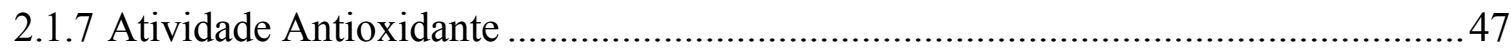

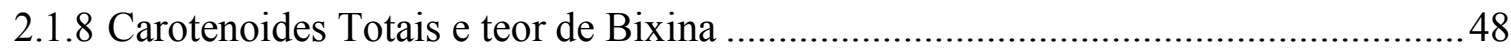

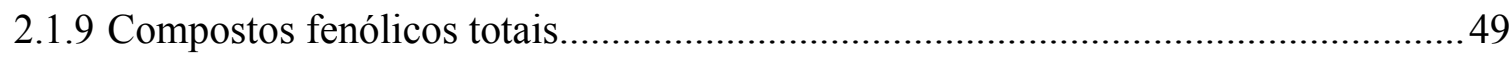




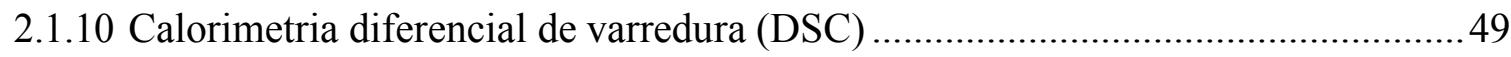

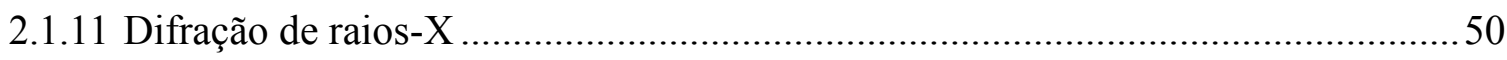

2.1.12 Espectroscopia de absorção na região do infravermelho (FTIR) ...........................50

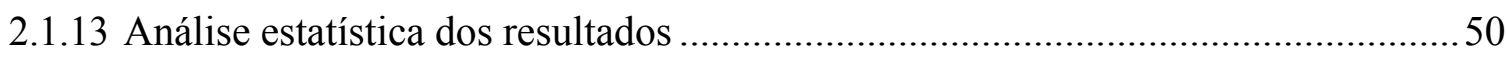

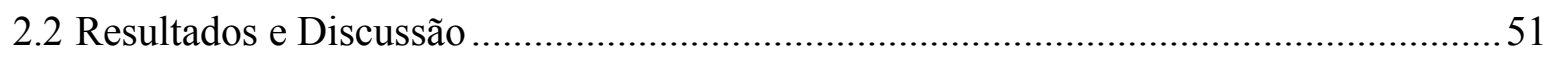

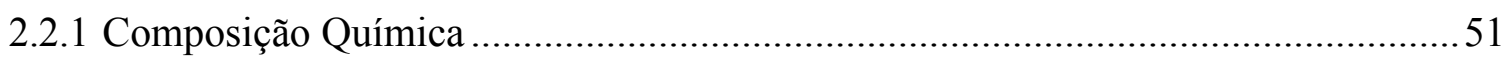

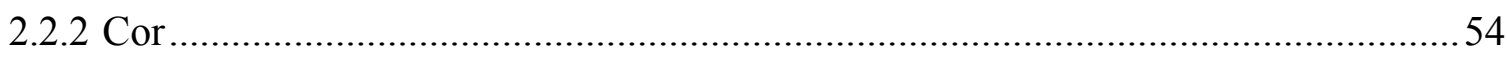

2.2.3 Compostos fenólicos totais, carotenoides totais, teor de bixina e atividade

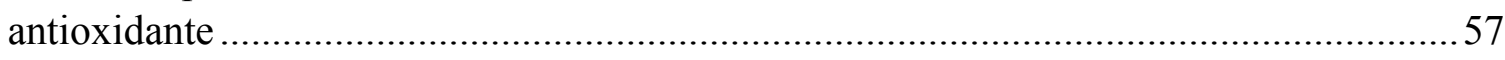

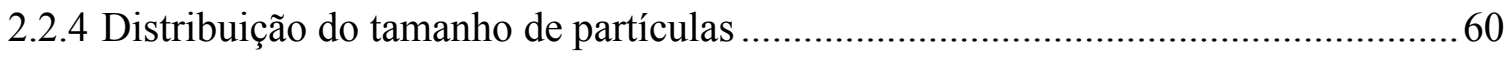

2.2.5 Morfologia por Microscopia Eletrônica de Varredura (MEV) ................................. 61

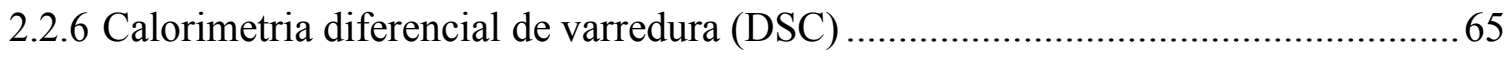

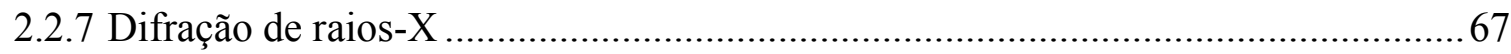

2.2.8 Espectroscopia de absorção na região do infravermelho (FTIR) ............................69

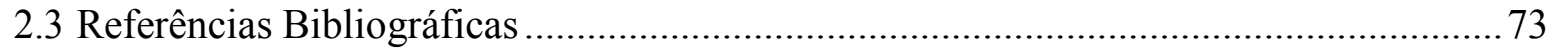

Capitulo 3. FILMES BIODEGRADÁVEIS A BASE DE FARINHA OBTIDA DO RESÍDUO

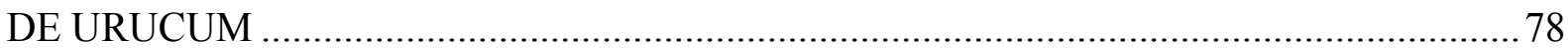

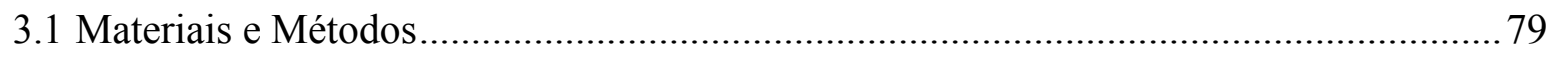

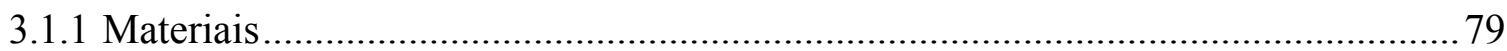

3.1.2 Elaboração dos filmes de farinha de urucum ......................................................... 79

3.1.3 Caracterização dos filmes de farinha de urucum................................................. 81

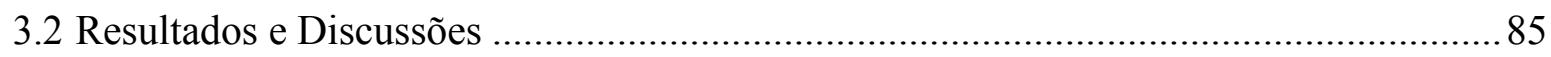

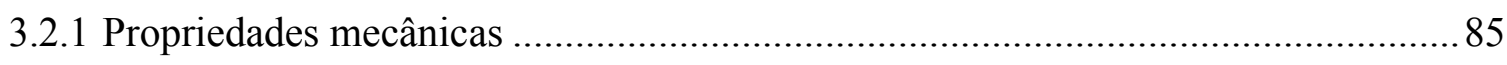

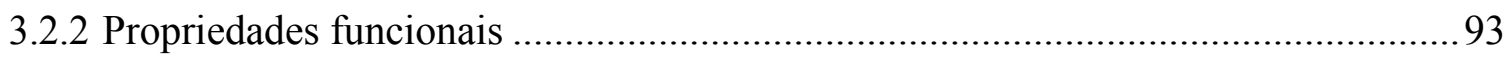

3.2.3 Caracterização dos filmes de farinha de urucum na formulação escolhida ........... 101

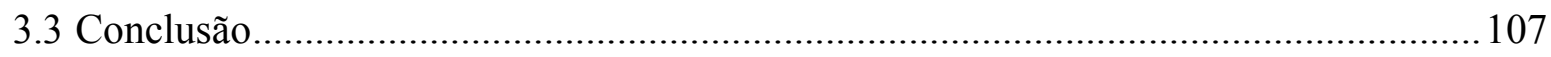

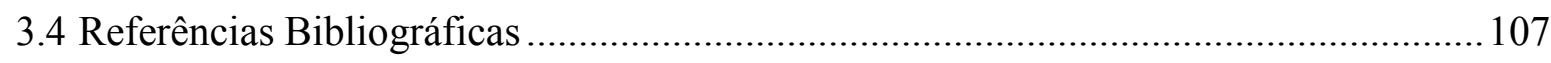

Capítulo 4. PROPRIEDADES BIOATIVAS E ATIVIDADE ANTIMICROBIANA........... 111

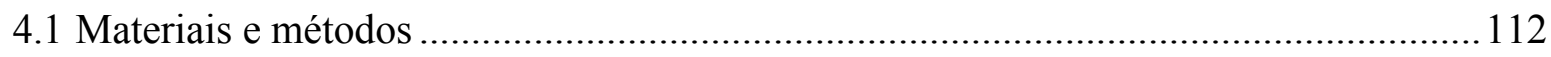

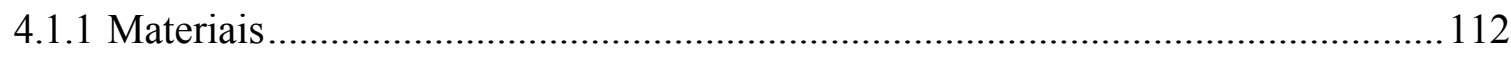

4.1.2 Determinação dos compostos ativos ................................................................. 113

4.1.3 Preparo do extrato das sementes de urucum e do rizoma de cúrcuma .................... 115

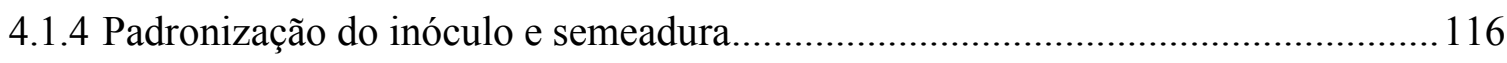

4.1.5 Atividade antimicrobiana do extrato de urucum e do extrato de cúrcuma............. 117

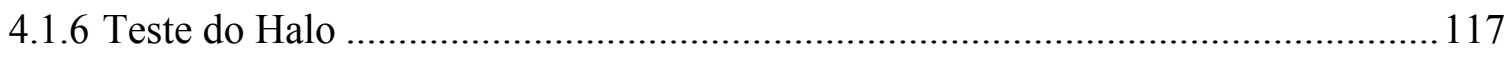

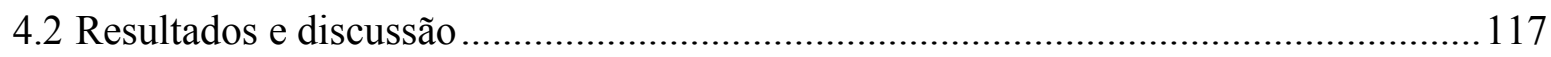




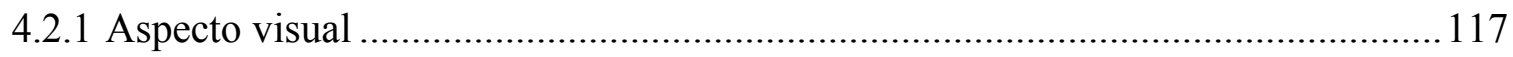

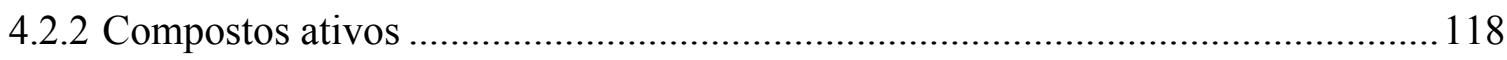

4.2.3 Atividade antimicrobiana dos extratos de urucum e cúrcuma ..............................120

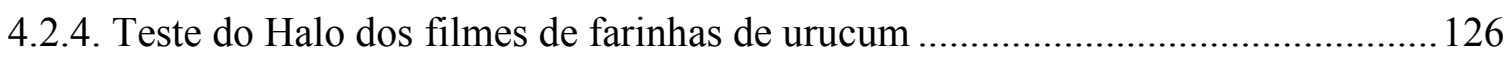

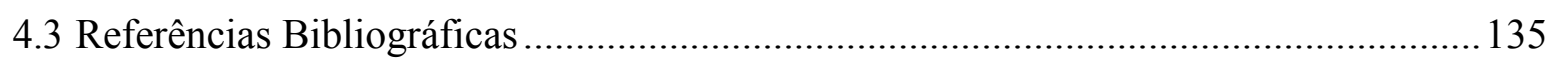

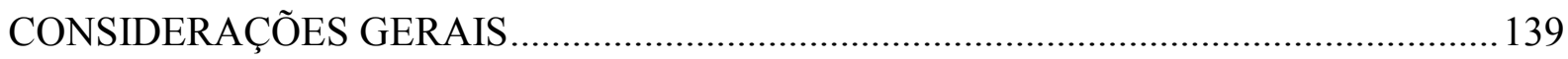

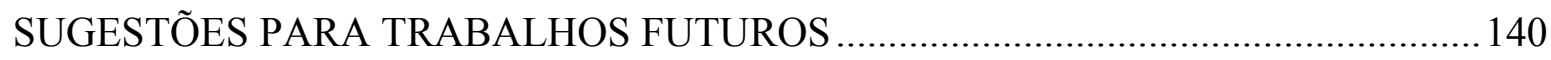

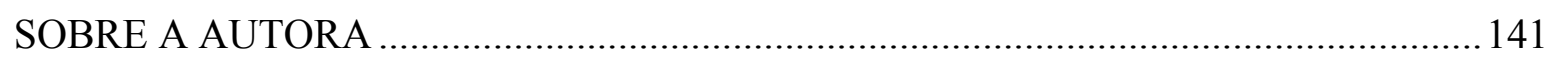




\begin{abstract}
APRESENTAÇÃO
É preocupante a rapidez de uso e descarte de plásticos sintéticos. O aumento da população mundial e os avanços tecnológicos estimulam a produção industrial. Simultaneamente, crescem a geração de resíduos prejudiciais ao meio ambiente. As indústrias processadoras vivenciam a dificuldade em propor de maneira ecologicamente correta e economicamente viável o descarte de seus resíduos. O aproveitamento de resíduo agroindustrial tem sido uma boa alternativa na produção de filmes biodegradáveis, em função à interessante composição química e uma vez que, reduz os custos de produção tornando a embalagem mais competitiva quando comparada as embalagens sintéticas. O resíduo da extração de corante de urucum apresenta rica composição em amido e presença de compostos ativos que possibilitam a produção de filmes diferenciados, com características antioxidantes e antimicrobianas. Nessas circunstâncias, este trabalho visou avaliar o potencial de aproveitamento do resíduo da extração de corante de urucum na elaboração de filmes bioativos e biodegradáveis.
\end{abstract}

Este trabalho será apresentado nos seguintes capítulos:

- Capítulo 1: apresenta uma revisão bibliográfica sobre o urucum, bixina e norbixina, filmes biodegradáveis a base de farinhas e/ou resíduos agroindustriais, filmes ativos com propriedade antioxidante e antimicrobiana.

- Capítulo 2: relata processos de isolamento de farinha a partir do resíduo da extração de corante de urucum, utilizando três diferentes métodos moagem em água (WS), moagem em pH ácido (AS) e moagem em pH alcalino (KS). São apresentados neste capítulo as caracterizações do resíduo e materiais isolados.

- Capítulo 3: aborda o estudo dos efeitos do tipo de farinha de urucum (WS, KS e AS), $\mathrm{pH}(5,7,9)$ e tempo de aquecimento $(1 \mathrm{~h}, 2 \mathrm{~h}, 3 \mathrm{~h}$ e $4 \mathrm{~h})$ sobre as propriedades mecânicas e funcionais dos filmes de urucum utilizando um planejamento fatorial completo $3 \times 3 \times 4$. A partir dos resultados deste planejamento, foi escolhida a melhor condição para a elaboração de filmes de farinha de urucum com melhores propriedades mecânicas e funcionais. 
- Capítulo 4: relata as determinações dos compostos ativos presentes em filmes elaborados com as farinhas de urucum WS, AS e KS. Ainda neste capítulo, são apresentados testes de difusão em ágar de extrato hidro-alcoólico de urucum e extrato de cúrcuma, como também de filmes de farinha WS, AS, KS para avaliação da eficiência antimicrobiana contra bactérias, fungos e levedura. 


\section{INTRODUÇÃO}

Até pouco tempo, era importante o desenvolvimento de materiais duráveis e dentre estes materiais estavam os plásticos sintéticos, derivados de petróleo, com grande variedade de aplicações, em função as suas propriedades, versatilidade de uso e preço (HUANG, S. J.; EDELMAN, 1995).

Em 2015, a produção mundial de plásticos foi de 322 milhões de toneladas, segundo a associação européia dos produtores de plásticos, a PlasticsEurope (CAMPOS, 2016). Estes plásticos sintéticos são fabricados a partir de uma fonte não renovável, o petróleo e são resistentes à degradação natural, pois sua alta massa molar média combinada a hidrofobicidade dificultam a ação dos microrganismos e de suas enzimas na superfície do polímero (LEE; CHOI, 1998; ROSA et al., 2004). Estima-se que a quantidade de resíduos plásticos descartados no meio ambiente é aproximadamente $20 \%$ do volume total produzido em plásticos (LEÃO; TAN, 1998; HUANG, S. J.; EDELMAN, 1995). Alguns destes plásticos sintéticos podem exigir até 200 anos para sua degradação total. Diante dos alarmantes números de produção, rápido consumo e descarte incorreto dos plásticos, aliado a crescente conscientização da preservação ambiental, o mercado de plásticos biodegradáveis tem despertado interesse (PHILP; RITCHIE; GUY, 2013).

A produção de plástico biodegradável é uma alternativa de material ambientalmente adequado, pois dispensa petróleo e a degradação pode acontecer cerca de 20 dias, enquanto o plástico tradicional pode demorar até 500 anos para degradação completa (ALVES, 2003; CARR, 2006). O material será considerado biodegradável quando durante processo de degradação por ação enzimática de organismos vivos, como bactérias, leveduras, fungos e algas resultar produtos finais como o $\mathrm{CO}_{2}, \mathrm{H}_{2} \mathrm{O}$ e biomassa sob condições aeróbias e hidrocarbonetos, metano e biomassa em condições anaeróbicas (DOI \& FUKUDA, 1994).

Os filmes biodegradáveis são produzidos a partir de fontes renováveis, capazes de formar matrizes contínuas. Geralmente, biopolímeros como polissacarídeos, lipídeos, proteínas e derivados. No entanto, em termos econômicos, as embalagens produzidas a partir de biopolímeros não tem preço competitivo a curto prazo. Neste contexto, o aproveitamento de resíduos agroindustriais faz-se bastante interessante por estes apresentarem altos teores de biopolímeros formadores de filmes, como polissacarídeos e proteínas e por reduzir os custos de produção, tornando o plástico biodegradável mais competitivo no mercado de embalagens 
(AZEREDO et al., 2009; JACOMETTI et al., 2015; KAYA; MASKAN, 2003; MANIGLIA et al., 2014; 2015).

Há estudos de avaliação do potencial de aproveitamento de resíduos agroindustriais, tais como: rejeitos de cascas de banana, mamona, e resíduos como quitosana, bagaço de cana-deaçúcar (PELIZER, L.H.; PONTIERI, M.H.; MORAES, 2007). Sobretudo, dentre tantos resíduos agroindustriais, tem-se o resíduo da extração de corante de urucum ainda não explorado.

A Bixa orellana, pertencente à família das Bixaceas, popularmente conhecido como urucuzeiro é uma planta nativa da América Central e do Sul. O fruto do urucuzeiro, o urucum é uma antiga e conhecida fonte de corante natural amplamente utilizado em indústria de alimentos, em indústrias têxteis, em cosméticos (FRANCO, 2008; OLIVEIRA, 2005; SHAHID-UL-ISLAM; RATHER; MOHAMMAD, 2015). O Brasil é um dos maiores produtores e exportadores de corante extraído de sementes de urucum, sendo responsável por 57\% da produção mundial (ANSELMO et al., 2008; MANTOVANI et al., 2013). A literatura também reporta atividade antioxidante, antimicrobiana, benefícios farmacológicos e terapêuticos de compostos presentes nas sementes de urucum (ABAYOMI et al., 2014). As sementes de urucum são revestidas por uma camada resinosa de cor avermelhada, caracterizada por conter carotenoides. O principal carotenoide presente é a bixina $\left(\mathrm{C}_{25} \mathrm{H}_{30} \mathrm{O}_{4}\right)$, esta representa $80 \%$ dos carotenoides totais. A norbixina $\left(\mathrm{C}_{24} \mathrm{H}_{28} \mathrm{O}_{4}\right)$ pode ser encontrada naturalmente nas sementes, além de criptoxantina, luteína, zeaxantina em menores teores (MERCADANTE; PFANDER, 1998; PRABHAKARA RAO et al., 2005; TIRIMANNA, 1981). Os pigmentos representam menos de $6 \%$ do peso total das sementes de urucum. Logo o processo de extração do corante gera de 94 a 98\% de resíduos, atualmente descartados pela indústria ou incorporados a rações animais (MORAES et al., 2008). Segundo Tonani et al., (2000), a composição química do resíduo da extração de corante de urucum pode ser considerada equivalente ao farelo de trigo, por apresentar teores semelhantes especialmente de fibra e proteína bruta. Neste mesmo resíduo também há amido (cerca de 11,5-30,4\%) (BRITO et al., 2015; VALÉRIO et al., 2015).

Desta maneira, por ser o resíduo da extração de corante de urucum, um resíduo rico em amido, proteínas, fibras, compostos ativos e por ainda não ter sido explorado no desenvolvimento de filmes, propomos neste trabalho o estudo e valorização deste resíduo agroindustrial como matéria prima para a elaboração de filmes biodegradáveis ativos. 


\section{OBJETIVO GERAL}

Este trabalho tem como objetivo principal avaliar o potencial de aproveitamento do resíduo da extração de corante de urucum na produção de filmes biodegradáveis bioativos.

\section{OBJETIVOS ESPECÍFICOS}

- Caracterizar o resíduo da extração de corante de urucum.

- Extrair e caracterizar o material rico em amido a partir do resíduo da extração de corante de urucum por métodos de moagem em água (WS), moagem em pH ácido (AS) e em moagem meio alcalino (KS).

- Determinar as melhores condições para elaboração de filmes de farinha de urucum WS, AS e KS em diferentes valores de $\mathrm{pH}(5,7,9)$ e tempo de aquecimento (1h, 2h, 3h, 4h). Elaborar os filmes nas melhores condições e caracterizá-los em função a suas propriedades mecânicas e funcionais.

- Determinar a atividade antioxidante dos filmes de farinhas de urucum (WS, AS e KS) como também avaliar a atividade antimicrobiana do extrato da semente de urucum e de filmes de farinha WS, AS e KS contra bactérias e fungos filamentosos. 


\section{Referências Bibliográficas}

ABAYOMI, M. et al. In vitro antioxidant activity of Bixa orellana (Annatto) seed extract. J Appl Pharm Sci, v. 4, p. 101-6, 2014.

ALVES, M. M. T. R. Embalagens Biodegradáveis. Instituto ed. Lisboa-Portugal: INSTITUTO PIAGET, 2003.

ANSELMO, G. et al. Comportamento higroscópico do extrato seco de urucum (Bixa Orellana L). Ciência e Agrotecnologia, v. 32, n. 6, p. 1888-1892, dez. 2008.

AZEREDO, H. M. C. et al. Nanocomposite Edible Films from Mango Puree Reinforced with Cellulose Nanofibers. Journal of Food Science, v. 74, n. 5, p. N31-N35, jun. 2009.

BRITO, J. G. DE et al. Armazenamento de grãos residuais de urucum sob atmosfera controlada. Rev. bras. eng. agríc. ambient., v. 19, 2015.

CAMPOS, C. DA S. Plásticos : Tendências e Perspetivas. Disponível em:

$<$ https://reviplast.wordpress.com/2016/07/04/plsticos-tendncias-e-perspetivas/>.

CARR, L. G. ET AL. Influência da adição de caulim e CaCO3 nas propriedades mecânicas das espumas de amido. Congresso Brasileiro de Engenharia e Ciências dos materiais, CBECiMat, Foz do Iguaçu. Anais, 2006.

DOI \& FUKUDA. Biodegradable plastics and polymers. Amsterdam: Elsevier Ltd, 1994.

FRANCO, C. F. O. Corantes naturais de urucum (Bixa orellana L.) no tratamento da hiperlipidemia em animais e câncer em animais. [s.l.] Universidade Federal de Viçosa, 2008.

HUANG, S. J.; EDELMAN, P. Degradable Polymers: Principles and Applications. 2 Edition ed. London: ., 1995.

JACOMETTI, G. A. et al. The physicochemical properties of fibrous residues from the agro industry. LWT - Food Science and Technology, v. 62, n. 1, p. 138-143, jun. 2015.

KAYA, S.; MASKAN, A. Water vapor permeability of pestil (a fruit leather) made from boiled grape juice with starch. Journal of Food Engineering, v. 57, n. 3, p. 295-299, maio 2003.

LEÃO, A. L.; TAN, I. H. Potential of municipal solid waste (MSW) as a source of energy in São Paulo: its impact on CO2 balance. Biomass and Bioenergy, v. 14, n. 1, p. 83-89, mar. 1998.

LEE, S. Y.; CHOI, J. Effect of fermentation performance on the economics of poly(3hydroxybutyrate) production byAlcaligenes latus. Polymer Degradation and Stability, v. 59, n. 1-3, p. 387-393, jan. 1998.

MANIGLIA, B. C. et al. Development of bioactive edible film from turmeric dye solvent extraction residue. LWT - Food Science and Technology, v. 56, n. 2, p. 269-277, maio 2014.

MANIGLIA, B. C. et al. Turmeric dye extraction residue for use in bioactive film production: Optimization of turmeric film plasticized with glycerol. LWT - Food Science and Technology, v. 64, n. 2, p. 1187-1195, dez. 2015.

MANTOVANI, N. C. et al. Avaliação de genótipos de urucum (Bixa orellana L.) por meio da caracterização morfológica de frutos, produtividade de sementes e teor de bixina. Ciência 
Florestal, v. 23, n. 2, jun. 2013.

MERCADANTE, A. Z. .; PFANDER, H. Carotenoids from annatto: a review. Recent Research Developments in Agriculture and Food Chemistry., v. 2, n. 1, p. 79-91, 1998.

MORAES, A. S. et al. Balanço Nitrogenado de caprinos alimentados com dietas contendo subproduto de urucum (Bixa orellana L.). V Congresso Nordestino de Produção Animal. Anais. Anais...Aracaju: 2008

OLIVEIRA, J. S. Caracterização, extração e purificação por cromatografia de compostos de urucum (Bixa orellana L.). [s.1.] Universidade Federal de Santa Catarina, 2005.

PELIZER, L.H.; PONTIERI, M.H.; MORAES, I. O. Utilização de Resíduos AgroIndustriais em Processos Biotecnológicos como Perspectiva de Redução do Impacto Ambiental. Journal of Technology Management \& Innovation, v. 2, p. 118-127, 2007.

PHILP, J. C.; RITCHIE, R. J.; GUY, K. Biobased plastics in a bioeconomy. Trends in Biotechnology, v. 31, n. 2, p. 65-67, fev. 2013.

PRABHAKARA RAO, P. G. et al. Effect of processing conditions on the stability of annatto (Bixa orellana L.) dye incorporated into some foods. LWT - Food Science and Technology, v. 38, n. 7, p. 779-784, nov. 2005.

ROSA, D. . et al. The use of roughness for evaluating the biodegradation of poly- $\beta$ (hydroxybutyrate) and poly- $\beta$-(hydroxybutyrate-co- $\beta$-valerate). Polymer Testing, v. 23, n. 1, p. 3-8, fev. 2004.

SHAHID-UL-ISLAM; RATHER, L. J.; MOHAMMAD, F. Phytochemistry, biological activities and potential of annatto in natural colorant production for industrial applications - A review. Journal of Advanced Research, v. 7, n. 3, p. 499-514, 2015.

TIRIMANNA, A. S. L. Study of the carotenoid pigments of Bixa orellana L. Seeds by thin layer chromatography. Mikrochimica Acta, v. 76, n. 1-2, p. 11-16, jan. 1981.

TONANI, F. L. et al. Avaliação nutricional do resíduo de urucum (Bixa orellana L.), após a extração do corante. ARS Veterinária., v. 16, n. 2, p. 118-121, 2000.

VALÉRIO, M. A. et al. Annatto seed residue (Bixa orellana L.): nutritional quality. Food Science and Technology (Campinas), v. 35, n. 2, p. 326-330, jun. 2015. 
Capítulo 1. REVISÃO BIBLIOGRÁFICA 


\subsection{O urucum (Bixa orellana)}

O urucuzeiro, cujo fruto é o urucum, pertence à família Bixaceae e ao gênero Bixa (FRANCO et al., 2002). São conhecidas diversas espécies tais, como: arborea, excelsa, platycarpa, urucurana e orellana (MOREIRA et al., 2015). A Bixa orellana, nativa da América Tropical, é a espécie mais cultivada e explorada economicamente (GIULIANO; ROSATI; BRAMLEY, 2003). Pode-se encontrar o urucuzeiro, com vasta sinonímia: Achiote, no México; Bija no Peru; Urucu, na Bolívia; Arnoto, em Ceilão; Ditaque e Kifasu, em Angola; Orleans Laum, na Alemanha; Roucou, Rocouyer, na França, Annatto, na Inglaterra e em tantos outros países (FRANCO et al., 2002).

A Bixa orellana é um arbusto que pode atingir de 2 a 9 metros de altura com sistema radicular do tipo pivotante, onde há um eixo principal, a partir do qual brotam, lateralmente, ramificações secundárias e terciárias. Apresenta caule lenhoso, de onde partem ramos que formam uma copa bem frondosa, rica em folhas verdes, como apresentado na Figura 1.1 (A), com flores grandes de coloração branca ou rósea, as quais são emitidas durante todo o ano com maior intensidadeem meses antecedentes a Junho/Julho e Novembro/Dezembro, definindo as safras. A colheita do urucum é feita 120 dias após a abertura da flor. Os frutos do urucuzeiro são cápsulas ou cachopas ovóides ricas em sementes. Um fruto bem desenvolvido pode fornecer, em média, de 40 a 60 sementes, como mostrado na Figura 1.1 (B) (FRANCO et al., 2002). As sementes têm formato obovóides e são cobertas por uma camada resinosa vermelha (BARROSO, 1978; CORREA, 1978; LORENZI, 1998). Deste pericarpo, camada que envolve as sementes, é possível extrair corantes naturais, constituídos por vários carotenoides, predominando a bixina (FRANCO et al., 2002; MANTOVANI et al., 2013). O processo de extração de corante natural a partir das sementes de urucum gera o resíduo apresentado na Figura 1.1 (C). 
Figura 1.1 - (A) Foto do urucuzeiro (Bixa orellana), do (B) fruto urucum aberto com exposição das sementes e do (C) resíduo da extração do corante de urucum
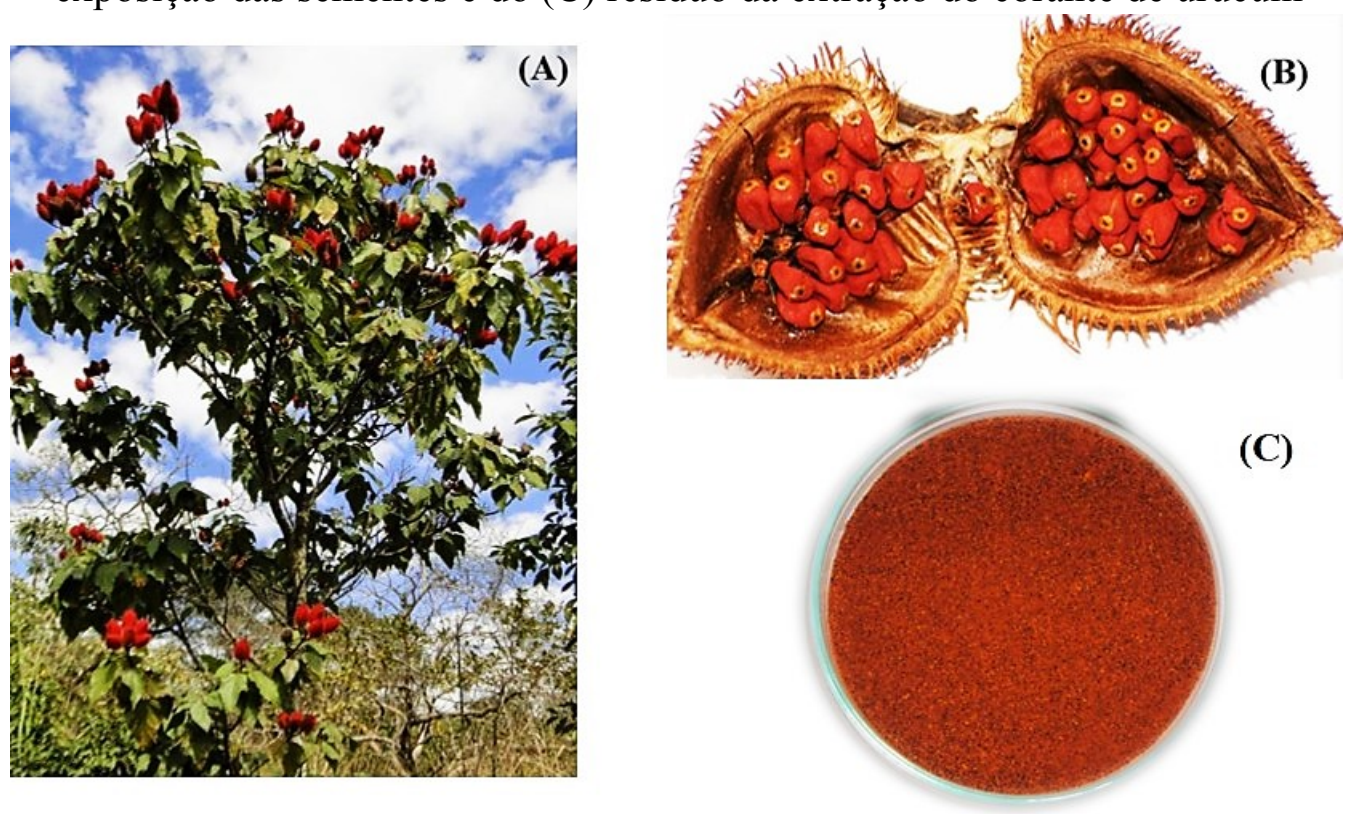

Fonte: Fotografias da autora, registradas em Nepomuceno-MG.

Os indígenas utilizavam o urucum para colorir objetos de cerâmica, colorir a pele para rituais religiosos e guerras, também como proteção aos raios ultravioletas e picadas de insetos, na tintura de tecidos, assim como na formulação de uma bebida à base de cacau (CONSTANT; STRINGHETA; SANDI, 2002; GIULIANO; ROSATI; BRAMLEY, 2003; OLIVEIRA, 2005). O urucum também tem sido utilizado como condimento em pratos caseiros desde aquela época (OCAMPO, 1983).

A cultura do urucum tem aumentado por ser uma das maiores fontes de corantes naturais, pois o uso dos corantes sintéticos tem sido proibido em países como Estados Unidos, Japão e alguns países da Europa desde a década de 90 devido a suas características tóxicas e efeitos cancerígenos.

O Brasil é responsável por $57 \%$ da produção mundial de urucum segundo a Sociedade Nacional de Agricultura. Em 2014, a produção de urucum no Brasil foi de 12.512 toneladas. A região mais produtora é a Norte com 3.658 toneladas, seguida pela região Nordeste com 2.306 toneladas, Sudeste com 1.378 toneladas, Sul com 1.124 toneladas e Centro-Oeste com 263 toneladas. Os estados que se destacam são Bahia com 4.870 toneladas, Rio de Janeiro com 3.452 toneladas e Rondônia com 1.969 toneladas (IBGE, 2014). Outros produtores mundiais são Peru (6.000 toneladas), Costa do Marfim e Gana (5.000 toneladas), Quênia (2.000 toneladas), Guatemala (1.500 toneladas), República Dominicana (900 toneladas), Bolívia (500 toneladas), Equador (400 toneladas), Índia (300 toneladas) e México (200 toneladas). 
Da produção nacional de urucum, 60\% são destinados à fabricação de "colorau", $30 \%$ para produção de corantes e $10 \%$ destinados à exportação. De acordo com a resolução CNNPA n¹2, de 1978 da Anvisa, o colorífico ou colorau é definido como um produto constituído pela mistura de farinha de mandioca ou de fubá, com urucum (Bixa orellana) em pó ou extrato oleoso de urucum, adicionado ou não de sal e de óleos comestíveis (BRASIL, 1978). O colorau é um condimento comum na América Latina, mais de 140 milhões de brasileiros utilizam e seu consumo não é prejudicial à saúde, pois reduz o colesterol total e os triglicerídeos, além de possuir altos teores de proteínas e aminoácidos essenciais (FRANCO, 2008). O corante é o produto extraído do arilo das sementes de urucum, sendo constituído por bixina, norbixina e outros em menores proporções. Estes compostos são os responsáveis pelo poder corante, amarelo-avermelhado de extratos utilizados na indústria de alimentos, farmacêutica e cosméticos (GIULIANO; ROSATI; BRAMLEY, 2003).

\subsection{Bixina e norbixina}

A bixina $\left(\mathrm{C}_{25} \mathrm{H}_{30} \mathrm{O}_{4}\right)$ representa $80 \%$ dos carotenoides totais lipossolúveis nas sementes, já a norbixina $\left(\mathrm{C}_{24} \mathrm{H}_{28} \mathrm{O}_{4}\right)$ é encontrada naturalmente em pequenas quantidades nas sementes e outros menos importantes, como criptoxantina, luteína, zeaxantina (MERCADANTE; STECK; PFANDER, 1999; PRABHAKARA RAO et al., 2005; TIRIMANNA, 1981).

A bixina $\left(\mathrm{C}_{25} \mathrm{H}_{30} \mathrm{O}_{4}\right)$ apresenta um ácido carboxílico e um éster metílico nas extremidades da cadeia, como mostrado na Figura 1.2. A presença do éster metílico confere a bixina, características lipossolúveis. A hidrólise do grupo metil éster da bixina, produz a norbixina $\left(\mathrm{C}_{24} \mathrm{H}_{28} \mathrm{O}_{4}\right)$ (Figura 1.2), um ácido dicarboxílico de maior hidrossolubilidade em razão da presença do grupamento carboxila, sítio de interações com moléculas de água (LIMA et al., 2001). 
Figura 1.2 - Fórmulas estruturais da bixina e norbixina<smiles>COC(=O)/C=C/C(C)=C/C=C/C(C)=C/C=C/C=C(C)/C=C/C=C(C)/C=C/C(=O)O</smiles><smiles>CC(/C=C/C=C/C=C(C)/C=C/C(=O)O)=C\C=C\C=C(C)\C=C\C(=O)O</smiles>

Fonte: Tocchini e Mercadante (2001).

Soluções alcalinas como de hidróxido de sódio ou hidróxido de potássio, transformam a bixina em um sal de norbixina, como apresentado na Figura 1.3, que é comercializado nessa forma, permitindo a utilização em alimentos contendo baixos teores de óleo. Esta transformação amplia o uso dos corantes de urucum.

Figura 1.3 - Reações químicas para obtenção de corante norbixina de urucum utilizando soluções alcalinas

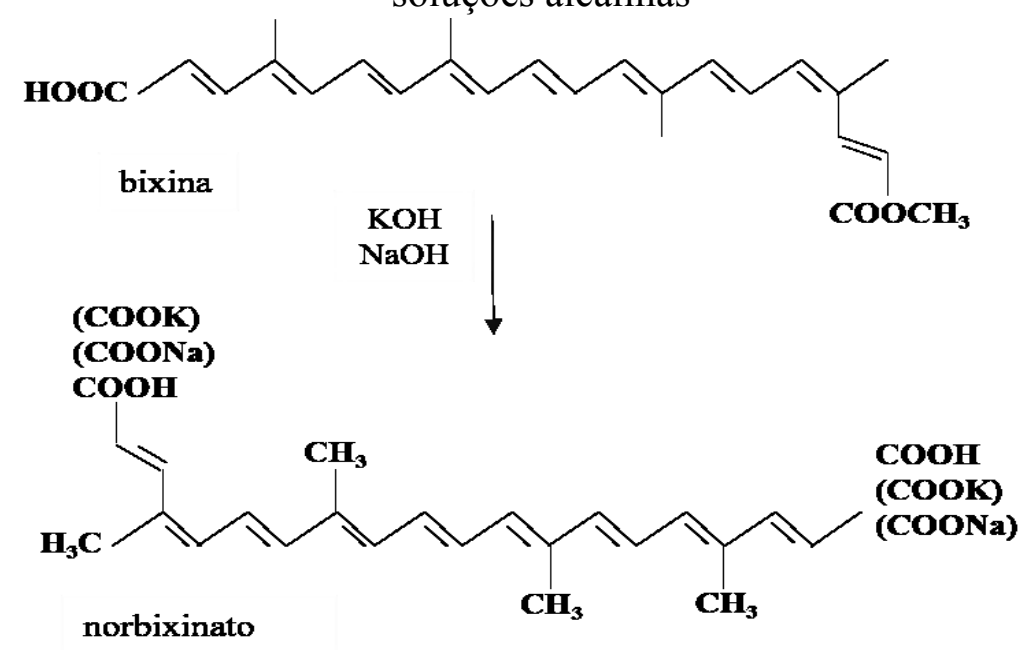

$$
\mathrm{H}+\downarrow \uparrow \begin{array}{r}
\mathrm{KOH} \\
\mathrm{NaOH}
\end{array}
$$

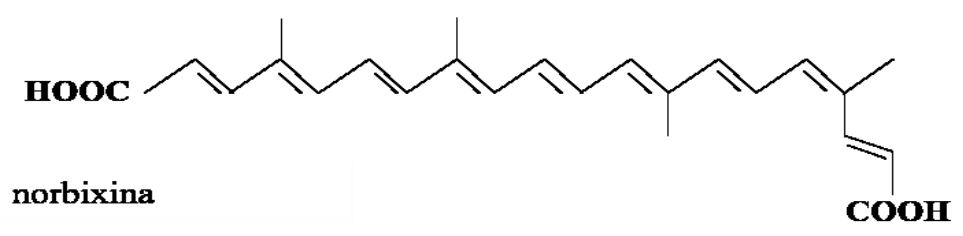

Fonte: Silva (2007). 
Bixina e norbixina podem sofrer isomerização frente à instabilidade das instaurações presentes na molécula. Estão presentes naturalmente, os isômeros cis, tanto da bixina quanto da norbixina e são convertidos na forma trans, mais estável, durante o processo de extração a altas temperaturas (Figura 1.4). A cis-bixina tem coloração alaranjada, enquanto a trans-bixina proporciona coloração vermelha (SATYANARAYANA et al., 2006).

Figura 1.4 - Reações de isomerização dos pigmentos de urucum

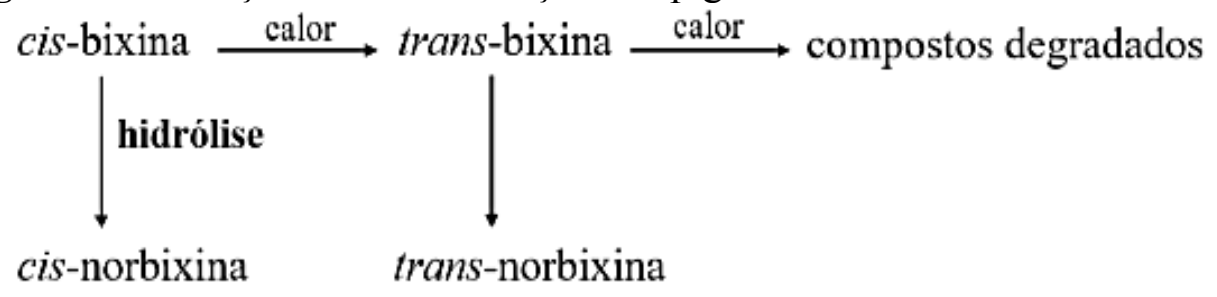

Fonte: HENRY (1996).

As diferenças estruturais entre bixina e norbixina estão relacionadas à polaridade, solubilidade, coloração e, por consequência, determinam singulares aplicações tecnológicas do corante de urucum (GARCIA et al., 2012). A bixina, pigmento lipossolúvel, devido a presença de um éster metílico na molécula é usada em alimentos como margarinas, cremes, sorvetes, queijos (VALÉRIO et al., 2015). A norbixina, devido a presença do grupamento carboxila tem maior hidrossolubilidade sendo então, utilizada principalmente na produção de bebidas e molhos (GARCIA et al., 2012).

A bixina e norbixina podem ser extraídas de sementes de urucum desidratadas por extração indireta com solventes, extração direta usando soluções alcalinas aquosas e extração direta com óleo (SANTOS et al., 2014). A extração indireta produz extratos que contêm principalmente cis-bixina $\left(\mathrm{C}_{25} \mathrm{H}_{30} \mathrm{O}_{4}\right)$ e quantidades menores de trans-bixina e cis-norbixina (RIOS; MERCADANTE; BORSARELLI, 2007; SCOTTER et al., 1998). A extração em óleo produz bixina (KANG et al., 2010; SCOTTER, 2009). A extração em solução alcalina produz norbixina (CAMPBELL; BOOGERS; DRAKE, 2014).

O vermelho intenso indica a presença de bixina concentrada, enquanto a coloração amarela indica predominância de norbixina. A bixina é um carotenoide com altas propriedades antioxidantes, pois apresenta um sistema de ligação dupla conjugada que constituí um excelente captor de radicais livres (KIOKIAS, 2003; KRINSKY, 1989). 
Os compostos presentes nas sementes de urucum têm atividade antioxidante e antimicrobiana, além de benefícios farmacológicos e terapêuticos. A atividade antioxidante do extrato de semente de Bixa Orellana pode ser devido à presença de taninos e flavonóides (ABAYOMI et al., 2014). Alguns autores também relatam que o óleo de sementes de urucum contém vitamina $\mathrm{E}$, classificada como tocoferóis $(\alpha, \beta, \gamma$ e $\delta)$ ou tocotrienóis $(\alpha, \beta, \gamma$ e $\delta)$, compostos antioxidantes e anticancerígenos (ALBUQUERQUE; MEIRELES, 2012; PIERPAOLI et al., 2013; SILVA et al., 2015; TAHAM; CABRAL; BARROZO, 2015).

Mercadante; Steck; Pfander, (1999); Pino; Correa, (2003); Sylvester; Shah, (2005) relataram que a bixina inibiu fortemente a auto-oxidação de triglicérideos de óleo. Kiokias (2003) verificou que a norbixina inibiu a deterioração oxidativa de azeite a granel.

Os extratos de sementes de urucum também mostram amplo espectro antibacteriano contra Bacillus subtilis, Staphylococcus aureus, Streptococcus pyogenes, Salmonella typhi, Pseudomonas aeruginosa, Escherichia coli e Candida albicans. A atividade antimicrobiana é proporcional ao teor de bixina uma vez que os principais compostos antimicrobianos são os carotenoides (FLEISCHER et al., 2003; GALINDO-CUSPINERA; MAJOLO; CARVALHO; WIEST, 2013). Braga et al., (2007) e Rojas et al., (2006) relataram atividade antimicrobiana de extratos de Bixa orellana na conservação de alimentos.

Uma vez que a União Européia autorizou a utilização de corante de urucum, ao qual é atribuído o número $\mathrm{E}$ de $\mathrm{E} 160 \mathrm{~b}$, indústrias de alimentos, cosméticos, indústrias têxteis e de fármacos começaram a utilizá-lo como aditivo, estimulando a extração industrial do corante de urucum (SHAHID-UL-ISLAM; RATHER; MOHAMMAD, 2015). A bixina, pigmento de maior interesse para extração e produção de corante natural representa menos de $6 \%$ do peso total da semente de urucum, logo o processo de extração do corante de urucum tem gerado um considerável resíduo industrial, que representa de 94 a $98 \%$ da matéria-prima processada (MORAES et al., 2008). A Tabela 1 apresenta dados da literatura sobre a composição centesimal do resíduo da extração de corante de urucum. Destaca-se a presença do amido (11,5 a $30,42 \%)$, fibras $(28,48 \%)$, proteínas $(11,50 \%)$ e cinzas $(5,22 \%)$. 
Tabela 1 - Composição centesimal do resíduo da extração de corante de urucum

\begin{tabular}{ll}
\hline Componentes & $(\mathrm{g} / 100 \mathrm{~g}$ massa seca $)$ \\
\hline Umidade* & 6,75 \\
Linzas & 5,22 \\
Proteínas & 2,33 \\
Fibras & 28,48 \\
Carboidratos & 42,20 \\
Amido & $11,50 \mathrm{a} 30,42$ \\
*: Umidade, expressa em base úmida, (g/100 g amostra total)
\end{tabular}

Fonte: Valério et al. (2015); Brito, Queiroz, Figueirêdo e Oliveira (2015a)

Devido a esta composição química, vários autores tem sugerido o uso deste resíduo como complemento em ração de suínos (UTIYAMA; MIYADA; FIGUEIREDO, 2002) e frangos (SILVA et al., 2005) ou como agente corante para gema de ovos (BRAZ et al., 2007). Entretanto, este resíduo apresenta importante teor de amido (de 11, 5 a 30,42\%) (BRITO et al., 2015; VALÉRIO et al., 2015) que pode ser utilizado como aditivo na indústria de alimentos ou como matéria-prima para a produção de embalagens biodegradáveis.

\subsection{Amido}

Os grânulos de amido são constituídos por dois polissacarídeos, amilose e amilopectina (HIZUKURI, 1986). A amilose é um homopolímero linear constituído por 300 a 1000 unidades de $\alpha$-D-glicopiranose, unidas por ligações $\alpha-1,4$ glicosídicas (Figura 1.5A) (BULÉON et al., 1998) (Figuras 1.5-1.6A). A amilopectina apresenta estrutura ramificada, constituída por cadeias lineares de 20-30 unidades de $\alpha$-D-glicose unidas por ligações glicosídicas $\alpha-1,4$ e $\alpha$ 1,6 (FRENCH, 1984; LINEBACK, 1984) (Figuras 1.5-1.6B). As diferenças estruturais entre amilose e amilopectina, as proporções destas, assim como a fonte de origem, tamanho e forma do grânulo irão influenciar as propriedades funcionais do amido, como sua capacidade espessante, gelificante e nos processos de gelatinização e retrogradação, assim como nas 
propriedades mecânicas e funcionais dos filmes biodegradáveis a base de amido (HIZUKURI, 1986).

Figura 1.5 - Estrutura representativa do amido

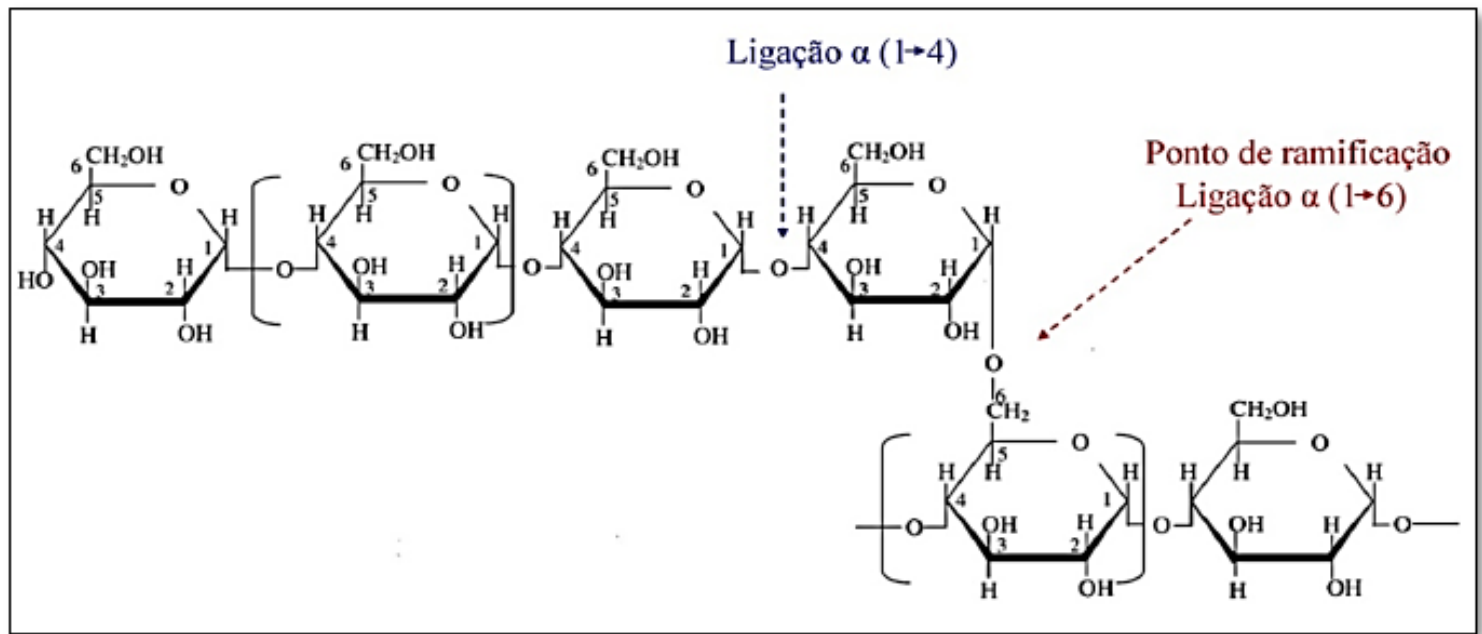

Fonte: Baseado na estrutura apresentada por Tester, Karkalas e QI (2004).

Figura 1.6 - Estrutura da (A) amilose e (B) amilopectina

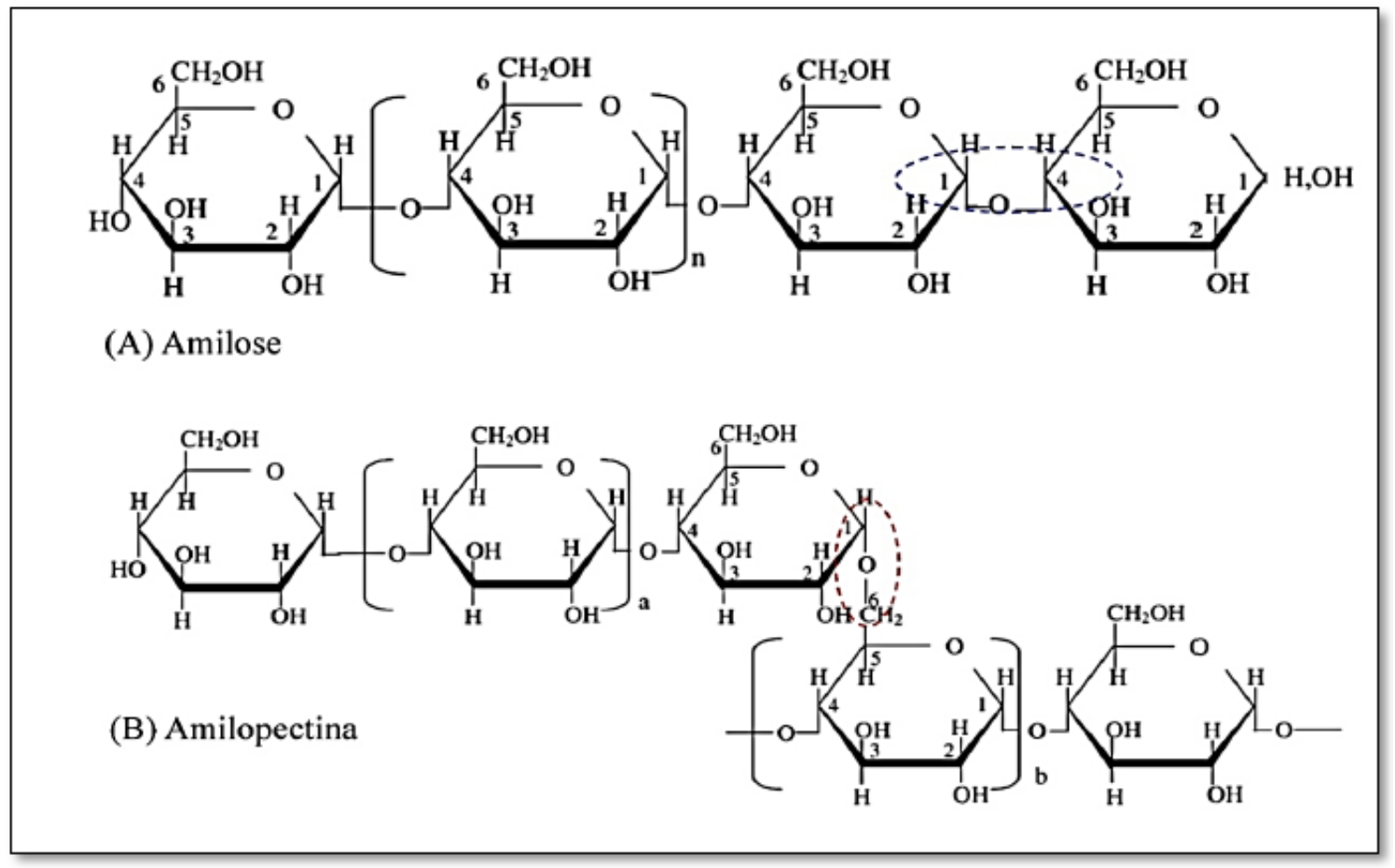

Fonte: Adaptado de Tester, Karkalas e QI (2004).

Os amidos nativos têm estrutura semi-cristalina, contendo regiões cristalinas e não cristalinas em camadas alternadas formadas por ligação de hidrogênio entre as estruturas de amilose e amilopectina (JENKINS, D.; RICHARD, M. G.; DAIGGER, 1993). A dispersão de amido exige aquecimento em água ou outro solvente, logo a estrutura cristalina do amido é 
perturbada e então, favorece que as moléculas de solvente interajam com os grupos hidroxila da amilose e da amilopectina, levando a solubilização parcial de amido (HOOVER, 2001). Assim, quando os grânulos se incham em presença de água, abrem-se, incham e hidratam para iniciar o processo de gelatinização ou perda de ordenamento molecular e granular (KRAMER, 2009). A estrutura do grânulo de amido destruída durante o aquecimento forma um gel. No entanto, por não estar em equilíbrio termodinâmico, sua estrutura cristalina pode ser retomada com o resfriamento. A capacidade do grânulo de amido reordenar a sua estrutura após o processo de gelatinização, é conhecido com retrogradação (MOORTHY; LARSSON; ELIASSON, 2008).

O amido é utilizado amplamente na indústria de alimentos, farmacêutica, de papel e polímero, cosmética (OTHMAN; AL-ASSAF; HASSAN, 2010) por ser uma fonte renovável, facilidade de acesso, baixo custo e propriedades físico-químicas interessantes como sua biocompatibilidade, biodegradabilidade e não toxicidade (YULIANA et al., 2012).

$\mathrm{O}$ isolamento de amido a partir de resíduos agroindustriais torna-se uma alternativa sustentável e interessante, uma vez que as fontes de amido mais exploradas, como batata, mandioca, milho, arroz e trigo são utilizadas para alimentação humana. Por métodos de separação alcalina, ácida ou enzimática o amido pode ser isolado (ARVANITOYANNIS; KASSAVETI, 2009). Como a maioria dos métodos de isolamento afeta as propriedades do material final, é essencial identificar a técnica de isolamento mais adequada em termos de pureza, rendimento e propriedades do amido (CORREIA; BEIRÃO-DA-COSTA, 2012). A extração comercial do amido é feita por moagem ou ralação, separação da fibra e suspensão de amido em água, centrifugação, purificação, desidratação e secagem (AGAMA-ACEVEDO et al., 2014; SANTOS, 2013) No entanto, alguns tipos de amidos exigem novas etapas no processo de extração.

Correia et al. (2013) observaram que o método alcalino para isolamento de amido de castanhas portuguesas proporcionou maior rendimento de extração de amido, em comparação com o método enzimático. Pálacios-Fonseca et al. (2013) observaram que métodos de isolamento de amido de milho em meio ácido ou alcalino influenciaram na cristalinidade, teor de amilose e entalpia dos grânulos de amido. O método alcalino produziu grânulos de amido com menor teor de lipídeo e proteína. Belhadi, Djabali, Souilah, Yousfi, \& Nadjemi (2013), avaliaram o isolamento de amido de sorgo e observaram que o método alcalino confere um maior rendimento de extração, já o método ácido obteve maior pureza. Sun, Chu, Xiong, \& Si 
(2015) isolaram amido de ervilha por três métodos: moagem seca e extração em meio ácido, alcalino e enzimático. O amido isolado pelo método alcalino apresentou maior viscosidade e maior entalpia. Maniglia \& Tapia-Blácido (2016) avaliaram o isolamento de amido de babaçu por maceração alcalina e em água, sendo que o método alcalino proporcionou maior rendimento, pureza, menor quantidade de amilose, grânulos de amido mais aglomerados, maior estabilidade térmica, alto poder de solubilidade e inchamento. Mas, a maceração em água permitiu obter menor perda de compostos fenólicos totais. Estrada-León et al., (2016) verificaram o isolamento de amido das sementes de parota por três métodos: maceração em bisulfito de sódio, água e ácido. A extração com bisulfito de sódio apresentou maior rendimento, pureza e menor quantidade de amilose. Entretanto, o isolamento usando o método de maceração em água destilada e ácido mostraram melhor poder de inchamento e solubilidade dos amidos.

\subsection{Filmes biodegradáveis}

O interesse em desenvolver filmes biodegradáveis a partir de fontes renováveis tem sido crescente, devido às preocupações ambientais quanto ao crescente uso e descarte de embalagens não renováveis aliado às oportunidades para criação de um mercado com foco em aproveitamento de resíduos agroindustriais como matérias-primas formadoras de filmes (HENRIQUE; CEREDA; SARMENTO, 2008).

O filme biodegradável pode ser degradado em cerca de 20 dias, já o filme tradicional pode demorar até 500 anos para degradação completa (ALVES, 2003; CARR, 2006). A degradação ocorre por ação enzimática de organismos vivos, como bactérias, leveduras, fungos resultando em produtos finais do processo, como o $\mathrm{CO}_{2}, \mathrm{H}_{2} \mathrm{O}$ e biomassa sob condições aeróbias e hidrocarbonetos, metano e biomassa em condições anaeróbicas (DOI \& FUKUDA, 1994; OJEDA, 2013).

Os filmes biodegradáveis são filmes finos, formados a partir de biopolímeros como proteínas (caseína, proteínas do soro do leite, proteína do milho (zeina), proteína do trigo (glúten), colágeno, gelatina), polissacarídeos e seus derivados (celulose, quitosana, amido, alginatos, pectinas, gomas), os quais são capazes de formar uma rede tridimensional semi- rígida, que retém o solvente (GUILBERT, 1986). A rede tridimensional é formada pelas associações inter e intramoleculares ou ligações cruzadas de cadeias dos polímeros (THARANATHAN, 2003). A coesão depende da estrutura do polímero, do processo de fabricação, de fatores físicos e da presença de plastificante (GONTARD; GUILBERT; CUQ, 1993). 
Para formação do filme são também necessários solvente, agente plastificante e agente ajustador de pH (CUQ; GONTARD; GUILBERT, 1997). Os solventes comumente utilizados são água, etanol ou a combinação de ambos (KESTER, J. J. AND FENNEMA, 1986). Os plastificantes empregados são geralmente, compostos hidrofílicos como os polióis: glicerol, sorbitol. Estes se acoplam facilmente entre as cadeias poliméricas devido à habilidade em reduzir as pontes de hidrogênio entre cadeias, causando um aumento do volume livre ou da mobilidade molecular do polímero (BODMEIER, R; PAERATAKUL, 1997) contribuindo na redução da fragilidade do filme, aumentando a flexibilidade e extensibilidade (MALI et al., 2002). Para a formação de um filme homogêneo, ajustes de pH são necessários para maior solubilidade da macromolécula seja atingida (BATISTA, 2004). Os ajustadores de pH mais utilizados em filmes biodegradáveis são ácido acético glacial, ácido ascórbico, hidróxido de sódio (KESTER, J. J. AND FENNEMA, 1986; (GONTARD; GUILBERT; CUQ, 1992). Além destes compostos, podem ser adicionados também outros, como agentes antimicrobianos, antioxidantes, corantes, lipídeos, vitaminas (KROCHTA; DE MULDER-JOHNSTON, 1996).

Os filmes elaborados pelo método casting (GONTARD; GUILBERT; CUQ, 1992) baseia-se em uma primeira etapa de solubilização do polímero em solvente, na sequência adiciona-se o plastificante e aditivos para melhorar as propriedades mecânicas e funcionais do filme. Na segunda etapa, a solução filmogênica é depositada sobre um molde não adesivo e em seguida, submetida a secagem em estufa formando o filme (VICENTINO et al., 2011).

Os filmes biodegradáveis podem ser aplicados sobre alimentos, neste caso servirá como barreira a elementos externos e, consequentemente, protege o produto embalado de danos físicos e biológicos, com extensão da vida de prateleira (HENRIQUE; CEREDA; SARMENTO, 2008). Dependendo da composição dos filmes, estes podem ser comestíveis.

\subsection{Filmes biodegradáveis à base de farinha e/ou resíduos agroindustriais}

Os filmes biodegradáveis podem ser produzidos a partir de blendas naturais, que consistem de misturas naturais (carboidratos, proteínas, lipídeos e fibras) obtidas na forma de farinha a partir de matérias-primas de origem vegetal, tais como cereais, tubérculos, rizomas e até mesmo resíduos agroindustriais resultantes de processamento da fonte vegetal.

Os filmes elaborados a partir de farinhas tendem a diminuir deficiências em relação a baixa barreira ao vapor de água e baixa resistência mecânica e alongamento típicos de filmes produzidos de um único biopolímero (MONTAÑO-LEYVA, 2003). Contudo, as propriedades 
dos filmes de farinha dependerão do tipo da interação formada pela mistura de biopolímeros (amido, proteína, fibras e pelo lipídeo), e também em relação à distribuição dessas interações dentro da matriz do filme, do balanço das interações hidrofílicas e hidrofóbicas, assim como da concentração de cada componente dentro do filme (ANDRADE-MAHECHA; TAPIABLÁCIDO; MENEGALLI, 2012; TAPIA-BLÁCIDO et al., 2007).

A literatura reporta diversos trabalhos de elaboração de filmes biodegradáveis à base de farinhas.

Tapia-Blácido, Sobral e Menegalli (2005), elaboraram filmes de farinha de amaranto. Os filmes de farinha de amaranto apresentaram coloração amarelada, moderada opacidade, alta flexibilidade e baixa resistência mecânica. No entanto, apresentaram menor permeabilidade ao oxigênio e a água que filmes de proteína e polissacarídeos.

Dias et al. (2010) elaboraram filmes de farinha e amido de arroz e notaram que ambos os filmes apresentaram estruturas compactas e com propriedades mecânicas similares. No entanto, a permeabilidade ao vapor de água dos filmes de farinha foi duas vezes superior à dos filmes de amido.

Andrade-Mahecha, Tápia-Blácido e Menegalli (2012), desenvolveram filmes de farinha de achira e obtiveram materiais com boas propriedades mecânicas, baixa permeabilidade ao vapor de água e solubilidade quando comparada a filmes elaborados com outras farinhas de tubérculos.

Pelissari et al. (2013) produziram filmes de farinha e amido de banana e notaram que os filmes de farinha foram menos resistentes e mais elongáveis, mais amarelados e porosos que os filmes de amido. O uso da farinha foi enfatizado pela redução de custo na produção, já que essa farinha é mais barata que amidos comerciais.

Salas-Valero, Tapia-Blácido e Menegalli, (2015) produziram filmes de farinha de canihua (cupi e illpa-inia). Os filmes apresentaram maior bloqueio à luz, menor solubilidade e permeabilidade ao vapor de água que filmes de polissacarídeos.

Daudt et al. (2016) produziram filmes de farinha e amido de pinhão. Filmes de farinha apresentaram maior permeabilidade ao vapor de água e opacidade, menor rigidez, tensão e elongação que os filmes de amido.

Vargas et al. (2017) produziram filmes de farinha de amido e farinha com amido de 
arroz vermelho. Os filmes de farinha de arroz vermelho apresentaram-se menos transparentes que os de cor vermelha e tiveram custo menor quando comparados aos filmes produzidos apenas de amido, apresentaram ótima atividade antioxidante.

É mais comum encontrar filmes produzidos de farinhas obtidas de fontes vegetais íntegras, como os trabalhos listados anteriormente. Estudos sobre elaboração de filmes biodegradáveis a partir de farinhas isoladas de resíduos agroindustriais são ainda em menor número na literatura.

Maniglia et al. (2015), produziram filmes de farinha de cúrcuma. Os autores observaram que os filmes elaborados a partir desta farinha, proveniente de um resíduo agroindustrial, apresentou além de alta resistência e baixa solubilidade, a presença de compostos ativos que lhe conferiram propriedade antioxidante.

Maniglia et al. (2017) produziram filmes de farinha e de amido de babaçu. Os filmes de farinha isolada a partir do resíduo agroindustrial de babaçu, mostraram-se menos resistentes mecanicamente, menos cristalino, mais opacos, mais flexíveis, mais hidrofílicos e mais permeáveis ao vapor de água do que os filmes de amido. Tanto os filmes de farinha quanto os filmes de amido de babaçu apresentaram boa atividade antioxidante.

\subsection{Filmes ativos}

As embalagens eram tradicionalmente desenvolvidas para conter e proteger o produto. Um requisito principal era a não interação, funcionavam então como uma barreira inerte. Essa ideia mudou e hoje é de grande interesse o desenvolvimento de embalagens ativas que apresentem interações desejáveis com o produto, aumentando ou monitorando sua vida-deprateleira (ALMEIDA, 2013).

Segundo Rooney (1995), as embalagens ativas exercem papel na preservação dos alimentos. E ainda, de acordo com Vermeiren, Devliegheree Debevere (2002), as embalagens ativas interagem com o alimento de maneira intencional, visando primordialmente à melhoria de suas características, alterando as condições dos produtos, aumentando sua vida de prateleira, segurança e qualidade ou até mesmo melhorando suas características sensoriais. As embalagens ativas exercem funções adicionais, como absorção de compostos que favorecem a deterioração, liberação de compostos que aumentam a vida-de-prateleira, monitoramento da vida-de-prateleira (HOTCHKISS, 1995). 
As embalagens ativas apresentam aplicações antimicrobianas, antioxidantes, aromatizantes, sequestradoras (absorvedoras de etileno, absorvedoras de umidade, oxigênio, odores, dióxido de carbono e luz ultravioleta) e emissoras (oxigênio e etileno) (SOARES et al., 2009; VERMEIREN et al., 1999).

A oxidação lipídica e crescimento microbiano são os principais fatores da degradação de alimentos como óleos, molhos, leite em pó integral, frutas, carnes, peixes. Uma estratégia para retardar essas possíveis degradações é a adição direta de antioxidantes e agente antimicrobiano em embalagens. Os compostos antioxidantes e antimicrobianos ficam em contato direto com a superfície do alimento, local que inicia o processo de degradação. Então, durante armazenamento ocorre a migração destes compostos para o alimento, o que resulta em menor teor de conservantes incorporados diretamente no alimento e aumentando a vida de prateleira dos alimentos embalados (COMA, 2013).

Os filmes ativos correspondem a esse tipo de embalagem ao interagir com o produto e proporcionar benefícios extras em relação aos filmes convencionais (BODAGHI et al., 2013).

Atualmente, diferentes estudos sobre a incorporação de agentes antimicrobianos e antioxidantes em diferentes matrizes filmogênicas têm sido estudados. A indústria de alimentos, utiliza aditivos de origem sintética como o butilhidroxitolueno (BHT), butilhidroxianisol (BHA), sais de sulfito, metabissulfito, ácido benzoico, óxido de etileno, nitratos, nitritos, ácido ascórbico e outros. Diante do crescente número de problemas de saúde associados à ingestão de conservantes sintéticos, a busca por conservantes de origem natural se intensificou(TYAGI et al., 2012). Há também recentes estudos com fontes renováveis que já apresentam a presença intrínseca de compostos ativos com funções antioxidantes/antimicrobiana associados a macromoléculas podendo ser utilizados como embalagem ativa para alimentos. Nas próximas seções 1.6.1 e 1.6.2 serão abordados os trabalhos reportados pela literatura sobre filmes antioxidantes e filmes antimicrobianos.

\subsubsection{Filmes com atividade antioxidante}

O desenvolvimento de embalagens biodegradáveis com ação antioxidante é de grande interesse para as indústrias de alimentos e sociedade, visto que as reações de degradação por oxidação são responsáveis pela deterioração dos alimentos, sendo a segunda maior causa, atrás 
da deterioração microbiana (NERÍN; TOVAR; SALAFRANCA, 2008).

A auto-oxidação é um mecanismo auto catalítico dos radicais livres, que podem ser gerados resultantes da ação de iniciadores, como a luz, temperatura ou íons metálicos. Consiste em 3 fases: iniciação, propagação e terminação. A reação de iniciação produz o radical alquil do ácido graxo, que por sua vez, reage com o oxigênio para formar radicais peróxidos na reação de propagação. Os radicais peróxidos reagem com ácidos graxos insaturados e formam hidroperóxidos, que posteriormente se decompõem para produzir compostos aromáticos voláteis que dão sabor indesejado e odor rançoso. A interação dos radicais alquil e peróxido, leva à formação de produtos como aldeídos, alcanos e dienos conjugado. A formação de aldeído tem sido relacionada diretamente com a mudança de cor e sabor (SAMPAIO et al., 2012).

Além do desenvolvimento de aromas rançosos, a deterioração oxidativa dos lipídios pode causar o branqueamento de alimentos devido à reação dos pigmentos, especialmente os carotenoides, com os intermediários reativos, chamados radicais livres, que são formados durante a oxidação lipídica. Os radicais livres também podem levar a uma redução da qualidade nutricional, por reagir com vitaminas, especialmente a vitamina $\mathrm{E}$, a qual se perde quando da sua ação como antioxidante no alimento.

Os antioxidantes são substâncias que retardam ou previnem a oxidação de substratos, tornando-os indisponíveis para formação de espécies oxidantes Ao inibir ou retardar a oxidação, os antioxidantes podem eliminar os radicais livres (atividade sequestrante), sendo neste caso descrito como antioxidante primário ou podem agir através de uma variedade de mecanismos, incluindo a ligação de íons metálicos, eliminação/seqüestro de oxigênio, conversão de hidroperóxidos em espécies não-radicais, absorção de radiação UV ou desativação de oxigênio singlete, sendo neste caso descrito antioxidantes secundários (HALLIWELL, B.; GUTTERIDGE, 1999).

Dentro do grupo de antioxidantes encontram-se as antocianinas, fenólicos, carotenoides, e os ácidos orgânicos, como o ácido ascórbico e outros.

O uso de filmes antioxidantes pode inibir processos oxidativos (ROCHA GARCIA, 2002). Neste contexto, as embalagens passivas têm sido transformadas em embalagens ativas pela adição de compostos com poder antioxidante.

Santana et al. (2012) avaliaram a eficácia da incorporação de diferentes concentrações do urucum como aditivo antioxidante em filmes biodegradáveis a base de quitosana e ainda 
sugeriu a aplicação deste filme em alimentos lipídicos, como óleos e gorduras, para evitar a oxidação desses produtos. López-Mata et al. (2015) também produziram filmes ativos de quitosana ao incorporar óleo de canela.

Li et al. (2014) produziram filme ativo antioxidante de gelatina ao incorporar antioxidantes naturais como extratos de chá verde, extratos de sementes de uvas e extratos de gengibre. Estes extratos são ricos em compostos fenólicos, flavonóides e carotenoides, sendo estes responsáveis pela atividade antioxidante.

Perazzo et al. (2014) produziram filme ativo de amido de mandioca ao incorporar a matriz extrato de chá verde, sendo este rico em polifenóis. Dantas et al. (2015) também produziram filmes ativos de amido de mandioca ao incorporar polpas de frutas tropicais (manga, acerola e seriguela) nesta matriz e embalar azeite de dendê observou efeito antioxidante. Pagno et al. (2016) também produziram filmes ativos de amido de mandioca incorporado com nanocapsúlas de bixina. Também foi verificada a ação antioxidante ao embalar óleo de girassol.

A literatura reporta alguns filmes ativos elaborados a partir de fontes renováveis que apresentam compostos ativos intrínsecos. Nesse sistema natural, substâncias bioativas estão aderidas a matriz polimérica (MUÑOZ-BONILLA; FERNÁNDEZ-GARCÍA, 2012). Maniglia et al. $(2014 ; 2015)$ produziram filmes ativos a partir de farinha de cúrcuma. A presença de curcuminóides é responsável pela atividade antioxidante dos filmes. Maniglia et al. (2017) produziram filmes de farinha e de amido de babaçu. Tanto os filmes de farinha quanto os filmes de amido de babaçu apresentaram boa atividade antioxidante devido a presença de compostos fenólicos.

Daudta et al. (2017) produziram filmes ativos de farinhas das sementes e da casca de pinha. Os filmes obtidos apresentaram boa atividade antioxidante em razão a presença de polifenóis nas cascas.

Vargas et al. (2017) produziram filmes ativos de farinha e de amido de arroz vermelho. Os grãos de arroz vermelhos são ricos em compostos fenólicos (PAIVA et al., 2016). Ambos os filmes apresentaram excelente atividade antioxidante. 


\subsubsection{Filme com atividade antimicrobiana}

A deterioração microbiana causada por microrganismos patogênicos, incluindo bactérias e fungos, reduz a vida útil dos alimentos e aumenta o risco de doenças transmitidas por alimentos e, portanto, apresenta uma grande preocupação global (BÖHME et al., 2012).

As embalagens com propriedades antimicrobianas são uma opção que reduzem, inibem ou retardam o crescimento de microrganismos que podem estar presentes nos alimentos acondicionados, visando estender a vida de prateleira do produto e obter produtos mais seguros (SOARES et al., 2009). Diante dos benefícios o desenvolvimento de embalagens ativas, com propriedades antimicrobianas, torna-se interessante (PIZZOLI, 2014).

Os filmes antimicrobianos contêm agentes antimicrobianos que interferem no crescimento ou atividade dos microrganismos, podendo ser classificados em antibacterianos ou antifúngicos (PELCZAR; REID; CHAN, 1980). Os antimicrobianos controlam a contaminação microbiana mediante três mecanismos: redução da taxa de crescimento dos microrganismos, aumento da fase lag ou inativação por contato (QUINTAVALLA; VICINI, 2002). De modo geral, os compostos antimicrobianos agem como desnaturantes de proteínas, solventes de lipídeos e agente lesante da membrana citoplasmática.

Tradicionalmente, os antimicrobianos são adicionados diretamente aos alimentos, mas sua atividade pode ser inibida por muitas substâncias do próprio alimento. Vojdani e Torres (1990), constataram que o sorbato de potássio, quando adicionado diretamente no alimento, pode ser rapidamente absorvido da superfície do alimento, perdendo seu efeito protetor nesse local. Quando o sorbato foi adicionado na matriz de um filme à base de metilcelulose e hidroxipropilmetilcelulose, o filme permitiu lenta difusão do sorbato por um tempo mais longo para a superfície do alimento, o que melhorou a sua proteção.

Neste contexto, de acordo com Cooksey (2001) os filmes antimicrobianos funcionam como um veículo para o agente antimicrobiano, ao liberar o agente antimicrobiano para a superfície do alimento, local de maior contaminação, através de evaporação no headspace (substâncias voláteis) ou ao migrar para dentro do alimento por difusão.

Os antimicrobianos podem ser adicionados aos polímeros mediante fusão ou por solubilização do composto dentro da matriz. Os agentes antimicrobianos mais utilizados são o ácido sórbico, ácido propiônico, sorbato de potássio, ácido benzóico, benzoato de sódio, ácido cítrico, prata (QUINTAVALLA; VICINI, 2002), bacteriocinas, como nisina e 
pediocina, quitosana, óleos essenciais, extratos de vegetais (SEBTI; COMA, 2002).

Os principais grupos de compostos com propriedades antimicrobianas, extraídos de plantas incluem: terpenóides e óleos essenciais (TORSSEL, 1989); alcalóides (FESSENDEN, 1982); lectinas e polipeptídios (TERRAS et al., 1993; ZHANG \& LEWIS, 1997) e substâncias fenólicas e polifenóis, que são: fenóis simples, ácidos fenólicos, quinonas (STERN et al., 1996), flavonas, flavonóis e flavonóides (FESSENDEN, 1982), tanino (SCALBERT, 1991) e cumarinas (O’KENNEDY \& THORNES, 1997), carotenoides (SHAHID-UL-ISLAM; RATHER; MOHAMMAD, 2015). Neste contexto, Carvalho et al. (2017) produziram filme antimicrobiano de acetato de celulose incorporados de uma suspensão de curcumina. Krepker et al. (2017) produziram filme antimicrobiano utilizado para embalar "hummus" a partir da combinação sinérgica de óleos essenciais, timol e carvacrol.

Emiroğlu et al. (2010) produziram filme antimicrobiano de soja incorporados de óleos essenciais de tomilho e orégano e aplicados como embalagem de hambúrgueres de carne moída. A atividade antibacteriana dos filmes foi avaliada contra Escherichia coli, Staphylococcus aureus, Pseudomonas aeruginosa e Lactobacillus plantarum. Os óleos apresentaram atividade antibacteriana semelhante para todas as bactérias testadas.

Segundo Walsh et al. (2003) os óleos essenciais de condimentos podem ter muitos componentes, como compostos fenólicos, carotenoides e outros compostos ativos, sendo estes os principais responsáveis pelas propriedades antimicrobianas dos mesmos. São compostos hidrofóbicos e o seu sítio de ação é a membrana celular da célula microbiana, onde acumulamse causando desarranjo na função e na estrutura da membrana ao penetrar a célula bacteriana, exercendo atividade inibitória no citoplasma celular, provocando lise e liberação do ATP intracelular. Enfim, agem como reguladores do metabolismo intermediário, ativando ou bloqueando reações enzimáticas, afetando diretamente uma síntese enzimática seja em nível nuclear ou ribossomal, ou mesmo alterando estruturas de membranas (SINGH \& SHUKLA, 1984).

Contudo, há algumas poucas matrizes que contêm naturalmente agentes antimicrobianos. É bastante positivo um filme ser naturalmente antimicrobiano, pois os processos de incorporação dos agentes antimicrobianos não são fáceis e geralmente quando incorporados a eficácia é reduzida já que os compostos ativos são sensíveis a luz, temperatura (KREPKER et al., 2017).

Yuan, chen e Li (2016), relatam a natural atividade antimicrobiana de filmes de 
quitosana, assim como a melhora da atividade antimicrobiana destes filmes ao incorporar óleos essenciais. A quitosana tem sido muito utilizada na composição de filmes antimicrobianos, porque, além de ter boas propriedades formadoras de filmes, possui ação bactericida e fungicida. Esta ação é devida a sua capacidade de ligar-se às moléculas de água, inativar as enzimas microbianas e absorver os nutrientes usados pelos microrganismos (OUATTARA et al., 2000). Os revestimentos à base de quitosana aplicados em frutas induzem à produção da enzima quitinase, que é um agente antifúngico natural (DEBEAUFORT; QUEZADAGALLO; VOILLEY, 1998). Em fungos, a quitosana pode também produzir alterações nas funções da membrana, por interação com a superfície eletronegativa deles, levando a mudanças na permeabilidade, distúrbios metabólicos e morte celular (FANG; LI; SHIN, 1994). Segundo Muzzarelli et al. (1990) a atividade antimicrobiana da quitosana sobre bactérias é devida à natureza policatiônica da molécula de quitosana, que permite a interação e formação de complexos polieletrólitos com os polímeros ácidos produzidos na superfície da bactéria (lipopolissacarídeos, ácido teicóico e teicurônico). Filmes e revestimentos à base de quitosana testados sobre Listeria monocytogenes inibiram o crescimento desse microrganismo (COMA et al., 2002). El Ghaouth et al. (1992) mostraram que revestimentos à base de 1 e $2 \%$ de quitosana reduziram no tomate a incidência de deterioração, principalmente a causada por Botrytis cinérea. Para filmes de quitosana, pesquisadores correlacionam a atividade antimicrobiana à formação de complexos polieletrolíticos, uma vez que seus grupos amínicos protonados provavelmente se ligam seletivamente à superfície celular carregada negativamente dos micro-organismos, alterando a atividade celular e a permeabilidade da membrana, resultando na perda de componentes intracelulares e, consequente, inibição microbiana (AVADI et al., 2004).

As farinhas de urucum utilizadas neste trabalho para produção dos filmes são ricas em compostos ativos, tais como compostos fenólicos e carotenóides. De acordo com Shahid-ulislam; Rather; Mohammad, (2015) o extrato etanólico de sementes de urucum apresentou ação contra Bacillus subtilis, Staphylococcus aureus, Streptococcus pyogenes, Salmonella typhi, Pseudomonas aeruginosa, Escherichia coli e Candida albicans. Os principais compostos responsáveis pela atividade antimicrobiana são os carotenoides (9'-cis-norbixina e all-transnorbixina) (GALINDO-CUSPINERA; WESTHOFF; RANKIN, 2003). Portanto, espera-se que os filmes de farinha de urucum produzidos neste presente trabalho apresentem atividade antimicrobiana. 
Alguns fatores podem afetar a efetividade da embalagem antimicrobiana, como as características do antimicrobiano (solubilidade e tamanho da molécula) e do alimento, condições de estocagem e distribuição (tempo e temperatura), método de preparo do filme (extrusão ou casting) e interação entre antimicrobiano e polímero (SOARES et al., 2009).

\subsection{Referências Bibliográficas}

ABAYOMI, M. et al. In vitro antioxidant activity of Bixa orellana (Annatto) seed extract. J Appl Pharm Sci, v. 4, p. 101-6, 2014.

AGAMA-ACEVEDO, E. et al. Starch isolation and partial characterization of commercial cooking and dessert banana cultivars growing in Mexico. Starch - Stärke, v. 66, n. 3-4, p. 337-344, mar. 2014.

AlBUQUerque, C. L. C.; MEIRELES, M. A. A. Defatting of annatto seeds using supercritical carbon dioxide as a pretreatment for the production of bixin: Experimental, modeling and economic evaluation of the process. The Journal of Supercritical Fluids, v. 66, p. 86-95, jun. 2012.

ALMEIDA, D. M. ET AL. Propriedades físicas, químicas e de barreira em filme formados por blenda de celulose bacteriana e fécula de batata. Polímeros, v. 23, n. 4, p. 538-546, 2013.

ALVES, M. M. T. R. Embalagens Biodegradáveis. Instituto ed. Lisboa-Portugal: INSTITUTO PIAGET, 2003.

ANDRADE-MAHECHA, M. M.; TAPIA-BLÁCIDO, D. R.; MENEGALLI, F. C. Development and optimization of biodegradable films based on achira flour. Carbohydrate Polymers, v. 88, n. 2, p. 449-458, 2012.

ARVANITOYANNIS, I. S.; KASSAVETI, A. Starch-cellulose blends. Biodegradable polymer blends and composites from renewable resources, p. 17-53, 2009.

AVADI, M. R. et al. Diethylmethyl chitosan as an antimicrobial agent: Synthesis, characterization and antibacterial effects. European Polymer Journal, v. 40, n. 7, p. 13551361, jul. 2004.

BARROSO, G. M. Sistemática de angiospermas do Brasil. São Paulo: Universidade de São Paulo, 1978.

BATISTA, J. A. Desenvolvimento, Caracterização e Aplicações de Biofilmes a Base de Pectina, Gelatina e Ácidos Graxos em Bananas e Sementes de Brócolos. Campinas: Universidade Estadual de Campinas, 2004.

BELHADI, B. et al. Three small-scale laboratory steeping and wet-milling procedures for isolation of starch from sorghum grains cultivated in Sahara of Algeria. Food and Bioproducts Processing, v. 91, n. 3, p. 225-232, 2013.

BODAGHI, H. et al. Evaluation of the photocatalytic antimicrobial effects of a TiO2 nanocomposite food packaging film by in vitro and in vivo tests. LWT - Food Science and Technology, v. 50, n. 2, p. 702-706, mar. 2013. 
BODMEIER, R; PAERATAKUL, O. Plasticizer uptake by aqueous colloidal polymer

dispersions used for the coating of solid dosage forms. International Journal of Pharmaceutics, p. 17-26, 1997.

BÖHME, K. et al. Species Identification of Food Spoilage and Pathogenic Bacteria by MALDITOF Mass Fingerprinting. In: Agricultural and Biological Sciences. [s.l: s.n.].

BRAGA, F. G. et al. Antileishmanial and antifungal activity of plants used in traditional medicine in Brazil. Journal of Ethnopharmacology, v. 111, n. 2, p. 396-402, maio 2007.

BRASIL. Resolução ${ }^{0} 12$, de 1978. Normas Técnicas Especiais. In: Comissão Nacional de Normas e Padrões para Alimentos. Brasília, DF: Diário Oficial da União, 1978.

BRAZ, N. D. M. et al. Semente residual do urucum na alimentação de poedeiras comerciais: desempenho e características dos ovos. Acta Scientiarum. Animal Sciences, v. 29, n. 2, p. 129-133, 14 nov. 2007.

BRITO, J. G. DE et al. Revista Brasileira de Engenharia Agrícola e Ambiental Armazenamento de grãos residuais de urucum sob atmosfera controlada Storage of waste grains of annatto under controlled atmosphere. p. 1185-1191, 2015.

BULÉON, A. et al. Starch granules: Structure and biosynthesis. International Journal of Biological Macromolecules, v. 23, n. 2, p. 85-112, 1998.

CAMPBELL, R. E.; BOOGERS, I. A. L. A.; DRAKE, M. A. Short communication:

Development of a novel method for the extraction of norbixin from whey and its subsequent quantification via high performance liquid chromatography. Journal of Dairy Science, v. 97, n. 3, p. 1313-1318, mar. 2014.

CARR, L. G. ET AL. Influência da adição de caulim e CaCO3 nas propriedades mecânicas das espumas de amido. Congresso Brasileiro de Engenharia e Ciências dos materiais, CBECiMat, Foz do Iguaçu. Anais...2006

CARVALHO, D. DE M. et al. Filme ativo de acetato de celulose incorporado com nanosuspensão de curcumina. Polímeros, v. 27, 2017.

CASTRO, C. B. et al. A cultura do urucum. Brasília.: Empresa Brasileira de Pesquisa Agropecuária, Centro de Pesquisa Agroflorestal da Amazônia Oriental., 1994.

COMA, V. et al. Edible Antimicrobial Films Based on Chitosan Matrix. Journal of Food Science, v. 67, n. 3, p. 1162-8, 2002.

COMA, V. Polysaccharide-based Biomaterials with Antimicrobial and Antioxidant Properties. Polímeros Ciência e Tecnologia, v. 20, n. 2, 2013.

CONSTANT, P. B. L.; STRINGHETA, P. C.; SANDI, D. Corantes Alimentícios. . 2002, p. 20(2): 203-220.

COOKSEY, K. Antimicrobial food packaging materials. Additives for Polymers, v. 2001, n. 8, p. 6-10, ago. 2001.

CORREA, M. P. Dicionário de plantas úteis do Brasil e das exóticas cultivadas. Rio de Janeiro: Nacional, Imprensa, 1978.

CORREIA, P. R.; BEIRÃO-DA-COSTA, M. L. Starch isolation from chestnut and acorn flours through alkaline and enzymatic methods. Food and Bioproducts Processing, v. 90, n. 2, p. 
$309-316,2012$.

CORREIA, P. R.; NUNES, M. C.; BEIRÃO-DA-COSTA, M. L. The effect of starch isolation metthod on physical and functional properties of Portuguese nut starches. II. Q. rotundifolia Lam. and Q. suber Lam. acorns starches. Food Hydrocolloids, v. 30, n. 1, p. 448-455, 2013.

CUQ, B.; GONTARD, N.; GUILBERT, S. Thermoplastic properties of fish myofibrillar proteins: application to biopackaging fabrication. Polymer, v. 38, n. 16, p. 4071-4078, ago. 1997.

DANTAS, E. A. et al. Caracterização e avaliação das propriedades antioxidantes de filmes biodegradáveis incorporados com polpas de frutas tropicais. Ciência Rural, v. 45, n. 1, p. 142 $148,2015$.

DAUDT, R. M. et al. Comparative study on properties of edible films based on pinho (Araucaria angustifolia ) starch and flour. Food Hydrocolloids, v. 60, p. 279-287, out. 2016.

DAUDTA, R. M. et al. Development of edible films based on Brazilian pine seed (Araucaria angustifolia) flour reinforced with husk powder. Food Hydrocolloids, v. 71, p. 60-67, 2017.

DEBEAUFORT, F.; QUEZADA-GALLO, J.-A.; VOILLEY, A. Edible Films and Coatings: Tomorrow's Packagings: A Review. Critical Reviews in Food Science and Nutrition, v. 38, n. 4, p. 299-313, maio 1998.

DIAS, A. B. et al. Biodegradable films based on rice starch and rice flour. Journal of Cereal Science, v. 51, n. 2, p. 213-219, 2010.

DOI \& FUKUDA. Biodegradable plastics and polymers. Amsterdam: Elsevier Ltd, 1994. EL

GHAOUTH, A. et al. Chitosan Coating to Extend the Storage Life of Tomatoes.

HortScience, v. 27, n. 9, p. 1016, 1992.

EMIROĞLU, Z. K. et al. Antimicrobial activity of soy edible films incorporated with thyme and oregano essential oils on fresh ground beef patties. Meat Science, v. 86, p. 283-28, 2010.

ESTRADA-LEÓN, R. J. et al. The effect of isolation method on properties of parota (Enterolobium cyclocarpum) starch. Food Hydrocolloids, v. 57, p. 1-9, 2016.

FANG, S. W.; LI, C. F.; SHIN, D. Y. C. Antifungal Activity of Chitosan and Its Preservative Effect on Low-Sugar Candied Kumquat. Journal of Food Protection, v. 57, n. 2, p. 136-140, fev. 1994

FLEISCHER, T. C. et al. Antimicrobial activity of the leaves and seeds of Bixa Orellana Fitoterapia, v. 74, n. 1-2, p. 136-8, fev. 2003.

FRANCO, C. F. O. et al. Urucuzeiro: Agronegócio de Corantes Naturais. Emepa ed. João Pessoa: SAIA, 2002.

FRANCO, C. F. O. Corantes naturais de urucum (Bixa orellana L.) no tratamento da hiperlipidemia em animais e câncer em animais. [s.l.] Universidade Federal de Viçosa, 2008.

FRENCH, D. Organization of starch granules. In: WHISTLER, R. L.; BEMILLER, J. N.; PASCHAL, E. F. (Eds.). . Starch: Chemistry and Technology. London: Academic Press, 1984. p. $183-247$.

GALINDO-CUSPINERA, V.; LUBRAN, M. B.; RANKIN, S. A. Comparison of volatile compounds in water- and oil-soluble annatto (Bixa orellana L.) extracts. Journal of 
agricultural and food chemistry, v. 50, n. 7, p. 2010-5, 27 mar. 2002.

GALINDO-CUSPINERA, V.; WESTHOFF, D. C.; RANKIN, S. A. Antimicrobial properties of commercial annatto extracts against selected pathogenic, lactic acid, and spoilafe microorganisms. Journal of Food Protection, v. 66, n. 6, p. 1074-1078, 2003.

GARCIA, C. E. R. et al. Carotenoides bixina e norbixina extraídos do urucum (Bixa orellana L.) como antioxidantes em produtos cárneos. Ciência Rural, v. 42, n. 8, p. 1510-1517, ago. 2012.

GIULIANO, G.; ROSATI, C.; BRAMLEY, P. M. To dye or not to dye: biochemistry of annatto unveiled. Trends in biotechnology, v. 21, n. 12, p. 513-6, dez. 2003.

GONTARD, N.; GUILBERT, S. Bio-packaging: technology and properties of edible and/or biodegradable material of agricultural origin. In: Food Packaging and Preservation. Boston, MA: Springer US, 1994. p. 159-181.

GONTARD, N.; GUILBERT, S.; CUQ, J.-L. Edible Wheat Gluten Films: Influence of the Main Process Variables on Film Properties using Response Surface Methodology. Journal of Food Science, v. 57, n. 1, p. 190-195, jan. 1992.

GONTARD, N.; GUILBERT, S.; CUQ, J.-L. Water and Glycerol as Plasticizers Affect Mechanical and Water Vapor Barrier Properties of an Edible Wheat Gluten Film. Journal of Food Science, v. 58, n. 1, p. 206-211, jan. 1993.

GRINBERG, V. Y.; TOLSTOGUZOV, V. B. Thermodynamic incompatibility of proteins and polysaccharides in solutions. Food Hydrocolloids, v. 11, n. 2, p. 145-158, 1997.

GUILBERT, S. Technology and application of edible protective films. Food packaging and preservation, p. 371-394, 1986.

HALLIWELL, B.; GUTTERIDGE, J. M. . Free radicals in biology and medicine. n. 5, p. 899, 1999.

HENRIQUE, C. M.; CEREDA, M. P.; SARMENTO, S. B. S. Características físicas de filmes biodegradáveis produzidos a partir de amidos modificados de mandioca. Ciência e Tecnologia de Alimentos, p. 231-240, 2008.

HENRY, B. S. Natural food colours. In: HENDRY, G. A. F.; HOUGHTON, J. D. (Eds.). . Natural Food Colorants. 2. ed. Boston, MA: Springer US, 1996. p. 40-79.

HIZUKURI, S. Polymodal distribution of the chain lengths of amylopectins, and its significance. Carbohydrate Research, v. 147, n. 2, p. 342-347, 4 mar. 1986.

HOOVER, R. Composition, molecular structure, and physicochemical properties of tuber and root starches: a review. Carbohydrate Polymers, v. 45, n. 3, p. 253-267, jul. 2001.

HOTCHKISS, J. H. Safety considerations in active packaging. In: Active Food Packaging. Boston, MA: Springer US, 1995. p. 238-255.

IBGE. Produção agrícola municipal : culturas temporárias e permanentes. IBGE ed. Rio de Janeiro: Rio de Janeiro, 2014. v. 41

JENKINS, D.; RICHARD, M. G.; DAIGGER, G. T. Manual on the causes and control of activated sludge bulking and foaming. Manual on the causes and control of activated sludge bulking and foaming, 1993. 
KANG, E. J. et al. Invited review: Annatto usage and bleaching in dairy foods. Journal of

dairy science, v. 93, n. 9, p. 3891-901, set. 2010.

KESTER, J. J. AND FENNEMA, O. R. Edible films and coatings: A review. Food Technology, p. 47-59, 1986.

KIOKIAS, S. Antioxidant properties of annatto carotenoids. Food Chemistry, v. 83, n. 4, p. 523-529, dez. 2003.

KRAMER, M. E. Structure and Function of Starch-Based Edible Films and Coatings. In: Edible Films and Coatings for Food Applications. New York, NY: Springer New York, 2009. p. 113-134.

KREPKER, M. et al. Active food packaging films with synergistic antimicrobial activity. Food Control, v. 76, p. 117-126, 2017.

KRINSKY, N. I. Antioxidant functions of carotenoids. Free radical biology \& medicine, v. 7, n. 6, p. 617-35, 1989.

KROCHTA, J. M.; DE MULDER-JOHNSTON, C. L. C. Biodegradable Polymers from Agricultural Products. In: [s.l: s.n.]. p. 120-140.

LI, J.-H. et al. Preparation and characterization of active gelatin-based films incorporated with natural antioxidants. Food Hydrocolloids, v. 37, p. 166e173, 2014.

LIMA, L. R. P. et al. Bixina, Norbixina e Quercetina e seus efeitos no metabolismo lipídico de coelhos. Brazilian Journal of Veterinary Research and Animal Science, v. 38, n. 4, p. 196 $200,2001$.

LINEBACK, D. R. The starch granule: Organization and properties. Bakers Digest, v. 58, n. 2, p. 16-21, 1984.

LÓPEZ-MATA, M. A. et al. Physicochemical and Antioxidant Properties of Chitosan Films Incorporated with Cinnamon Oil. International Journal of Polymer Science, v. 2015, p. 8, 2015.

LORENZI, H. Árvores brasileiras: manual de identificação e cultivo de plantas arbóreas nativas do Brasil. Nova Odessa: Plantarum, 1998.

MAJOLO, C.; CARVAlHO, H. H.; WIEST, J. M. Atividade antibacteriana "in vitro" de diferentes acessos de urucum (BIXA ORELLANA 1.) e sua relação com o teor de bixina presente nas sementes. Boletim do Centro de Pesquisa de Processamento de Alimentos, V 31, n. 1, 12 jul. 2013.

MAJZOOBIA, M. et al. Physical properties of biodegradable films from heat-moisture-treated rice flour and rice starch. Starch/Stärke, v. 67, p. 1053-1060, 2015.

MALI, S. et al. Microstructural characterization of yam starch films. Carbohydrate Polymers, v. 50, n. 4, p. 379-386, dez. 2002.

MANIGLIA, B. C. et al. Development of bioactive edible film from turmeric dye solvent extraction residue. LWT - Food Science and Technology, v. 56, n. 2, p. 269-277, maio 2014.

MANIGLIA, B. C. et al. Turmeric dye extraction residue for use in bioactive film production: Optimization of turmeric film plasticized with glycerol. LWT - Food Science and Technology, v. 64 , n. 2, p. 1187-1195, dez. 2015. 
MANIGLIA, B. C. et al. Bioactive films based on babassu mesocarp flour and starch. Food

Hydrocolloids, v. 70, p. 383-391, 2017.

MANIGLIA, B. C.; TAPIA-BLÁCIDO, D. R. Isolation and characterization of starch from babassu mesocarp. Food Hydrocolloids, v. 55, p. 47-55, abr. 2016.

MANTOVANI, N. C. et al. Avaliação de genótipos de urucum (Bixa orellana L.) por meio da caracterização morfológica de frutos, produtividade de sementes e teor de bixina. Ciência Florestal, v. 23, n. 2, jun. 2013.

MERCADANTE, A. ; STECK, A.; PFANDER, H. Three minor carotenoids from annatto (Bixa orellana) seeds. Phytochemistry, v. 52, n. 1, p. 135-139, set. 1999.

MONTAÑO-LEYVA, B. ET AL. Biocomposites from wheat proteins and fibers: Structure/mechanical properties relationships. Industrial Crops and Products, v. 43, p. 545$555,2003$.

MOORTHY, S. N.; LARSSON, H.; ELIASSON, A.-C. Rheological Characteristics of Different Tropical Root Starches. Starch - Stärke, v. 60, n. 5, p. 233-247, maio 2008.

MORAES, A. S. et al. Balanço Nitrogenado de caprinos alimentados com dietas contendo subproduto de urucum (Bixa orellana L.). V Congresso Nordestino de Produção Animal. Anais. Anais...Aracaju: 2008

MOREIRA, P. A. et al. The Domestication of Annatto (Bixa orellana) from Bixa urucurana in Amazonia. Economic Botany, v. 69, n. 2, p. 127-135, 5 jun. 2015.

MUÑOZ-BONILLA, A.; FERNÁNDEZ-GARCÍA, M. Polymeric materials with antimicrobial activity. Progress in Polymer Science, v. 37, n. 2, p. 281-339, fev. 2012.

MUZZARELLI, R. et al. Antimicrobial properties of N-carboxybutyl chitosan. Antimicrobial agents and chemotherapy, v. 34, n. 10, p. 2019-23, out. 1990.

NERÍN, C.; TOVAR, L.; SALAFRANCA, J. Behaviour of a new antioxidant active film versus oxidizable model compounds. Journal of Food Engineering, v. 84, n. 2, p. 313-320, 2008.

OCAMPO, R. A. S. Aspectos agronómicos sobre el cultivo del achiote (Bixa orellana L.). In: Aspectos sobre el achiote y perspectivas para Costa Rica. Cartago, Costa Rica: CATIE, 1983. p. 43-57.

OJEDA, T. Polymers and the Environment. Polymer Science, 2013.

OLIVEIRA, J. S. Caracterização, extração e purificação por cromatografia de compostos de urucum (Bixa orellana L.). [s.1.] Universidade Federal de Santa Catarina, 2005.

OTHMAN, Z.; AL-ASSAF, S.; HASSAN, O. Molecular characterisation of sago starch using gel permeation chromatography multi-angle laser light scattering. Sains Malaysiana, v. 39, n. 6, p. 969-973, 2010.

OUATTARA, B. et al. Inhibition of surface spoilage bacteria in processed meats by application of antimicrobial films prepared with chitosan. International Journal of Food Microbiology, v. 62 , n. 1-2, p. 139-148, dez. 2000.

PAGNO, C. H. et al. Synthesis of biodegradable films with antioxidant properties based on cassava starch containing bixin nanocapsules. Journal Food Science Technology, v. 53, n. 8, p. $3197-3205,2016$. 
PAIVA, F. F. et al. Polishing and parboiling effect on the nutritional and technological

properties of pigmented rice. Food Chemistry, v. 191, p. 105-112, 2016.

PALACIOS-FONSECA, A. J. et al. Effect of the alkaline and acid treatments on the physicochemical properties of corn starch. CyTA - Journal of Food, v. 11, n. sup1, p. 67-74, maio 2013.

PELCZAR, M.; REID, R.; CHAN, E. C. S. Microbiologia. São Paulo: McGraw-Hill, 1980.

PELISSARI, F. M. et al. Optimization of process conditions for the production of films based on the flour from plantain bananas (Musa paradisiaca). LWT - Food Science and Technology, v. 52, n. 1, p. 1-11, jun. 2013.

PERAZZO, K. K. N. C. L., CONCEIÇÃO, A. C. D. V. et al. Properties and Antioxidant Action of Actives Cassava Starch Films Incorporated with Green Tea and Palm Oil Extracts. PLOS ONE, v. 9, n. 9, 2014.

PIERPAOLI, E. et al. Effect of annatto-tocotrienols supplementation on the development of mammary tumors in HER-2/neu transgenic mice. Carcinogenesis, v. 34, n. 6, p. 1352-1360, 1 jun. 2013.

PINO, J. A.; CORREA, M. T. Chemical Composition of the Essential Oil from Annatto (Bixa orellana L.) Seeds. Journal of Essential Oil Research, v. 15, n. 2, p. 66-67, mar. 2003.

PIZZOLI, A. P. O. Produção e caracterização de laminados biodegradáveis e antimicrobianos para embalagens de alimentos. Campo Mourão: Universidade Tecnológica Federal do Paraná, 2014.

PRABHAKARA RAO, P. G. et al. Effect of processing conditions on the stability of annatto (Bixa orellana L.) dye incorporated into some foods. LWT - Food Science and Technology, v. 38, n. 7, p. 779-784, nov. 2005.

QUINTAVALLA, S.; VICINI, L. Antimicrobial food packaging in meat industry. Meat Science, v. 62, n. 3, p. 373-380, nov. 2002.

RIOS, A. DE O.; MERCADANTE, A. Z.; BORSARELLI, C. D. Triplet state energy of the carotenoid bixin determined by photoacoustic calorimetry. Dyes and Pigments, v. 74, n. 3, p. 561-565, jan. 2007.

ROCHA GARCIA, C. E. ET AL. Antioxidantes utilizados na indústria cárnea: quais são os aditivos inibidores da rancidez nos produtos cárneos. Revista Nacional da Carne, v. 26, n 299, p. 36-51, 2002.

ROJAS, J. J. et al. Screening for antimicrobial activity of ten medicinal plants used in Colombian folkloric medicine: A possible alternative in the treatment of non-nosocomial infections. BMC Complementary and Alternative Medicine, v. 6, n. 1, p. 2, 17 dez. 2006.

ROONEY, M. L. Overview of active food packaging. In: Active Food Packaging. Boston, MA: Springer US, 1995. p. 1-37.
SALAS-VALERO, L. M.; TAPIA-BLÁCIDO, D. R.; MENEGALLI, F. C. BIOFILMS BASED
ON CANIHUA FLOUR (Chenopodium Pallidicaule): DESIGN AND CHARACTERIZATION. Química Nova, 2014.

SAMPAIO, G. R. et al. Effect of natural antioxidant combinations on lipid oxidation in cooked chicken meat during refrigerated storage. Food Chemistry, v. 135, n. 3, p. 1383-1390, 2012. 
SANTANA, M. C. C. B. DE et al. Incorporação de urucum como aditivo antioxidante em embalagens biodegradáveis a base de quitosana. Ciência Rural, 2012.

SANTOS, L. F. et al. Spectroscopic and photothermal characterization of annatto: Applications in functional foods. Dyes and Pigments, v. 110, p. 72-79, nov. 2014.

SANTOS, L. S. ET AL. Efeito dos métodos de extração na composição, rendimento e propriedades da pasta do amido obtido da semente de jaca. Revista Brasileira de Produtos Agroindustriais, v. 15, n. 3, p. 255-261, 2013.

SATYANARAYANA, A. et al. Application of annatto dye formulations in different fruit and vegetable products. Journal of Foodservice, v. 17, n. 1, p. 1-5, fev. 2006.

SCOTTER, M. The chemistry and analysis of annatto food colouring: a review. Food Additives \& Contaminants: Part A, v. 26, n. 8, p. 1123-1145, ago. 2009.

SCOTTER, M. J. et al. Analysis of Annatto (Bixa orellana) Food Coloring Formulations. 1. Determination of Coloring Components and Colored Thermal Degradation Products by High-

Performance Liquid Chromatography with Photodiode Array Detection. J. Agric. Food Chem., v. 46, n. 3, p. 1031-1038, 1998.

SEBTI, I.; COMA, V. Active edible polysaccharide coating and interactions between solution coating compounds. Carbohydrate Polymers, v. 49, n. 2, p. 139-144, ago. 2002.

SHAHID-UL-ISLAM; RATHER, L. J.; MOHAMMAD, F. Phytochemistry, biological activities and potential of annatto in natural colorant production for industrial applications - A review. Journal of Advanced Research, v. 7, n. 3, p. 499-514, 2015.

SILVA, E. K. et al. Ultrasound-assisted formation of annatto seed oil emulsions stabilized by biopolymers. Food Hydrocolloids, v. 47, p. 1-13, maio 2015.

SILVA, P. I. Métodos de extração e caracterização de bixina e norbixina em sementes de urucum. Viçosa: Universidade Federal de Viçosa, 2007.

SILVA, J. H. V. DA et al. Efeitos da inclusão do resíduo da semente de urucum (Bixa orellana L.) na dieta para frangos de corte: desempenho e características de carcaça. Revista Brasileira de Zootecnia, v. 34, n. 5, p. 1606-1613, out. 2005.

SOARES, N. DE F. F. et al. Novos desenvolvimentos e aplicações em embalagens de alimentos. Ceres, 2009.

SUN, Q. et al. Effects of different isolation methods on the physicochemical properties of pea starch and textural properties of vermicelli. Journal of Food Science and Technology, v. 52, n. 1, p. 327-334, 3 jan. 2015.

SYLVESTER, P. W.; SHAH, S. J. Mechanisms mediating the antiproliferative and apoptotic effects of vitamin $\mathrm{E}$ in mammary cancer cells. Frontiers in bioscience : a journal and virtual library, v. 10, p. 699-709, 1 jan. 2005.

TAHAM, T.; CABRAL, F. A.; BARROZO, M. A. S. Extraction of bixin from annatto seeds using combined technologies. The Journal of Supercritical Fluids, v. 100, p. 175-183, maio 2015.

TAPIA-BLÁCIDO, D. et al. Contribution of the Starch, Protein, and Lipid Fractions to the 
Physical, Thermal, and Structural Properties of Amaranth (Amaranthus caudatus) Flour Films.

Journal of Food Science, v. 72, n. 5, p. E293-E300, jun. 2007.

TAPIA-BLÁCIDO, D.; SOBRAL, P. J.; MENEGALLI, F. C. Development and characterization of biofilms based on Amaranth flour (Amaranthus caudatus). Journal of Food Engineering, v. 67, n. 1-2, p. 215-223, mar. 2005.

TESTER, R. F.; KARKALAS, J.; QI, X. Starch-composition, fine structure and architecture. Journal of Cereal Science, v. 39, n. 2, p. 151-165, mar. 2004.

THARANATHAN, R. . Biodegradable films and composite coatings: past, present and future. Trends in Food Science \& Technology, v. 14, n. 3, p. 71-78, mar. 2003.

TIRIMANNA, A. S. L. Study of the carotenoid pigments of Bixa orellana L. Seeds by thin layer chromatography. Mikrochimica Acta, v. 76, n. 1-2, p. 11-16, jan. 1981.

TOCCHINI, L.; MERCADANTE, A. Z. EXTRAÇÃO E DETERMINAÇÃO, POR CLAE, DE BIXINA E NORBIXINA EM COLORÍFICOS. Ciência e Tecnologia de Alimentos, v. 21, n. 3, dez. 2001.

TYAGI, A. K. et al. Essential oil vapour and negative air ions: A novel tool for food preservation. Trends in Food Science \& Technology, v. 26, n. 2, p. 99-113, ago. 2012.

UTIYAMA, C. E.; MIYADA, V. S.; FIGUEIREDO, A. N. Digestibilidade de nutrientes do resíduo de semente processadas de urucum (Bixa orellana) para suínos. Reunião anual da sociedade brasileira de zootecnia. Anais: Sociedade Brasileira de Zootecnia. Anais...Recife: 2002

VALÉRIO, M. A. et al. Annatto seed residue (Bixa orellana L.): nutritional quality. Food Science and Technology (Campinas), v. 35, n. 2, p. 326-330, jun. 2015.

VARGAS, C. G. et al. Comparative Study on the Properties of Films Based on Red Rice (Oryza glaberrima) Flour and Starch. Food Hydrocolloids, v. 65, p. 96-106, 2017.

VERMEIREN, L. et al. Developments in the active packaging of foods. Trends in Food Science \& Technology, v. 10, n. 3, p. 77-86, mar. 1999.

VERMEIREN, L.; DEVLIEGHERE, F.; DEBEVERE, J. Effectiveness of some recent antimicrobial packaging concepts. Food additives and contaminants, v. 19 Suppl, p. 163-71, 2002.

VICENTINO, S. L. et al. Filmes de amidos de mandioca modificados para recobrimento e conservação de uvas. Química Nova, v. 34, n. 8, p. 1309-1314, 2011.

VOJDANI, F.; TORRES, J. A. Potassium Sorbate Permeability of Methylcellulose and Hydroxypropyl Methylcellulose Coatings: Effect of Fatty Acids. Journal of Food Science, v. 55, n. 3, p. 841-846, maio 1990.

WALSH, S. E. et al. Activity and mechanisms of action of selected biocidal agents on Grampositive and -negative bacteria. Journal of applied microbiology, v. 94, n. 2, p. 240-7, 2003.

YUAN, G.; CHEN, X.; LI, D. Chitosan films and coatings containing essential oils: The antioxidant and antimicrobial activity, and application in food systems. Food Research International, 2016. 
Capítulo 2. EFEITO DO MÉTODO DE ISOLAMENTO DE AMIDO A PARTIR DO RESÍDUO DA EXTRAÇÃO DE CORANTE DE URUCUM 


\section{Apresentação}

O efeito do método de isolamento de amido a partir do resíduo de urucum sobre as propriedades físico-químicas, térmicas, morfologia e propriedades antioxidantes do material obtido foram estudadas neste capítulo. Os métodos de isolamento foram: moagem em água (WS), moagem em pH ácido (AS) e moagem em pH alcalino (KS). Os materiais obtidos no isolamento foram caracterizados em composição química, distribuição de partícula, microscopia eletrônica de varredura, cor, teor de compostos fenólicos, carotenoides, teor de bixina, atividade antioxidante, espectroscopia de infravermelho, difração de raios-X, calorimetria diferencial de varredura. Os resultados demonstraram que os materiais isolados com os três métodos testados não podem ser considerados como amido, pois a pureza em amido dos materiais foi ao redor de $65 \%$. Portanto, estes materiais foram considerados farinhas com alto teor de amido, sendo obtidas três tipos de farinha WS (65\% de amido), farinha AS (66\% de amido) e farinha KS ( $69 \%$ de amido) segundo o método de isolamento com diferenças na sua composição centesimal, estrutura e teor de compostos bioativos.

\subsection{Materiais e métodos}

\subsubsection{Materiais}

O resíduo da extração de corante de urucum foi fornecido pela empresa de corantes Firace (São Paulo, Brasil). O resíduo foi transportado e armazenado em embalagem escura (polietileno de baixa densidade) a $10^{\circ} \mathrm{C}$. De acordo com a Firace, a extração do corante de urucum foi realizada utilizando óleo de soja, com rendimento na extração de $90 \%$.

Os reagentes: hidróxido de sódio e ácido ascórbico P.A foram adquiridos pela DinâmicaQuímica Contemporânea, (São Paulo, Brasil). O radical ABTS (2,2'-azinobis (3etilbenzoatiazolina-6-ácido sulfônico)), o antioxidante sintético BHT (2,6-Di-tert-butyl-4methylphenol), o antioxidante sintético Trolox ((+)-6-Hydroxy-2,5,7,8-tetramethylchromane2-carboxylic acid) e o padrão bixina (95\%) foram adquiridos da Sigma-Aldrich, (São Paulo, Brasil). 


\subsubsection{Isolamento de farinhas a partir do resíduo da extração do corante de urucum}

O isolamento de farinhas a partir do resíduo da extração de corante de urucum foi realizado, empregando-se três métodos: moagem em água (WS), moagem em pH ácido (AS) e moagem em $\mathrm{pH}$ alcalino (KS), conforme metodologia descrita por Maniglia e Tapia-Blácido (2016), como mostrada na Fig. 2.1. Então, o resíduo de urucum foi imerso em água deionizada (método em água/neutro - $\mathrm{pH} 7$ ), ou em solução de $0,25 \%$ de hidróxido de sódio (método alcalino - pH 10), ou em solução de 1\% de ácido ascórbico (método ácido - pH 3), seguindo a proporção 1:2 (resíduo de urucum: solução) por 18 horas a $10{ }^{\circ} \mathrm{C}$. Em seguida, a mistura passou por moagem em liquidificador Oster (modelo 6844-017, $450 \mathrm{~W}$ ) por 2 minutos. O material moído foi peneirado utilizando peneiras de 80, 200 e 270 mesh (Bertel, Brasil). O material retido foi reprocessado no liquidificador (4 vezes) e o material passante foi centrifugado em centrífuga Quimis (Q222RM, Brasil) à $1500 \mathrm{rpm}$ por $10 \mathrm{~min}, 10^{\circ} \mathrm{C}$. Para a extração da farinha em pH ácido ou alcalino, o material passante foi lavado e centrifugado, nas mesmas condições, até pH 7. Tanto o material retido (farelo) quanto o material passante (farinha: fração rica em amido) foram secos em estufa com circulação forçada à $40{ }^{\circ} \mathrm{C}$ (Quimis, Q314M292, Brasil) por $12 \mathrm{~h}$ e em seguida, foram moídos, peneirados (80 mesh) e armazenados em frascos âmbar, sobrefrigeração $\left(10^{\circ} \mathrm{C}\right)$. 
Figura 2.1 - Fluxograma do processo de isolamento de farinhas a partir do resíduo da extração de corante de urucum por moagem em água (WS), moagem em pH ácido (AS) e moagem em $\mathrm{pH}$ alcalino (KS)

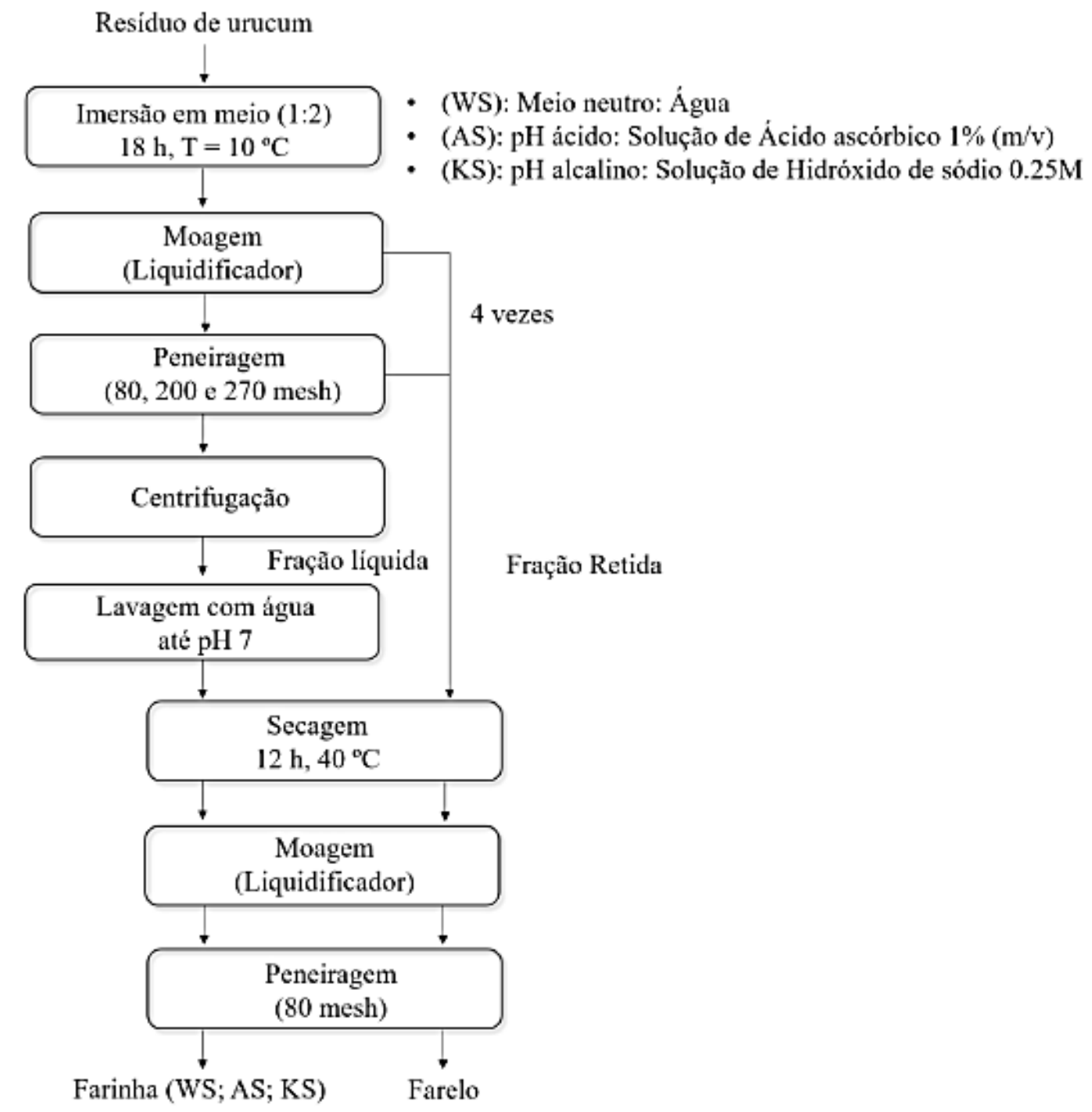

\subsubsection{Composição química}

O resíduo da extração de corante de urucum e as farinhas obtidas nos métodos de isolamento por moagem em água (WS), moagem em pH ácido (AS) e moagem em pH alcalino (KS) foram caracterizados em função a sua composição centesimal. As análises foram feitas em triplicata, com exceção da análise de fibra alimentar total que foi feita em quadruplicata. 


\subsubsection{Umidade}

A determinação de umidade foi realizada segundo pelo método gravimétrico $\mathrm{n}^{\circ} 920.151$ da AOAC (AOAC-920.151, 1997). 2,0 g de amostra foram pesadas em cadinho de porcelana previamente tarado. A amostra foi colocada em estufa com circulação forçada de ar (QUIMIS, Q314M292, Brasil) à $105^{\circ} \mathrm{C}$ por 24 horas. $\mathrm{O}$ teor de umidade foi calculado pela equação 1 .

$$
\% \text { Umidade }=\frac{M_{\text {água }}}{M_{A}} \times 100
$$

Sendo: $M_{\text {água }}$ : massa de água (a diferença entre a massa de cadinho com a amostra úmida e a amostra seca) e $M_{A}$ : massa da amostra seca.

\subsubsection{Cinzas}

A determinação de cinzas foi realizada segundo o método gravimétrico $n^{\circ} 923.03$ da AOAC (AOAC-923.03, 1997). 1,0 g de amostra seca foi incinerada em mufla (QUIMIS, Q318M24, Brasil), a $800^{\circ} \mathrm{C}$ por 4 horas. O teor de cinzas foi calculado pela equação 2.

$$
\% \text { Cinzas }=\frac{M c}{M_{A}} \times 100
$$

Sendo: $M_{C}$ : massa de cinzas (diferença entre a massa do cadinho contendo cinzas e este vazio) e $M_{A}$ : massa da amostra seca.

\subsubsection{Proteínas}

O teor de proteínas foi determinado pela metodologia Kjeldahl, segundo a técnica n926.86 da AOAC (AOAC-926.86, 2005). Esta técnica consiste de três etapas principais:

1) Digestão das proteínas da amostra: $0,3 \mathrm{~g}$ de amostra foram pesadas em tubo para digestão, em seguida foram adicionadas $2 \mathrm{~g}$ de mistura catalítica $\mathrm{CuSO}_{4}: \mathrm{Na}_{2} \mathrm{SO}_{4}$ (20:1) e $5 \mathrm{~mL}$ de $\mathrm{H}_{2} \mathrm{SO}_{4}$ concentrado a $400{ }^{\circ} \mathrm{C}$ em um digestor (Quimis, modelo Q327M, Brasil) para a geração de $\left(\mathrm{NH}_{4}\right)_{2} \mathrm{SO}_{4}$.

$$
\text { Amostra (Proteina) }+\mathrm{H}_{2} \mathrm{SO}_{4} \longrightarrow\left(\mathrm{NH}_{4}\right)_{2} \mathrm{SO}_{4}
$$

2) Neutralização e destilação: esta etapa foi realizada no equipamento semiautomático Kjeldahl (Quimis, Q328S21, Brasil). A amostra digerida foi adicionada 
de aproximadamente $25 \mathrm{~mL}$ de $\mathrm{NaOH}$ (50\%), para neutralização, e em seguida foi realizada a destilação $\left(75^{\circ} \mathrm{C}\right) . \mathrm{O} \mathrm{NH}_{3}$ destilado foi recolhido em uma solução de $4 \%$ $(\mathrm{m} / \mathrm{v})$ de $\mathrm{H}_{3} \mathrm{BO}_{3}$ contendo indicador vermelho de metila-verde de bromocresol. Desta maneira, foi recolhida uma solução de aproximadamente $70 \mathrm{~mL}$ de $\mathrm{NH}_{4} \mathrm{H}_{2} \mathrm{BO}_{3}$.

$$
\begin{aligned}
\left(\mathrm{NH}_{4}\right)_{2} \mathrm{SO}_{4}+2 \mathrm{NaOH} & \longrightarrow 2 \mathrm{NH}_{3}+\mathrm{Na}_{2} \mathrm{SO}_{4}+2 \mathrm{H}_{2} \mathrm{O} \\
\mathrm{NH}_{3}+\mathrm{H}_{3} \mathrm{BO} & \longrightarrow \mathrm{NH}_{4} \mathrm{H}_{2} \mathrm{BO}_{3}
\end{aligned}
$$

O indicador vermelho de metila-verde de bromocresol foi obtido da mistura de vermelho de metila $(0,1 \% \mathrm{~m} / \mathrm{v}$ em etanol) e verde de bromocresol $(0,1 \% \mathrm{~m} / \mathrm{v}$ em etanol) nas proporções de 2:5, respectivamente.

3) Titulação: nesta etapa, foi utilizado $\mathrm{HCl}(0,1 \mathrm{M})$ para titular a solução destilada que contém $\mathrm{NH}_{4} \mathrm{H}_{2} \mathrm{BO}_{3}$.

$$
\mathrm{NH}_{4} \mathrm{H}_{2} \mathrm{BO}_{3}+\mathrm{HCl} \longrightarrow \mathrm{H}_{3} \mathrm{BO}_{3}+\mathrm{NH}_{4} \mathrm{Cl}
$$

A determinação de teor de proteínas é baseada no teor de nitrogênio. $O$ teor de proteínas foi calculado segundo as equações 3 e 4 . Na equação 4 foi utilizado o fator de conversão de 6,25 . Na maioria dos alimentos o nitrogênio corresponde aproximadamente a $16 \%$ do peso da proteína, o que implica indiretamente que em $100 \mathrm{~g}$ de proteína tem-se $16 \mathrm{~g}$ de nitrogênio, e $100 / 16=6,25$, que corresponde ao fator de conversão de nitrogênio: proteína (N:P). Dessa maneira, quando a concentração de nitrogênio total é convertida em proteína utilizando-se o fator de conversão 6,25, considera-se que todo nitrogênio recuperado é proveniente, principalmente, da proteína e que a contribuição de substâncias nitrogenadas não proteicas, como nitrogênio inorgânico (nitrato, nitrito) e outras fontes de nitrogênio orgânico (nucleotídeos, ácidos nucléicos, aminoácidos livres, pequenos peptídeos, quitina, clorofila) são desprezíveis (GUIMARÃES; LANFER-MARQUEZ, 2005).

$$
\begin{aligned}
& \% N_{T}=\frac{\left(V_{a}-V_{b}\right) \times N_{1} \times 0,014 \times 100}{M} \\
& \% \text { P.B (b.u) }=\% N_{T} \times 6,25
\end{aligned}
$$

Sendo: \% $\mathrm{N}_{\mathrm{T}}$ : nitrogênio total, \% P.B $\mathrm{B}_{(\mathrm{b} . \mathrm{u})}$ : proteína bruta em base úmida, Va: volume $(\mathrm{mL})$ de $\mathrm{HCl}$ usado na titulação da amostra, $\mathrm{Vb}$ : volume $(\mathrm{mL})$ de $\mathrm{HCl}$ usado na titulação do branco, $\mathrm{N}_{1}$ : normalidade de $\mathrm{HCl}$ usado na titulação, $\mathrm{M}=\operatorname{massa}(\mathrm{g})$ de amostra seca. 


\subsubsection{Lipídeos}

Para a determinação de lipídeos foi utilizado o método de Bligh; Dyer, (1959) utilizando solventes como clorofórmio, metanol e água. Em béquer foram pesadas 3,0 g de amostra e adicionados $10 \mathrm{~mL}$ de clorofórmio, $20 \mathrm{~mL}$ de metanol e $8 \mathrm{~mL}$ de água deionizada, respectivamente. O béquer foi fechado com auxílio de papel filme e colocado sob agitação por 3 min. Ao terminar a agitação, adicionou-se $10 \mathrm{~mL}$ de clorofórmio e $10 \mathrm{~mL}$ de solução de sulfato de sódio 1,5\% gerando-se duas fases: aquosa e orgânica. $\mathrm{Na}$ fase orgânica estão os lipídeos presentes no material. Agita-se a mistura por mais 2 minutos, em seguida aguarda-se 30 minutos para que as camadas se separarem naturalmente em funil de decantação. São recolhidos $15 \mathrm{~mL}$ da camada inferior para um tubo de $30 \mathrm{~mL}$. Em seguida, $1 \mathrm{~g}$ de sulfato de sódio anidro foi adicionado e o tubo foi fechado e agitado para a retirada de resquícios de água. A amostra foi filtrada em papel de filtro e $5 \mathrm{~mL}$ do filtrado foram pesados em béquer de $50 \mathrm{~mL}$ previamente tarado. $\mathrm{O}$ béquer foi colocado em estufa à $80^{\circ} \mathrm{C}$ durante 30 minutos e quando o solvente foi totalmente evaporado, o resíduo que sobrou foi esfriado em dessecador e pesado. A porcentagem de lipídeos foi calculada de acordo com a equação 5.

$$
\% \text { Lipideos }_{(b . u)}=\frac{P \times 4 \times 100}{W}
$$

Sendo: $M_{L}$ : massa de lipídeos e $M_{A}$ : massa da amostra seca.

\subsubsection{Teor de fibra alimentar total}

O teor de fibra alimentar total foi determinado pelo método enzimático-gravimétrico $\mathrm{n}^{\mathrm{o}}$ 985.29 da AOAC, descrito por Prosky e Lee (1996), com modificações. Este método baseia-se na digestão enzimática das amostras, com objetivo de promover a hidrólise do amido e das proteínas presentes. Em uma primeira etapa, o amido foi hidrolisado usando a enzima $\alpha$ amilase, posteriormente em uma segunda etapa, a proteína foi hidrolisada pela ação da protease, e por último a amilose foi hidrolisada usando a enzima amiloglucosidase. Para tal, $1 \mathrm{~g}$ de amostra seca e desengordurada foi agitada com $50 \mathrm{~mL}$ de solução tampão fosfato $\mathrm{pH}=6$ por 30 minutos a temperatura ambiente e, por mais 30 minutos a $60{ }^{\circ} \mathrm{C}$. Em seguida, adicionou-se 100 $\mu \mathrm{L}$ de $\alpha$-amilase (A3306, Sigma Aldrish). A solução permaneceu em banho-maria a $100{ }^{\circ} \mathrm{C}$, sob vigorosa agitação, por 15 minutos e depois foi resfriada a temperatura ambiente. $\mathrm{O} \mathrm{pH}$ da 
amostra foi ajustado a 7,5 com aproximadamente $10 \mathrm{~mL}$ de $\mathrm{NaOH}(0,275 \mathrm{M})$. A amostra foi então aquecida sob constante agitação em banho a $60^{\circ} \mathrm{C}$. Em seguida, adicionou-se $100 \mu \mathrm{L}$ de solução de protease (50 mg de protease - Brauzyn ${ }^{\circledR}$ 100, ProzynBioSolutions - em $1 \mathrm{~mL}$ de solução tampão de fosfato $\mathrm{pH}=6$ ) e foi mantida em constante agitação por 30 minutos. $\mathrm{O} \mathrm{pH}$ foi ajustado a 4,0-4,6 com $10 \mathrm{~mL}$ de $\mathrm{HCl}(0,325 \mathrm{M})$. Em seguida, adicionou-se $300 \mu \mathrm{L}$ de solução enzimática de amilo-glucosidase (A9913, Sigma Aldrish) sob agitação por 30 minutos a $60{ }^{\circ} \mathrm{C}$ (temperatura da amostra controlada). Adicionou-se $280 \mathrm{~mL}$ de etanol (95\%) para precipitação da fibra solúvel, resfriou-se e deixou-se em repouso por 60 minutos a temperatura ambiente. Filtrou-se o sólido e procedeu-se a lavagem com $20 \mathrm{~mL}$ de etanol 78\%, $10 \mathrm{~mL}$ etanol $95 \%$ e finalmente duas vezes com $10 \mathrm{~mL}$ de acetona. A amostra foi seca em estufa a $105^{\circ} \mathrm{C}$ até massa constante. A determinação foi realizada em quadruplicada. Um dos duplicados foi utilizado para a determinação da proteína e o outro para a determinação da cinza para correção do teor de fibras. A determinação do teor de cinzas e proteínas foi realizada de acordo com as metodologias já descritas anteriormente.

Para o preparo da solução tampão de fosfato $(\mathrm{pH}=6)$ foi utilizado misturas de $500 \mathrm{~mL}$ de água com $438 \mathrm{~mL}$ de $\mathrm{NaH}_{2} \mathrm{PO}_{4}(0,2 \mathrm{M})$ e $61,5 \mathrm{~mL}$ de $\mathrm{Na}_{2} \mathrm{HPO}_{4}(0,2 \mathrm{M})$.

As fibras do branco (papel filtro sem amostra) foram determinadas utilizando a equação 6 :

$$
\mathrm{B}=\mathrm{Wrt}_{\mathrm{B}}-\mathrm{P}_{\mathrm{B}}-\mathrm{C}_{\mathrm{B}}
$$

Onde: B é a massa de fibras do branco (g), $\mathrm{Wrt}_{\mathrm{B}}$ é a massa do resíduo total gerado pelo branco $(\mathrm{g}), \mathrm{P}_{\mathrm{B}}$ é a massa de proteínas do branco depois do tratamento enzimático $(\mathrm{g}), \mathrm{C}_{\mathrm{B}}$ é a massa de cinzas do branco depois do tratamento enzimático $(\mathrm{g})$.

O cálculo do teor de fibra alimentar para cada amostra desengordurada foi calculado de acordo com a equação 7 :

$$
\text { Wfibra }_{\text {a.d }}=\left[\mathrm{Wrt}_{\mathrm{a} . \mathrm{d}}-\mathrm{P}-\mathrm{C}\right]-\mathrm{B}
$$

Onde: Wfibra.d, é a massa de fibra alimentar da amostra desengordurada (g); Wrta.d é a massa (g) do resíduo total da amostra desengordurada depois do tratamento enzimático; P é a massa (g) de proteínas do resíduo depois do tratamento da amostra desengordurada e C, é a massa ( $\mathrm{g}$ ) de cinzas do resíduo total depois do tratamento da amostra desengordurada.

O teor de fibra alimentar total foi calculado de acordo com a equação 8 e foi expresso em $g$ de fibra por $100 \mathrm{~g}$ amostra seca. 


$$
\% \operatorname{TDF}_{(\mathrm{b} . \mathrm{s})}=\frac{\text { Wfibra }_{\mathrm{a.d}}}{\mathrm{W}_{\mathrm{a} . \mathrm{d}}}[100-\% \text { Lipídeos } \quad \text { (b.s) }]
$$

Onde: $\% \mathrm{TDF}_{(\mathrm{b} . \mathrm{s})}$, é a porcentagem de fibra por $100 \mathrm{~g}$ de amostra seca; Wfibra a.d, é a massa de fibra alimentar da amostra desengordurada (g); $\mathrm{W}_{\text {a.d }}$ é a massa (g) de amostra desengordurada e \%Lipídeos(b.s) é a porcentagem de lipídeos de amostra em base seca.

\subsubsection{Amilose}

O teor de amilose foi determinado pelo método colorimétrico do iodo simplificado, de acordo com a metodologia proposta por Juliano (1971), adaptada por Martínez e Cuevas (1989). $0,2 \mathrm{~g}$ de amostra foram pesadas em um balão volumétrico de $100 \mathrm{~mL}$ e $1 \mathrm{~mL}$ de etanol (96\%) foi adicionado, e a mistura foi agitada para dissolver toda amostra. Em seguida foi acrescentado $9 \mathrm{~mL}$ de $\mathrm{NaOH}(1 \mathrm{~N})$ e realizado o aquecimento em banho-maria, a $100^{\circ} \mathrm{C}$, durante 9 minutos, para gelatinização do amido. Deixou-se esfriar por 30 minutos o balão. Lavou-se as paredes do balão com água destilada e completou-se o volume para $100 \mathrm{~mL}$ com posterior agitação. Pipetou-se $5 \mathrm{~mL}$ da solução obtida para um novo balão volumétrico de $100 \mathrm{~mL}$ e adicionou-se $1 \mathrm{~mL}$ de ácido acético $(1 \mathrm{M}), 2 \mathrm{~mL}$ da solução de iodo $(0,0001 \mathrm{~N})$ para formar o complexo amilose-iodo e completou-se o volume de $100 \mathrm{~mL}$ de solução. Deixou-se em repouso a solução por 30 minutos para fazer a leitura da absorvância em $\Lambda=610$. O valor da absorvância foi relacionado com uma curva padrão de amilose para determinar o teor de amilose na amostra. $\mathrm{O}$ teor de amilose foi calculado pela equação 9:

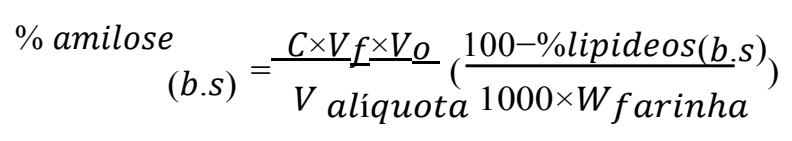

Sendo: \% amilose (b.s): teor de amilose em base seca ( $\mathrm{g}$ de amilose/100g de farinha), C: concentração da última diluição, Vf: volume da diluição final $(\mathrm{mL})$, Vo: volume da primeira diluição $(\mathrm{mL})$, Valíquota: volume da alíquota $(\mathrm{mL}), \%$ lipídeos(b.s): porcentagem de lipídeos da amostra total em base seca, $\mathrm{W}_{\text {farinha: }}$ massa de farinha na amostra seca $(\mathrm{g})$. 


\subsubsection{Distribuição do tamanho de partículas}

A distribuição do tamanho de partículas do resíduo e das farinhas isoladas pelos três métodos testados foram determinados por difração de laser com espalhamento estático de luz (DLS) através de um Difratômetro Laser (Beckman Coulter, LS 13320, EUA), em módulo tornado para análise de amostras secas.

\subsubsection{Microscopia eletrônica de varredura (MEV)}

O resíduo da extração de corante de urucum e as farinhas isoladas pelos três métodos testados tiveram a morfologia analisada por Microscopia Eletrônica de Varredura (MEV). Estes materiais foram acondicionados em dessecadores com sílica gel por sete dias para a retirada da umidade e foram colocados em suportes de alumínio e cobertos com ouro através de pulverização catódica por meio de um metalizador (Bal-Tec, SCD050 Sputter Coater, Fürstenstein-Liechtenstein). As micrografias das amostras foram obtidas em um Microscópio Eletrônico de Varredura (MEV), (Shimadzu, SS-550, Kyoto-Japão), sob voltagem de aceleração de $15 \mathrm{KV}$.

\subsubsection{Cor}

Os parâmetros de cor das amostras de resíduo de urucum, farinhas e farelos foram avaliados com auxílio de um colorímetro portátil MiniScan XE (Hunterlab, Riston, Virginia, EUA) de acordo com o método (HUNTERLAB, 1997). A análise foi feita em triplicata. Para determinar a cor, os valores de $\mathrm{L}^{*}, \mathrm{a}^{*}$ e $\mathrm{b}^{*}$ foram obtidos de acordo com as coordenadas da escala CIE Lab (Commission Internationale de 1'Eclairage $L^{*}, a^{*}, b^{*}$ ), baseado em uma representação numérica dos parâmetros de luz refletida no espectro visível (Figura 2.2). O parâmetro L* representa a luminosidade que varia de 0 a 100, sendo que valores mais próximos a 100, representam amostras mais claras e os valores próximos a 0 , as mais escuras. A cromaticidade é definida por a*, coordenada que varia do vermelho $\left(+\mathrm{a}^{*}\right)$ ao verde (-a*), e por $\mathrm{b}^{*}$, coordenada que varia do amarelo $\left(+\mathrm{b}^{*}\right)$ ao azul $\left(-\mathrm{b}^{*}\right)$. As medidas foram conduzidas em triplicata. A cor foi expressa como a diferença de cor total $\left(\Delta \mathrm{E}^{*}\right)$ e foi calculada pela equação 10: 


$$
\Delta \mathrm{E} *=\sqrt{\left(\Delta L^{*}\right)^{2}+\left(\Delta a^{*}\right)^{2}+\left(\Delta b^{*}\right)^{2}}
$$

Onde $\Delta \mathrm{E}^{*}$ : diferença total da amostra em relação a um padrão ou referência. $\Delta \mathrm{a}^{*}, \Delta \mathrm{b}^{*}$ e $\Delta \mathrm{L}^{*}$ são as diferenças entre os parâmetros das amostras e do branco $\left(a^{*}=-0,77, b^{*}=1,40, L^{*}=93,49\right)$.

Figura 2.2 - Esquema do sistema tridimensional representativo das coordenadas dos parâmetros de cor e da diferença de cor total $\left(\Delta \mathrm{E}^{*}\right)$
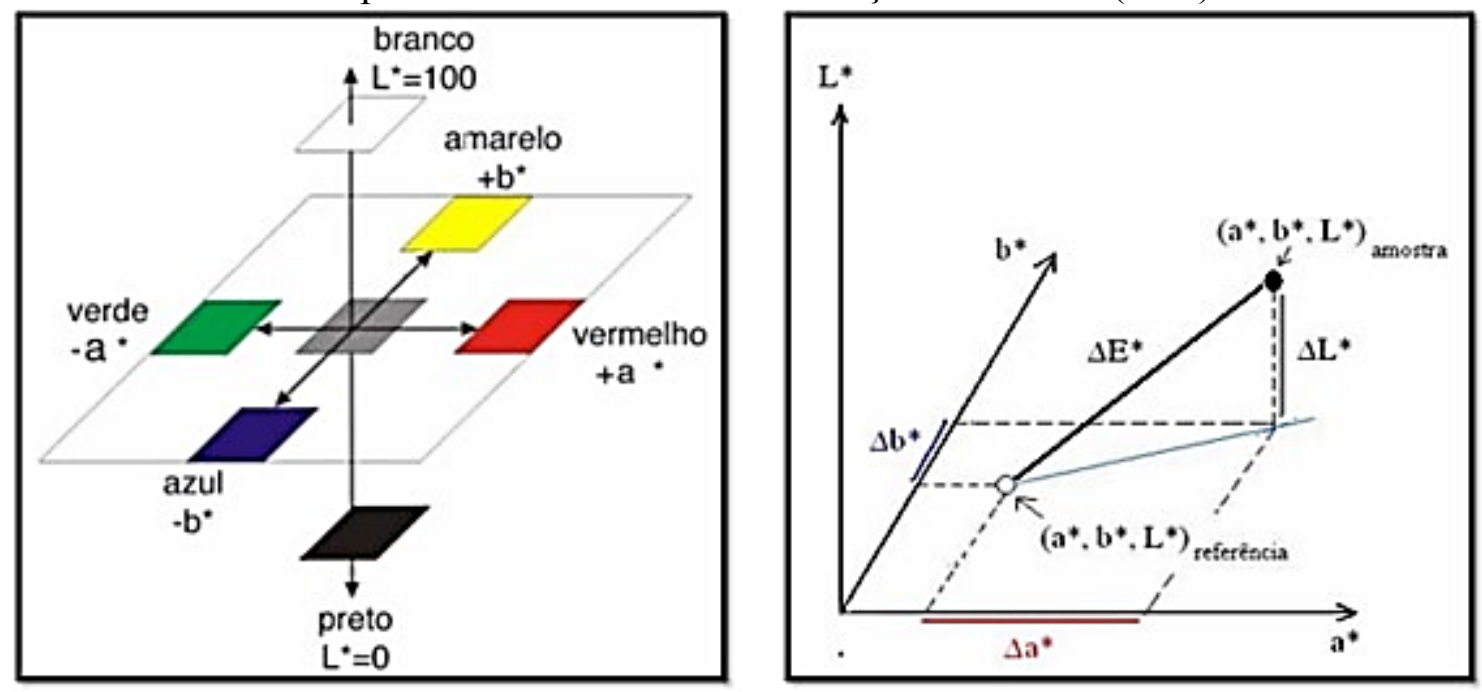

Fonte: Adaptado do Optical and Color, consultado em 23/05/2017 (http://www.smithersrapra.com/testing-services/by-material/plastics-and-polymer-physicaltesting/optical-and-colour) e (GONNET, 2001).

\subsubsection{Atividade Antioxidante}

A atividade antioxidante foi medida pelo método de captura do radical livre ABTS $^{\cdot+}$ (RUFINO et al., 2007). Pesou-se em béquer, aproximadamente $200 \mathrm{mg}$ de amostra, seguida pela adição de $2 \mathrm{~mL}$ de metanol. Esta mistura foi agitada à temperatura ambiente $\left(\sim 25^{\circ} \mathrm{C}\right)$ durante 3 h, na ausência de luz e depois filtrada usando papel filtro (Wathman $\mathrm{N}^{\circ} 4$ ) para obter o extrato.

$\mathrm{O}$ radical livre $\mathrm{ABTS}^{\bullet+}$ foi preparado a partir da reação de $5 \mathrm{~mL}$ de solução de estoque de ABTS $(7 \mathrm{mM})$ com $88 \mu \mathrm{L}$ da solução de persulfato de potássio $(140 \mathrm{mM})$. A solução foi armazenada no escuro à temperatura ambiente, durante 16 horas. Após este período, $1 \mathrm{~mL}$ da solução foi diluída em álcool etílico até se obter valores de absorvância de $0,70 \mathrm{~nm} \pm 0,05 \mathrm{~nm}$ a $734 \mathrm{~nm}$.

Finalmente, adicionou-se $3 \mathrm{~mL}$ do radical $\mathrm{ABTS}^{\circ+}$ a $30 \mu \mathrm{L}$ de extrato, e mantida em agitação por 6 min. Determinou-se a quantidade de radical $\mathrm{ABTS}^{{ }^{+}}{ }^{+}$restante por medida da 
absorvância a 734 nm usando um espectrofotômetro (Hewlett Packard HP 8453). Uma curva padrão foi preparada utilizando Trolox (antioxidante sintético), em concentrações de 10-2000 $\mu \mathrm{M}$. Os resultados da atividade antioxidante foram expressos em mg de equivalente Trolox (TE) / g de amostra.

\subsubsection{Carotenoides Totais e teor de Bixina}

A determinação do teor de carotenoides totais foi realizada de acordo com o método descrito por Gross, (1991). Assim, 0,1 g de amostra foi adicionado a $2 \mathrm{~mL}$ de uma solução contendo $200 \mathrm{mg} . \mathrm{L}^{-1}$ de hidroxitolueno butilado (BHT) em solvente acetona-etanol (1:1) e manteve-se sob vigorosa agitação, durante 1 hora. Em seguida, a amostra foi filtrada em papel filtro (Wathman $\mathrm{N}^{\circ} 4$ ), e foram feitas sucessivas lavagens utilizando a solução de acetona:etanol (1:1). O filtrado foi diluído até atingir $10 \mathrm{~mL}(\mathrm{Vf})$ de extrato em balão volumétrico. A absorvância do extrato foi medida na região de UV-visível em um espectrofotômetro (UV-M51 UV- Visível, Bel, Brasil) a 470nm. O solvente puro foi utilizado como branco. O teor de carotenoides totais foi calculado de acordo com a equação 11 e foi expresso em $\mu \mathrm{g}$ carotenoides por $\mathrm{g}$ de amostra seca.

$$
\mathrm{CT}=\frac{A x V_{f}}{M \times 100 \times A_{c m}^{106}}
$$

Sendo: CT: teor de carotenoides totais como $\mu \mathrm{g}$ equivalente em $\beta$-carotenos por cada $\mathrm{g}$ de amostra seca, A: absorvância $(\lambda=470 \mathrm{~nm}), \mathrm{V}_{\mathrm{f}}$ : volume da solução total $(\mathrm{mL}), A_{c m}^{1 \%}=2500$ corresponde ao coeficiente de absorvância específica para $\beta$-carotenos, $\mathrm{M}$ é a massa da amostra (g).

O teor de bixina, carotenoide principal presente nas sementes de urucum, foi determinado por HPLC (CTO-10ASVP, Shimadzu). A análise foi feita em triplicata. Aproximadamente $200 \mathrm{mg}$ de amostras de urucum foram pesadas em um béquer, seguido pela adição de $2 \mathrm{~mL}$ de metanol. A mistura foi agitada à temperatura ambiente $\left(\sim 25^{\circ} \mathrm{C}\right)$ durante 3 h, na ausência de luz. A amostra foi filtrada em papel filtro (Wathman $\mathrm{N}^{\circ} 4$ ) para obter o extrato. Em seguida, $50 \mu \mathrm{L}$ do extrato foi injetado nas seguintes condições: coluna C-18 (Luna da Phenomenex, 4,6 x $150 \mathrm{~mm}, 5 \mathrm{um}$ ), conjunto de detectores de diodo (Modelo: SPD M10AVP) 
(460 nm), loop $=20 \mu \mathrm{L}$, fluxo $=1,0 \mathrm{~mL} \cdot \mathrm{min}^{-1}$. A fase móvel utilizada foi de acetonitrila: ácido acético a 2\% (65:35). O padrão bixina foi adquirido da Sigma-Aldrich (95\%). As soluções padrão de bixina em metanol foram preparadas em diferentes concentrações $(0,17$ a 3,20 mg.L$\left.1, \mathrm{R}^{2}=0,98\right)$ para construção da curva de calibração. A curva de calibração foi estabelecida através da representação gráfica das áreas de pico em função da concentração de cada analito. O tempo de retenção da bixina contida no resíduo de urucum e nas farinhas foi 24 minutos.

\subsubsection{Compostos fenólicos totais}

O teor de compostos fenólicos totais (CFT) foi determinado pelo método colorimétrico de Folin-Ciocalteau, de acordo com o método descrito por Hillis; Swain (1959). A análise foi feita em triplicata. $0,1 \mathrm{~g}$ de amostra seca foi adicionada à $2 \mathrm{~mL}$ de metanol, sob agitação por $1 \mathrm{~h}$ e depois filtrado para obter o extrato. Em seguida, em $0,5 \mathrm{~mL}$ deste extrato foi adicionado a 8 $\mathrm{mL}$ de água e $0,5 \mathrm{~mL}$ da solução de Folin-Ciocalteu em meio aquoso na proporção 1: $7 \mathrm{e}$ mantido em agitação por 3 minutos com posterior adição de 1,0 mL de solução de carbonato de sódio $(0,5 \mathrm{M})$. Os tubos foram mantidos sob agitação por $10 \mathrm{~min}$ e depois foi medida a absorvância a $725 \mathrm{~nm}$ em um espectrofotômetro (UV-M51 UV-Visível, Bel, Brasil). O teor de CFT foi determinado utilizando uma curva padrão de ácido gálico ( 5 a $45 \mathrm{mgL}^{-1}$ ), expressos como mg de equivalente ácido gálico (EAG) por $100 \mathrm{~g}$ de amostra. A equação da curva padrão de $\mathrm{EAG}$ obtida foi $\mathrm{C}=161,89 \mathrm{~A}-0,0066$ com $\mathrm{R}^{2}=0,9898$, onde $\mathrm{C}$ é a concentração do $\mathrm{EAG}$ em $\mathrm{mgL}^{-1}$ e A é a absorvância da leitura da amostra. Foi utilizado um branco, composto por metanol e reagentes sem o extrato.

\subsubsection{Calorimetria diferencial de varredura (DSC)}

As temperaturas de gelatinização das farinhas isoladas foram determinadas por Calorimetria Diferencial de Varredura usando um DSC 2010 (TA Instruments, New Castle, DE, USA). As amostras $(\sim 1 \mathrm{mg})$ foram pesadas diretamente em cápsulas de alumínio (TA Instruments, pans, \#900793,901) e adicionada água deionizada (9 mg) usando uma micro seringa para produzir uma suspensão de amido de $10 \%(\mathrm{w} / \mathrm{w})$. As amostras foram hermeticamente seladas e deixadas em repouso durante 45 minutos a temperatura ambiente antes do aquecimento no DSC. O analisador DSC foi calibrado usando índio e um cadinho vazio como referência. Os cadinhos foram aquecidos a uma taxa de $10{ }^{\circ} \mathrm{C} / \mathrm{min}$ de 30 a $110{ }^{\circ} \mathrm{C}$, em 
ambiente inerte (45 mL/min de N2).

Foi utilizado, para referência, uma cápsula vazia, e o equipamento foi calibrado com amostra de índium $\left(\mathrm{Tm}=156,6^{\circ} \mathrm{C}\right.$ e $\Delta \mathrm{m}=28,71 \mathrm{~J} / \mathrm{g}$ ) (TA Instruments). As temperaturas do intervalo de gelatinização: $T_{i}$ (temperatura de início), $T_{p}$ (temperatura pico de gelatinização), $T_{f}$ (temperatura final) e $\Delta \mathrm{H}$ referido a entalpia de gelatinização foram obtidas pelo software Universal Analysis 2000 (TA Instruments, New Castle, Inglaterra).

\subsubsection{Difração de raios-X}

O resíduo da extração de corante de urucum e as farinhas isoladas tiveram os índices de cristalinidade determinados por difração de raios-X. As amostras foram previamente desidratadas em dessecador com sílica gel durante uma semana. Foram fixadas em suporte de alumínio e analisadas à temperatura ambiente, em um Difratômetro de Raios-X Siemens, (Siemens, modelo D5005, Baden-Württemberg, Alemanha), operando com filtro monocromático, radiação $\mathrm{K} \alpha$ de cobre, corrente de $30 \mathrm{~mA}$, voltagem de $40 \mathrm{KV}$ e velocidade de varredura de $0,02^{\circ}$ por segundo, com ângulo $2 \theta$ variando $2^{\circ}$ a $50^{\circ}$. O índice de cristalinidade (\%) dos materiais foi quantitativamente estimado como a razão entre a área cristalina para a área total do difratograma, seguindo o método de Nara; Komiya, (1983) usando o software Origin 8.1 (OriginLab Corporation, Massachusetts, EUA).

\subsubsection{Espectroscopia de absorção na região do infravermelho (FTIR)}

As análises espectroscópicas na região do infravermelho das amostras foram realizadas em um espectrofotômetro (Shimadzu, IR Prestige-21, Kyoto-Japão) com transformada de Fourier (ATR). As análises foram realizadas na região de 4000 a $400 \mathrm{~cm}^{-1}$, com resolução de 2 $\mathrm{cm}^{-1}$, com 20 varreduras.

\subsubsection{Análise estatística dos resultados}

Foram realizadas análise de variância (ANOVA) e o teste de Tukey de comparações múltiplas de médias, com nível de significância de $5 \%$ para avaliar a diferença significativa das propriedades do resíduo e das farinhas isoladas pelos métodos de moagem em meio neutro 
(WS), moagem em $\mathrm{pH}$ ácido (AS) e moagem em $\mathrm{pH}$ alcalino. As análises estatísticas foram realizadas utilizando o software Statistica 7.0: Basic Statistics and Tables.

\subsection{Resultados e Discussão}

\subsubsection{Composição Química}

O resíduo da extração de corante de urucum fornecido pela Firace, contêm 11,02 \pm 0,63\% de umidade (base úmida), 17,88 $\pm 0,93 \%$ de proteínas, 8,31 $\pm 0,62 \%$ de lipídeos, 19,52 $\pm 0,63 \%$ de fibras, $5,03 \pm 0,01 \%$ de cinzas e 49,26 $\pm 1,43 \%$ de amidos, $28,95 \pm 0,97 \%$ de amilose, teores em base seca. Os teores de proteínas, lipídeos e amidos do resíduo de urucum foram semelhantes aqueles reportados por outros autores na literatura (BRITO et al., 2015; CARVALHO; CARVALHO; MANTOVANI, 1991; PEDROSA; CIRNE; MAGALHÃES NETO, 1999; VALÉRIO et al., 2015). No entanto, o teor de fibras neste trabalho foi baixo quando comparado ao relatado por Utiyama; Miyada \& Figueiredo (2002) e Valério et al. (2015), 36,8\% e 28,5\%, respectivamente. As diferenças na composição química do resíduo de urucum podem ser devido aos métodos de extração de corantes utilizados nestes casos: óleo de soja ou solução alcalina de $\mathrm{KOH}$.

Os materiais obtidos do resíduo da extração de corante de urucum pelos métodos de isolamento de moagem em água (WS), ácido (AS) e alcalino (KS) também foram caracterizados em base a sua composição química, os resultados estão apresentados na Tabela 2.1, onde também estão apresentados os rendimentos dos métodos de extração utilizados.

Com relação ao isolamento de amido, a Tabela 2.1 mostra que os métodos (WS, AS ou KS) aqui utilizados não proporcionaram amido puro: os materiais isolados contêm entre 64,6 a $68,7 \%$ de amido, sendo então designados como farinha. Outros autores conseguiram isolar amidos mais puros quanto utilizaram os métodos WS, AS ou KS para isolar amido de mesocarpo de babaçu (94 a 98,8\% de amido) ou de outras fontes vegetais como maca root (87,8\% de amido), makal (96,7\% de amido), amido de sementes de Parota (84\% de amido) (ESTRADA-LEÓN et al., 2016a; MANIGLIA; TAPIA-BLÁCIDO, 2016; RONDÁNSANABRIA; FINARDI-FILHO, 2009; TORRUCO-UCO; BETANCUR-ANCONA, 2007).

Devemos aqui ressaltar que estes autores isolaram amido a partir de materiais integros, já nosso trabalho trata-se de uma tentativa em isolar amido de um resíduo resultante da extração de 
pigmento de urucum. Como apresentado na Tabela 2.1, nos farelos obtidos predomina-se fibras, 33,21 a 49,97\%, mas também contêm de 28 a 45\% de amido e menores teores de proteínas e lipídeos quando comparados à farinha. $\mathrm{O}$ alto teor de proteínas e lipídeos das farinhas isoladas pelos métodos WS, AS e KS podem explicar a baixa pureza em termos de amido deste material isolado. As proteínas e lipídeos podem ter impedido a entrada de água no material integral, dificultando a liberação de grânulos de amido.

Os métodos WS e AS permitiram obter maiores rendimentos em base seca na extração do amido (32 e 31\%, respectivamente) quando comparados ao método KS (19\%). Comportamento diferente foi observado na extração de amido de milho e amido do mesocarpo de babaçu (MANIGLIA; TAPIA-BLÁCIDO, 2016; PALACIOS-FONSECA et al., 2013), pois estes autores relataram maior rendimento no isolamento do amido quando usado o método alcalino.

Ao comparar os três métodos testados WS, AS e KS, observa-se pela Tabela 2.1 que o método de moagem alcalina (KS) reduziu o teor de proteína quanto o teor de lipídeos de forma mais efetiva do que os outros métodos, em $17,9 \%$ e 59,4\%, respectivamente. Isso porque as proteínas presentes nas sementes de urucum são solúveis em pH 12 (VALÉRIO et al., 2015) e os lipídeos são solúveis em solução alcalina (MANIGLIA; TAPIA-BLÁCIDO, 2016). Entretanto, o método AS permitiu obter farinha com menor teor de fibras quando comparado com o resíduo (de 19,5\% para 3,8\%) e foi mais eficaz que os métodos WS e KS, considerando que a celulose e a hemicelulose em meio ácido podem ter sofrido hidrólise, rendendo então uma farinha com menor teor de fibras (SUN et al., 2004; BRETT; WALDRON, 1990; VAN SOEST 1996). O método KS também produziu uma farinha com maior conteúdo de cinzas em comparação com as farinhas isoladas pelos métodos WS e AS. A solução de $\mathrm{NaOH}$ (pH 10) utilizada na extração em meio alcalino pode ter degradado e solubilizado estruturas que estariam aderidas aos grânulos de amido, permitindo assim a difusão de íons sódio para o interior dos grânulos de amido (ROONEY; SUHENDRO, 1999). Um comportamento semelhante foi relatado para o isolamento de amido a partir de milho por mergulho em solução de $\mathrm{NaOH}$ (PALACIOS-FONSECA et al., 2013).

O teor de amilose da farinha obtida por método KS foi maior do que os teores obtidos pelos métodos WS e AS. Correia e Beirão-da-Costa (2010) relataram que o teor de amilose está influenciado pela lixiviação/ degradação da amilose durante a extração do amido. $\mathrm{O}$ alto teor de amilose da farinha obtida por método alcalino, pode estar relacionada à hidrólise alcalina das regiões cristalinas do grânulo de amido, formada principalmente pela amilopectina, a qual 
pode ser degradada preferencialmente e de forma mais rápida que a amilose, e em decorrência há um aumento relativo da amilose como fração linear (PALACIOS-FONSECA et al., 2013; RIBEIRO; SERAVALLI, 2004). Palácios-Fonseca et al. (2013) também observaram o mesmo comportamento na extração do amido de milho em meio alcalino, mas Maniglia e TapiaBlácido (2016) obtiveram um comportamento inverso no isolamento de amido do mesocarpo de babaçu em meio alcalino. Neste sentido, pode-se dizer que o teor de amilose pode ser influenciado pelo método de isolamento utilizado, pela fonte botânica e pela presença de outros componentes como proteínas, fibras e lipídios. Segundo Moore et al. (1983), o amido pode ser classificado em relação ao seu teor de amilose em: amido normal 18-30\% de amilose), amido ceroso (aproximadamente 1\%) e amido de elevado teor de amilose (mais que 70\%). Portanto pode-se dizer que o amido isolado pelos métodos de moagem em água, ácido e alcalino são do tipo normal. A proporção de amilose e amilopectina é uma importante propriedade funcional, uma vez que a amilose é responsável pela formação e estabilidade de géis, enquanto a amilopectina formar géis com baixa tendência a retrogradação e maior viscosidade (BILIADERIS, 1991). Nas farinhas obtidas pelos métodos estudados há predominância de amilopectina. Entretanto, os farelos apresentaram menores teores de amilose quando comparados às farinhas independentemente do método utilizado. Comparando os métodos de extração, observa-se na Tabela 2.1 que o método de extração em meio neutro (água) não alterou a estrutura das fibras e a cristalinidade do grânulo de amido, portanto este método permitiu obter farinhas com menor teor de amilose. Como o farelo está composto principalmente por fibras e amido, o método de determinação de amilose para este tipo de material apresenta algumas deficiências, sendo difícil determinar a quantidade real de amilose presente. 
Tabela 2.1 - Composição química e rendimento de farinhas e farelos obtidos de resíduo da extração de corante de urucum por diferentes métodos

\begin{tabular}{|c|c|c|c|c|c|c|}
\hline \multirow[t]{2}{*}{ Composição } & \multicolumn{3}{|c|}{ Farinhas } & \multicolumn{3}{|c|}{ Farelos } \\
\hline & WS & $\mathbf{A S}$ & KS & WS & $\mathbf{A S}$ & KS \\
\hline Umidade $(\%) *$ & $11,21 \pm 0,25^{\mathrm{bA}}$ & $10,86 \pm 0,31^{\mathrm{bA}}$ & $12,52 \pm 0,04^{\mathrm{aA}}$ & $11,92 \pm 0,91^{\mathrm{aA}}$ & $9,94 \pm 0,42^{\mathrm{bB}}$ & $9,54 \pm 0,32^{\mathrm{bB}}$ \\
\hline Cinzas (\%) & $3,85 \pm 0,08^{\mathrm{bA}}$ & $3,49 \pm 0,01^{\mathrm{cB}}$ & $5,85 \pm 0,15^{\mathrm{aA}}$ & $4,18 \pm 0,52^{\mathrm{bA}}$ & $5,45 \pm 0,17^{\mathrm{aA}}$ & $5,33 \pm 0,65^{\mathrm{abA}}$ \\
\hline Lipídeos (\%) & $6,50 \pm 0,31^{\mathrm{aA}}$ & $6,93 \pm 0,11^{\mathrm{aA}}$ & $3,37 \pm 0,39^{\mathrm{bA}}$ & $4,27 \pm 0,90^{\mathrm{aB}}$ & $4,89 \pm 0,37^{\mathrm{aB}}$ & $3,61 \pm 0,47^{\mathrm{aB}}$ \\
\hline Proteínas (\%) & $17,43 \pm 0,36^{\mathrm{bA}}$ & $19,46 \pm 0,50^{\mathrm{aA}}$ & $14,68 \pm 0,21^{\mathrm{cA}}$ & $13,33 \pm 0,03^{\mathrm{aB}}$ & $10,85 \pm 1,01^{b B}$ & $10,80 \pm 0,38^{\mathrm{bB}}$ \\
\hline Fibras (\%) & $7,63 \pm 2,01^{\mathrm{aB}}$ & $3,79 \pm 1,07^{\mathrm{bB}}$ & $7,38 \pm 1,19^{\mathrm{aB}}$ & $33,21 \pm 5,83^{\mathrm{bA}}$ & $49,97 \pm 7,08^{\mathrm{aA}}$ & $48,43 \pm 7,09^{\mathrm{aA}}$ \\
\hline Amido** & $64,59 \pm 2,07^{\mathrm{bA}}$ & $66,33 \pm 1,22^{\mathrm{abA}}$ & $68,72 \pm 1,28^{\mathrm{aA}}$ & $45,01 \pm 5,99^{\mathrm{aB}}$ & $28,84 \pm 7,17^{\mathrm{bB}}$ & $31,83 \pm 7,15^{\mathrm{bB}}$ \\
\hline Amilose A** $^{*}$ & $23,87 \pm 0,21^{\mathrm{bA}}$ & $23,52 \pm 0,84^{\mathrm{bA}}$ & $27,84 \pm 1,93^{\mathrm{aA}}$ & $6,70 \pm 0,45^{\mathrm{aB}}$ & $13,64 \pm 0,13^{\mathrm{bB}}$ & $14,26 \pm 0,45^{\mathrm{cB}}$ \\
\hline Rendimento & 32 & 31 & 19 & 48 & 47 & 50 \\
\hline
\end{tabular}

*: Umidade, expressa em base úmida, $(\%=\mathrm{g} / 100 \mathrm{~g}$ amostra úmida), **: Amido obtido por diferença (100-cinzas-proteínas-lipídeos-fibra alimentar). ***: Amilose expressa em relação `a quantidade de amido, $(\%=\mathrm{g}$ amilose $/ 100 \mathrm{~g}$ amido $)$.

$\mathrm{a}, \mathrm{b}, \mathrm{c}$ : Letras minúsculas diferentes na mesma linha indicam que há diferença estatística significativa entre as amostras segundo o teste de Tukey $(\mathrm{p}<0,005)$.

A, B: Letras maiúsculas diferentes na mesma linha indicam que há diferença estatística significativa entre as amostras segundo o teste de Tukey $(p<0,005)$.

(WS): moagem em água, (AS): moagem em pH ácido, (KS): moagem em pH alcalino. 


\subsubsection{Cor}

O resíduo da extração de corante de urucum, as farinhas isoladas pelos métodos de moagem em meio água (WS), moagem em pH ácido (AS) e moagem em pH alcalino e os correspondentes farelos apresentaram diferentes tons de vermelho, dependendo da técnica de isolamento empregada (Fig. 2.3).

Figura 2.3 - Resíduo da extração de corante de urucum, farinhas e farelos obtidos nos métodos por moagem em água (WS), moagem em $\mathrm{pH}$ ácido (AS) e moagem em $\mathrm{pH}$ alcalino $(\mathrm{KS})$

\section{Resíduo da extração de corante de urucum}
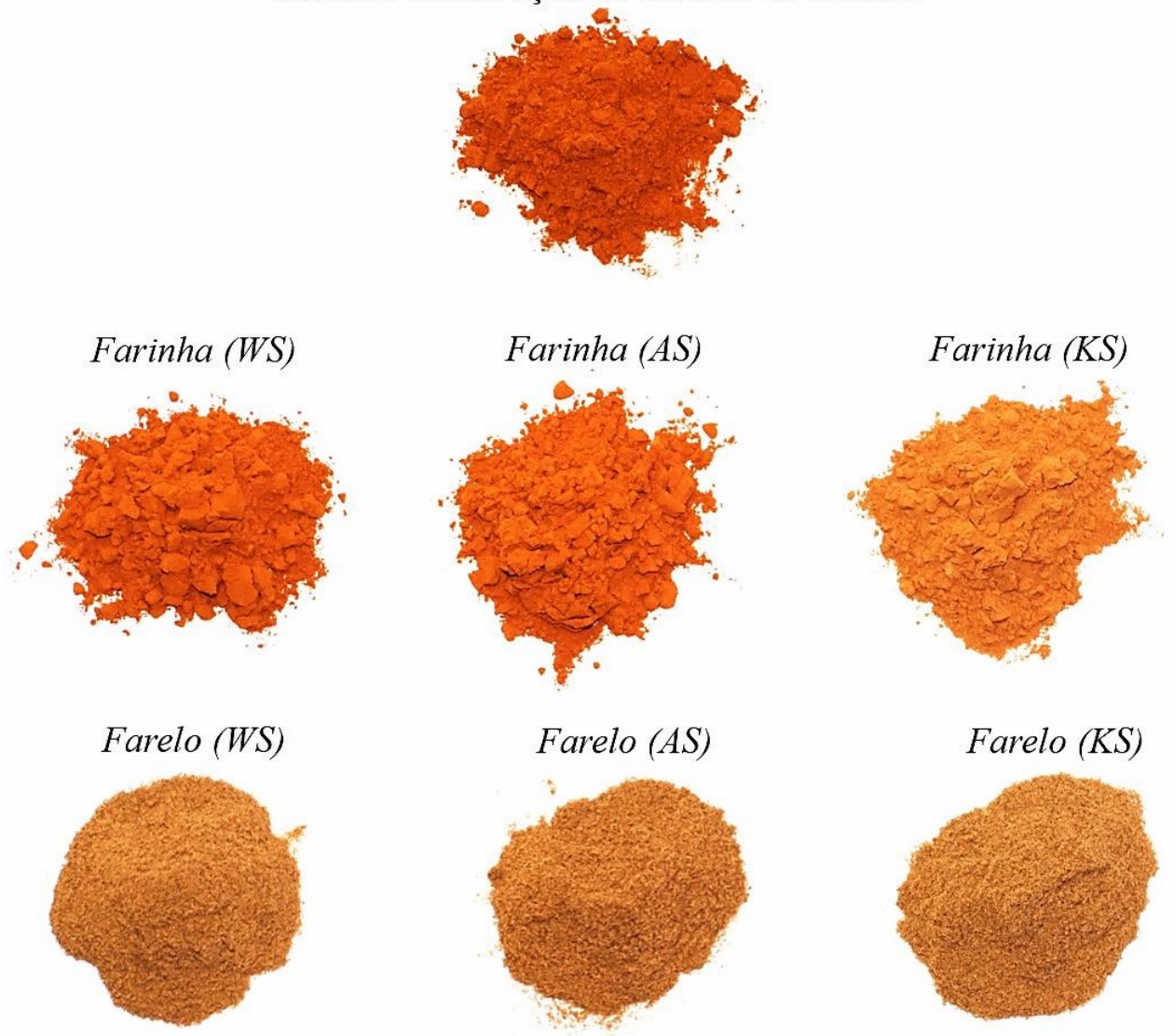

Fonte: Fotografia da autora.

A Tabela 2 apresenta os parâmetros de cor $\left(L^{*}, a^{*}, b^{*}\right)$ e as diferenças de cor $\left(\Delta E^{*}\right)$ do resíduo de urucum e dos materiais produzidos (farinhas e farelos). O resíduo de urucum mostrou menor luminosidade $\left(<\mathrm{L}^{*}\right)$ que as farinhas e semelhante aos farelos. 
As farinhas apresentaram tons maiores de vermelho $(>\mathrm{a} *(+))$ e amarelo $(>\mathrm{b} *(+))$ e maior diferença de cor $\left(>\Delta \mathrm{E}^{*}\right)$ do que o farelo, independentemente do método de isolamento utilizado. Este resultado indicou que os carotenoides responsáveis pela cor presente no resíduo de extração de pigmento de urucum permaneceram nas farinhas isoladas, possivelmente recobrindo a superfície dos grânulos de amido presentes nestas farinhas e associados às proteínas e lipídios.

O método de moagem em $\mathrm{pH}$ alcalino permitiu obter farinha com maior luminosidade e valores mais baixos dos parâmetros a * e b * em comparação com os materiais obtidos em isolamento pelos outros métodos. $\mathrm{O} \mathrm{pH}$ alcalino (solução de $\mathrm{NaOH}$ ) pode provocar a saponificação da bixina (responsável pela cor vermelha), produzindo a norbixina (de cor amarela) e esta durante processo de neutralização do $\mathrm{pH}$ é perdida por ser solúvel em água (MORTENSEN, 2006). Já o método de moagem em pH ácido produziu farinha com tons mais intensos de vermelho e amarelo que os outros métodos, possivelmente pela ação antioxidante do ácido ascórbico, utilizado na solução ácida, o qual evitou a perda de pigmentos de urucum ao longo do processo de isolamento de amido. 
Tabela 2.2 - Parâmetros de cor $\left(\mathrm{L}^{*}, \mathrm{a}^{*}, \mathrm{~b}^{*}\right)$ e diferença de cor $\left(\Delta \mathrm{E}^{*}\right)$ de resíduo da extração de corante de urucum, farinhas e farelos obtidos por

\begin{tabular}{|c|c|c|c|c|c|}
\hline Amostras & Método & $\mathrm{L}^{*}$ & $\mathrm{a}^{*}$ & $\mathrm{~b}^{*}$ & $\Delta \mathrm{E}^{*}$ \\
\hline Resíduo de Urucum & & $43,00 \pm 0,19$ & $22,21 \pm 0,10$ & $29,00 \pm 0,07$ & $61,41 \pm 0,10$ \\
\hline \multirow{3}{*}{ Farinhas } & WS & $46,49 \pm 0,25^{\mathrm{bA}}$ & $24,65 \pm 0,22^{\mathrm{bA}}$ & $29,78 \pm 0,38^{\mathrm{bA}}$ & $60,47 \pm 0,42^{\mathrm{bA}}$ \\
\hline & AS & $46,52 \pm 0,47^{\mathrm{bA}}$ & $28,39 \pm 0,23^{\mathrm{aA}}$ & $32,71 \pm 0,32^{\mathrm{aA}}$ & $63,57 \pm 0,38^{\mathrm{aA}}$ \\
\hline & $\mathrm{KS}$ & $52,44 \pm 0,17^{\mathrm{aA}}$ & $22,12 \pm 0,12^{\mathrm{cA}}$ & $27,51 \pm 0,21^{\mathrm{cA}}$ & $63,22 \pm 0,14^{\mathrm{aA}}$ \\
\hline \multirow{3}{*}{ Farelos } & WS & $42,56 \pm 0,51^{\mathrm{cB}}$ & $11,22 \pm 0,71^{\mathrm{abB}}$ & $18,10 \pm 0,24^{\mathrm{bB}}$ & $47,59 \pm 0,55^{\mathrm{bB}}$ \\
\hline & AS & $44,35 \pm 0,06^{\mathrm{bB}}$ & $10,61 \pm 0,12^{\mathrm{bB}}$ & $17,69 \pm 0,11^{\mathrm{bB}}$ & $48,91 \pm 0,10^{\mathrm{bB}}$ \\
\hline & $\mathrm{KS}$ & $46,67 \pm 0,62^{\mathrm{aB}}$ & $11,63 \pm 0,58^{\mathrm{aB}}$ & $19,22 \pm 0,69^{\mathrm{aB}}$ & $51,80 \pm 0,94^{\mathrm{aB}}$ \\
\hline
\end{tabular}

a,b: letras minúsculas diferentes na mesma coluna indicam que há diferença estatística significativa entre os métodos de extração (Tukey, $\mathrm{p}<0,05$ ). A, B: Letras maiúsculas diferentes na mesma coluna indicam que há diferença estatística significativa entre as amostras segundo o teste de Tukey $(\mathrm{p}<0,005)$.

$\mathrm{L}^{*}$, coordenada de parâmetros de luminosidade que variam de 0 (preto) a 100 (branco).

$a^{*}$, coordenada que varia do vermelho $\left(+a^{*}\right)$ ao verde $\left(-a^{*}\right)$.

$\mathrm{b}^{*}$ : coordenada que varia do amarelo $\left(+\mathrm{b}^{*}\right)$ ao azul $\left(-\mathrm{b}^{*}\right)$.

$\Delta \mathrm{E}^{*}$ : diferença de cor comparado com uma referência (branco).

(WS): moagem em água, (AS): moagem em pH ácido, (KS): moagem em $\mathrm{pH}$ alcalino. 


\subsubsection{Compostos fenólicos totais, carotenoides totais, teor de bixina e atividade antioxidante}

A Tabela 2.3 apresenta os teores de compostos fenólicos totais, carotenoides totais, teor de bixina e atividade antioxidante do resíduo da extração de corante de urucum, das farinhas isoladas pelos métodos de moagem em meio neutro, moagem em $\mathrm{pH}$ ácido, moagem em $\mathrm{pH}$ alcalino e dos correspondentes farelos. Nesta tabela observa-se que as farinhas contêm importante teor de compostos fenólicos e carotenoides, sendo estes últimos responsáveis pela coloração avermelhada deste material, como mostrado na análise de cor (Tabela 2.2). Como os teores destes compostos nas farinhas foram significativos e em valores quase semelhantes ao resíduo de urucum, confirma-se que estes compostos ficaram retidos nos grânulos de amido presentes na farinha dificultando também a liberação destes grânulos nos três meiosutilizados.

Por outro lado, a farinha isolada pelo método em $\mathrm{pH}$ ácido apresentou maior teor de compostos fenólicos totais do que os métodos em água e em $\mathrm{pH}$ alcalino. Segundo Angelo e Jorge (2007) os compostos fenólicos quando presentes em vegetais, podem estar em formas livres ou complexados a açúcares e proteínas. Segundo isto, o maior teor de proteínas presentes no amido isolado por moagem em meio ácido (Tabela 2.1) pode ter permitido a maior retenção destes compostos na farinha. Por outro lado, o método de moagem alcalina pode ter causado a oxidação dos compostos fenólicos presentes no resíduo de urucum obtendo-se farinha com menor teor de compostos fenólicos do que os métodos de moagem em pH ácido e em água. $\mathrm{O}$ farelo resultante do isolamento pelo método em $\mathrm{pH}$ ácido também apresentou maior teor de compostos fenólicos, o qual pode ser justificado pelo maior teor de fibras neste material, e possivelmente pelo maior teor de lignina, que contribuiu com o maior teor de compostos fenólicos do farelo (BRETT; WALDRON, 1990, ANGELO; JORGE, 2007). Por outro lado, o método de moagem em $\mathrm{pH}$ alcalino empregando-se hidróxido de sódio contribuiu com a solubilização de uma grande parte da lignina (OH et al., 2005), isto justifica o baixo teor de compostos fenólicos do farelo resultante do isolamento pelo método em $\mathrm{pH}$ alcalino.

Com relação ao conteúdo de carotenoides, observa-se na Tabela 2.3 que as farinhas extraídas pelos métodos de moagem em meio neutro, em $\mathrm{pH}$ ácido e em $\mathrm{pH}$ alcalino apresentaram maior teor de carotenoides do que resíduo de urucum. Entretanto, os farelos obtidos no processo apresentaram baixos teores de carotenoides quando comparados ao resíduo e as farinhas. Comparando os métodos de isolamento, observa-se que isolamento por moagem em $\mathrm{pH}$ ácido permitiu obter farinha com maior teor de carotenoides, enquanto pelo método em 
pH alcalino provocou perdas de carotenoides na farinha. Como os carotenoides são compostos lipossolúveis sabe-se que o meio alcalino solubiliza compostos lipídicos produzindo perdas dos carotenoides no processo de isolamento utilizado.

Os teores de bixina das farinhas isoladas pelos três métodos estudados foram semelhantes aos encontrados no resíduo de urucum. Portanto, os métodos de isolamento por moagem em água, em meio ácido e em meio alcalino não conseguiram remover a bixina presente no resíduo, e esta continuou retida nos grânulos de amido. Sabe-se que a bixina é insolúvel em água e pode formar complexos com proteínas e com a amilose que estão presentes no amido justificando sua presença na farinha isolada após os processos de moagem, peneiragem e centrifugação utilizando soluções aquosas em $\mathrm{pH}$ neutro, $\mathrm{pH}$ ácido e $\mathrm{pHalcalino}$ (BOBBIO; BOBBIO, 1992). O método por moagem em $\mathrm{pH}$ alcalino pode ter causado a saponificação da bixina produzindo o ácido dicarboxílico, a norbixina, causando uma ligeira diminuição do teor de bixina na farinha, como pode ser observada na Tabela 2.3 (PIMENTEL; STRINGHETA, 1999).

Os compostos fenólicos e carotenoides presentes nas farinhas isoladas por métodos de moagem em meio neutro, moagem em $\mathrm{pH}$ ácido e moagem em $\mathrm{pH}$ alcalino podem atuar como antioxidantes proporcionando esta característica a este material. Esta propriedade antioxidante das farinhas foi verificada pelo método de radical $\mathrm{ABTS}^{\circ}{ }^{\circ}$. Assim, foi confirmada que as farinhas extraídas pelos três métodos apresentaram atividade antioxidante, sendo maior a atividade antioxidante na farinha obtida pela moagem em $\mathrm{pH}$ ácido devido ao maior teor de compostos fenólicos e carotenoides totais deste material. Como neste método foi empregado ácido ascórbico, um antioxidante que pode ter evitado a oxidação dos compostos fenólicos, reforçando a propriedade antioxidante. Entretanto, o método em $\mathrm{pH}$ alcalino causou uma perda da atividade antioxidante devido à maior remoção dos carotenoides e oxidação dos compostos fenólicos. 
Tabela 2.3 - Compostos fenólicos totais, carotenoides totais, teor de bixina e atividade antioxidante (AA) em resíduo da extração de corante de

\begin{tabular}{|c|c|c|c|c|c|}
\hline Amostras & Métodos & $\begin{array}{l}\text { Compostos fenólicos totais } \\
\text { (mg de GAE/100g de amostra) }\end{array}$ & $\begin{array}{c}\text { Carotenoides totais } \\
\text { (ug carotenoides/g de } \\
\text { amostra) }\end{array}$ & $\begin{array}{c}\text { Bixina } \\
\text { (g bixina/100g de amostra) }\end{array}$ & $\begin{array}{c}\text { AA } \\
\text { (mg de TE/g de amostra) }\end{array}$ \\
\hline \multirow[t]{2}{*}{$\begin{array}{l}\text { Resíduo de } \\
\text { urucum }\end{array}$} & & $1141,16 \pm 7,73$ & $523,82 \pm 1,23$ & $12,16 \pm 0,25$ & $2,02 \pm 0,26$ \\
\hline & WS & $1454,93 \pm 36,18^{\mathrm{bA}}$ & $716,95 \pm 8,67^{\mathrm{bA}}$ & $13,01 \pm 0,59^{\mathrm{aA}}$ & $3,07 \pm 0,03^{\mathrm{bA}}$ \\
\hline \multirow[t]{3}{*}{ Farinha } & AS & $1578,83 \pm 45,89^{\mathrm{aA}}$ & $780,21 \pm 0,69^{\mathrm{aA}}$ & $11,06 \pm 0,30^{\mathrm{bA}}$ & $3,61 \pm 0,54^{\mathrm{aA}}$ \\
\hline & $\mathrm{KS}$ & $1306,60 \pm 10,13^{\mathrm{cA}}$ & $549,38 \pm 3,12^{\mathrm{cA}}$ & $11,32 \pm 0,30^{\mathrm{bA}}$ & $1,92 \pm 0,29^{\mathrm{cA}}$ \\
\hline & WS & $768,59 \pm 10,65^{\mathrm{bB}}$ & $280,00 \pm 1,15^{\mathrm{aB}}$ & $3,00 \pm 0,13^{\mathrm{bB}}$ & $0,66 \pm 0,25^{\mathrm{aB}}$ \\
\hline \multirow[t]{2}{*}{ Farelos } & AS & $1198,04 \pm 17,59^{\mathrm{aB}}$ & $201,46 \pm 3,61^{\mathrm{cB}}$ & $4,65 \pm 0,19^{\mathrm{aB}}$ & $0,80 \pm 0,07^{\mathrm{aB}}$ \\
\hline & KS & $713,01 \pm 1,87^{\mathrm{cB}}$ & $229,81 \pm 6,19^{\mathrm{bB}}$ & $3,09 \pm 0,18^{\mathrm{bB}}$ & $0,97 \pm 0,46^{\mathrm{aB}}$ \\
\hline
\end{tabular}

$\overline{\text { a,b,c: letras minúsculas diferentes na mesma coluna indicam que há diferença estatística significativa entre os métodos de extração (Tukey, } \mathrm{p}<}$ $0,05)$. A, B: Letras maiúsculas diferentes na mesma coluna indicam que há diferença estatística significativa entre as amostras segundo o teste de Tukey $(\mathrm{p}<0,005)$.

(WS): moagem em água, (AS): moagem em pH ácido, (KS): moagem em pH alcalino 


\subsubsection{Distribuição do tamanho de partículas}

A Figura 2.4 mostra a distribuição do tamanho de partículas do resíduo da extração de corante de urucum, farinhas isoladas pelos métodos de moagem em água, moagem em $\mathrm{pH}$ ácido e moagem em $\mathrm{pH}$ alcalino.

Figura 2.4 - Distribuição do tamanho das partículas do resíduo da extração de corante de urucum e farinhas isoladas por moagem em água (WS), moagem em $\mathrm{pH}$ ácido (AS) e moagem em $\mathrm{pH}$ alcalino (KS)

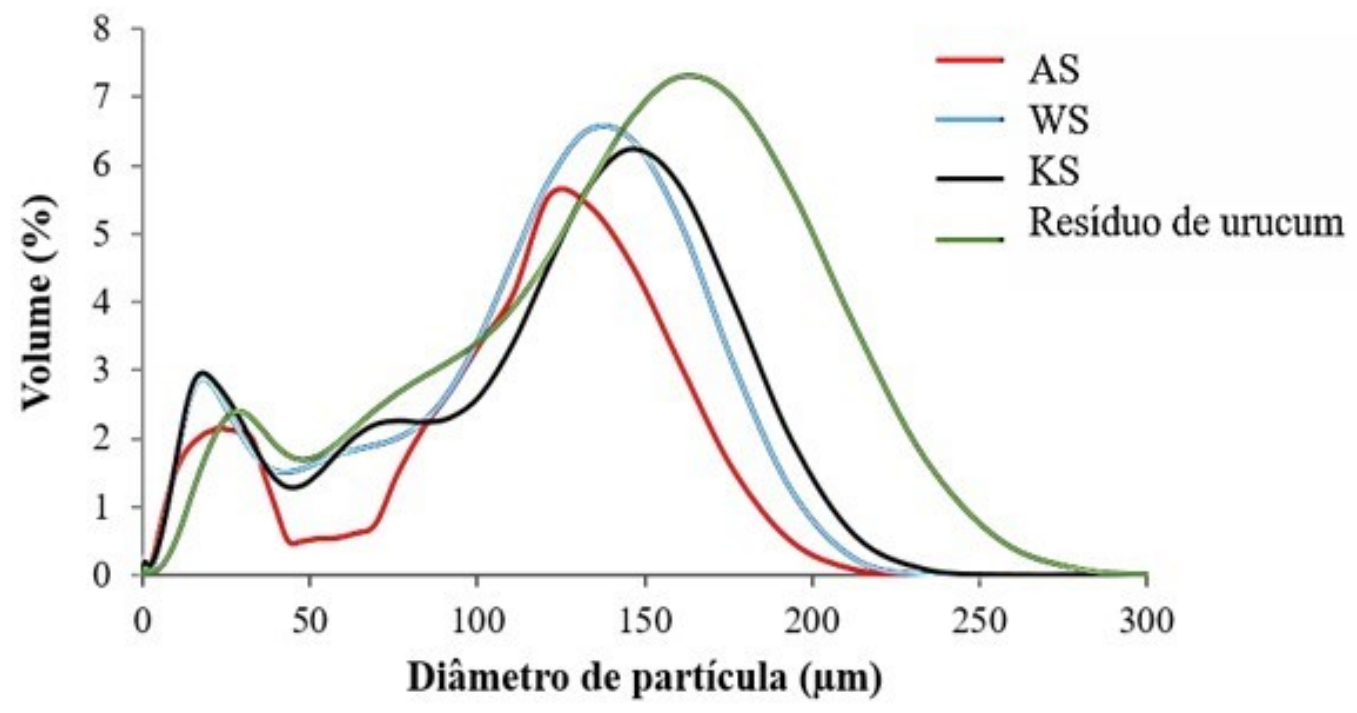

O resíduo da extração de pigmento de urucum exibiu distribuição de tamanho de partículas bimodal, com dois picos: o principal emergiu a $160 \mu \mathrm{m}$, e outro apareceu a $38 \mu \mathrm{m}$. Os métodos de moagem em água (WS) e moagem em pH ácido (AS) produziram farinhas com distribuição de tamanho de partícula bimodal. O pico principal correspondeu a um tamanho médio de $133 \mu \mathrm{m}$ e $121 \mu \mathrm{m}$, respectivamente, e houve um pico menor a $20 \mu \mathrm{m}$ e $22 \mu \mathrm{m}$, respectivamente (Figura 2.4). Já o método de moagem em $\mathrm{pH}$ alcalino permitiu obter uma farinha com distribuição de tamanho de partícula polimodal com um pico médio principal de $147 \mu \mathrm{m}$, um pico menor a $76 \mu \mathrm{m}$ e um terceiro pico a $20 \mu \mathrm{m}$ de tamanho médio de partícula. Essa variação no tamanho das partículas isoladas pelo método alcalino indicou maior formação de aglomerados de grânulos de amido nesta farinha. De acordo com Pelissari et al. (2012) a aglomeração dos grânulos de amido pode ser devido ao tratamento químico com $\mathrm{NaOH}$ que remove compostos químicos durante o processo. Neste trabalho, a agregação dos grânulos de amido foi justificada pela lixiviação da amilose, formação de interações amido-proteína e amido-lipídeo. Maniglia e Tapia-Blácido (2016) relataram variação no tamanho de partícula e 
presença de grânulos de amido aglomerados durante isolamento alcalino. Já os tamanhos de partícula variando de 20 a $22 \mu \mathrm{m}$ podem estar relacionados à presença de grânulos de amido liberados e soltos na farinha.

Como os métodos de isolamento de amido testados neste trabalho não permitiram obter amido puro e sim uma farinha com alto teor de amido $(64,6$ a 68,7\%), a distribuição de tamanho de partícula apresentou um maior pico principal de 121 a $147 \mu \mathrm{m}$ ao comparar com o amido isolado de mesocarpo de babaçu que apresentou pico em de $13 \mu \mathrm{m}$ pelos métodos WS ou KS (MANIGLIA; TAPIA-BLÁCIDO, 2016), o amido isolado de babana tem pico principal em 47,3 $\mu \mathrm{m}$ pelo método WS (PELISSARI et al., 2012), e o amido isolado de castanheiros com pico principal em 9-13 $\mu$ m pelo método KS (CORREIA; BEIRÃO-DA-COSTA, 2012).

\subsubsection{Morfologia por Microscopia Eletrônica de Varredura (MEV)}

As Figuras 2.5, 2.6 e 2.7 mostram as micrografias obtidas por MEV do resíduo da extração de corante de urucum, as farinhas isoladas pelos métodos de moagem em água, em pH ácido e em $\mathrm{pH}$ alcalino, e seus respectivos farelos. A Figura 2.5 mostra a microestrutura do resíduo de urucum, na qual pode ser observado que os grânulos de amido encontram-se aprisionados formando estruturas de maior tamanho. As proteínas, lipídeos, carotenoides e fibras presentes no resíduo de urucum devem ser as responsáveis pela formação destes aglomerados.

Por outro lado, na Figura 2.6 podemos observar que os métodos de isolamento utilizados neste trabalho removeram parcialmente as proteínas, lipídeos, carotenoides e fibras que inicialmente estavam aderidos aos grânulos de amido (Figura 2.5). Entretanto, nestas micrografias observa-se ainda a presença de aglomerados de grânulos de amido, e grânulos de amido cujas superfícies apresentam estruturas fibrosas e recobertas também com outros compostos como proteínas e lipídeos, que favorecem a aglomeração dos grânulos obtendo-se estruturas com diferentes tamanhos médios de partículas (Figura 2.4). Estas microestruturas observadas nas farinhas confirmam a composição centesimal mostrada na Tabela 2.1 e distribuição do tamanho de partícula mostrada na Figura 2.4. Nas micrografias da Figura 2.6 também pode ser observado que a farinha apresenta grânulos de amido livres com diâmetros médios de 15 a $18 \mu \mathrm{m}$ e formato ovais, esféricos, elipsóides e triangulares. As formas triangulares apresentam-se como a união de 3 grânulos envoltos por uma membrana. Para amidos de outras fontes, tais como, milho, mandioca, batata-doce, foram relatados diâmetros 
que variaram de 10,6 a $33 \mu \mathrm{m}$ (HERNÁNDEZ-MEDINA et al., 2008; MEDINA; SALAS, 2008).

As microestruturas dos farelos mostram a presença de grânulos de amido confirmando a composição centesimal apresentada na Tabela 2.1. O farelo está composto principalmente de estruturas fibrosas, onde os grânulos de amido encontram-se aprisionados possivelmente a proteínas e lipídeos (Figura 2.7).

Figura 2.5 - Micrografias obtidas por MEV do resíduo de urucum
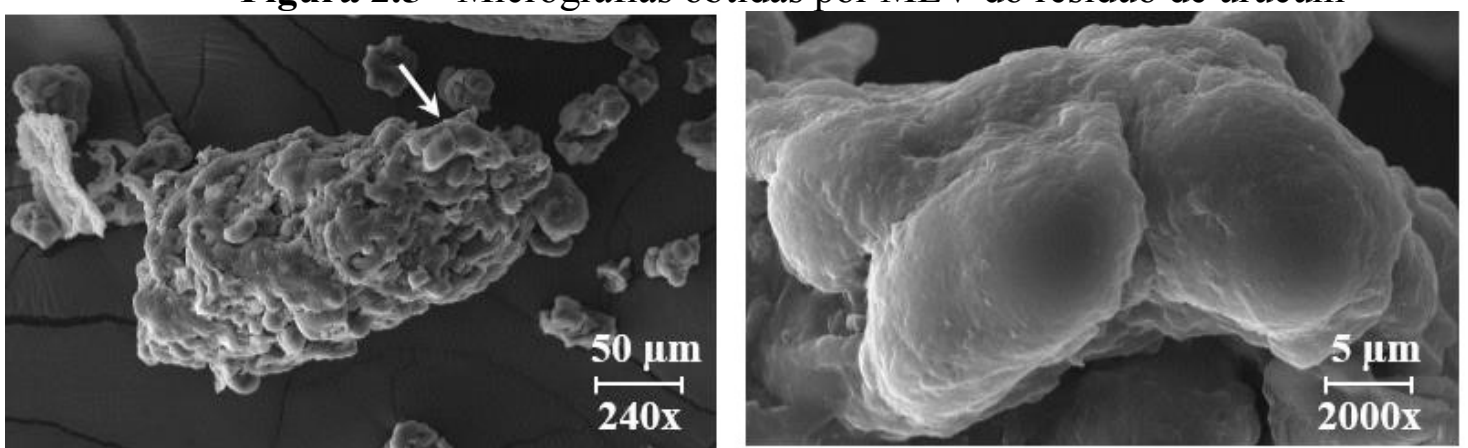
Figura 2.6 - Micrografias obtidas por MEV das farinhas isoladas por (A-B) moagem em água, (C-D) moagem em $\mathrm{pH}$ ácido, (E-F) moagem em $\mathrm{pH}$ alcalino
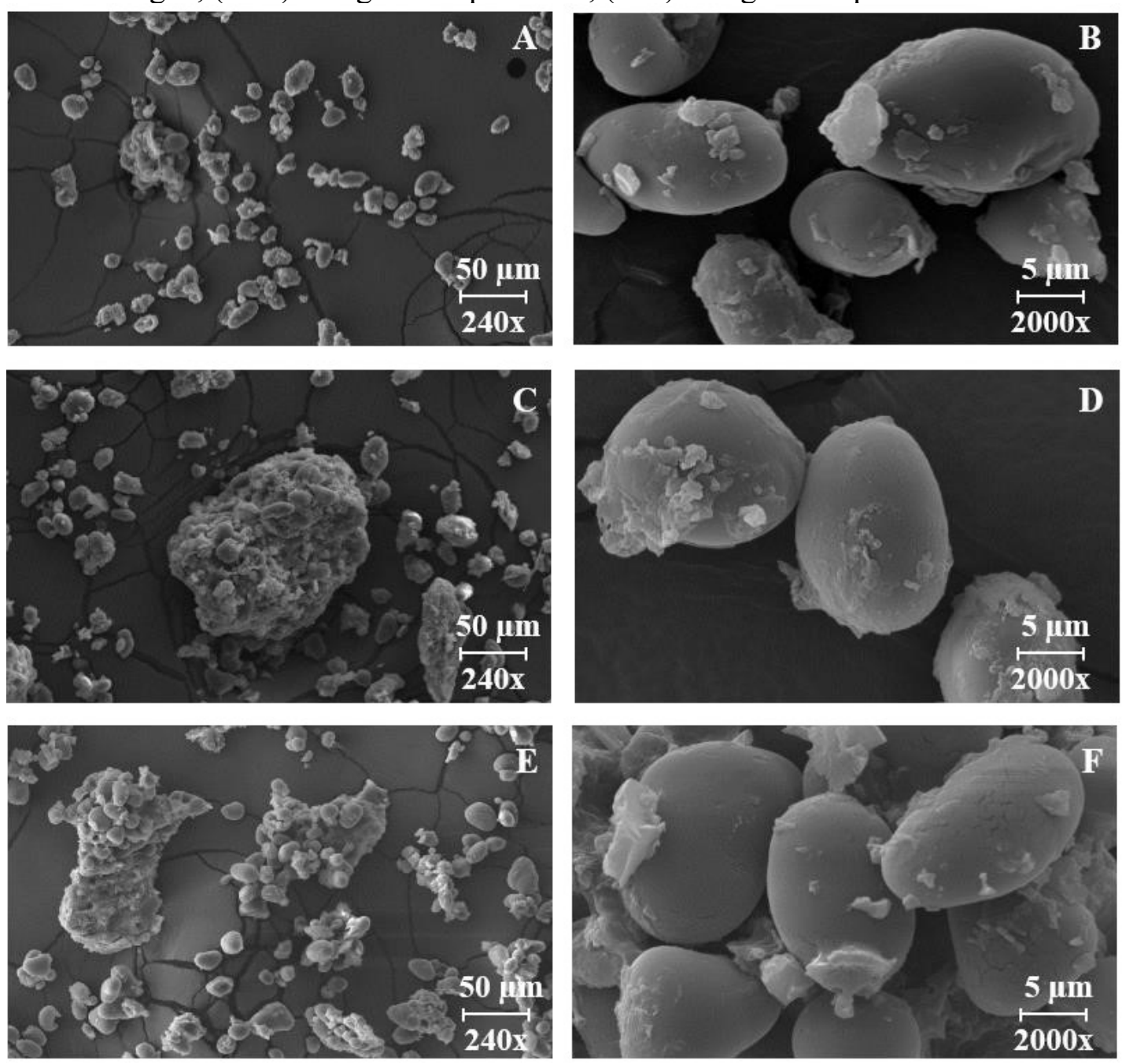
Figura 2.7 - Micrografias obtidas por MEV dos farelos resultantes do isolamento por (A-B) moagem em água, $(\mathrm{C}-\mathrm{D})$ moagem em $\mathrm{pH}$ ácido, $(\mathrm{E}-\mathrm{F})$ moagem em $\mathrm{pH}$ alcalino
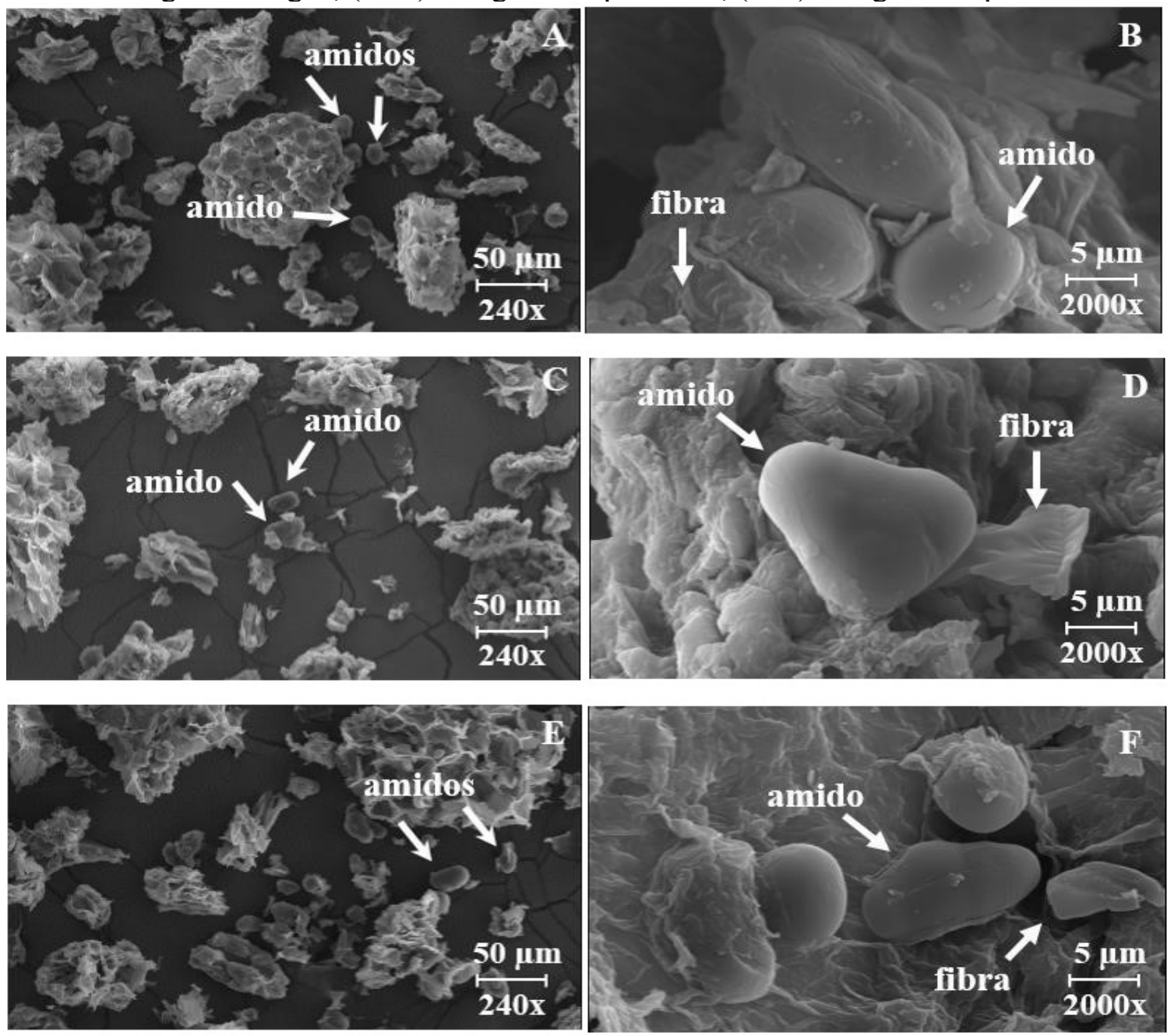


\subsubsection{Calorimetria diferencial de varredura (DSC)}

Os termogramas obtidos por DSC das suspensões de 10\% do resíduo de urucum e das farinhas permitiram visualizar os picos endotérmicos referentes ao processo de gelatinização e obter os valores das temperaturas correspondentes ao intervalo de gelatinização: temperatura inicial $\left(\mathrm{T}_{\mathrm{i}}\right)$, temperatura de pico $\left(\mathrm{T}_{\mathrm{p}}\right)$, temperatura final $\left(\mathrm{T}_{\mathrm{f}}\right)$, assim como obter o intervalo $\left(\mathrm{T}_{\text {gel }}\right)$ e a entalpia de gelatinização $\left(\Delta \mathrm{H}_{\text {gel }}\right)$, listados na Tabela 2.4. A Figura 2.8 apresenta o termograma de DSC de amostras de resíduo e farinhas WS, AS e KS.

$\mathrm{O}$ resíduo de urucum apresentou valores de $\mathrm{Ti}$ e $\mathrm{Tp}$ semelhantes aos obtidos para a farinha obtida por método de moagem em água ( $\mathrm{pH}$ neutro), porém estes valores foram maiores do que os obtidos para ass farinhas extraídas pelos metodos por moagem em $\mathrm{pH}$ ácido e moagem em $\mathrm{pH}$ alcalino. O menor teor de amido da farinha obtida por moagem em água, como mostrado na composição química, deve ter influenciado no maior valor da Ti e Tp quando comparado com as farinhas obtidas pelos métodos ácido e alcalino. Como a temperatura de gelatinização pode ser influenciada pela composição do grânulo de amido (amilose/amilopectina), a forma e o tamanho do grânulo de amido, estrutura molecular (comprimento das cadeias, regiões amorfas e cristalinas) e a presença de outros componentes como lipídeos, proteínas e fibras (GUNARATNE; HOOVER, 2002; NODA et al., 1996; SINGH; KAUR; SINGH, 2004; SINGH; SINGH, 2001; YUAN; THOMPSON; BOYER, 1993)

observa-se diferenças no intervalo de gelatinização dos materiais obtidos e do resíduo de urucum. Assim, o intervalo de gelatinização $\left(\mathrm{T}_{\text {gel }}\right)$ foi maior para o resíduo quando comparado com as farinhas, isto pode ser justificado pelo maior tamanho de partícula e presença de maiores aglomerados do resíduo de urucum (Figura 2.4), no qual os grânulos de amido estão aprisionados formando estruturas compactas, com foi verificado por MEV (Figura 2.5) (ROCHA; DEMIATE; FRANCO, 2008).

Também foi observada diferenças nos valores de entalpia de gelatinização $(\Delta \mathrm{H}$ gel $)$ das farinhas em função dos métodos de isolamento utilizados neste estudo. A entalpia de gelatinização $\left(\Delta \mathrm{H}_{\text {gel }}\right)$ foi maior para a farinha obtida pelo método alcalino devido ao maior tamanho de partícula deste material, quando comparado com as farinhas obtidas pelo método de moagem em água e em pH ácido, como pode ser verificado na Figura 2.4, sendo então, necessária maior quantidade de energia para clivar a estrutura dos grânulos de amido, apesar do menor teor de amilopectina desta farinha (teor de amilose 27\%) (AGAMA-ACEVEDO et al., 2014; CORAL et al., 2009; PELISSARI et al., 2012). Como o tamanho médio departícula dos amidos isolados 
por moagem em água e em meio ácido foram quase semelhantes, os valores de entalpia de gelatinização $\left(\Delta \mathrm{H}_{\text {gel }}\right)$ destes amidos não apresentaram diferença estatisticamente significativa segundo o teste de Tukey $(\mathrm{p}<0,05)$. A entalpia de gelatinização dos amidos de urucum produzidos neste trabalho $(6,9 \mathrm{a} 11 \mathrm{~J} / \mathrm{g})$ foi maior do que os amidos isolados a partir do mesocarpo do babaçu $(2,61 \mathrm{~J} / \mathrm{g})$, e menor ao relatado para o amido de castanha portuguesa $(16,3 \mathrm{~J} / \mathrm{g})$ (MANIGLIA; TAPIA-BLÁCIDO, 2016; NOR NADIHA et al., 2010; XIE et al., 2008).

Tabela 2.4 - Valores de temperatura e entalpia do intervalo de gelatinização dos amidos presentes no resíduo da extração de corante de urucum e nas farinhas obtidas por diferentes métodos de isolamento

\begin{tabular}{|c|c|c|c|c|c|}
\hline Amostras & $T_{i}\left({ }^{\circ} \mathrm{C}\right)$ & $T_{p}\left({ }^{\circ} \mathrm{C}\right)$ & $\mathbf{T}_{\mathrm{f}}\left({ }^{\circ} \mathrm{C}\right)$ & $\mathrm{T}_{\text {gel }}\left({ }^{\circ} \mathrm{C}\right)$ & $\Delta H_{\text {gel }}(\mathrm{J} / \mathrm{g})$ \\
\hline $\begin{array}{l}\text { Resíduo de } \\
\text { urucum }\end{array}$ & 63,42 & 70,48 & 78,58 & 14,13 & 3,19 \\
\hline $\begin{array}{c}\text { Farinha } \\
\text { (WS) }\end{array}$ & $64,00 \pm 0,07^{a}$ & $69,04 \pm 0,17^{\mathrm{a}}$ & $80,40 \pm 1,24^{\mathrm{a}}$ & 10,08 & $6,92 \pm 1,01^{b}$ \\
\hline $\begin{array}{c}\text { Farinha } \\
\text { (AS) }\end{array}$ & $60,92 \pm 0,22^{b}$ & $67,17 \pm 0,35^{\mathrm{b}}$ & $78,12 \pm 1,89^{a}$ & 12,3 & $7,80 \pm 0,66^{\mathrm{b}}$ \\
\hline $\begin{array}{c}\text { Farinha } \\
\text { (KS) }\end{array}$ & $61,09 \pm 0,04^{b}$ & $67,06 \pm 0,11^{\mathrm{b}}$ & $81,48 \pm 0,64^{\mathrm{a}}$ & 11,8 & $10,98 \pm 0,13^{a}$ \\
\hline
\end{tabular}

$\mathrm{T}_{\mathrm{i}}$ : temperatura inicial de gelatinização; $\mathrm{T}_{\mathrm{p}}$ : temperatura pico de gelatinização; $\mathrm{T}_{\mathrm{f}}$ :temperatura final de gelatinização; Tgel $=2 *(\mathrm{Tp}-\mathrm{To})$ : intervalo de gelatinização; $\Delta \mathrm{H}_{\text {gel }}$ : entalpia de gelatinização por grama de amido em base seca;

$\mathrm{a}, \mathrm{b}, \mathrm{c}$ : letras minúsculas diferentes na mesma coluna indicam que há diferença estatística significativa entre os métodos de extração (Tukey, $\mathrm{p}<0,05$ ).

(WS): moagem em água, (AS): moagem em pH ácido, (KS): moagem em pH alcalino.

Figura 2.8 - Termograma de DSC de resíduo e farinhas WS, AS e KS

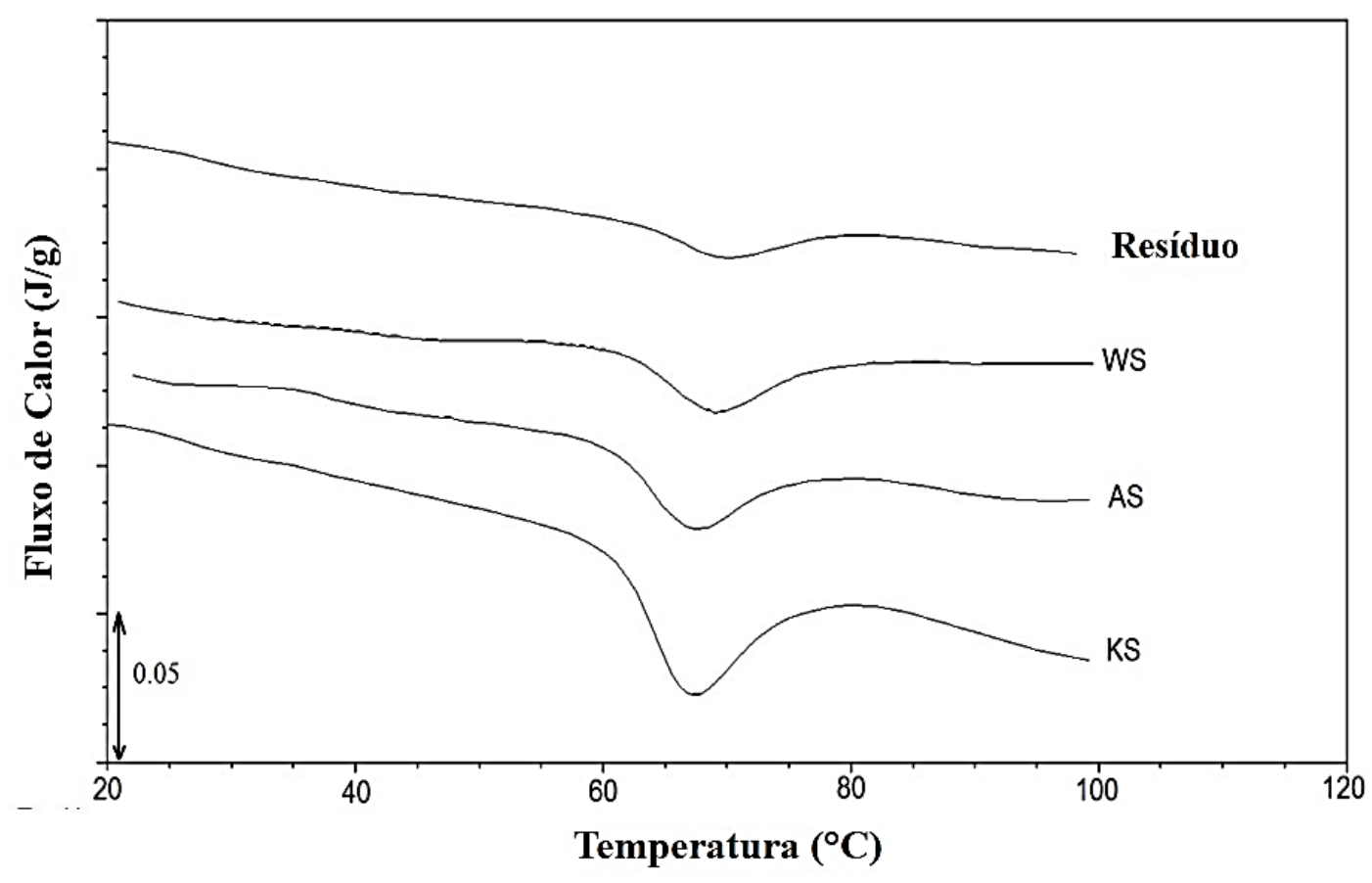




\subsubsection{Difração de raios-X}

Os difratogramas de raio $\mathrm{X}$ de resíduo de urucum, farinhas isoladas pelos métodos de moagem em água, moagem em $\mathrm{pH}$ ácido e moagem em $\mathrm{pH}$ alcalino e os correspondentes farelos estão apresentados na Figura 2.9. O resíduo de urucum e as farinhas obtidas pelos métodos de moagem em água, em $\mathrm{pH}$ ácido e em $\mathrm{pH}$ alcalino exibiram picos em $15^{\circ}, 17^{\circ}, 20^{\circ}, 22^{\circ}$ e $23^{\circ}$. A farinha obtida por moagem em $\mathrm{pH}$ ácido apresentou pico em $6^{\circ}$, típico de amido tipo A comum em cereais (KARIM; NORZIAH; SEOW, 2000) e apenas, o resíduo de urucum e a farinha extraída por moagem em água exibiram pico em $27^{\circ}$, típicos de amido tipo $\mathrm{B}$, comum em tubérculos (HOOVER, 2001; SHUJUN; JINGLIN; WENYUAN, 2005). Também foi observado um pico em $37^{\circ}$, o qual pode estar relacionado à celulose, pois foi mais evidente no resíduo de urucum e no farelo resultante da extração por moagem em água, que contem maior teor de fibras. O pico próximo a $20^{\circ}$ observado nas farinhas isoladas pelos três métodos é típico da presença de complexos amilose-lipídeos (CHEETHAM; TAO, 1998). Os picos em $17^{\circ}, 22^{\circ}$ e $35^{\circ}$ são característicos da celulose (NISHIYAMA; LANGAN; CHANZY, 2002; PARK et al., 2010). Estes picos apareceram nos difratogramas dos farelos devido à sua composição rica em fibras (Tabela 2.1 e Figura 2.7). As diferenças de intensidade dos picos, refletem as alterações na estrutura de cada uma das farinhas obtidas, que podem estar em função ao tipo de método de isolamento utilizado.

A amilopectina e celulose são as principais responsáveis pela cristalinidade das farinhas produzidas neste trabalho. A farinha isolada pelo método em $\mathrm{pH}$ ácido teve maior índice de cristalinidade (63,79\%) quando comparado às farinhas obtidas por moagem em água $(58,26 \%)$ e moagem em pH alcalino (54,12\%). Quanto aos farelos, o índice de cristalinidade do farelo obtido através do método ácido foi $45,79 \%$, valor próximo ao índice de cristalinidade do farelo obtido pelo método em água (44,64\%), enquanto o farelo obtido por moagem em $\mathrm{pH}$ alcalino teve menor índice de cristalinidade $(36,65 \%)$. O resíduo de urucum teve menor índice de cristalinidade $(11,48 \%)$ do que os materiais isolados. Índices de cristalinidade baixo, podem indicar a presença de componentes amorfos como a celulose amorfa, lignina e hemicelulose (REDDY et al., 2010). 
Figura 2.9 - Difratograma de raios-X (A) resíduo da extração de corante de urucum, farinhas isoladas por moagem em água (WS), moagem em pH ácido (AS), moagem em meio alcalino (KS) e (B) respectivos farelos
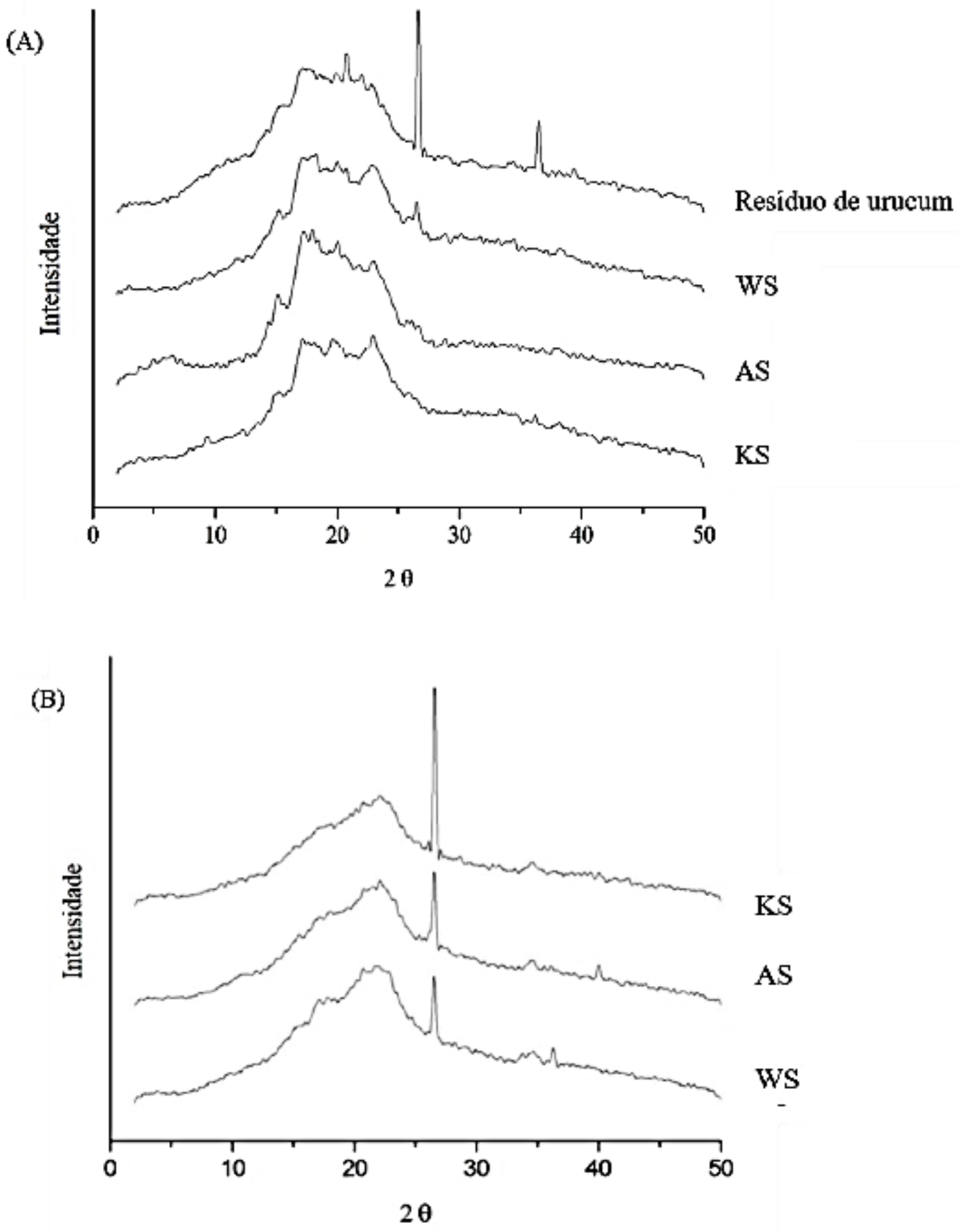


\subsubsection{Espectroscopia de absorção na região do infravermelho (FTIR)}

A Figura 2.10 mostra os espectros de FTIR de resíduo de urucum, farinhas obtidas pelos métodos de moagem em água, moagem em $\mathrm{pH}$ ácido, moagem em $\mathrm{pH}$ alcalino e os correspondentes farelos. Os espectros de FTIR mostraram comportamento semelhante para os materiais estudados, com a presença das mesmas bandas típicas de grupos funcionais.

A região IR de 3700 - $3000 \mathrm{~cm}^{-1}$ são atribuídos à presença de grupos hidroxilas ou às vibrações de estiramento das ligações $\mathrm{O}-\mathrm{H}$, pela presença de interações intra e intermoleculares das ligações de hidrogênio (ABIDI; CABRALES; HAIGLER, 2014; OH et al., 2005). O resíduo de urucum, farinhas e farelos obtidos pelos métodos apresentaram pico próximo a $3328 \mathrm{~cm}^{-1}$.

$\mathrm{Na}$ região IR entre $3000-2800 \mathrm{~cm}^{-1}$ tem-se duas bandas, com picos em $2927 \mathrm{~cm}^{-1} \mathrm{e}$ $2850 \mathrm{~cm}^{-1}$ associados aos estiramentos simétricos e assimétricos de $\mathrm{CH}_{2}$, respectivamente (ABIDI; CABRALES; HEQUET, 2010; NELSON; MARES, 1965) presentes em todos os materiais estudados. Segundo (ABIDI; CABRALES; HAIGLER, 2014), o pico $2850 \mathrm{~cm}^{-1}$ está relacionado a presença de celulose e proteína.

A região IR entre 1800 - $1500 \mathrm{~cm}^{-1}$, observa-se três bandas de vibração em $1712 \mathrm{~cm}^{-1}$, $1648 \mathrm{~cm}^{-1}, 1568 \mathrm{~cm}^{-1}$. O pico em $1712 \mathrm{~cm}^{-1}$ é atribuído ao estiramento de grupos carbonila presentes em hemicelulose ou lipídeos. A vibração em $1648 \mathrm{~cm}^{-1}$ é atribuída ao estiramento da ligação $\mathrm{C}=\mathrm{O}$ (amida I) em proteínas (FABIAN; SCHULTZ, 2000).

O pico em $1568 \mathrm{~cm}^{-1}$, pode ser atribuído às vibrações de grupo amida II devido à banda de acoplamento da deformação angular de $\mathrm{NH}_{2}, \mathrm{H}_{2} \mathrm{O}$ e ao estiramento de $\mathrm{C}-\mathrm{N}$ (KONG; YU, 2007; ROLERE et al., 2015).

Na região de 1500 a $1200 \mathrm{~cm}^{-1}$ há um acoplamento de bandas, podendo-se observar três picos em todos as farinhas e os respectivos farelos, com exceção do resíduo de urucum, sendo eles 1426,1350 e $1245 \mathrm{~cm}^{-1}$. As vibrações em 1426 e $1350 \mathrm{~cm}^{-1}$ são atribuídas as deformações no plano dos grupos $\mathrm{O}-\mathrm{H}$ e estiramento de $\mathrm{C}-\mathrm{H}$, respectivamente, atribuídas a estruturas cristalinas da celulose ou amido (LENZ, 1994; NELSON; MARES, 1965).

Em $1245 \mathrm{~cm}^{-1}$, a vibração corresponde ao estiramento de $\mathrm{C}=\mathrm{O}$ ou deformação do grupo $\mathrm{NH}_{2}$ que ocorrem em aminoácidos e pectinas (ABIDI; CABRALES; HAIGLER, 2014; NELSON; MARES, 1965).

A região de 1200 até $750 \mathrm{~cm}^{-1}$, observa-se picos em 1160, 1078, 1013, 960, 862 e 763 $\mathrm{cm}^{-1}$. O pico em $1160 \mathrm{~cm}^{-1}$ foi associado às vibrações de estiramento de C-O-C em materiais não celulósicos (CORREIA; NUNES; BEIRÃO-DA-COSTA, 2013). O pico em $1078 \mathrm{~cm}^{-1}$ 
corresponde ao estiramento de grupos C-O (ABIDI; CABRALES; HEQUET, 2010), típico de carboidratos. A vibração em $1009 \mathrm{~cm}^{-1}$ é relacionado ao estiramento das ligações C-C (ROLERE et al., 2015), C-O (ABIDI; CABRALES; HAIGLER, 2014) e C-H (LI et al., 2015). Em $960 \mathrm{~cm}^{-1}$, há vibrações geradas por estiramento de C-C, em $862 \mathrm{~cm}^{-1}$ há vibrações fora do plano de flexão de $\mathrm{C}=\mathrm{C}-\mathrm{H}$ e deformação angular de $-\mathrm{CH}_{2}-\mathrm{em} 763 \mathrm{~cm}^{-1}$. 
Figura 2.10 - FTIR (A) do resíduo da extração de corante de urucum, farinhas isoladas por moagem em água (WS), moagem em pH ácido (AS), moagem em pH alcalino (KS) e (B) respectivos farelos
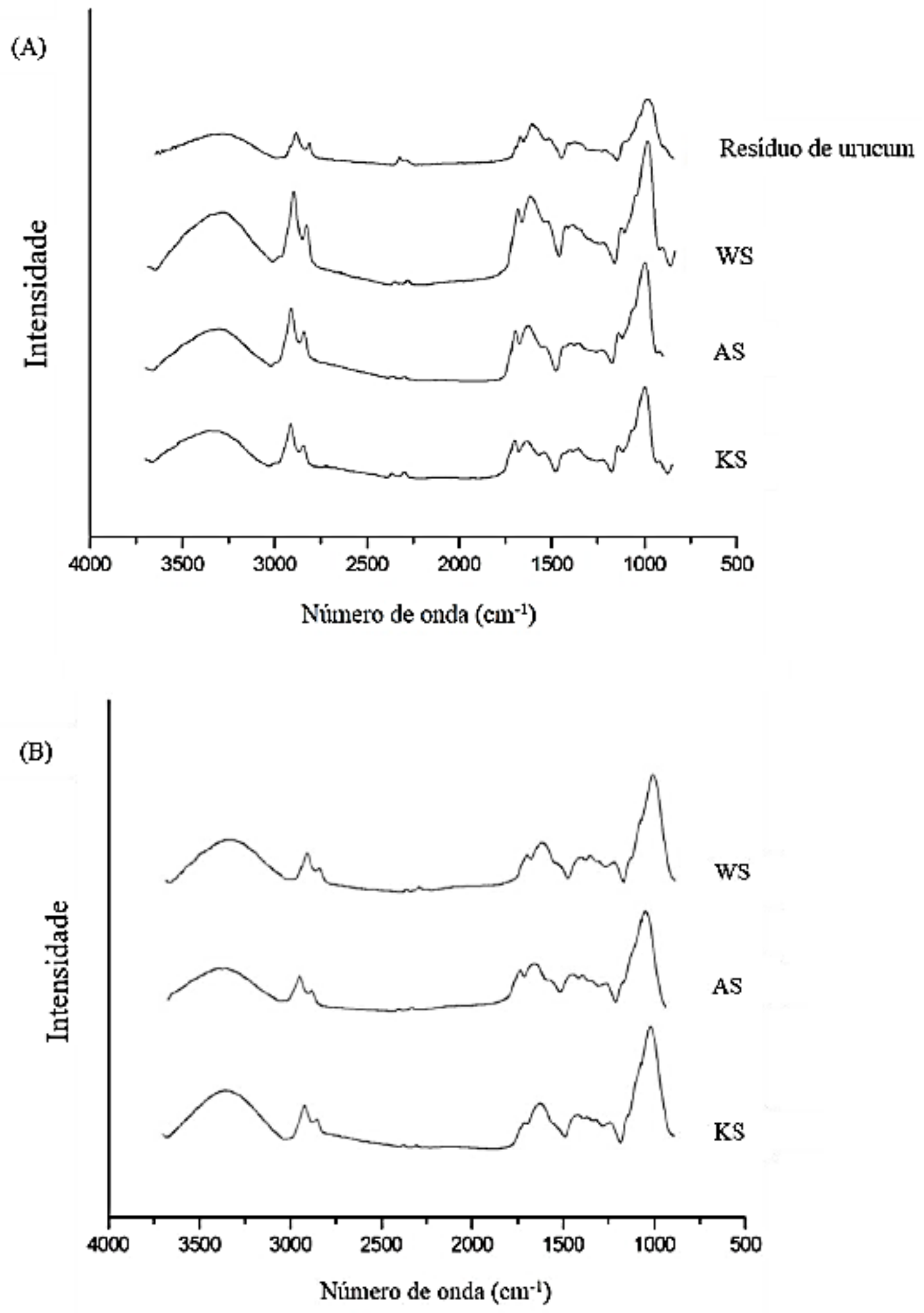


\subsection{Conclusão}

O resíduo da extração de corante de urucum apresentou importante teor de amido, fibras, proteínas, e lipídeos, além de compostos fenólicos e carotenoides, que não foram totalmente extraídos durante o processo industrial. A presença destes compostos dificultou a liberação dos grânulos de amido durante os processos de isolamento empregados neste estudo, obtendo-se baixos rendimentos no processo e um material que não pode ser considerado como amido devido ao baixo grau de pureza, portanto foi considerado como farinha. Demonstrou-se que os grânulos de amido presentes no resíduo de urucum são difíceis de serem liberados nos processos de isolamento testados por estarem fortemente retidos em estruturas fibrosas, formando complexos com proteínas, lipídeos e com os compostos ativos, carotenoides e compostos fenólicos. Assim, os métodos de isolamento utilizando diferentes pHs (neutro, ácido e alcalino) não foram eficientes na remoção dos compostos fenólicos e dos carotenoides, o que também causou menor liberação dos grânulos de amido. Portanto, as farinhas obtidas apresentaram coloração avermelhada devido à presença de bixina, com diferença na intensidade dos tons em função ao método de isolamento utilizado. O tipo de método utilizado para o isolamento de amido influenciou na composição química, cristalinidade, distribuição do tamanho de partículas e propriedades funcionais das farinhas obtidas. O método em $\mathrm{pH}$ alcalino foi o mais eficiente na remoção de proteínas e lipídeos permitindo obter farinha com maior teor de amilose, mas causou perda de compostos fenólicos e carotenoides. Já o método em pH ácido foi o mais eficiente na remoção das fibras e permitiu obter farinha com maior atividade antioxidante devido ao maior teor de compostos fenólicos e carotenoides. A farinha isolada pelo método em pH alcalino apresentou maiores aglomerados de grânulos de amido, o qual influenciou nas suas propriedades térmicas, pois precisou de mais calor para gelatinizar (maior $\Delta \mathrm{H}$ gel) do que as farinhas obtidas por moagem em água e em pH ácido, que apresentaram grânulos mais soltos e distribuição bimodal. As farinhas obtidas a partir do resíduo da extração de corante de urucum podem ser aplicadas como ingrediente alimentar e em produção de filmes biodegradáveis por seu alto teor de amido e presença de compostos bioativos. 


\subsection{Referências Bibliográficas}

ABIDI, N.; CABRALES, L.; HAIGLER, C. H. Changes in the cell wall and cellulose content of developing cotton fibers investigated by FTIR spectroscopy. Carbohydrate Polymers, v. 100, p. 9-16, jan. 2014.

ABIDI, N.; CABRALES, L.; HEQUET, E. Fourier transform infrared spectroscopic approach to the study of the secondary cell wall development in cotton fiber. Cellulose, v. 17, n. 2, p. 309-320, 20 abr. 2010.

AGAMA-ACEVEDO, E. et al. Starch isolation and partial characterization of commercial cooking and dessert banana cultivars growing in Mexico. Starch - Stärke, v. 66, n. 3-4, p. 337-344, mar. 2014.

ANGELO, P. M.; JORGE, N. Phenolic compounds in foods - a brief review. Rev. Inst. Adolfo Lutz (Impr.), v. 66, n. 1, p. 1-9, 2007.

AOAC-920.151, A. OF O. A. C. Official Methods of Analysis of AOAC International. 16. ed. Washington: AOAC International, 1997.

AOAC-923.03, A. OF O. A. C. Official Methods of Analysis of AOAC International. 16. ed. Washington: AOAC International, 1997.

AOAC-926.86, A. OF O. A. C. Official Methods of Analysis of AOAC International. 18. ed. Maryland: AOAC International, 2005.

BILIADERIS, C. G. The structure and interactions of starch with food constituents. Canadian journal of physiology and pharmacology, v. 69, n. 1, p. 60-78, jan. 1991.

BLIGH, E. G.; DYER, W. J. A rapid method of total lipid extraction and purification. Canadian journal of biochemistry and physiology, v. 37, n. 8, p. 911-7, ago. 1959.

BOBBIO, P. A.; BOBBIO, F. O. Introdução à Química de Alimentos. 2. ed. São Paulo: Valera, 1992.

BRETT, C.; WALDRON, K. Physiology and Biochemistry of Plant Cell Walls. Dordrecht: Springer Netherlands, 1990.

BRITO, J. G. DE et al. Armazenamento de grãos residuais de urucum sob atmosfera controlada. Rev. bras. eng. agríc. ambient., v. 19, 2015.

CARVALHO, P. R. N.; CARVALHO, C. R. L.; MANTOVANI, D. M. B. Estudo da composição de sementes, cachopas, folhas e galhos do urucuzeiro. Campinas: 1991

CHEETHAM, N. W. ;; TAO, L. Variation in crystalline type with amylose content in maize starch granules: an X-ray powder diffraction study. Carbohydrate Polymers, v. 36, n. 4, p. 277-284, ago. 1998.

CORAL, D. F. et al. Determination of the gelatinization temperature of starch presented in maize flours. Journal of Physics: Conference Series, v. 167, p. 12057, 1 maio 2009.

CORREIA, P. R.; BEIRÃO-DA-COSTA, M. L. Chestnut and acorn starch properties affected by isolation methods. Starch - Stärke, v. 62, n. 8, p. 421-428, 22 jun. 2010.

CORREIA, P. R.; BEIRÃO-DA-COSTA, M. L. Starch isolation from chestnut and acorn flours 
through alkaline and enzymatic methods. Food and Bioproducts Processing, v. 90, n. 2, p. 309-316, 2012.

CORREIA, P. R.; NUNES, M. C.; BEIRÃO-DA-COSTA, M. L. The effect of starch isolation method on physical and functional properties of Portuguese nut starches. II. Q. rotundifolia Lam. and Q. suber Lam. acorns starches. Food Hydrocolloids, v. 30, n. 1, p. 448-455, 2013.

ESTRADA-LEÓN, R. J. et al. The effect of isolation method on properties of parota (Enterolobium cyclocarpum) starch. Food Hydrocolloids, v. 57, p. 1-9, 2016.

FABIAN, H.; SCHULTZ, C. P. Fourier Transform Infrared Spectroscopy in Peptide and Protein Analysis. In: Encyclopedia of Analytical Chemistry. Chichester, UK: John Wiley \& Sons, Ltd, 2000.

GONNET, J.-F. Colour effects of co-pigmentation of anthocyanin revisited-3.A further description using CIELAB differences and assessmentof matched colours using the CMC model. Food Chemistry, p. 473-485, 2001.

GROSS, J. Carotenoids. In: GROSS, J. (Ed.). . Pigments in vegetables, Chlorophylls and Carotenoids. London: Academic Press, 1991. p. 75-335.

GUIMARÃES, C. P.; LANFER-MARQUEZ, U. M. Estimativa do teor de fenilalanina em sopas desidratadas instantâneas: importância do nitrogênio de origem não-protéica. Revista Brasileira de Ciências Farmacêuticas, v. 41, n. 3, set. 2005.

GUNARATNE, A.; HOOVER, R. Effect of heat-moisture tratment on the struc-ture and physicochemical properties of tuber and root starches. CarbohydratesPolymers., v. 49, p. 425-437, 2002.

HERNÁNDEZ-MEDINA, M. et al. Caracterización fisicoquímica de almidones de tubérculos cultivados en Yucatán, México. Ciência e Tecnologia de Alimentos, v. 28, n. 3, p. 718-726, set. 2008.

HILLIS, W. E.; SWAIN, T. The phenolic constituents ofPrunus domestica. II.-The analysis of tissues of the Victoria plum tree. Journal of the Science of Food and Agriculture, v. 10, n. 2, p. 135-144, fev. 1959.

HOOVER, R. Composition, molecular structure, and physicochemical properties of tuber and root starches: a review. Carbohydrate Polymers, v. 45, n. 3, p. 253-267, jul. 2001.

HUNTERLAB. Manual do equipamento Hunter Lab. Imagem do sólido de cores.

JULIANO, O. B. A simplified assay for milled-rice amylose. Cereal Science today, v. 16, p. 334-340, 1971.

KARIM, A. A.; NORZIAH, M.; SEOW, C. Methods for the study of starch retrogradation. Food Chemistry, v. 71, p. 9-36, 2000.

KONG, J.; YU, S. Fourier transform infrared spectroscopic analysis of protein secondary structures. Acta biochimica et biophysica Sinica, v. 39, n. 8, p. 549-59, ago. 2007.

LENZ, R. W. Cellulose, structure, accessibility and reactivity, by H. A. Krässig, Gordon and Breach Publishers, 5301 Tacony Street, Philadelphia, PA, 1993; xvi +376 pp. Price: $\$ 260.00$. Journal of Polymer Science Part A: Polymer Chemistry, v. 32, n. 12, p. 2401-2401, set. 1994. 
LI, W. et al. Characterization of cellulose from banana pseudo-stem by heterogeneous liquefaction. Carbohydrate Polymers, v. 132, p. 513-519, nov. 2015.

MANIGLIA, B. C.; TAPIA-BLÁCIDO, D. R. Isolation and characterization of starch from babassu mesocarp. Food Hydrocolloids, v. 55, p. 47-55, abr. 2016.

MARTÍNEZ, C.; CUEVAS, F. Evaluación de la calidad culinária y molinaria del arroz. In: Guia de Estudo. [s.l: s.n.]. p. 75.

MEDINA, J. A.; SALAS, J. C. Morphological Characterization of Native Starch Granule: Appearance, Shape, Size and its Distribution. Revista de Ingeniería, v. 27, p. 56-62, 2008.

MOORE, C. O. et al. Effect of the alkaline and acid treatments on the physicochemical properties of corn starch. In: WHISTLER, R. L. (Ed.). . Starch: Chemistry and technology. [s.l: s.n.]. p. 407-410.

MORTENSEN, A. Carotenoids and other pigments as natural colorants. Pure and Applied Chemistry, v. 78, n. 8, 1 jan. 2006.

NARA, S.; KOMIYA, T. Studies on the Relationship Between Water-satured State and Crystallinity by the Diffraction Method for Moistened Potato Starch. Starch - Stärke, v. 35, n. 12, p. 407-410, 1983.

NELSON, M. L.; MARES, T. Accessibility and Lateral Order Distribution of the Cellulose in the Developing Cotton Fiber1. Textile Research Journal, v. 35, n. 7, p. 592-603, 1 jul. 1965.

NISHIYAMA, Y.; LANGAN, P.; CHANZY, H. Crystal Structure and Hydrogen-Bonding System in Cellulose I $\beta$ from Synchrotron X-ray and Neutron Fiber Diffraction. Journal of the American Chemical Society, v. 124, n. 31, p. 9074-9082, ago. 2002.

NODA, T. et al. Physicochemical Properties of Starches from Purple and Orange Fleshed Sweet Potato Roots at Two Levels of Fertilizer. Starch - Starke, v. 48, n. 11-12, p. 395-399, 1996.

NOR NADIHA, M. Z. et al. Comparative susceptibilities of sago, potato and corn starches to alkali treatment. Food Chemistry, v. 121, n. 4, p. 1053-1059, ago. 2010.

$\mathrm{OH}, \mathrm{S}$. Y. et al. FTIR analysis of cellulose treated with sodium hydroxide and carbon dioxide. Carbohydrate Research, v. 340, n. 3, p. 417-428, fev. 2005.

PALACIOS-FONSECA, A. J. et al. Effect of the alkaline and acid treatments on the physicochemical properties of corn starch. CyTA - Journal of Food, v. 11, n. sup1, p. 67-74, maio 2013.

PARK, S. et al. Cellulose crystallinity index: measurement techniques and their impact on interpreting cellulase performance. Biotechnology for Biofuels, v. 3, n. 1, p. 10, 2010.

PEDROSA, J. P.; CIRNE, L. E. M. R.; MAGALHÃES NETO, J. M. Teores de bixina e proteína em sementes de urucum em função do tipo e do período de armazenagem. Revista Brasileira de Engenharia Agrícola e Ambiental., v. 1, n. 1, p. 121-123, 1999.

PELISSARI, F. M. et al. Isolation and characterization of the flour and starch of plantain bananas ( Musa paradisiaca ). Starch - Stärke, v. 64, n. 5, p. 382-391, maio 2012.

PIMENTEL, F. A.; STRINGHETA, P. C. Produção de corantes de urucum em pó, por meio de precipitação ácida, a partir de extratos obtidos em diferentes soluções extratoras. Revista Brasileira de Corantes Naturais, v. 3, p. 53-57, 1999. 
PROSKY, L.; LEE, S. C. Dietary Fiber and its Applications: Definitions, Analytical Methods and their Applicattions. Special Publications of the Royal Society of Chemistry, v. 181, p. 303-310, 1996.

REDDY, K. et al. Structural characterization of coconut tree leaf sheath fiber reinforcement. Journal of Forestry Research, v. 21, n. 1, p. 53-58, 10 mar. 2010.

RIBEIRO, E. P.; SERAVALLI, E. A. G. Química de alimentos. São Paulo: Edgard Blücler, 2004.

ROCHA, T. S.; DEMIATE, I. M.; FRANCO, C. M. L. Características estruturais e físicoquímicas de amidos de mandioquinha-salsa (Arracacia xanthorrhiza). Ciência e Tecnologia de Alimentos, v. 28, n. 3, p. 620-628, set. 2008.

ROLERE, S. et al. Investigating natural rubber composition with Fourier Transform Infrared (FT-IR) spectroscopy: A rapid and non-destructive method to determine both protein and lipid contents simultaneously. Polymer Testing, v. 43, p. 83-93, maio 2015.

RONDÁN-SANABRIA, G.; FINARDI-FILHO, F. Physical-chemical and functional properties of maca root starch (Lepidium meyenii Walpers). Food Chemistry, v. 114, n. 2, p. 492-498, 15 maio 2009.

ROONEY, L.; SUHENDRO, E. Perspectives on nixtamalization (alkaline cooking) of maize for tortillas and snacks. Cereal Foods World, v. 44, n. 7, p. 466-470, 1999.

RUFINO, M. DO S. M. et al. Metodologia Científica: Determinação da Atividade Antioxidante Total em Frutas pela Captura do Radical Livre ABTS +. . 2007.

SHUJUN, W.; JINGLIN, Y.; WENYUAN, G. Use of X-Ray Diffractometry (XRD) for Identification of Fritillaria According to Geographical Origin. American Journal of Biochemistry and Biotechnology, v. 1, n. 4, p. 199-203, 1 dez. 2005.

SINGH, J.; KAUR, L.; SINGH, N. Effect of Acetylation on Some Properties of Corn and Potato Starches. Starch, v. 56, n. 12, p. 586-601, dez. 2004.

SINGH, J.; SINGH, N. Studies on the morphological, thermal and rheological properties of starch separated from some Indian potato cultivars. Food Chemistry, v. 75, n. 1, p. 67-77, out. 2001.

SUN, J. X. et al. Isolation and characterization of cellulose from sugarcane bagasse. Polymer Degradation and Stability, v. 84, n. 2, p. 331-339, maio 2004.

TORRUCO-UCO, J.; BETANCUR-ANCONA, D. Physicochemical and functional properties of makal (Xanthosoma yucatanensis) starch. Food Chemistry, v. 101, n. 4, p. 1319-1326, 2007.

UTIYAMA, C. E.; MIYADA, V. S.; FIGUEIREDO, A. N. Digestibilidade de nutrientes do resíduo de semente processadas de urucum (Bixa orellana) para suínos. Reunião anual da sociedade brasileira de zootecnia. Anais: Sociedade Brasileira de Zootecnia. Anais...Recife: 2002

VALÉRIO, M. A. et al. Annatto seed residue (Bixa orellana L.): nutritional quality. Food Science and Technology (Campinas), v. 35, n. 2, p. 326-330, jun. 2015.

VAN SOEST, P. J. Nutritional Ecology of the Ruminant. 2. ed. Ithaca, New York: Cornell University Press, 1996. 
XIE, X. (SHERRY) et al. Isolation and characterization of wheat bran starch. Food Research International, v. 41, n. 9, p. 882-887, nov. 2008.

YUAN, R. C.; THOMPSON, D. B.; BOYER, C. D. Fine structure of amylopectin in relation to gelatinization and retrogradation behavior of maize starches from three wx-containing genotypes in two inbred lines. Cereal Chemistry., v. 70, p. 81-89., 1993. 
Capitulo 3. FILMES BIODEGRADÁVEIS A BASE DE FARINHA OBTIDA DO RESÍDUO DE URUCUM 


\section{Apresentação}

Este capítulo aborda a produção e caracterização de filmes de farinha de urucum obtida por três diferentes métodos: moagem em água (WS), moagem em pH ácido (AS) e moagem em $\mathrm{pH}$ alcalino (KS) a partir do resíduo de urucum. Os filmes foram elaborados em diferentes $\mathrm{pH}$ $(5,7,9)$ e tempos de aquecimento $(1 \mathrm{~h}, 2 \mathrm{~h}, 3 \mathrm{~h}, 4 \mathrm{~h})$. Para estudar o efeito destas variáveis: tipo de farinha, $\mathrm{pH}$ e tempo de aquecimento sobre as propriedades mecânicas e propriedades funcionais (umidade, solubilidade e permeabilidade ao vapor de água) foi utilizado um planejamento fatorial completo $3 \times 3 \times 4$. A partir dos resultados obtidos neste planejamento foi escolhida a melhor condição em $\mathrm{pH}$ e tempo de aquecimento para produzir os filmes de farinha de urucum WS, ASe KS. Estes filmes foram caracterizados e comparados em base a suas propriedades mecânicas e funcionais. Dentre os filmes de farinha WS, AS e KS, verificou-se que os filmes de farinha KS foram menos hidrofílicos, mais permeáveis ao vapor de água, menos solúveis, menos úmidos e mais resistentes mecanicamente do que os filmes de farinha WS e AS.

\subsection{Materiais e Métodos}

\subsubsection{Materiais}

O resíduo da extração de corante de urucum (Bixa Orellana) foi fornecido pela empresa de corantes "Firace" (São Paulo, Brasil). A farinha de urucum foi isolada a partir deste resíduo por moagem em água (WS), moagem em pH ácido (AS) e moagem em pH alcalino (KS), como descrito no Capítulo 2, item 2.2.2.

Os reagentes $\mathrm{HCl}$ e $\mathrm{NaOH}$ usados para ajustar o $\mathrm{pH}$ foram adquiridos da LS Chemicals (São Paulo, Brasil) e da Dinâmica Química Contemporânea (Diadema-SP, Brasil), respectivamente. $\mathrm{O}$ glicerol utilizado como plastificante foi adquirido da Sigma-Aldrich.

\subsubsection{Elaboração dos filmes de farinha de urucum}

Os filmes de farinha de urucum WS, AS e KS foram elaborados segundo método casting (GONTARD; GUILBERT; CUQ, 1992), como mostrado na Figura 3.1. Inicialmente, foi preparada uma suspensão $5 \%(\mathrm{~m} / \mathrm{m})$ de farinha de urucum em água deionizada, a qual foi 
homogeneizada por 3 minutos a $10000 \mathrm{rpm}$ em Ultra-Turrax (TE-102-Turratec, Tecnal). Após homogeneização, foi feito o ajuste de pH em 5, 7 e 9, utilizando solução de $\mathrm{HCl} 1 \mathrm{M}$ ou solução $\mathrm{NaOH} 1 \mathrm{M}$. Em seguida, a suspensão foi aquecida a $85^{\circ} \mathrm{C}$ sob agitação magnética (IKA ${ }^{\circledR} \mathrm{C}$ MAG HS7- Marconi) por tempos de aquecimentos de 1h, 2h, 3h e 4h, aplicando-se ciclos de homogeneização (3 min a $10000 \mathrm{rpm}$ ) a cada 1 h em Ultra-Turrax. Faltando aproximadamente 15 min para o término do tempo de aquecimento das soluções foi adicionado o plastificante (glicerol: $25 \mathrm{~g} / 100 \mathrm{~g}$ de farinha). Posteriormente, a solução foi vertida em placas de acrílico (gramatura de $0,15 \mathrm{~g} / \mathrm{m}^{2}$ ), e em seguida foi realizada a secagem durante $12 \mathrm{~h}$ a $35^{\circ} \mathrm{C}$ e $45 \% \mathrm{UR}$ em uma estufa (BOD modelo SL 200-364, marca SOLAB, Piracicaba, Brasil). Os filmes secos foram cortados em moldes e acondicionados em dessecadores a 58\% UR (solução saturada de $\mathrm{NaBr}$ ) a temperatura ambiente.

Figura 3.1- Fluxograma de elaboração dos filmes de urucum por método casting

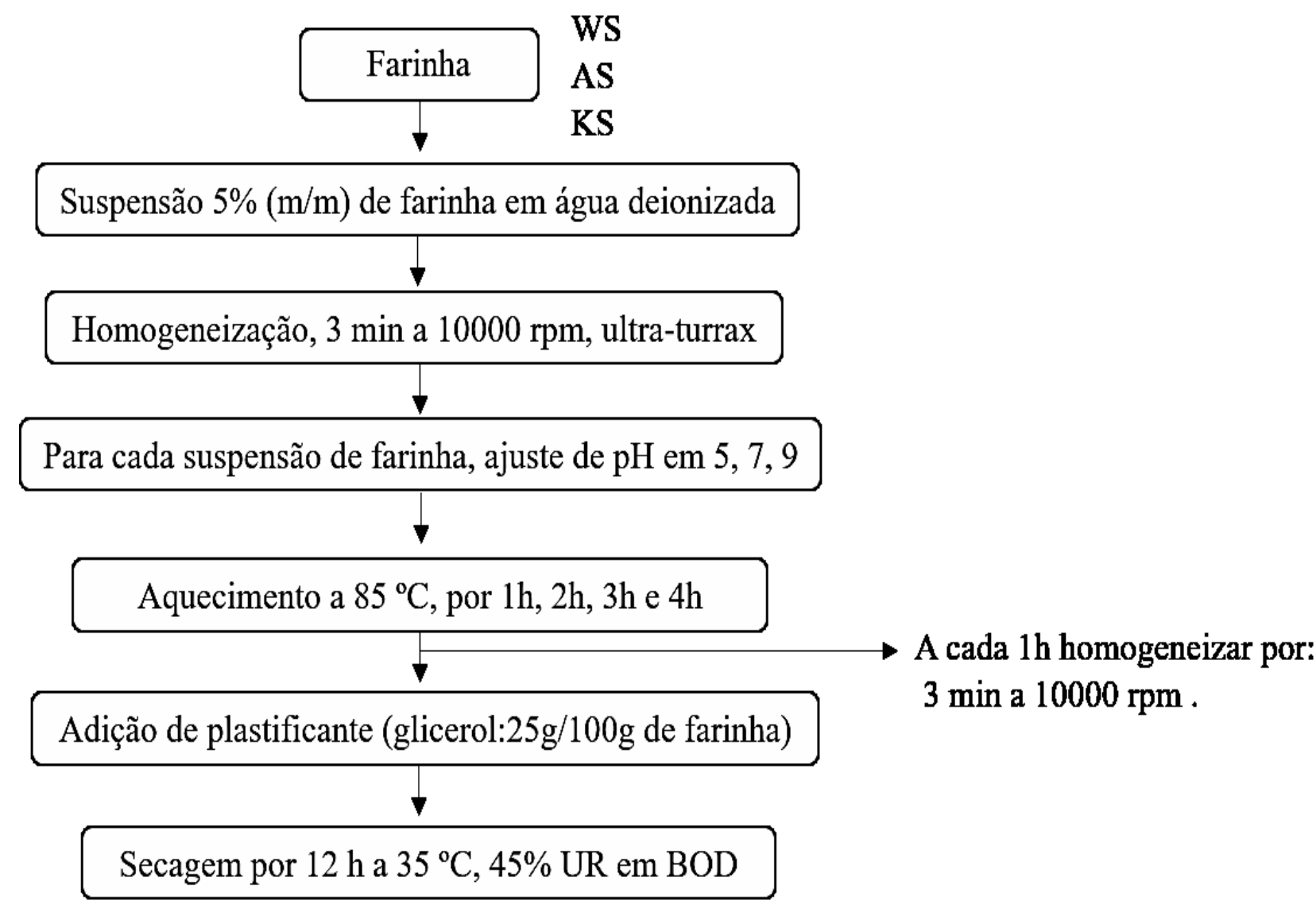




\subsubsection{Caracterização dos filmes de farinha de urucum}

\subsubsection{Espessura dos filmes}

A espessura dos filmes pré-condicionados $\left(58 \% \mathrm{UR}, 25^{\circ} \mathrm{C}\right)$ foi avaliada com auxílio de um micrômetro digital Zaas- Precision de ponta plana (com resolução de $1 \mu \mathrm{m}$ ). Foram realizadas 10 medições em posições aleatórias para determinação da espessura média.

\subsubsection{Propriedades mecânicas dos filmes}

Os testes mecânicos de tração foram realizados em um Texturômetro TA XT Plus (TA Instrument, Inglaterra) empregando-se o software do equipamento “Texture Expert" versão 1.22. As análises foram realizadas em quintuplicata. A tensão e a elongação na ruptura em teste de tração foram determinadas de acordo com a norma ASTM D882-09 (ASTM, 2002). Os filmes foram cortados em corpo de prova segundo a Figura 3.2 e submetidos à tração com velocidade de $1,0 \mathrm{~mm} / \mathrm{s}$, partindo-se de uma separação inicial de $80 \mathrm{~mm}$, até a ruptura do filme. A tensão na ruptura e a elongação na ruptura foram obtidas diretamente da curva de tensão em função da elongação, conhecidas as dimensões iniciais dos corpos de prova. O módulo de elasticidade, ou módulo de Young, foi obtido da tangente na região linear da curva.

Figura 3.2 - Esquema do corpo de prova para teste de tração

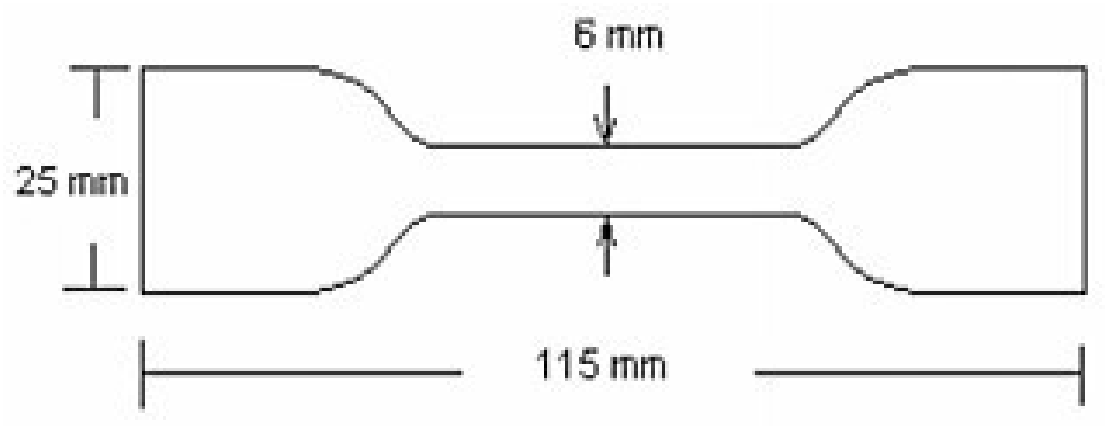




\subsubsection{Umidade}

A umidade dos filmes foi determinada segundo a técnica da ASTM D644-99 (ASTM, 1999). Aproximadamente $1 \mathrm{~g}$ de filme foi colocada em pesa-filtros e levadas à estufa (Quimis, Q314M292, Brasil) a $105^{\circ} \mathrm{C}$ por 24 horas. A umidade dos filmes foi calculada pela seguinte equação:

$$
\text { Umidade }(\%)=\left(1-\frac{m f}{m_{i}}\right) \times 100
$$

Sendo: mi: massa inicial dos filmes (g); mf: massa final dos filmes $(\mathrm{g})$.

\subsubsection{Solubilidade}

A solubilidade em água dos filmes foi calculada como a percentagem de matéria seca do filme solubilizado após imersão durante 24 horas em água a $25 \pm 2{ }^{\circ} \mathrm{C}$ (GONTARD; GUILBERT, 1992), como descrito por TAPIA-BLÁCIDO; SOBRAL; MENEGALLI (2011). Três discos de cada amostra de filme, com $2 \mathrm{~cm}$ de diâmetro, previamente pesados, foram imersos em $50 \mathrm{~mL}$ de água contendo azida sódica $(0,02 \% \mathrm{p} / \mathrm{v})$, e mantidos por 24 horas a 25 ${ }^{\circ} \mathrm{C}$, sob agitação em um shaker (Solab SL-223, Piracicaba, Brasil), após o qual, foi determinado o conteúdo de matéria seca não solubilizada. A matéria sólida insolúvel foi determinada segundo a técnica 971.09 da AOAC, (1995). A solubilidade foi calculada segundo a equação:

$$
\text { Solubilidade }(\%)=\left(1-\frac{m f}{m_{i}}\right) \times 100
$$

Sendo: mi: massa inicial dos filmes (g); mf: massa final dos filmes (g).

\subsubsection{Permeabilidade ao vapor de água (PVA)}

A permeabilidade ao vapor de água dos filmes foi determinada segundo o método padrão ASTM E96-95 modificado (ASTM, 1995). As determinações foram realizadas em triplicata. As amostras de filmes foram fixadas em suportes de alumínio com abertura circular de $34 \mathrm{~mm}$, correspondendo à área do filme exposta para a troca, vedada hermeticamente, e contendo sílica gel no seu interior ( $0 \%$ UR). Os suportes de alumínio foram colocados dentro de dessecadores contendo água destilada (100\% UR, $\mathrm{P}=3,167 \mathrm{KPa}$ à $\left.25{ }^{\circ} \mathrm{C} \pm 2{ }^{\circ} \mathrm{C}\right)$, com ambiente equilibrado durante 48 horas antes da análise (Figura 3.3). 
Figura 3.3 - Esquema do meio utilizado para determinar a permeabilidade ao vapor de água PVA

Suporte de aluminio

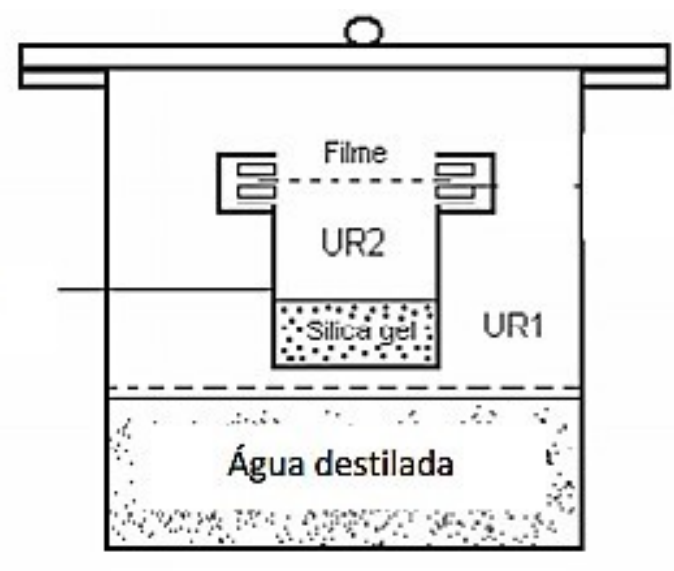

A massa do sistema (suporte + filme) foi determinada em balança semi-analítica (Sartorius-BL210S, Alemanha) em intervalos de 1 hora durante 7 horas. A taxa de permeabilidade ao vapor de água (PVA) foi calculada utilizando a equação:

$$
\mathrm{PVA}=\frac{w \delta}{t A \Delta_{P}} \quad\left(\mathrm{~g} \cdot \mathrm{m}^{-1} \cdot \mathrm{h}^{-1} \cdot \mathrm{KPa}^{-1}\right)
$$

Sendo: w/t: relação calculada por regressão linear dos pontos experimentais de ganho de massa $(\mathrm{g})$ da célula medida em função do tempo (h) para a zona de estado estacionário $\left(\mathrm{r}^{2}=\right.$ 0,98); A é a área de permeação do filme $\left(0,00196 \mathrm{~m}^{2}\right), \delta$ é a espessura média dos filmes (m) e $\Delta \mathrm{P}$ é a diferença entre a pressão parcial da atmosfera sobre a sílica gel e sobre a água pura $\left(3,168 \mathrm{kPa}\right.$, a $\left.25^{\circ} \mathrm{C}\right)$.

\subsubsection{Molhabilidade dos filmes (Ângulo de contato)}

A determinação de molhabilidade dos filmes foi realizada por medições de ângulo de contato com auxílio do equipamento OCA-20 Dataphysiscs (OCA 20, Dataphysiscs, Alemanha). As imagens de uma gota de água (tensão superficial $72,7 \mathrm{mN} / \mathrm{m}$ ) foram tomadas a cada 2 min em temperatura ambiente. Tomou-se o cuidado de deixar a superfície que foi exposta à secagem para a inserção da gota de água deionizada. O software de processamento de imagem GIMP 2.6.8 foi utilizado para medir o ângulo de contato, que foi identificado tangente à borda de queda, na interseção dos meios líquido, sólido e gasoso (Figura 3.4). Os valores dos ângulos 
de contato foram obtidos em triplicata (ângulos de contato foram medidos com deposição de gotas de água deionizada em diferentes regiões dos filmes).

Figura 3.4 - Esquema ilustrativo do ângulo de contato formado pela gota depositada sobre a superfície do filme

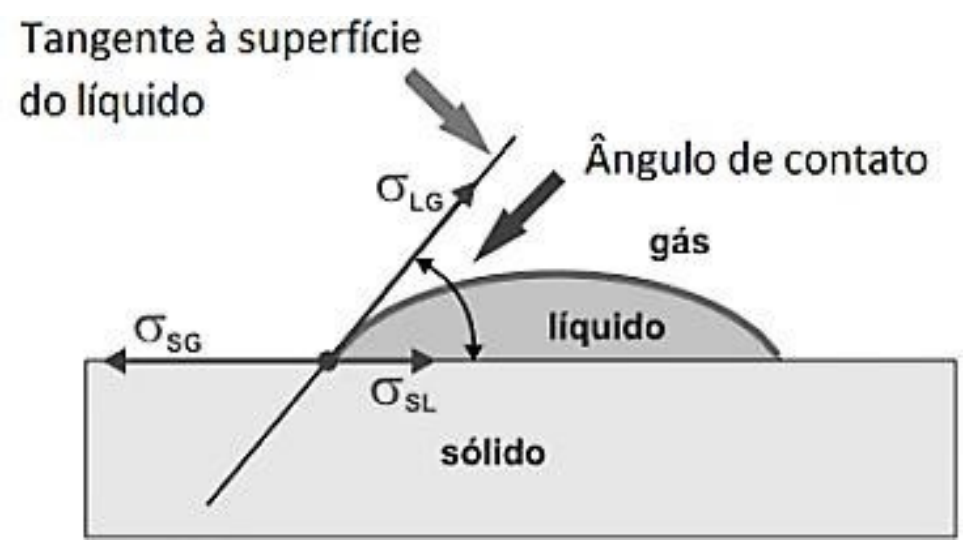

Fonte: LAI et al. (2016)

\subsubsection{Absorção de água}

As análises de absorção de água foram realizadas de acordo com Dufresne; Dupeyre ; Vignon (2000). As amostras de filmes $\left(20 \mathrm{~mm}\right.$ x $20 \mathrm{~mm}$ ) foram acondicionadas a $25{ }^{\circ} \mathrm{C} \mathrm{em}$ dessecador contendo solução saturada de sulfato de sódio (UR 95\%). Durante as primeiras 12 $\mathrm{h}$, as amostras foram pesadas a cada hora. Em seguida, foram pesadas a cada $12 \mathrm{~h}$ até o equilíbrio ser atingido. Este ensaio foi realizado em triplicata. A absorção de água foi calculada conforme a equação 2:

$$
\text { Absorção de água }=\frac{m t-m o}{m o} \times 100
$$

Sendo: mt: massa no tempo $\mathrm{t}$ (g); mo: massa do sólido seco após secagem durante 24 h a 105 ${ }^{\circ} \mathrm{C}$ (antes da exposição a 95\% de UR) 


\subsubsection{Análise estatística dos resultados}

Uma análise de variância (ANOVA) com um nível de significância de 5\% foi realizada para comparar os desvios médios das médias do efeito do tipo de farinha, $\mathrm{pH}$ e tempo de aquecimento sobre as propriedades dos filmes de farinha de urucum. Além disso, o teste de Tukey de comparações múltiplas foi realizado para comparar as propriedades dos filmes produzidos a partir dos três tipos de farinha. As análises estadísticas foram realizadas com o auxílio do software Statistica 6.0: ANOVA e Basic Statistics and Tables.

\subsection{Resultados e Discussão}

\subsubsection{Propriedades mecânicas}

Na Tabela 3.1 estão apresentados os valores de tensão e elongação na ruptura, e módulo de Young dos filmes de farinha de urucum produzidos segundo o planejamento fatorial completo $3 \times 3 \times 4$. Observa-se nesta tabela que houve uma diferença entre os valores de tensão, elongação e MY em função ao tipo de farinha, pH e tempo de aquecimento. Neste sentido, filmes produzidos com a farinha obtida por moagem alcalina (KS) apresentaram os maiores valores de tensão na ruptura $(3,6 \mathrm{MPa})$ em pH 5 e tempo de aquecimento de 2 horas. Nesta condição, os filmes também apresentaram o maior valor de MY (223,6 MPa), o qual indica que este filme de farinha extraída em $\mathrm{pH}$ alcalino nas condições de $\mathrm{pH} 5$ e tempo de aquecimento de 2 horas foi mais resistente e rígido mecanicamente. A farinha KS também permitiu obter filmes mais elongáveis $(41,3 \%)$ quando produzido em $\mathrm{pH} 7$ e tempo de aquecimento de 4 horas. Por outro lado, observou-se que os filmes produzidos a partir de farinha AS (pH ácido) mostraram-se menos resistentes mecanicamente e menos elongáveis quando produzidos em altos valores de pH ( 7 e 9) independente do tempo de aquecimento. Entretanto, os filmes de farinha AS mais elongáveis (31,58\%) foram obtidos em condições de $\mathrm{pH} 5$ e 2 horas de aquecimento. $\mathrm{O}$ pH alcalino (9) e tempo de 2 horas não favoreceu a formação de uma matriz elongável quando produzido a partir da farinha WS (meio neutro), pois este filme apresentouo menor valor de elongação $(0,9 \%)$ quando comparado aos outros filmes. 
Tabela 3.1 - Resultados das propriedades mecânicas dos filmes de farinha de urucum

\begin{tabular}{|c|c|c|c|c|c|c|c|c|c|c|}
\hline \multirow[t]{2}{*}{ pH } & \multirow{2}{*}{$\begin{array}{c}\text { Tempo } \\
\text { (h) }\end{array}$} & \multicolumn{3}{|c|}{ Tensão (MPa) } & \multicolumn{3}{|c|}{ Elongação (\%) } & \multicolumn{3}{|c|}{ Módulo de Young (MPa) } \\
\hline & & WS & AS & $\mathrm{KS}$ & WS & AS & $\mathrm{KS}$ & WS & AS & KS \\
\hline \multirow{4}{*}{5} & 1 & $0,3 \pm 0,2$ & $0,7 \pm 0,1$ & $2,7 \pm 0,6$ & $9,7 \pm 2,7$ & $2,30 \pm 4,74$ & $12,9 \pm 4,7$ & $15,2 \pm 4,9$ & $17,1 \pm 1,5$ & $164,0 \pm 0,1$ \\
\hline & 2 & $0,5 \pm 0,1$ & $0,7 \pm 0,1$ & $3,6 \pm 0,6$ & $21,6 \pm 2,0$ & $31,58 \pm 1,73$ & $7,0 \pm 2,1$ & $7,9 \pm 0,8$ & $20,9 \pm 2,4$ & $223,6 \pm 13,8$ \\
\hline & 3 & $0,7 \pm 0,1$ & $0,7 \pm 0,2$ & $1,5 \pm 0,2$ & $23,0 \pm 2,7$ & $14,05 \pm 2,95$ & $13,9 \pm 1,4$ & $22,2 \pm 0,9$ & $34,3 \pm 5,0$ & $45,2 \pm 4,9$ \\
\hline & 4 & $0,7 \pm 0,2$ & $1,4 \pm 0,1$ & $1,7 \pm 0,3$ & $15,5 \pm 2,1$ & $21,19 \pm 1,37$ & $17,9 \pm 4,8$ & $18,9 \pm 3,5$ & $50,3 \pm 4,4$ & $52,4 \pm 8,3$ \\
\hline \multirow{4}{*}{7} & 1 & $0,7 \pm 0,6$ & $0,2 \pm 0,1$ & $0,6 \pm 0,2$ & $13,5 \pm 2,0$ & $6,5 \pm 3,9$ & $23,3 \pm 2,1$ & $57,7 \pm 41,6$ & $4,5 \pm 1,1$ & $16,1 \pm 5,4$ \\
\hline & 2 & $0,8 \pm 0,3$ & $0,4 \pm 0,2$ & $0,3 \pm 0,1$ & $13,6 \pm 6,8$ & $6,9 \pm 1,8$ & $22,3 \pm 4,4$ & $30,0 \pm 11,7$ & $9,1 \pm 2,1$ & $3,2 \pm 0,9$ \\
\hline & 3 & $0,5 \pm 0,2$ & $0,2 \pm 0,1$ & $0,8 \pm 0,1$ & $22,0 \pm 8,0$ & $8,2 \pm 1,7$ & $29,5 \pm 2,5$ & $14,7 \pm 1,5$ & $4,0 \pm 0,9$ & $18,5 \pm 4,3$ \\
\hline & 4 & $0,6 \pm 0,1$ & $0,2 \pm 0,2$ & $0,7 \pm 0,1$ & $20,5 \pm 2,9$ & $5,7 \pm 0,6$ & $41,3 \pm 3,2$ & $15,3 \pm 3,7$ & $5,9 \pm 1,1$ & $14,9 \pm 3,5$ \\
\hline \multirow{4}{*}{9} & 1 & $0,4 \pm 0,2$ & $0,7 \pm 0,5$ & $0,5 \pm 0,1$ & $6,2 \pm 2,6$ & $4,2 \pm 0,8$ & $27,0 \pm 5,5$ & $4,6 \pm 3,3$ & $30,9 \pm 4,6$ & $8,6 \pm 1,1$ \\
\hline & 2 & $0,3 \pm 0,2$ & $0,5 \pm 0,3$ & $1,1 \pm 0,6$ & $0,9 \pm 0,2$ & $7,2 \pm 3,5$ & $12,2 \pm 1,2$ & $42,3 \pm 2,1$ & $27,3 \pm 9,7$ & $52,4 \pm 6,8$ \\
\hline & 3 & $1,3 \pm 0,3$ & $0,2 \pm 0,1$ & $1,9 \pm 0,3$ & $19,5 \pm 2,5$ & $3,6 \pm 0,4$ & $26,2 \pm 3,2$ & $43,9 \pm 2,7$ & $9,0 \pm 4,0$ & $188,1 \pm 26,6$ \\
\hline & 4 & $0,9 \pm 0,1$ & $0,3 \pm 0,1$ & $1,6 \pm 0,4$ & $25,0 \pm 1,7$ & $5,5 \pm 1,4$ & $20,8 \pm 3,0$ & $16,3 \pm 2,9$ & $13,0 \pm 1,4$ & $83,7 \pm 19,3$ \\
\hline
\end{tabular}


Os resultados mostrados na Tabela 3.1 foram analisados estatisticamente usando o software STATISTICA 6.0. Os valores de "p" obtidos na Análise de Variança (ANOVA) são mostrados na Tabela 3.2.

Tabela 3.2 - Valores de "p" da tabela da ANOVA para as propriedades mecânicas

\begin{tabular}{cccc}
\hline Efeitos & Tensão & Elongação & MY \\
\hline tipo de farinha & $0,0001^{*}$ & $0,0001^{*}$ & $0,0001^{*}$ \\
pH & $0,0001^{*}$ & $0,0001^{*}$ & $0,0001^{*}$ \\
tempo & $0,00001^{*}$ & $0,0001^{*}$ & $0,0001^{*}$ \\
tipo de farinha x pH & $0,0001^{*}$ & $0,0001^{*}$ & $0,0001^{*}$ \\
tipo de farinha x tempo & $0,00001^{*}$ & $0,0001^{*}$ & $0,0001^{*}$ \\
pH x tempo & $0,0001^{*}$ & $0,00001^{*}$ & $0,0001^{*}$ \\
tipo de farinha x pH x tempo & $0,0001^{*}$ & $0,00001^{*}$ & $0,0001^{*}$ \\
\hline
\end{tabular}

(*) para $\mathrm{p}<0,05$ o efeito da variável foi significativo.

MY: Módulo de Young

De acordo à Tabela 3.2, o tipo de farinha, $\mathrm{pH}$ e tempo de aquecimento e todas as interações tiveram efeito significativo sobre a tensão na ruptura, elongação e módulo de Young dos filmes de farinha de urucum $(\mathrm{p}<0,05)$. Isto é, uma mudança nos valores destas variáveis produz um aumento ou diminuição nos valores das propriedades mecânicas.

O efeito destas variáveis sobre as propriedades mecânicas dos filmes pode ser justificado em função ao tipo de ligações moleculares que podem ser formadas quando muda- se o valor de $\mathrm{pH}$ da suspensão e tempo de aquecimento para a formação da solução filmogênica, além do efeito da composição das farinhas WS, AS e KS.

O tipo de farinha pode ter influenciado na tensão na ruptura do filme devido à diferença na composição destas farinhas, como mostrado no capítulo 2. Foi observado que o método de moagem em pH alcalino (KS) foi o mais eficiente na remoção de proteínas e lipídeos permitindo obter farinha com maior grau de pureza e maior teor de amilose. De acordo com a literatura, o maior grau de pureza e maior teor de amilose permitem a formação de uma matriz mais coesa, devido à maiores interações entre amilose-amilose, amilopectina-amilopectina, amiloseamilopectina, possibilitando a formação de filme mais resistente (MALI; GROSSMANN; YAMASHITA, 2010; PELISSARI et al., 2012).

Por outro lado, como as farinhas de urucum aqui trabalhadas contêm proteínas, lipídeos, fibras e compostos ativos. Logo, o ajuste de $\mathrm{pH}$ se faz importante para a homogeneização da matriz que será constituída. Assim, o pH teve efeito importante na tensão de ruptura, ao verificar 
que os filmes de farinha KS em pH 5 apresentaram maiores valores de tensão. A farinha KS tem maior teor de amilose e maior grau de pureza. Em pH 5, podem ocorrer hidrólises das fibras contidas nesta farinha permitindo a entrada de água para a gelatinização dos grânulos de amido, consequentemente há maiores interações amido-amido, amido-proteína na matriz e a formação de um filme mais resistente (SUN et al., 2004).

Em geral, a tensão na ruptura é influenciada pela interação entre as proteínas na matriz filmogênica. $\mathrm{O}$ pH 5 está próximo ao ponto isoelétrico das proteínas presentes na farinha de urucum. Logo, em pH 5 as interações eletrostáticas são mínimas, proporcionando um maior número de ligações covalentes S-S das proteínas na matriz filmogênica, promovendo então a formação de filmes mais resistentes, como mencionado por Alting et al. (2000; 2002; 2003).

$\mathrm{O}$ aumento do $\mathrm{pH}$ aumentou os valores de tensão na ruptura dos filmes de farinha de urucum. Em valores de $\mathrm{pH}$ de 7 a 9, ocorre forte repulsão eletrostática intramolecular causada pela alta carga líquida, resultando no desdobramento das estruturas proteícas e maior solubilidade (DAMODARAN, 2010). Tal fato, explica os menores valores da tensão na ruptura dos filmes com o aumento do pH. Este comportamento está de acordo com Yoshida, (2002) que estudou a influência do $\mathrm{pH}$ nas propriedades de filmes de proteínas do soro de leite, foi verificada redução na tensão de ruptura com o aumento do pH. Souza, (2012) avaliou o efeito de diferentes valores de $\mathrm{pH}$ nas propriedades de filmes de soro de leite e também foi verificada redução na tensão de ruptura com aumento de $\mathrm{pH}$.

$\mathrm{O}$ pH também interfere nos carotenóides, já que estes são estáveis em faixas de $\mathrm{pH}$ de 3 a 7. Em pH extremo os carotenóides podem sofrer isomerização cis/trans de certas duplas ligações, assim como saponificação (RIBEIRO \& SERAVALLI, 2004).

As Figuras 3.5 e 3.6 confirmam que o tipo de farinha apresentou maior efeito sobre a tensão na ruptura e módulo de Young, pois a farinha KS permitiu obter filmes com maior resistência mecânica e mais rígidos, principalmente em pH 5 (Figura 3.5A). O efeito do tempo de aquecimento sobre a tensão na ruptura foi mais evidente nos filmes de farinha KS produzidos em pH 5 e pH 9, mas com diferente comportamento. Os filmes KS produzidos em até 2 horas de aquecimento apresentaram maior tensão na ruptura em $\mathrm{pH} 5$, mas em $\mathrm{pH} 9$ precisou-se de maior tempo para produzir filmes mais resistentes mecanicamente (3 horas). Portanto, o filme de farinha de urucum mais resistente mecanicamente foi obtido quando utilizado farinha isolada em meio alcalino (KS), pH 5 e tempo de aquecimento de 2 horas. 
Figura 3.5 - Tensão dos filmes de farinha de urucum isolados por métodos WS, AS e KS elaborados em diferentes $\mathrm{pH}(5,7,9)$ e tempo de aquecimento (1h, $2 \mathrm{~h}, 3 \mathrm{~h}, 4 \mathrm{~h})$

(A)

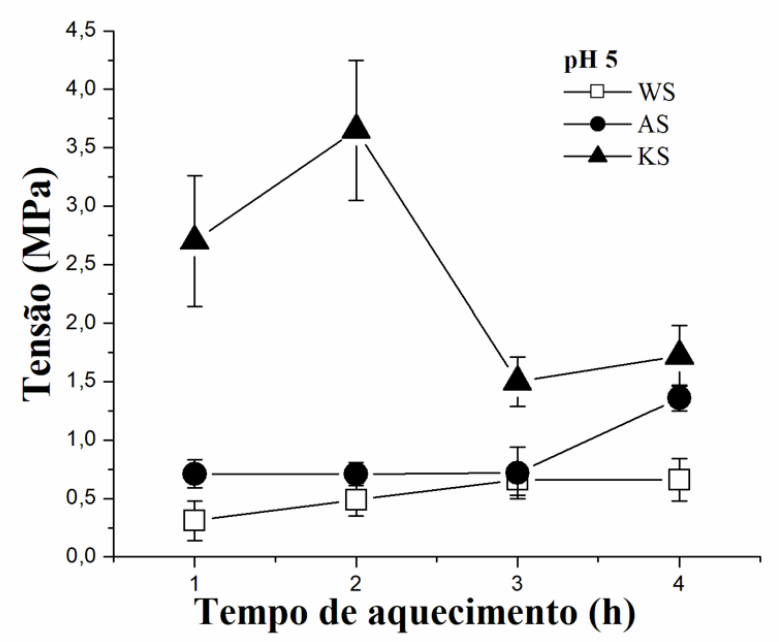

(B)

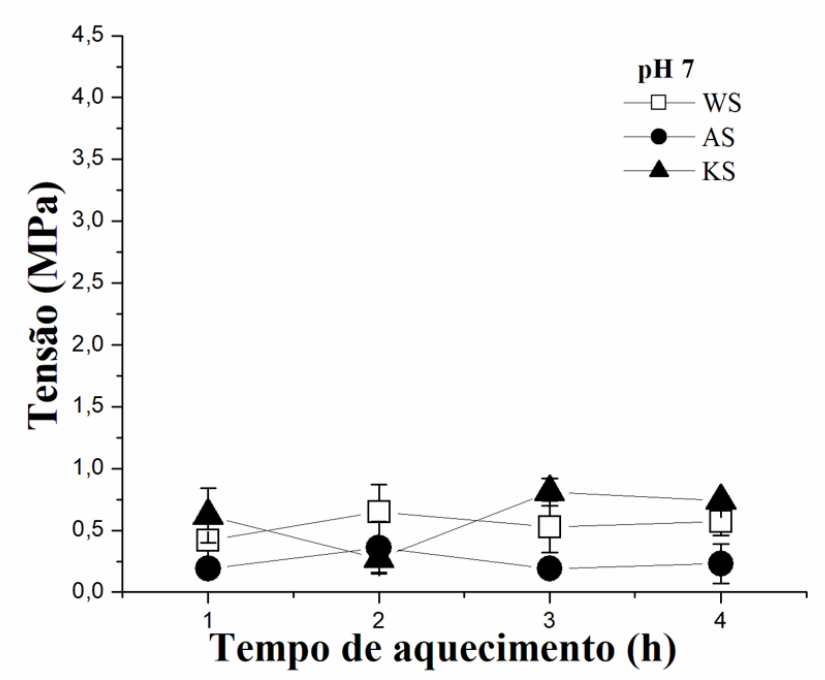

(C)

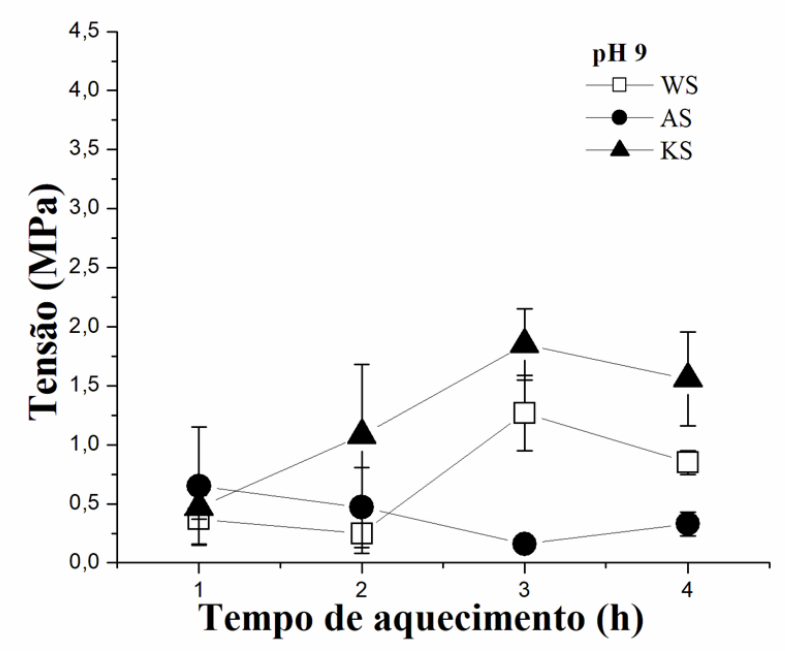


Figura 3.6 - Módulo de Young dos filmes de farinha de urucum isolados por método WS, AS e KS elaborados em diferentes $\mathrm{pH}(5,7,9)$ e tempo de aquecimento $(1 \mathrm{~h}, 2 \mathrm{~h}, 3 \mathrm{~h}, 4 \mathrm{~h})$

(A)

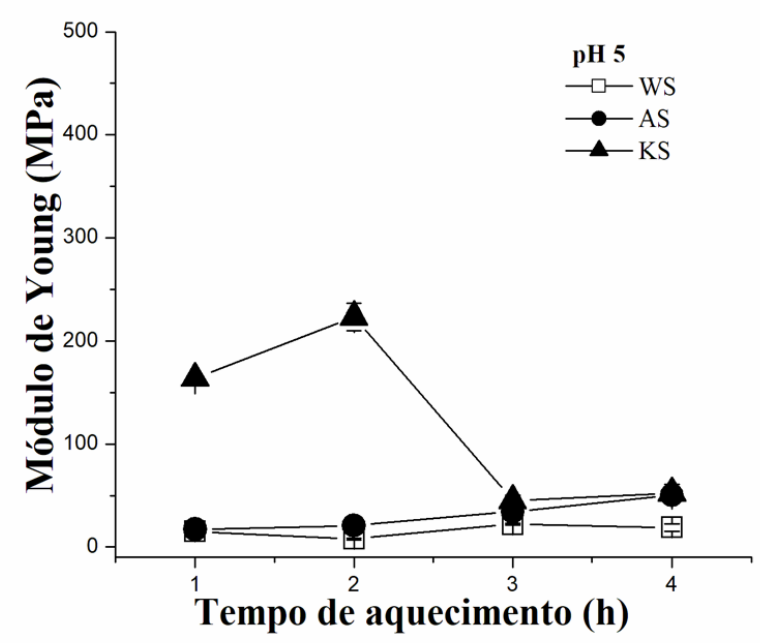

(B)

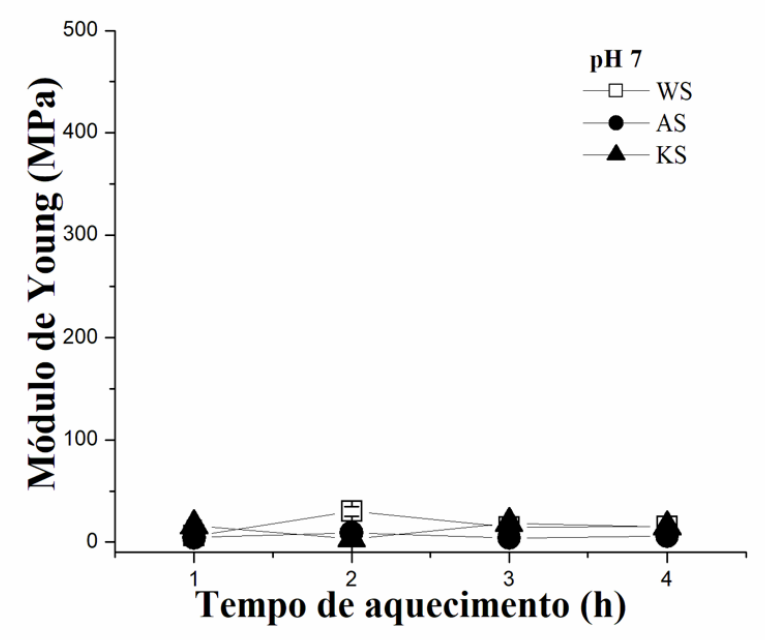

(C)

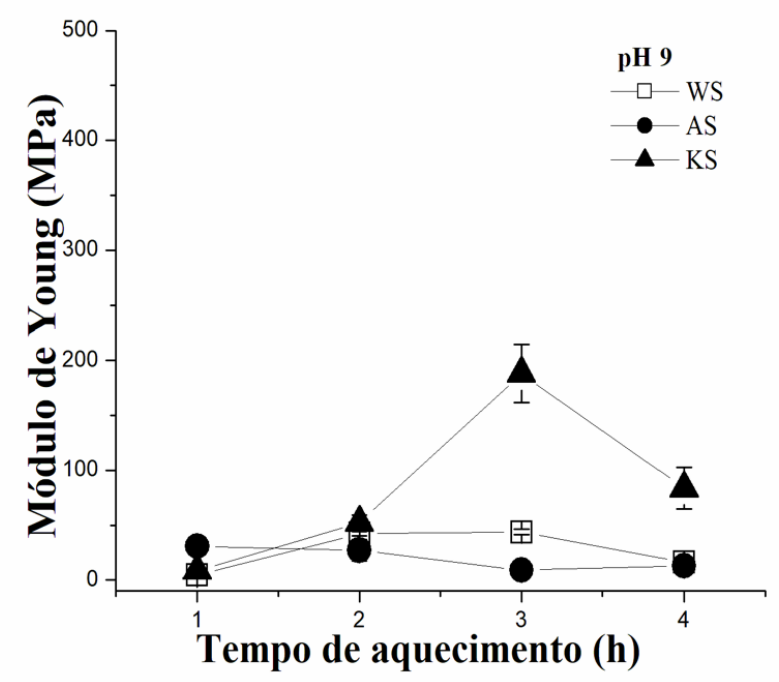


Os filmes de farinha KS, em $\mathrm{pH} 7$ e 4 horas de aquecimento apresentaram-se mais elongáveis (Figura 3.7B). O pH 7 pode ter favorecido a maior exposição dos grupos sulfidrilas (SH) na superfície, consequentemente há um aumento das ligações covalentes dissulfídicas(SS) nos filmes, caracterizando-se pela formação de filmes mais elongáveis (YOSHIDA, 2002). O mesmo foi discutido e sugerido por Fairley et al. (1996) onde grupos SH livres foram responsáveis pela elongação de filmes de isolado proteíco de soro de leite, como também observado por Soares, (2012) em filmes biodegradáveis de proteínas do soro de leite..

Os filmes produzidos de farinhas WS e AS, em pH 5 e 2 horas de aquecimento apresentaram melhores valores de elongação em relação aos demais valores de pH (Figuras 3.7 A). As farinhas WS e AS contem menor teor de amido do que a farinha KS, nelas estão presentes proteínas e lipídeos, estes podem atuar como plastificantes, aumentando a elongação. Nota-se que em pH 9, os valores de elongação para os mesmos são menores. Em pH alcalino ocorre saponificação dos lipídeos e a solubilização das proteínas, reduzindo o efeito plastificante dessas macromoléculas.

No geral, independente da farinha (WS, AS, KS), pH e tempo de aquecimento, os filmes obtidos tiveram baixa resistência mecânica, mas foram filmes flexíveis. 
Figura 3.7 - Elongação dos filmes de farinha de urucum isolados por método WS, AS e KS elaborados em diferentes $\mathrm{pH}(5,7,9)$ e tempo de aquecimento (1h, $2 \mathrm{~h}, 3 \mathrm{~h}, 4 \mathrm{~h})$

(A)

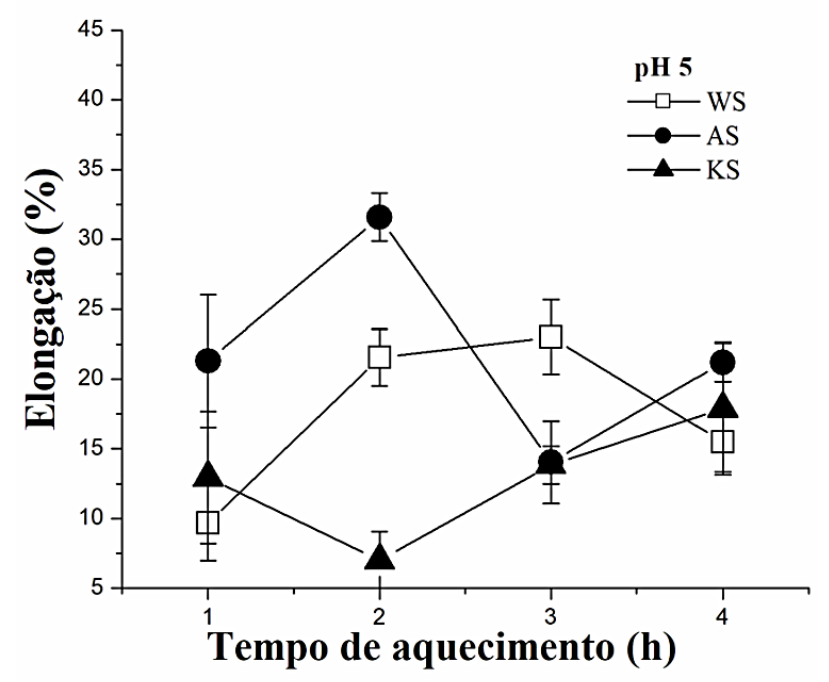

(B)

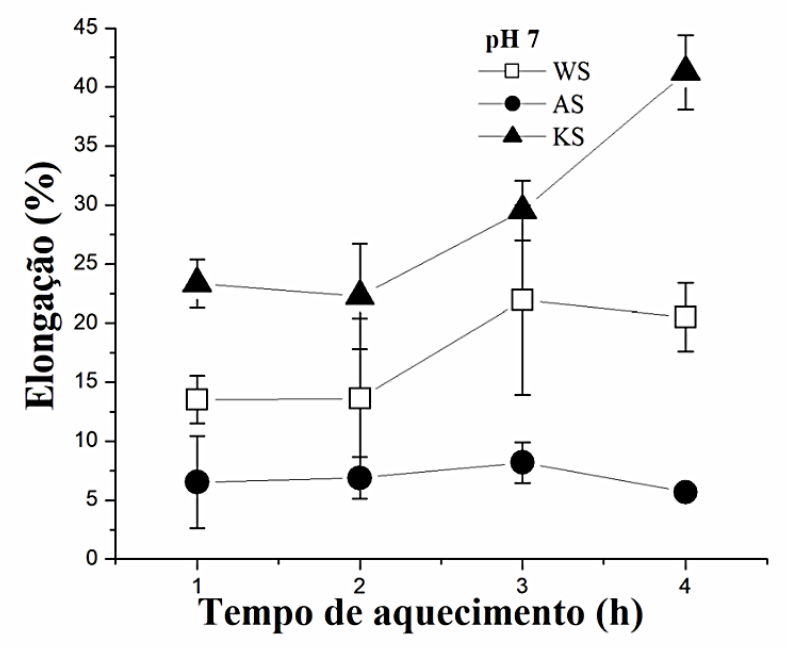

(C)

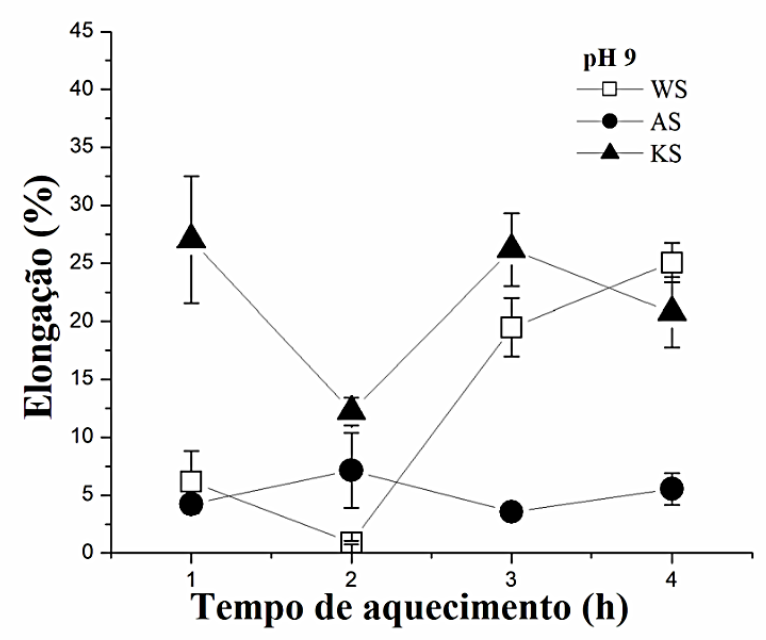




\subsubsection{Propriedades funcionais}

Na Tabela 3.3 estão apresentados os valores de umidade, solubilidade e permeabilidade ao vapor de água dos filmes de farinha de urucum produzidos segundo o planejamento fatorial completo $3 \times 3 \times 4$. Observa-se nesta tabela que houve uma diferença entre os valores de umidade, solubilidade e permeabilidade ao vapor de água em função ao tipo de farinha, $\mathrm{pH}$ e tempo de aquecimento. Neste sentido os filmes produzidos com farinha obtida por moagem (WS) e por moagem (AS) apresentaram se mais úmidos $(23,0 \%)$ e $(24,6 \%)$ em pH 5 e tempo de aquecimento de 2 horas. No geral, os filmes tiveram suas solubilidades aumentadas com aumento do $\mathrm{pH}$ ( 5 a 9), indicando que os filmes elaborados em pH 5 são menos solúveis. $\mathrm{O}$ pH exerceu forte influência sobre os valores de permeabilidade ao vapor de água ao analisar filmes de mesmas farinhas com diferentes comportamentos de acordo com o $\mathrm{pH}$. Em $\mathrm{pH}$ 5, para filmes de farinha WS foi observada maior permeabilidade ao vapor de água $\left(7,3 \times 10^{-10} \cdot \mathrm{g}^{\mathrm{m}} \mathrm{m}^{-1} \mathrm{~h}^{-1} \cdot \mathrm{KPa}\right)$. O filme de farinha WS em pH 7 apresentou menor permeabilidade $\left(3,3 \times 10^{-10} \cdot g \cdot \mathrm{m}^{-1} \mathrm{~h}^{-1} \cdot \mathrm{KPa}\right)$. Em pH 9, para farinhas WS e AS foram obtidos maiores valores de permeabilidade ao vapor de água $\left(6,3 \times 10^{-10} \cdot \mathrm{g} \cdot \mathrm{m}^{-1} \mathrm{~h}^{-1} \cdot \mathrm{KPa}\right.$ e $\left.9,8 \times 10^{-10} \cdot \mathrm{g} \cdot \mathrm{m}^{-1} \mathrm{~h}^{-1} \cdot \mathrm{KPa}\right)$. 
Tabela 3.3 - Resultados das propriedades funcionais dos filmes de farinha de urucum

\begin{tabular}{|c|c|c|c|c|c|c|c|c|c|c|}
\hline \multirow[t]{3}{*}{ pH } & \multirow{2}{*}{$\begin{array}{c}\text { Temp } \\
\text { o } \\
\text { (h) }\end{array}$} & \multicolumn{3}{|c|}{ Umidade (\%) } & \multicolumn{3}{|c|}{ Solubilidade (\%) } & \multicolumn{3}{|c|}{ PVA (*) } \\
\hline & & WS & AS & KS & WS & AS & KS & WS & AS & KS \\
\hline & 1 & $23,6 \pm 0,4$ & $25,3 \pm 0,1$ & $20,2 \pm 0,1$ & $63,9 \pm 0,1$ & $54,90 \pm$ & $37,2 \pm 0,8$ & $6,9 \pm 1,2$ & $2,4 \pm 0,5$ & $3,4 \pm 0,1$ \\
\hline \multirow[t]{5}{*}{5} & 2 & $23,0 \pm 0,7$ & $24,1 \pm 0,1$ & $21,7 \pm 0,7$ & $54,6 \pm 2,4$ & 1,5 & $38,1 \pm 3,0$ & $7,3 \pm 0,6$ & $2,4 \pm 0,3$ & $3,4 \pm 0,3$ \\
\hline & 3 & $24,4 \pm 0,1$ & $23,5 \pm 0,2$ & $20,6 \pm 0,3$ & $65,9 \pm 4,1$ & $60,9 \pm 2,6$ & $35,2 \pm 0,3$ & $6,2 \pm 1,3$ & $2,3 \pm 0,3$ & $2,7 \pm 0,9$ \\
\hline & 4 & $23,6 \pm 0,4$ & $26,8 \pm 0,5$ & $20,3 \pm 2,2$ & $56,3 \pm 1,6$ & $48,9 \pm 2,1$ & $39,0 \pm 4,8$ & $6,5 \pm 0,8$ & $3,9 \pm 0,2$ & $3,8 \pm 0,2$ \\
\hline & & & & & & $48,4 \pm 1,9$ & & & & \\
\hline & 1 & $19,7 \pm 0,8$ & $30,4 \pm 2,3$ & $27,1 \pm 0,7$ & $44,5 \pm 2,2$ & $55,1 \pm 5,1$ & $58,7 \pm 1,5$ & $3,4 \pm 1,5$ & $5,1 \pm 1,2$ & $4,4 \pm 0,9$ \\
\hline \multirow[t]{4}{*}{7} & 2 & $15,3 \pm 0,9$ & $26,9 \pm 1,4$ & $26,8 \pm 0,1$ & $76,4 \pm 11,5$ & $63,9 \pm 5,1$ & $53,5 \pm 0,6$ & $3,3 \pm 0,8$ & $6,1 \pm 0,7$ & $9,0 \pm 0,7$ \\
\hline & 3 & $21,0 \pm 0,6$ & $31,6 \pm 1,9$ & $28,4 \pm 0,1$ & $59,9 \pm 0,6$ & $57,1 \pm 5,1$ & $43,6 \pm 0,1$ & $3,1 \pm 0,2$ & $7,1 \pm 4,0$ & $4,5 \pm 0,2$ \\
\hline & 4 & $20,9 \pm 0,3$ & $26,4 \pm 0,6$ & $24,2 \pm 0,3$ & $65,4 \pm 2,1$ & $51,9 \pm 6,1$ & $40,2 \pm 0,4$ & $3,3 \pm 0,8$ & $7,1 \pm 1,5$ & $4,6 \pm 0,9$ \\
\hline & 1 & $28,4 \pm 0,6$ & $23,8 \pm 1,2$ & $23,5 \pm 0,4$ & $73,4 \pm 2,4$ & $91,8 \pm 1,1$ & $62,1 \pm 1,5$ & $6,3 \pm 0,8$ & $5,2 \pm 0,9$ & $3,9 \pm 0,5$ \\
\hline \multirow[t]{3}{*}{9} & 2 & $18,1 \pm 1,3$ & $22,9 \pm 0,5$ & $17,0 \pm 0,1$ & $63,9 \pm 11,6$ & $77,1 \pm 1,8$ & $55,5 \pm 0,6$ & $3,8 \pm 0,4$ & $3,0 \pm 1,1$ & $6,2 \pm 1,2$ \\
\hline & 3 & $18,1 \pm 0,2$ & $30,4 \pm 0,7$ & $18,3 \pm 0,7$ & $55,9 \pm 5,4$ & $58,3 \pm 2,1$ & $49,6 \pm 0,1$ & $4,3 \pm 0,8$ & $9,8 \pm 0,4$ & $6,7 \pm 0,8$ \\
\hline & 4 & $20,9 \pm 0,3$ & $28,8 \pm 1,5$ & $47,3 \pm 0,9$ & $59,9 \pm 2,6$ & $72,5 \pm 8,4$ & $45,2 \pm 0,4$ & $5,1 \pm 0,2$ & $7,9 \pm 1,4$ & $7,4 \pm 1,6$ \\
\hline
\end{tabular}

PVA: permeabilidade ao vapor de água.

$(*)$ : expresso em $\left(10^{-10} \cdot \mathrm{g} \cdot \mathrm{m}^{-1} \mathrm{~h}^{-1} \cdot \mathrm{KPa}\right)$ 
Os resultados mostrados na Tabela 3.3 foram analisados estatisticamente usando o software STATISTICA 6.0. Os valores de "p" obtidos na Análise de Variança (ANOVA) são mostrados na Tabela 3.4.

Tabela 3.4 - Valores de "p" da tabela da ANOVA para propriedades funcionais

\begin{tabular}{cllc}
\hline Efeitos & Umidade & Solubilidade & PVA \\
\hline tipo de farinha & $0,000001^{*}$ & $0,000000^{*}$ & 0,985080 \\
pH & $0,018896^{*}$ & $0,000004^{*}$ & $0,000087^{*}$ \\
Tempo & $0,023514^{*}$ & $0,004681^{*}$ & $0,013223^{*}$ \\
tipo de farinha x pH & $0,000274^{*}$ & $0,004969^{*}$ & 0,000000 \\
tipo de farinha x tempo & 0,141027 & 0,280012 & $0,000013^{*}$ \\
pH x tempo & $0,002042^{*}$ & 0,093984 & $0,000317^{*}$ \\
tipo de farinha x pH x tempo & $0,000200^{*}$ & $0,006526^{*}$ & $0,048127^{*}$ \\
\hline
\end{tabular}

$(*)$ para $\mathrm{p}<0,05$ o efeito da variável foi significativo.

MY: Módulo de Young

De acordo à Tabela 3.4, o tipo de farinha, $\mathrm{pH}$ e tempo de aquecimento tiveram efeito significativo sobre a umidade, solubilidade e permeabilidade ao vapor de água dos filmes de farinha de urucum $(\mathrm{p}<0,05)$. Isto é, uma mudança nos valores destas variáveis produz um aumento ou diminuição nos valores das propriedades funcionais. Também se observa que o tipo de farinha foi a variável mais significativa sobre a solubilidade e a umidade. Entretanto, o $\mathrm{pH}$ foi a a variável mais significativa sobre o valor de permeabilidade ao vapor de água dos filmes de farinha de urucum. As interações tipo de farinha $\mathrm{x} \mathrm{pH}$, tipo de farinha $\mathrm{x}$ tempo e $\mathrm{pH} \mathrm{x}$ tempo também apresentaram maior efeito sobre a permeabilidade ao vapor de água (PVA). A interação tipo de farinha $\mathrm{x} \mathrm{pH} \mathrm{x}$ tempo apresentou efeito mais significativa sobre a solubilidade dos filmes de farinha de urucum. Por outro lado, as interações farinha $\mathrm{x}$ tempo não apresentou efeito significativo sobre a umidade e solubilidade dos filmes de farinha de urucum, assim como a interação $\mathrm{pH}$ x tempo sobre a solubilidade.

O teor de umidade nos filmes está ligado à composição química das farinhas. Com foi apresentado no capítulo 2, as farinhas apresentaram grau de pureza em amido, em torno de $65 \%$, e a presença de outros componentes hidrofílicos como proteínas e fibras na matriz filmogênica pode favorecer um maior número de interações com moléculas de água tornando este material mais hidrofílico (PELISSARI et al., 2013). 
A solubilidade dos filmes em água está relacionada diretamente com as interações intermoleculares entre seus componentes, de acordo com sua estrutura e suas características químicas como hidrofilicidade e hidrofobicidade (FERREIRA, 2006).

Ao analisar os resultados de solubilidade na Tabela 3.3 observa-se que a solubilidade média dos filmes de farinha de urucum WS, AS e KS aumentou com o aumento do pH de 5 a 9 (Figura 3.9). De acordo com Gennadios et al. (1994), a variação de pH $(5,0$ a 10,0) da solução filmogênica, permitiu um aumento na força iônica ou adição de íons que contribuiu para o aumento da solubilidade dos filmes de proteínas de vegetais e animais.

Os filmes elaborados em pH 5 apresentaram médias de solubilidade inferiores aos demais (Figura 3.9 A). Isto pode ser devido a que $\mathrm{pH}$ próximo a 5 é próximo ao ponto isoelétrico das proteínas, logo as proteínas na farinha tendem a se agregar, formando redes e não solubilizam. Valério et al. (2015), avaliou o perfil de solubilidade das proteínas contidas na

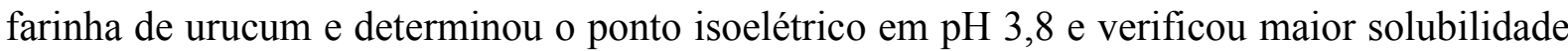
das proteínas em $\mathrm{pH}$ 12. Fora do ponto isoelétrico, a proteína possuí carga positiva e negativa em excesso, que vão interagir com a molécula de água, contribuindo para a solubilização (SGARBIERI, 1996). O aumento da densidade de cargas da proteína, em valores de $\mathrm{pH}$ afastados da região do ponto isoelétrico, como é o caso dos filmes produzidos com ajuste de $\mathrm{pH}$ (7 e 9), favorecem as interações proteína-água resultando em um aumento das propriedades de hidratação e consequentemente há um aumento na solubilidade (DAMODARAM, 1996).

Segundo Bemiller (1993) em pH ácido pode ocorrer hidrólise das ligações glicosídicas/peptídicas resultando em fragmentos menores, o que poderia criar espaços vazios na rede do filme, explicando o aumento nos valores de PVA nesta condição de pH (Figura 3.10). Este fato justifica a maior permeabilidade ao vapor de água do filme de farinha WS em $\mathrm{pH} 5$ (Figura 3.10 A). A menor permeabilidade ao vapor de água dos filmes de farinhas AS e KS em pH 5 pode estar associada à presença de proteínas e lipídeos em maior quantidade nestas farinhas. Neste caso, o lipídeo atua como uma barreira, preenchendo os poros e impedindo a passagem de água (GARCIA; MARTINO; ZARITZKY, 2000). A permeabilidade ao vapor de água do filme de farinha $\mathrm{KS}$ em $\mathrm{pH} 5$ é devido a rede mais compacta já que a farinha KS é a mais rica em amilose.

A menor permeabilidade ao vapor de água do filme de farinha WS em $\mathrm{pH} 7$ pode estar associada à maior presença de fibras nesta farinha (Figura 3.6 B). Neste caso, as fibras criam uma tortuosidade nesta matriz, evitando a difusão de vapor de água através da matriz e diminuindo o 
PVA (GARCÍA et al., 2009; MA et al., 2008). Em pH 9, para farinhas WS e AS foram obtidos maiores valores de permeabilidade ao vapor de água (Figura 3.10 C). Neste pH, pode ocorrer a saponificação de lipídeos e a solubilização de proteínas, logo pode haver espaços vazios na rede polimérica, antes ocupados por essas macromoléculas. 
Figura 3.8 - Umidade dos filmes de farinha de urucum isolados por método WS, AS e KS elaborados em diferentes $\mathrm{pH}(5,7,9)$ e tempo de aquecimento (1h, $2 \mathrm{~h}, 3 \mathrm{~h}, 4 \mathrm{~h})$

(A)

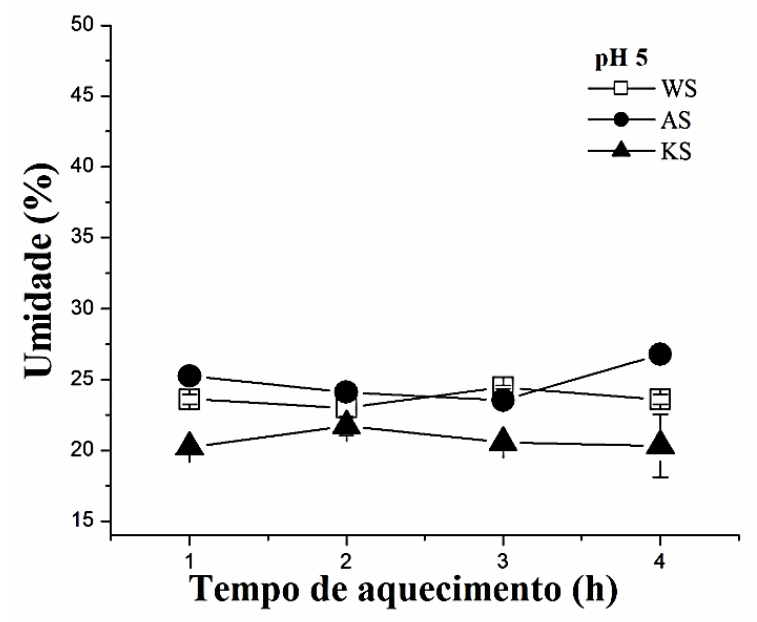

(B)

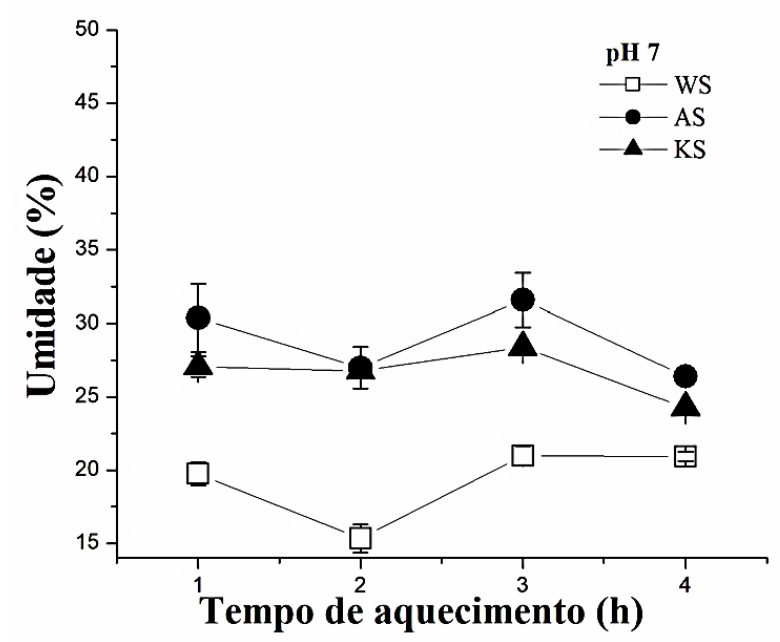

(C)

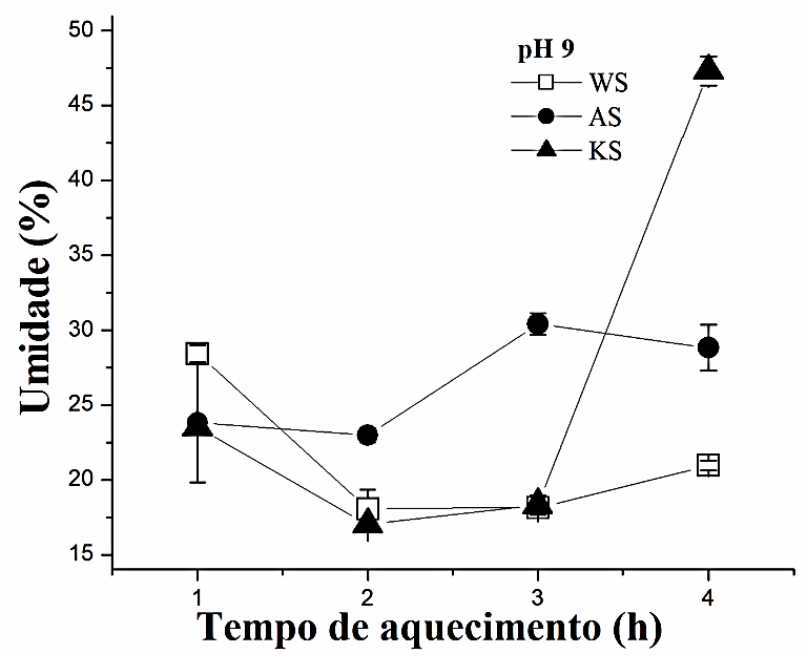


Figura 3.9 - Solubilidade dos filmes de farinha de urucum isolados por método WS, AS e KS elaborados em diferentes $\mathrm{pH}(5,7,9)$ e tempo de aquecimento $(1 \mathrm{~h}, 2 \mathrm{~h}, 3 \mathrm{~h}, 4 \mathrm{~h})$

(A)

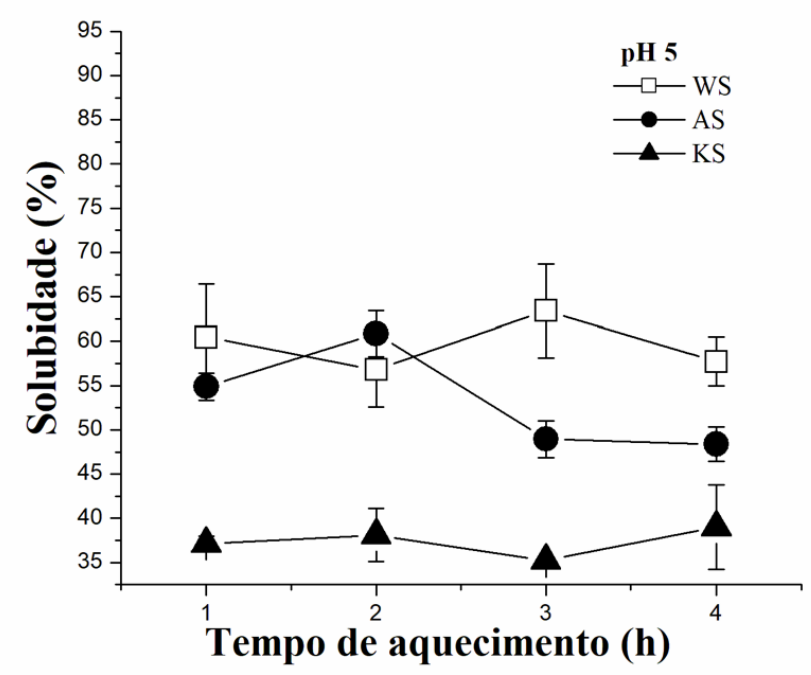

(B)

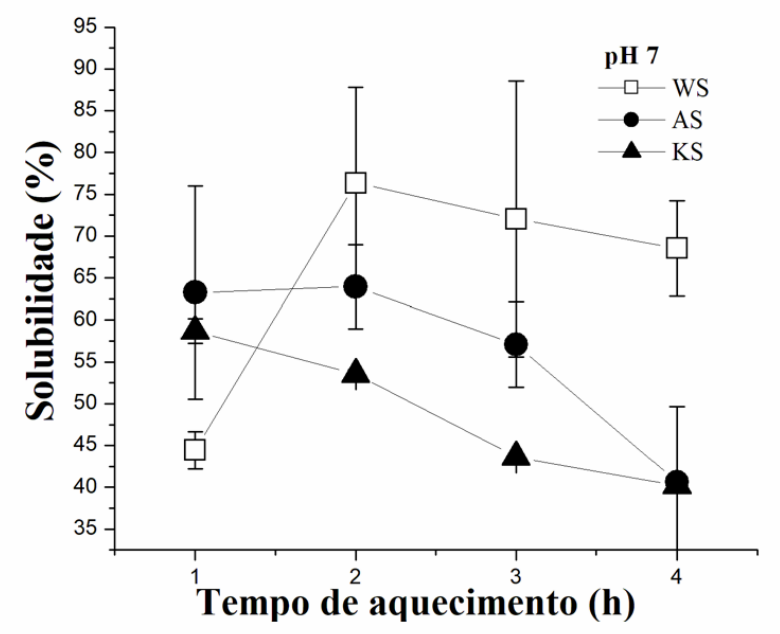

(C)

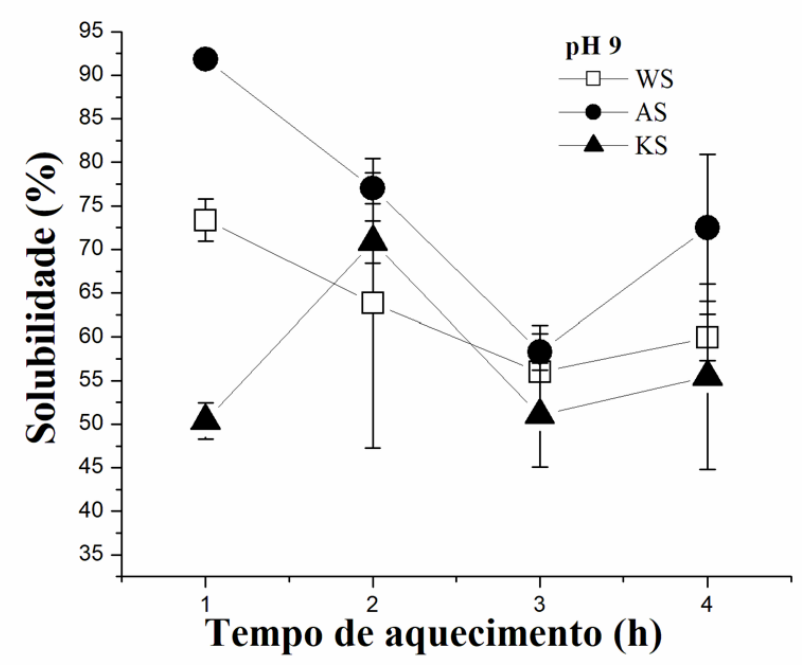


Figura 3.10 - PVA dos filmes de farinha de urucum isolados por método WS, AS e KS elaborados em diferentes $\mathrm{pH}(5,7,9)$ e tempo de aquecimento $(1 \mathrm{~h}, 2 \mathrm{~h}, 3 \mathrm{~h}, 4 \mathrm{~h})$

(A)

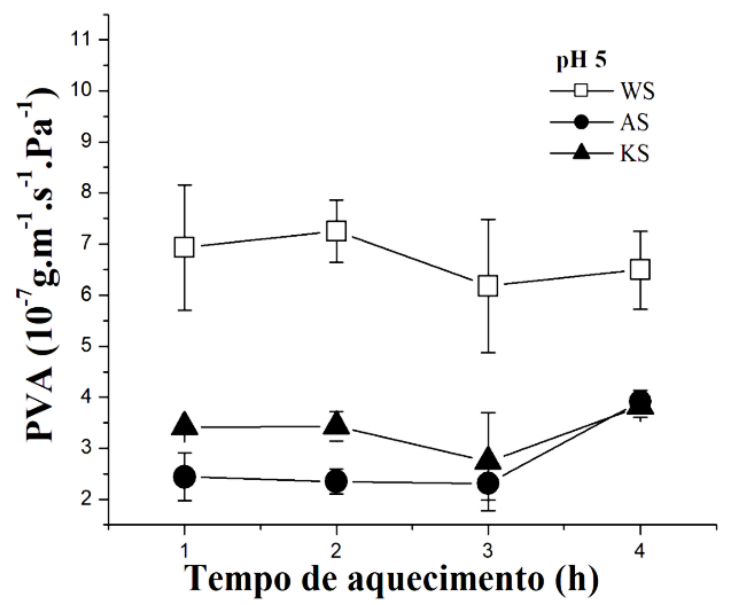

(B)
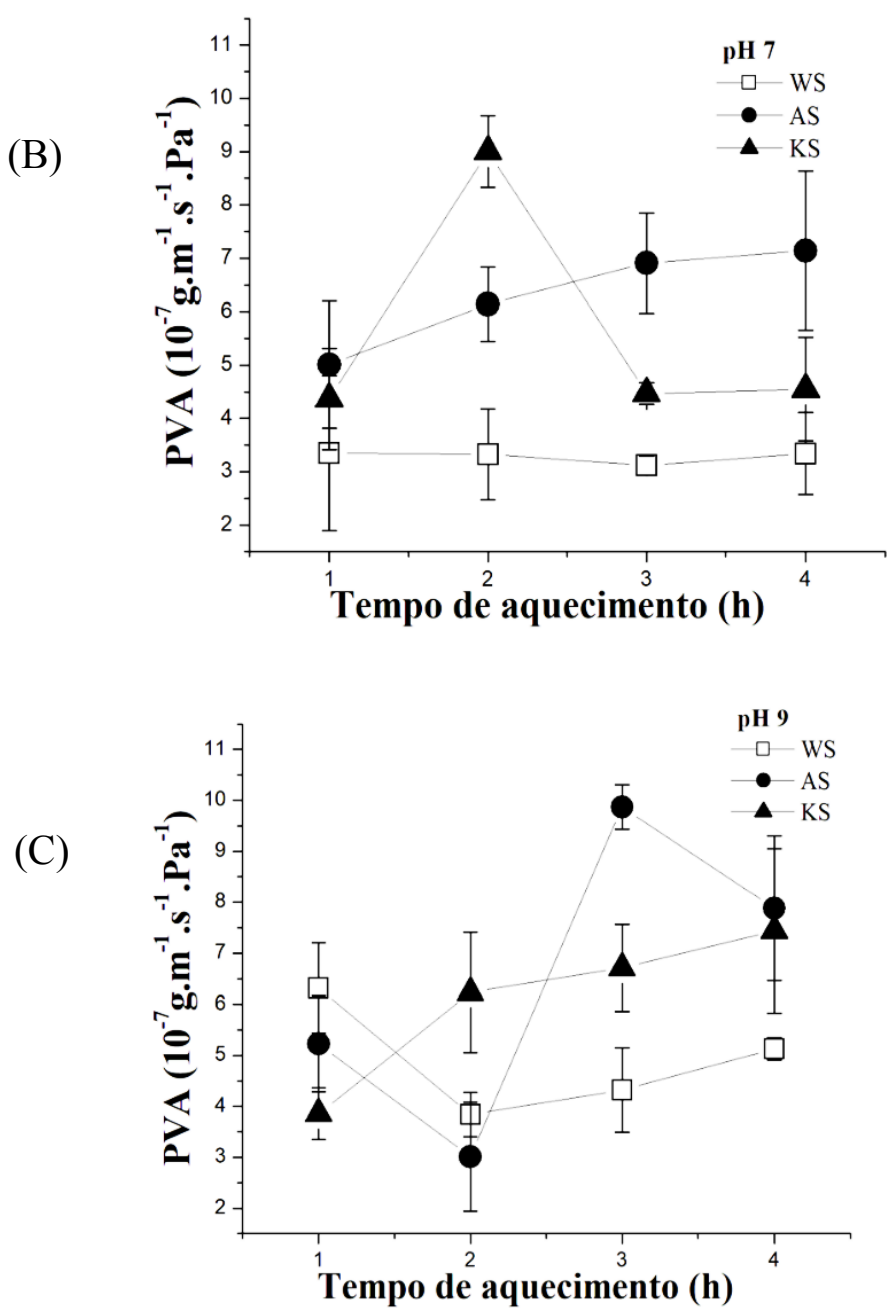
Dos filmes analisados anteriormente, concluiu-se que as melhores condições para elaboração foram: $\mathrm{pH} 5$, tempo de aquecimento de $2 \mathrm{~h}$ para todos os três amidos (WS, AS, KS). Os filmes elaborados nas melhores condições foram produzidos e caracterizados em propriedades funcionais e mecânicas.

\subsubsection{Caracterização dos filmes de farinha de urucum na formulação escolhida}

\subsubsection{Propriedades mecânicas dos filmes}

A Tabela 3.5 apresenta a espessura e as propriedades mecânicas (tensão, elongação e módulo de Young) dos filmes de farinha de urucum (WS, AS e KS) produzidos em pH 5 e tempo de aquecimento de $2 \mathrm{~h}$.

Tabela 3.5 - Espessura e propriedades mecânicas dos filmes elaborados com diferentes farinhas de urucum

\begin{tabular}{ccccc}
\hline Filme & $\begin{array}{c}\text { Espessura } \\
(\boldsymbol{\mu m})\end{array}$ & $\begin{array}{c}\text { Tensão } \\
(\mathbf{M P a})\end{array}$ & $\begin{array}{c}\text { Elongação } \\
(\mathbf{\%})\end{array}$ & $\begin{array}{c}\text { Módulo de Young } \\
(\mathbf{M p a})\end{array}$ \\
\hline $\mathbf{W S}$ & $88,08 \pm 8,08^{\mathrm{a}}$ & $0,39 \pm 0,07^{\mathrm{b}}$ & $17,16 \pm 0,29^{\mathrm{a}}$ & $8,31 \pm 1,39^{\mathrm{b}}$ \\
$\mathbf{A S}$ & $90,83 \pm 10,60^{\mathrm{a}}$ & $0,17 \pm 0,03^{\mathrm{c}}$ & $16,90 \pm 0,65^{\mathrm{a}}$ & $3,50 \pm 0,71^{\mathrm{c}}$ \\
$\mathbf{K S}$ & $85,26 \pm 5,91^{\mathrm{a}}$ & $1,08 \pm 0,23^{\mathrm{a}}$ & $13,63 \pm 2,25^{\mathrm{b}}$ & $24,03 \pm 5,70^{\mathrm{a}}$
\end{tabular}

a,b,c: letras diferentes em uma mesma colunas indicam diferença significativa entre os filmes de amidos obtidos por diferentes métodos de extração, de acordo com o teste de Tukey $(\mathrm{p}<$ $0,05)$.

Ao analisar a Tabela 3.5, nota-se que as espessuras dos filmes da farinha de urucum WS, AS e KS não apresentaram diferença significativa, segundo o teste de Tukey $(p<0,05)$. Entretanto, os valores de tensão, elongação e módulo de Young dos filmes de farinha WS, AS e KS apresentaram diferença significativa, sendo os filmes de farinha KS os mais resistentes mecanicamente e mais rígidos, mas menos elongáveis quando comparados aos filmes produzidos com as farinhas WS e AS. O maior conteúdo de amilose e maior teor de amido da farinha KS, resultou na formação de uma matriz mais coesa, com mais interações presentes entre os polímeros de amido (amilose-amilose, amilose-amilopectina, amilopectinaamilopectina). Este comportamento está de acordo com o descrito na literatura, já que se espera que amidos com alto teor de amilose formem filmes com alta resistência mecânica devido à linearidade das cadeias de amilose (MALI; GROSSMANN; YAMASHITA, 2010; PELISSARI et al., 2012). 
Já os filmes de farinha WS e AS apresentaram menores valores de tensão e módulo de Young, e maiores valores de elongação. De acordo com a composição química, WS e AS são farinhas com menor grau de pureza em amido. A presença de maior teor de fibras comoocorre na farinha WS e de lipídeos como ocorre na farinha AS podem interferir na gelatinização dos grânulos de amido dificultando a formação das interações: amilose-amilose, amiloseamilopectina, amilopectina-amilopectina durante a formação da matriz filmogênica tornando o filme mais frágil (PELISSARI et al., 2012). A maior elongação é justificada pela presença de proteínas e/ou lípideos e o teor de amilopectina na matriz, o quais podem formar matrizes mais flexíveis devido às interações fortes de ligação de hidrogênio entre o amido e proteínas (GUTIÉRREZ et al., 2016). Além disso, os lipídeos podem atuar como plastificante. Portanto, os filmes de farinhas WS e AS apresentaram-se menos resistentes, menos rígidos e mais flexíveis.

O mesmo comportamento foi observado por Batista; Tanada-Palmu; Grosso, (2005) que ao trabalharem com filmes a base de pectina adicionada de ácidos graxos observaram que ao se triplicar as doses de material lipídico a resistência mecânica à tração diminuiu 9,81\%. Segundo Chen (1995), ao trabalhar com filmes formados a partir de proteínas do leite e lipídios, percebeu que à medida que se adiciona este último em doses crescentes à resistência mecânica à tração decresce linearmente e atribuiu o fenômeno à dispersão e inserção do lipídio como plastificante na matriz protéica que modificou sua organização. Yang; Paulson (2000) no experimento de filmes formados a partir de proteína gelana plastificado com uma mistura dos ácidos graxos palmítico e esteárico, notaram que à medida que o teor de lipídeo era adicionado à formulação a resistência mecânica à tração aumentava e atribuíram o acontecimento pela possível troca do polímero gelana pelos dois ácidos graxos na matriz formadora do filme, em resposta à diferença de polaridade entre o componente lipídico e o protéico. Tapia-Blácido; Sobral \& Menegalli (2005) elaboraram filmes de farinha de amaranto de alta flexibilidade e baixa resistência mecânica. Andrade-Mahecha; Tapia-Blácido \& Menegalli (2009) produziram filmes de farinha de achira e obtiveram materiais com boas propriedades mecânicas. Pelissari et al. (2013) produziram filmes de amido e de farinha de banana verificando que os filmes de farinha de banana foram menos resistentes e mais elongáveis. Maniglia et al. (2014, 2015a) produziram filmes de farinha de cúrcuma de alta resistência. Daudt et al. (2016) produziram filmes de amido e de farinha de pinhão. Os filmes de farinha apresentaram menor rigidez, tensão e elongação. De modo geral, os filmes de farinhas de urucum WS, AS e KS apresentaram flexibilidade e 
pouca resistência e rigidez. A Tabela 3.6 apresenta resultados de propriedades mecânicas de filmes relatados na literatura que foram produzidos com polímeros de diferentes fontes.

Tabela 3.6 - Comparação das propriedades mecânicas de filmes elaborados com polímeros de diferentes fontes

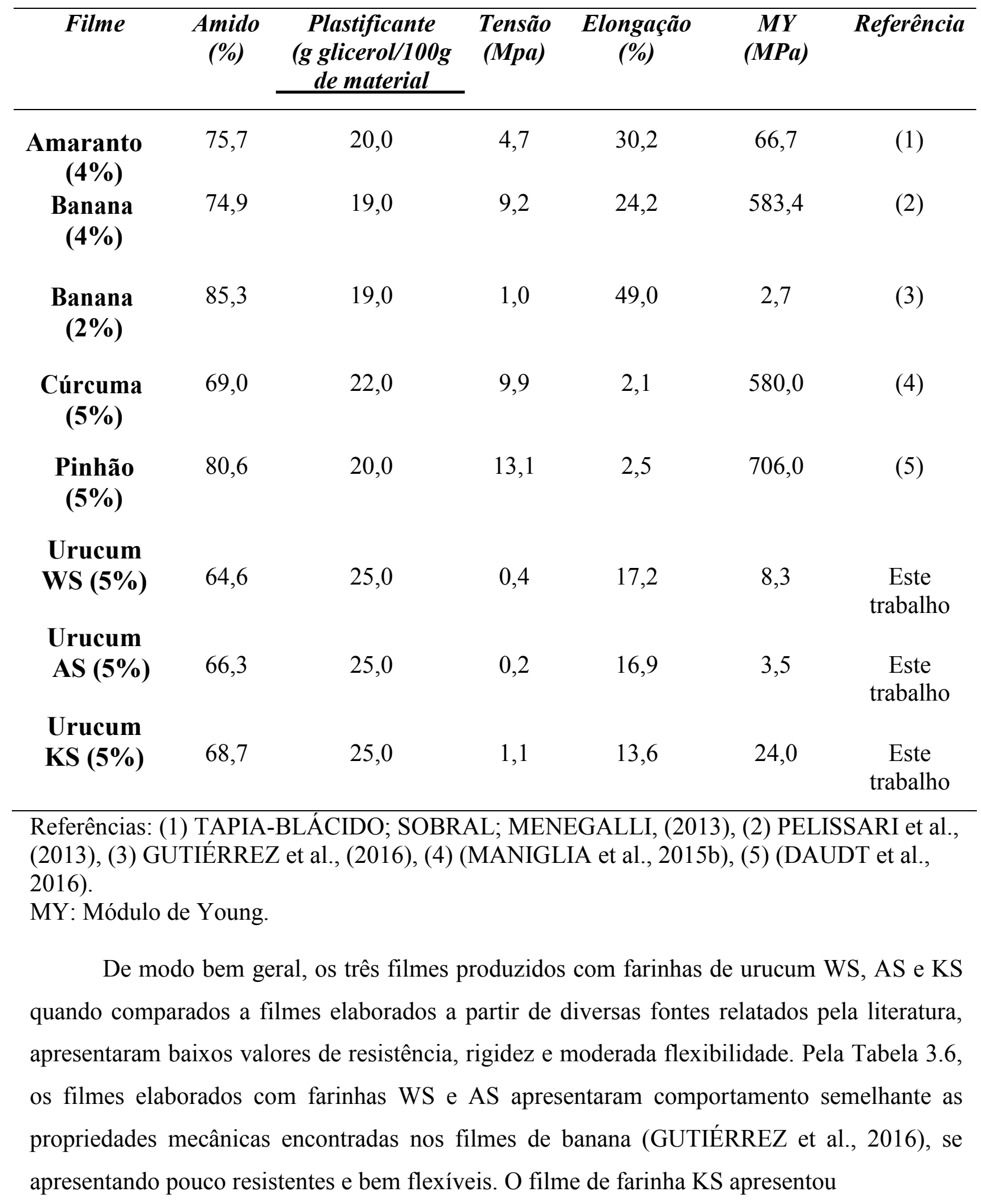


comportamento semelhante ao filme de amaranto, se apresentando mais resistente e menos flexível.

Como apresentado na Tabela 3.6, o teor de amido presente nas diferentes fontes vegetais é próximo, o plastificante utilizado foi o mesmo, glicerol, em concentrações próximas. No entanto, nota-se que a diferença nas propriedades mecânicas apresentadas pelos filmes pode ter ocorrido devido o tipo e a quantidade dos demais componentes presentes nestes materiais (por exemplo, fibras, lipídeos e proteínas), a proporção de amilose-amilopectina dos amidos e a morfologia dos materiais.

\subsubsection{Propriedades funcionais}

A Tabela 3.7 apresenta as propriedades funcionais (umidade, solubilidade, permeabilidade ao vapor de água e ângulo de contato) dos filmes de farinha de urucum (WS, AS e KS).

Tabela 3.7 - Propriedades funcionais dos filmes elaborados com diferentes farinhas de urucum

\begin{tabular}{ccccc}
\hline Filme & $\begin{array}{c}\text { Umidade } \\
\mathbf{( \% )}\end{array}$ & $\begin{array}{c}\text { Solubilidade } \\
\mathbf{( \% )}\end{array}$ & $\begin{array}{c}\text { PVA } \\
\left(\mathbf{( 1 0}^{-\mathbf{7}} \cdot \mathbf{g} \cdot \mathbf{m}^{-\mathbf{1}} \cdot \mathbf{s}^{-\mathbf{1}} \cdot \mathbf{P a} \mathbf{A}^{-\mathbf{1}}\right)\end{array}$ & Ângulo de contato $\left(^{\circ}\right)$ \\
\hline WS & $27,72 \pm 1,64^{\mathrm{a}}$ & $48,39 \pm 2,15^{\mathrm{b}}$ & $2,18 \pm 0,17^{\mathrm{b}}$ & $40 \pm 5^{\mathrm{c}}$ \\
AS & $23,50 \pm 1,19^{\mathrm{b}}$ & $61,52 \pm 1,29^{\mathrm{a}}$ & $2,11 \pm 0,34^{\mathrm{b}}$ & $56 \pm 5^{\mathrm{b}}$ \\
KS & $17,26 \pm 0,67^{\mathrm{c}}$ & $43,59 \pm 1,48^{\mathrm{c}}$ & $2,46 \pm 0,08^{\mathrm{a}}$ & $90 \pm 2^{\mathrm{a}}$
\end{tabular}

* PVA: permeabilidade de vapor de água.

a,b,c: letras diferentes em uma mesma coluna indicam diferença significativa entre os filmes de farinhas WS, AS e KS, de acordo com o teste de Tukey $(p<0,05)$.

Os filmes de farinhas de urucum WS e AS apresentaram ângulos de contato $(\theta)$ menores que $90^{\circ}$, característico de superfícies hidrofílicas (BICO; MARZOLIN; QUÉRÉ, 1999). Já o filme de farinha de urucum KS apresentou ângulo de contato $(\theta)$ por volta de $90^{\circ}$, típico de superfícies hidrofóbicas.

Os filmes de farinha WS e AS apresentaram maiores valores de umidade esolubilidade e menores valores de ângulo de contato que o filme de farinha KS (Tabela 3.7). Estes resultados indicam que os filmes de farinhas WS e AS são mais hidrofílicos quando comparados ao filme de farinha KS considerado hidrofóbico. A maior hidrofilicidade dos filmes WS e AS 
influenciou também nas suas propriedades mecânicas, pois exerceu efeito plastificante aumentando sua elongação e diminuindo sua resistência mecânica (DELVILLE, 2002; GODBILLOT et al., 2006; PELISSARI et al., 2013; SOBRAL, 2001).

O filme de farinha AS apresentou maior solubilidade em relação aos filmes de farinha WS e KS. A farinha AS tem menor teor de fibras, enquanto as farinhas WS e KS são ricas em fibras. Logo, nos filmes de farinhas WS e KS há maiores interações entre amido-fibra, fibralipídeo e fibra-proteína presentes na matriz do filme, aumentando a sua hidrofobicidade, diminuindo a sua afinidade com a água (TAPIA-BLÁCIDO et al., 2007). As solubilidades dos filmes de farinha de urucum foram altas quando comparadas à solubilidade de filmes de cúrcuma (38\%) (MANIGLIA et al., 2014). Pode-se dizer que os filmes de farinha KS e WS apresentaram solubilidade intemediária. Filmes com valores elevados de solubilidade em água poderiam ter aplicação como veículo de bioativação de substâncias, uma vez que se dissolvem facilmente na boca (SOTHORNVIT; KROCHTA, 2000).

Em relação ao PVA, os filmes de farinhas WS e AS foram menos permeáveis ao vapor de água quando comparado ao filme de farinha KS. A menor permeabilidade do filme de farinha WS pode estar associada a maior presença de fibras presentes nesta farinha. Neste caso, as fibras criam uma espécie de labirinto de preenchimento nesta matriz, evitando a difusão de vapor de água através da matriz e diminuindo o PVA (GARCÍA et al., 2009; MA et al., 2008). E a menor permeabilidade do filme de farinha AS pode estar associada ao maior teor de lipídeo nesta farinha. Neste caso, o lipídeo atua como uma barreira, preenchendo os poros e impedindo a passagem de água (GARCIA; MARTINO; ZARITZKY, 2000).

Os resultados de permeabilidade ao vapor de água obtidos neste trabalho são altos quando comparados a filmes produzidos por Tapia-Blácido; Do Amaral Sobral \& Menegalli, (2011) a partir de farinha de amaranto com PVA de 7,0 x $10^{-11} \mathrm{~g} \cdot \mathrm{m}^{-1} \cdot \mathrm{s}^{-1} \cdot \mathrm{Pa}^{-1}$, filmes de farinha de banana com valores de PVA de 2,1 x $10^{-10} \mathrm{~g} \cdot \mathrm{m}^{-1} \cdot \mathrm{s}^{-1} \cdot \mathrm{Pa}^{-1}$ (PELISSARI et al., 2013), filmes de farinha de canhihua com valor de PVA 1,20 x 10 $0^{-10}$ g.m ${ }^{-1} \cdot \mathrm{s}^{-1} \cdot \mathrm{Pa}^{-1}$ (SALAS-VALERO; TAPIA- BLÁCIDO; MENEGALLI, 2014), filmes de farinha de pinhão com valor de 5,25 x $10^{-10} \mathrm{~g} \cdot \mathrm{m}^{-1} \cdot \mathrm{s}^{-1} \cdot \mathrm{Pa}^{-1}$ (DAUDT et al., 2016). Maniglia et al. (2014) produziram filme de farinha de cúrcuma com PVA de $9,80 \times 10^{-11} \mathrm{~g} \cdot \mathrm{m}^{-1} \cdot \mathrm{s}^{-1} \cdot \mathrm{Pa}^{-1}$.

\subsubsection{Capacidade de absorção de água dos filmes}

A Figura 3.11 apresenta a capacidade de absorção de água dos filmes elaborados com 
farinhas de urucum isoladas pelos métodos WS, AS e KS plastificados com glicerol.

Figura 3.11 - Capacidade de absorção de água dos filmes elaborados com diferentes farinhas de urucum (WS, AS, KS)

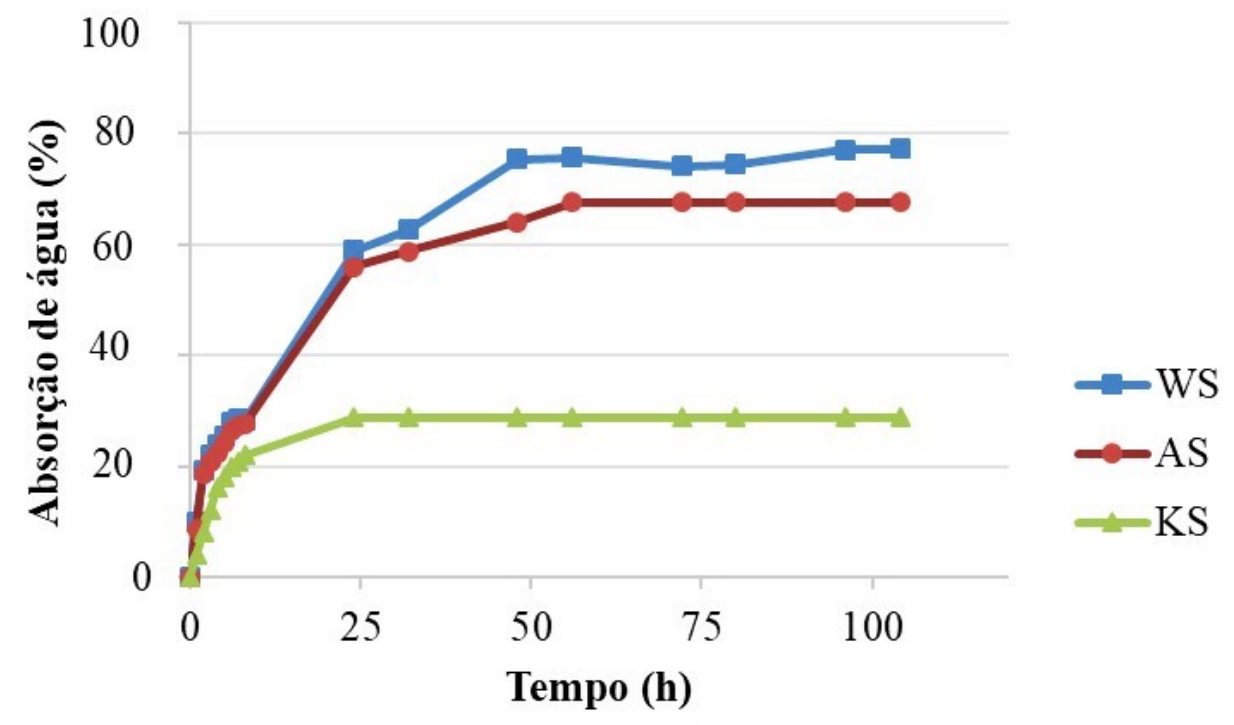

Ao analisar a Figura 3.11 pode-se observar que as curvas de absorção de água dos filmes de farinha de urucum apresentaram comportamento semelhante: houve rápida absorção de água até $24 \mathrm{~h}$, seguido por menor absorção até que permanece constante a $120 \mathrm{~h}$. Os filmes de farinhas WS e AS apresentaram maior capacidade de absorção de água, 78\%, 69\%, respectivamente quando comparado a capacidade de absorção de água do filme de farinha KS, $25 \%$. Os valores de absorção de água dos filmes de farinhas de urucum WS e AS foram maiores que os resultados de absorção de água em filmes de farinha de cúrcuma, 45,4\%, sendo apenas os filmes de farinha de urucum KS de menor capacidade de absorção quando comparados aos filmes de farinha de cúrcuma (MANIGLIA et al., 2014). A maior capacidade de absorção de água dos filmes de farinhas WS e AS renderam filmes mais solúveis, como pode ser observado na Tabela 3.7.

A capacidade de absorção de água geralmente concorda com o comportamento da solubilidade em água, umidade e molhabilidade dos filmes (CONDÉS; AÑÓN; MAURI, 2013). Os filmes de farinha de urucum mais úmidos, mais solúveis e mais hidrofílicos são também os que apresentaram maior capacidade de absorção de água. A menor capacidade de absorção de água dos filmes de farinha de urucum KS indica que estes filmes são menos hidrofílicos do que os filmes de farinhas de urucum WS e AS. As farinhas de urucum WS e AS como já mencionado, se apresentam como um material menos puro, com maior proporção de proteínas e fibras que a farinha de urucum $\mathrm{KS}$, e esta composição resultou em filmes com maior 
capacidade de absorção de água (mais higroscópicos) do que os filmes de farinha KS. As farinhas WS e AS apresentaram teor de amilose inferior ao teor de amilose na farinha KS, logo as farinhas WS e AS contêm mais amilopectina. O maior teor de amilopectina contribui para uma maior afinidade com a água (Li et al., 2008). Pela mesma razão, os filmes de farinha KS apresentaram capacidade de absorção de água menor do que os filmes de farinha WS e AS, pois a matriz de amido KS apresenta o maior teor de amilose dentre as farinhas. Em geral, os filmes de farinha de urucum produzidos neste estudo apresentaram elevada capacidade de absorção de água (69 a 78\%), com exceção do filme de farinha KS (25\%). Filmes com alta absorção de água não são indicados para uso como embalagem de alimentos que têm elevada atividade de água (MALI; GROSSMANN; YAMASHITA, 2010).

\subsection{Conclusão}

As farinhas de urucum obtidas a partir do resíduo de urucum por moagem em meio neutro (WS), meio ácido (AS) e meio alcalino (KS) tem potencial para formação de filmes biodegradáveis. As diferenças no teor de amido, amilose, fibra, proteínas e lipídeos das farinhas WS, AS e KS causou também diferenças nas propriedades mecânicas e funcionais dos filmes de farinha de urucum, assim como o pH e tempo de aquecimento utilizado para a produção destes filmes. De acordo com os resultados do planejamento, as melhores condições para elaboração de filmes de farinha de urucum com melhores propriedades mecânicas e funcionais são pH 5 e 2 horas de aquecimento quando utilizado a farinha KS. Nestas condições de pH e tempo de aquecimento verificou-se que os filmes de farinha KS foram menos hidrofílicos com menor capacidade de absorção de umidade, menos solúveis, mais permeáveis ao vapor de água e mais resistentes mecanicamente quando comparados aos filmes WS e AS. O maior teor de amido e amilose na farinha KS permitiram obter filmes KS com melhores propriedades mecânicas. O pH ácido (5) favoreceu a formação de interações amido-proteína, proteínaproteína, amido-fibra, promovendo a formação de uma matriz coesa.

\subsection{Referências Bibliográficas}

ALTING, A. C. et al. Formation of Disulfide Bonds in Acid-Induced Gels of Preheated Whey Protein Isolate. Journal of Agricultural and Food Chemistry, v. 48, p. 5001-5007, 2000. 
ALTINGA, A. C. et al. Number of thiol groups rather than the size of the aggregates determines the hardness of cold set whey protein gels. Food Hydrocolloids, v. 17, p. 469-479, 2003.

ANDRADE-MAHECHA, M. M.; TAPIA-BLÁCIDO, D. R.; MENEGALLI, F. C. Development and optimization of biodegradable films based on achira flour. Carbohydrate Polymers, v. 88, n. 2, p. 449-458, abr. 2009.

AOAC, A. OF O. A. C. Official Methods of Analysis of AOAC International. 15. ed. Gaithersburg: AOAC International, 1995.

ASTM. ASTM STANDARD E 96 -95. Standard test method for water vapor transmission of materials. In: Annual book of ASTM Standards. Philadelphia: ., 1995.

ASTM. ASTM STANDARD D644-99. Standard test methods for moisture content of paper and paperboard by oven drying. In: Annual book of ASTM Standards. American Society fo Testing and Materials. Philadelphia: ., 1999.

ASTM. D882-09 Standard test method for tensile properties of thin plastic sheeting. In: Annual book of ASTM Standards. Annual boo ed. West Conshohocken: ., 2002.

BATISTA, J. A.; TANADA-PALMU, P. S.; GROSSO, C. R. F. Efeito da adição de ácidos graxos em filmes à base de pectina. Ciência e Tecnologia de Alimentos, v. 25, n. 4, p. 781788, dez. 2005.

BEMILLER, J. N. Starch-based gums. In: WHISTLER, R. L.; BEMILLER, J. N. (Eds.). . Industrial gums. USA: Academic Press, 1993. p. 579-600.

BICO, J.; MARZOLIN, C.; QUÉRÉ, D. Pearl drops. A Letters Journal Exploring the Frontiers of Physics, v. 47, n. 2, 1999.

CHEN, H. Functional Properties and Applications of Edible Films Made of Milk Proteins. Journal of Dairy Science, v. 78, n. 11, p. 2563-2583, nov. 1995.

CONDÉS, M. C.; AÑÓN, M. C.; MAURI, A. N. Amaranth protein films from thermally treated proteins. Journal of Food Engineering, v. 119, n. 3, p. 573-579, 2013.

DAMODARAM, S. Aminoacids, peptides and proteins. In: Food Chemistry. 3. ed. New York: Marcel Dekker: [s.n.]. p. 321-429.

DAMODARAN, P. \& F. Qímica de Alimentos de fennema. [s.1.] Artmed, 2010.

DAUDT, R. M. et al. Comparative study on properties of edible films based on pinh?o ( Araucaria angustifolia ) starch and flour. Food Hydrocolloids, v. 60, p. 279-287, out. 2016.

DELVILLE, J. Solid state photocrosslinked starch based films: a new family of homogeneous modified starches. Carbohydrate Polymers, v. 49, n. 1, p. 71-81, 1 jul. 2002.

DUFRESNE, A.; DUPEYRE, D.; VIGNON, M. R. Cellulose microfibrils from potato tuber cells: processing and characterization of starch-cellulose microfibril composites. Journal of Applied Polymer Science, v. 76, n. 14, p. 2080-2092, 2000.

FAIRLEY, P. et al. Mechanical Properties and Water Vapor Permeability of Edible Films from Whey Protein Isolate and N-Ethylmaleimide or Cysteine. Journal of Agricultural and Food Chemistry, v. 44, n. 12, p. 3789-3792, 1996.

FERREIRA, A. H. Efeito da adição de surfactantes e do ajuste de pH sobre filmes a base de gelatina, triacetina, ácidos graxos e cera de carnaúba e de cana-de-açúcar. Dissertaçã 
ed. Campinas: ., 2006.

GARCÍA, M. A. et al. Electrically treated composite FILMS based on chitosan and methylcellulose blends. Food Hydrocolloids, v. 23, n. 3, p. 722-728, maio 2009.

GARCIA, M. A.; MARTINO, M. N.; ZARITZKY, N. E. Lipid Addition to Improve Barrier Properties of Edible Starch-based Films and Coatings. Journal of Food Science, v. 65, n. 6, p. 941-944, set. 2000.

GENNADIOS, A. . et al. Edible coating and films based on proteins. In: Technomic Publishing Company. In: KROCHT ed. N.Y, USA: [s.n.]. p. 201-277.

GODBILLOT, L. et al. Analysis of water binding in starch plasticized films. Food Chemistry, v. 96, n. 3, p. 380-386, jun. 2006.

GONTARD, N.; GUILBERT, S. Bio-packaging: technology and properties of edible and/or biodegradable material of agricultural origin. In: Food Packaging and Preservation. Boston, MA: Springer US, 1994. p. 159-181.

GONTARD, N.; GUILBERT, S.; CUQ, J.-L. Edible Wheat Gluten Films: Influence of the Main Process Variables on Film Properties using Response Surface Methodology. Journal of Food Science, v. 57, n. 1, p. 190-195, jan. 1992.

GUTIÉRREZ, T. J. et al. Effect of beet flour on films made from biological macromolecules: Native and modified plantain flour. International Journal of Biological Macromolecules, v. 82, p. 395-403, jan. 2016.

LI, Y. ET AL. Paste viscosity of rice starches of different amylose content and carboxymethylcellulose formed by dry heating and the physical properties of their films. Food Chemistry, v. 109, n. 3, p. 616-623, 2008.

MA, X. et al. Fabrication and Characterization of Citric Acid-Modified Starch Nanoparticles/Plasticized-Starch Composites. Biomacromolecules, v. 9, n. 11, p. 3314-3320, 10 nov. 2008.

MALI, S.; GROSSMANN, E. M. V.; YAMASHITA, F. Filmes de amido: produção, propriedades e potencial de utilização. Ciências Agrárias, Londrina, v. v. 31, p. 137-156, 2010.

MANIGLIA, B. C. et al. Development of bioactive edible film from turmeric dye solvent extraction residue. LWT - Food Science and Technology, v. 56, n. 2, p. 269-277, maio 2014.

MANIGLIA, B. C. et al. Turmeric dye extraction residue for use in bioactive film production: Optimization of turmeric film plasticized with glycerol. LWT - Food Science and Technology, v. 64 , n. 2, p. 1187-1195, dez. 2015a.

MANIGLIA, B. C. et al. Turmeric dye extraction residue for use in bioactive film production: Optimization of turmeric film plasticized with glycerol. LWT - Food Science and Technology, v. 64 , n. 2, p. 1187-1195, dez. 2015b.

PELISSARI, F. M. et al. Isolation and characterization of the flour and starch of plantain bananas ( Musa paradisiaca ). Starch - Stärke, v. 64, n. 5, p. 382-391, maio 2012.

PELISSARI, F. M. et al. Optimization of process conditions for the production of films based on the flour from plantain bananas (Musa paradisiaca). LWT - Food Science and Technology, v. 52, n. 1, p. 1-11, jun. 2013. 
RIBEIRO, E. .; SERAVALLI, E. A. G. Química de Alimentos. 1. ed. São Paulo: Instituto Mauá de Tecnologia, 2004.

SALAS-VALERO, L. M.; TAPIA-BLACIDO, D. R.; MENEGALLI, F. C. BIOFILMS BASED ON CANIHUA FLOUR (Chenopodium Pallidicaule): DESIGN AND CHARACTERIZATION. Química Nova, 2014.

SGARBIERI, V. Proteínas em Alimentos Protéicos: Propriedades, degradação e modificação. Ed. Varela ed. São Paulo: Varela, 1996.

SOARES, D. S. B. Influência do pH e da irradiação em filmes biodegradáveis de proteínas do soro de leite. Goiás: UNIVERSIDADE FEDERAL DE GOIÁS, 2012a.

SOARES, D. S. B. Influência do pH e da irradiação em filmes biodegradáveis de proteínas do soro de leite. Goiânia: UNIVERSIDADE FEDERAL DE GOIÁS, 2012 b.

SOBRAL, P. J. A. Mechanical, water vapor barrier and thermal properties of gelatin based edible films. Food Hydrocolloids, v. 15, p. 423-432, 2001.

SOTHORNVIT, R.; KROCHTA, J. M. Plasticizer Effect on Oxygen Permeability of?Lactoglobulin Films. Journal of Agricultural and Food Chemistry, v. 48, n. 12, p. 62986302, dez. 2000.

SUN, J. X. et al. Isolation and characterization of cellulose from sugarcane bagasse. Polymer Degradation and Stability, v. 84, n. 2, p. 331-339, maio 2004.

TAPIA-BLÁCIDO, D. et al. Contribution of the Starch, Protein, and Lipid Fractions to the Physical, Thermal, and Structural Properties of Amaranth (Amaranthus caudatus) Flour Films. Journal of Food Science, v. 72, n. 5, p. E293-E300, jun. 2007.

TAPIA-BLÁCIDO, D. R.; DO AMARAL SOBRAL, P. J.; MENEGALLI, F. C. Optimization of amaranth flour films plasticized with glycerol and sorbitol by multi-response analysis. LWT - Food Science and Technology, v. 44, n. 8, p. 1731-1738, out. 2011.

TAPIA-BLÁCIDO, D. R.; SOBRAL, P. J. DO A.; MENEGALLI, F. C. Effect of drying conditions and plasticizer type on some physical and mechanical properties of amaranth flour films. LWT - Food Science and Technology, v. 50, n. 2, p. 392-400, mar. 2013.

TAPIA-BLÁCIDO, D.; SOBRAL, P. J.; MENEGALLI, F.

C. Development and characterization of biofilms based on Amaranth flour (Amaranthus caudatus). Journal of Food Engineering, v. 67, n. 1-2, p. 215-223, mar. 2005.

VALÉRIO, M. A. et al. Annatto seed residue (Bixa orellana L.): nutritional quality. Food Science and Technology (Campinas), v. 35, n. 2, p. 326-330, jun. 2015.

YANG, L.; PAULSON, A. . Effects of lipids on mechanical and moisture barrier properties of edible gellan film. Food Research International, v. 33, n. 7, p. 571-578, ago. 2000.

YOSHIDA, C. M. P. Aplicação de concentrado proteico de soro de leite bovino na elaboração de filmes comestiveis. Campinas: UNICAMP, 2002 
Capítulo 4. PROPRIEDADES BIOATIVAS E ATIVIDADE ANTIMICROBIANA 


\section{Apresentação}

Este capítulo aborda a determinação de compostos ativos, como fenólicos, carotenoides, teor de bixina e atividade antioxidante dos filmes de farinha de urucum WS, AS, e KS, elaborados em pH 5 em 2 horas de aquecimento. Foram avaliadas a atividade antimicrobiana do extrato das sementes de urucum, do extrato do rizoma de cúrcuma e dos filmes de farinha de urucum WS, AS e KS, contra bactérias, fungos filamentosos e levedura através do teste do halo de inibição ou método da difusão em ágar. O extrato das sementes de urucum apresentou eficiência antimicrobiana contra Sthapylococcus aureus, Sthapylococcus uberis e Sthapylococcus agalactiae, além de redução da esporulação dos fungos Aspergillus fumigatus e Mucor sp. O extrato do rizoma de cúrcuma apresentou eficiência antimicrobiana contra Sthapylococcus aureus, Sthapylococcus uberis, Sthapylococcus agalactiae e Candida albicans, além de redução na esporulação de fungos Aspergillus tamarri, Aspergillus flavus, Fusarium oxysporum e Penicillium expansum. Já para os filmes, apenas o filme elaborado com farinha KS apresentou um bom efeito contra Sthapylococcus aureus, Sthapylococcus uberis, Escherichia coli, Pseudomonas aeruginosa, Listeria monocytogenes e levedura Candida albicans.

\subsection{Materiais e métodos}

\subsubsection{Materiais}

Os frutos da Bixa orellana, o urucum, foram colhidos no jardim da Câmara Municipal de Ribeirão Preto-SP.

Os rizomas de Cúrcuma Longa L, foram fornecidos secos pela empresa Flores e Ervas (Campinas - SP, Brasil).

Os solventes Etanol P.A., Isopropanol P.A., o radical ABTS (2,2'-azinobis (3etilbenzoatiazolina-6-ácido sulfônico)), o antioxidante sintético BHT (2,6-Di-tert-butyl-4methylphenol), o antioxidante sintético Trolox ((+)-6-Hydroxy-2,5,7,8-tetramethylchromane2-carboxylic acid) e o padrão bixina (95\%) foram adquiridos da Sigma-Aldrich, (São Paulo, Brasil).

Os filmes de urucum foram elaborados pelo processo casting, como descrito no capítulo 3, item 3.1.2, a partir das farinhas isoladas do resíduo da extração de corante de urucum 
fornecido pela empresa de corantes "Firace" (São Paulo, Brasil), por moagem em água (WS), moagem em $\mathrm{pH}$ ácido (AS) e moagem em $\mathrm{pH}$ alcalino (KS), conforme descrito no capítulo 2, item 2.1.2.

Os meios de cultura Tryptone Soya Agar (TSA CMO131) e Potato Dextrose Agar (BDA CMO139), ambos da marca OXOID foram adquiridos da empresa J.C.N.C Hospitalar \& Lab (Ribeirão Preto - SP, Brasil). Os discos brancos estéreis $(901945,6 \mathrm{~mm} \varnothing)$ foram adquiridos da Laborclin (São Paulo, Brasil).

O filme de amido de mandioca (5\% amido/100g; 20\% glicerol $/ 5 \mathrm{~g}$ de amido), utilizado como controle negativo, foi produzido pelo método casting.

Foram realizados ensaios com as bactérias Staphylococcus aureus (ATCC 6538), Escherichia coli (ATCC 10536), Pseudomonas aeruginosa (ATCC 9027), Listeria monocytogenes (ATCC 19115) e levedura Candida albicans (ATCC 11006). As bactérias Staphylococcus uberis e Staphylococcus agalactiae fazem parte da coleção do professor Dr. Luiz Alberto Beraldo de Moraes, do Departamento de Química da FFCL-RP. Foram feitos ensaios com os fungos CFF 118 Aspergillus tamarri, CFF 25 Aspergillus flavus, CFF 04 Aspergillus fumigatus, CFF 163 Mucor sp, CFF 39 Fusarium oxysporum, CFF 128 Penicillium

expansum, pertencentes à coleção de Fungos Filamentosos (CFF) do Laboratório de

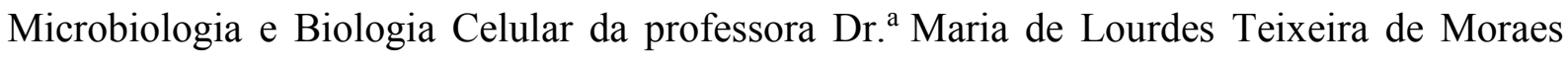
Polizeli, do Departamento de Biologia da FFCL-RP.

\subsubsection{Determinação dos compostos ativos}

\subsubsection{Carotenoides totais e teor de bixina}

A determinação do teor de carotenoides totais dos filmes foi realizada de acordo com o método descrito por Gross (1991). Assim, 0,1g de amostra de filme foram adicionados a $2 \mathrm{~mL}$ de solução contendo $200 \mathrm{mg} . \mathrm{L}^{-1}$ de hidroxitolueno butilado (BHT) em solvente acetona-etanol (1:1) e manteve-se sob vigorosa agitação, durante 1 hora. Em seguida, a amostra foi filtrada em papel filtro (filtro 0,45 $\mu \mathrm{m}$ Millipore, Brasil), e foram feitas sucessivas lavagens utilizando a solução de acetona:etanol (1:1). O filtrado foi diluído até atingir $10 \mathrm{~mL}$ (Vf) de extrato, em balão volumétrico. A absorvância do extrato foi medida na região de UV-visível em um espectrofotômetro (UV-M51 UV- Visível, Bel, Brasil), a 470nm. O solvente puro foi utilizado 
como branco. O teor de carotenoides totais foi calculado de acordo com a equação 1 e foi expresso em $\mu \mathrm{g}$ de carotenoides por g de amostra seca.

$$
\mathrm{CT}(\mu \mathrm{g} \text { carotenoides } / \mathrm{g} \text { amostra })=\frac{A x V_{f} \times 106}{M \times 100 \times A_{\mathrm{cm}}^{1 \%}}
$$

Sendo: CT: teor de carotenoides totais como $\mu \mathrm{g}$ equivalente em $\beta$-carotenos por cada $\mathrm{g}$ de amostra seca, A: absorvância $(\lambda=470 \mathrm{~nm}), \mathrm{V}_{\mathrm{f}}$ : volume total da solução $(\mathrm{mL}), A_{c m}^{1 \%}=2500$ corresponde ao coeficiente de absorvância específica para $\beta$-carotenos, $\mathrm{M}$ é a massa da amostra (g).

O teor de bixina, carotenoide principal presente nos filmes de urucum, foi determinado por HPLC (CTO-10ASVP, Shimadzu, Japão). Aproximadamente $200 \mathrm{mg}$ de amostras de filme de urucum foram pesadas, seguido pela adição de $2 \mathrm{~mL}$ de metanol. A mistura foi agitada à temperatura ambiente $\left(\sim 25^{\circ} \mathrm{C}\right)$ durante $3 \mathrm{~h}$, na ausência de luz. A amostra foi filtrada em papel filtro (filtro 0,45 $\mu \mathrm{m}$ Millipore, Brasil) para obter o extrato. Em seguida, $50 \mu \mathrm{L}$ do extrato foram injetados nas seguintes condições: coluna C-18 (Luna da Phenomenex, 4,6 x 150 mm, 5 um, EUA), conjunto de detectores de diodo (SPD M10AVP, Shimadzu, EUA) (460 nm), loop = 20 $\mu \mathrm{L}$, fluxo $=1,0 \mathrm{~mL} \cdot \mathrm{min}^{-1}$. A fase móvel utilizada foi acetonitrila:ácido acético a $2 \%(65: 35)$. As soluções padrão de bixina em metanol foram preparadas em diferentes concentrações $(0,17$ a 3,20 mg. $\mathrm{L}^{-1}$ ) para construir a curva de calibração. A curva de calibração foi estabelecida através da representação gráfica das áreas de pico em função da concentração de cada analito. A análise foi feita em triplicata.

\subsubsection{Compostos fenólicos totais}

O teor de compostos fenólicos totais (CFT) dos filmes foi determinado pelo método colorimétrico de Folin-Ciocalteau, de acordo com o método descrito por Hillis; Swain (1959). $0,1 \mathrm{~g}$ de amostra de filme foram adicionados a $2 \mathrm{~mL}$ de metanol, sob agitação por $1 \mathrm{~h}$ e depois filtrado para obter o extrato. Em seguida, $0,5 \mathrm{~mL}$ deste extrato foram adicionados $8 \mathrm{~mL}$ de água e 0,5 mL da solução de Folin-Ciocalteu (solução aquosa 1:7). Na sequência, foi realizada agitação por 3 minutos com posterior adição de $1,0 \mathrm{~mL}$ de solução de carbonato de sódio $(0,5$ M). Os tubos foram mantidos com agitação em shaker (Solab SL-223, Piracicaba - Brasil) por 10 min e depois foi medida a absorvância a $725 \mathrm{~nm}$ em um espectrofotômetro (UV-M51 UVVisível, Bel, Brasil). O teor de CFT foi determinado utilizando uma curva padrão de ácido 
gálico (5 a $45 \mathrm{mg} . \mathrm{L}^{-1}$ ), expressos como mg de equivalente ácido gálico (EAG) por $100 \mathrm{~g}$ deamostra. Foi utilizado um branco, composto por metanol e reagentes sem o extrato. A análise foi feita em triplicata.

\subsubsection{Atividade Antioxidante}

A atividade antioxidante dos filmes foi medida pelo método de captura do radical livre ABTS $^{*+}$ (RUFINO et al., 2007). Pesou-se aproximadamente $200 \mathrm{mg}$ de amostra de filme, seguido pela adição de $2 \mathrm{~mL}$ de metanol. Esta mistura foi agitada em shaker (Solab SL-223, Piracicaba - Brasil) à temperatura ambiente $\left(\sim 25^{\circ} \mathrm{C}\right)$ durante $3 \mathrm{~h}$, na ausência de luz e depois filtrada usando papel filtro (filtro 0,45 $\mu \mathrm{m}$ Millipore, Brasil) para obter o extrato. Com este extrato metanólico obtido foram realizadas as reações com radical livre ABTS ${ }^{\bullet+}$.

O radical livre $\mathrm{ABTS}^{\circ+}$ foi preparado a partir da reação de $5 \mathrm{~mL}$ de solução de estoque de ABTS $(7 \mathrm{mM})$ com $88 \mu \mathrm{L}$ da solução de persulfato de potássio $(140 \mathrm{mM})$. A solução foi armazenada no escuro à temperatura ambiente, durante 16 horas. Após este período, $1 \mathrm{~mL}$ da solução foi diluída em álcool etílico até se obter valores de absorvância de $0,70 \mathrm{~nm} \pm 0,05$, a $734 \mathrm{~nm}$.

Finalmente, adicionou-se $3 \mathrm{~mL}$ do radical $\mathrm{ABTS}^{\bullet+}$ a $30 \mu \mathrm{L}$ de extrato, e mantida a agitação em shaker (Solab SL-223, Piracicaba - Brasil) à 250 rpm por 6 min. Após este período, determinou-se a quantidade de radical $\mathrm{ABTS}^{\bullet+}$ restante por medida da absorvância a $734 \mathrm{~nm}$ utilizando um espectrofotômetro (HP Hewlett Packard 8453, EUA). Uma curva padrão foi preparada utilizando Trolox (antioxidante sintético), em concentrações de 10 a $2000 \mu \mathrm{M}$. Os resultados da atividade antioxidante foram expressos em $\mathrm{mg}$ de equivalente Trolox (TE)/g de amostra. A análise foi feita em triplicata.

\subsubsection{Preparo do extrato das sementes de urucum e do rizoma de cúrcuma}

Para o preparo do extrato hidro-alcoólico seguiu-se a orientação do processo A da farmacopéia brasileira, adaptado por Younes; Varella; Suffredini (2000). As sementes de urucum foram removidas do fruto e secas em estufa com circulação forçada (Quimis, Q314M292, Brasil) a $40^{\circ} \mathrm{C}$, até obter-se um teor padrão de umidade de $10 \%$. Foi preparada uma solução hidro-alcoólica (etanol 70\%), na proporção de $10 \%\left(\mathrm{~m}^{-1} \mathrm{v}^{-1}\right)$. Estocou-se essa solução à 
temperatura ambiente, protegida da luz, por um período de 25 dias, procedendo-se em seguida a filtragem do material. A partir da solução filtrada, produziu-se o extrato, com auxílio de rotoevaporador a $50{ }^{\circ} \mathrm{C}$, retirando-se todo o solvente. Então, foi obtido um evaporado final que recebeu o nome de "extrato hidro-alcoólico" da semente de urucum a 10\%.

Para o preparo do extrato de cúrcuma, os rizomas foram triturados e peneirados utilizando um conjunto de peneiras de 35 e 45 mesh $(500 \mu \mathrm{m}$ e $355 \mu \mathrm{m}$ de diâmetro, respectivamente). O material peneirado foi armazenado em sacos herméticos em geladeira a 5 ${ }^{\circ}$ C. A extração de corante foi realizada em um extrator Soxhlet (MA491/6, Marconi - SP, Brasil) utilizando os solventes: etanol: isopropanol (1:1). O pigmento extraído será armazenado em frasco âmbar a $5{ }^{\circ} \mathrm{C}$ (MANIGLIA et al., 2015).

\subsubsection{Padronização do inóculo e semeadura}

Os microrganismos foram ativados pela técnica de semeadura em superfície em meio de cultura adequado. As bactérias $S$. aureus, E. coli, P. aeruginosa, L. monocytogenes, S. uberis e $S$. agalactiae foram inoculadas em meio de cultura TSA incubadas à temperatura de $37^{\circ} \mathrm{C}$ por 24 horas. Após este período, foram ressuspensas em solução fisiológica $0,9 \%(\mathrm{p} / \mathrm{v})$ até obter-se uma turvação equivalente ao padrão 1 da escala de Mac Farland, o que corresponde aproximadamente a $1,5 \times 10^{6} \mathrm{UFC} / \mathrm{mL}$. Uma alíquota de $100 \mu \mathrm{L}$ dessa suspensão foi semeada, com auxilío da alça de Drigaslk, na superfície de placas de Petri contendo $20 \mathrm{~mL}$ do meio TSA (SHADOMY e-INGROF, 1980).

Os fungos A. tamarri, A. flavus, A. fumigatus, Mucor sp, F. oxysporum, P. expansum e a levedura $C$. albicans foram inoculados em meio de cultura PDA e incubados à temperatura de $35^{\circ} \mathrm{C}$ por 48 horas. Após este período, a suspensão de esporos foi preparada com água estéril. As suspensões de esporos obtidas foram ajustadas para a concentração de $10^{4}$ conídeos $/ \mathrm{mL}$ através da contagem dos esporos em câmara de Neubauer. Em média $100 \mu \mathrm{L}$ da suspensão foram semeadas, com auxilío da alça de Drigaslk, em placas de Petri contendo $20 \mathrm{~mL}$ do meio PDA (MORAES; ALVES, 1986).

\subsubsection{Atividade antimicrobiana do extrato de urucum e do extrato de cúrcuma}

Para a avaliação da atividade antimicrobiana dos extratos de urucum e cúrcuma foi 
empregado o método da difusão em ágar (Bianco et al. 2017), utilizando os discos brancos estéreis de $6 \mathrm{~mm}$. O disco controle negativo recebeu $20 \mu \mathrm{L}$ de etanol, os demais discos receberam $20 \mu \mathrm{L}$ de extrato. Em todos os ensaios, após a semeadura dos microrganismos, o disco controle negativo (etanol) e os discos contendo extratos de urucum e de cúrcuma foram distribuídos como na ordem apresentada no teste com Aspergillus fumigatus, na Figura 4.2 A. Foi mantida distância entre os discos para evitar interferências entre os possíveis halos de inibição. Após este procedimento, as placas foram fechadas, invertidas e incubadas a $37^{\circ} \mathrm{C}$ para bactérias e a $35^{\circ} \mathrm{C}$ para leveduras e fungos. Após $24 \mathrm{~h}$ de incubação foi realizada a leitura dos resultados, que consistiu na medição do diâmetro dos halos de inibição.

\subsubsection{Teste do Halo}

Para a avaliação da atividade antimicrobiana dos filmes de farinha de urucum WS, AS e KS foi empregado o teste do halo (BARRY; THORNSBERRY, 1991). Os filmes de farinha de urucum foram cortados em discos com aproximadamente $2,5 \mathrm{~cm}$ de diâmetro, em seguida foram expostos a UV por 5 minutos em cada face. Após as semeaduras de $100 \mu \mathrm{L}$ da suspensão dos microrganismos, com auxílio da Alça de Drigalsk, os filmes foram colocados assepticamente sobre a superfície do meio de cultura inoculado. As placas foram incubadas em temperaturas específicas, $37^{\circ} \mathrm{C}$ bactérias e $35^{\circ} \mathrm{C}$ fungos e levedura, por 48 horas. Para todos os ensaios realizados, o filme de amido de mandioca foi utilizado como controle negativo.

\subsection{Resultados e discussão}

\subsubsection{Aspecto visual}

Os filmes de farinha de urucum WS, AS, e KS, apesar da coloração intensa, apresentaram transparência, como pode ser vista na Figura 4.1. É possível enxergar o fundo quadriculado atrás do filme, indicando que este material não bloqueia totalmente a passagem de luz. 
Figura 4.1 - Aparência dos filmes elaborados com as farinhas de urucum AS, WS e KS

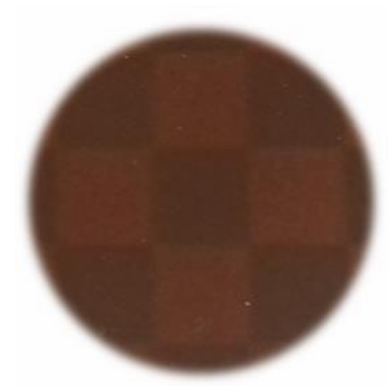

WS

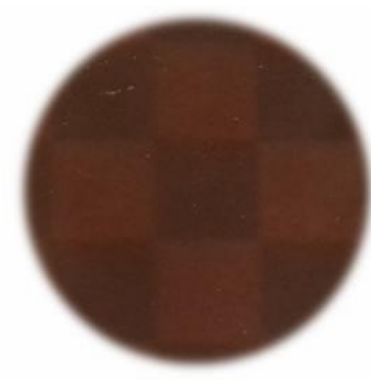

AS

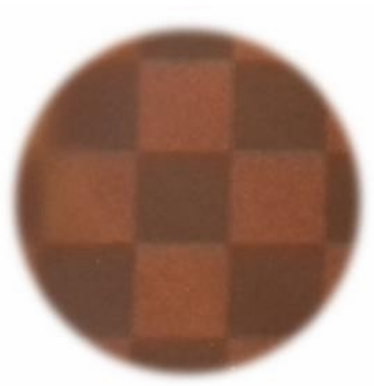

KS

\subsubsection{Compostos ativos}

Foram realizadas análises de determinação de compostos fenólicos totais, carotenoides totais, teor de bixina e atividade antioxidante dos filmes de farinha de urucum WS, AS e KS. Os resultados estão apresentados na Tabela 4.1.

Tabela 4.1 - Fenólicos totais, carotenoides totais, teor de bixina e atividade antioxidante de filmes de farinha de urucum

\begin{tabular}{ccccc}
\hline Filme & $\begin{array}{c}\text { Fenólicos totais } \\
\text { (mg GAE/ 100 g } \\
\text { de amostra) }\end{array}$ & $\begin{array}{c}\text { Carotenoides totais } \\
\text { ( } \begin{array}{c}\text { (g carotenóides/g de } \\
\text { amostra) }\end{array}\end{array}$ & $\begin{array}{c}\text { Bixina } \\
\text { (g bixina/100 } \\
\text { g de amostra) }\end{array}$ & $\begin{array}{c}\text { AA } \\
\text { (mg TE/g de } \\
\text { amostra) }\end{array}$ \\
\hline WS & $459,51 \pm 0,20^{\mathrm{b}}$ & $210,16 \pm 0,91^{\mathrm{b}}$ & $0,40 \pm 0,05^{\mathrm{b}}$ & $1,1 \pm 0,21^{\mathrm{b}}$ \\
AS & $522,30 \pm 0,60^{\mathrm{a}}$ & $213,47 \pm 0,70^{\mathrm{a}}$ & $0,77 \pm 0,09^{\mathrm{a}}$ & $1,5 \pm 0,11^{\mathrm{a}}$ \\
KS & $204,49 \pm 0,20^{\mathrm{c}}$ & $66,79 \pm 0,80^{\mathrm{c}}$ & $0,30 \pm 0,08^{\mathrm{c}}$ & $0,8 \pm 0,12^{\mathrm{c}}$ \\
\hline
\end{tabular}

AA: atividade antioxidante, WS: moagem em água, AS: moagem em $\mathrm{pH}$ ácido, KS: moagem em $\mathrm{pH}$ alcalino.

a,b,c: letras diferentes em uma mesma coluna indicam diferença significativa entre os filmes de farinhas WS, AS e KS, de acordo com o teste de Tukey $(\mathrm{p}<0,05)$.

Os filmes apresentaram diferença significativa, de acordo com o teste de Tukey $(\mathrm{p}<0,05)$ para teor de fenólicos totais, carotenoides totais, teor de bixina e atividade antioxidante dos filmes de farinha de urucum WS, AS e KS.

O teor de compostos fenólicos, carotenoides, bixina e atividade antioxidante dos filmes elaborados com as farinhas de urucum (WS, AS e KS) são menores do que dos materiais iniciais (farinhas WS, AS e KS), basta comparar os resultados apresentados na Tabela 4.1 deste capítulo, com a Tabela 2.3 do capítulo 2 .

Os filmes de farinha de urucum apresentaram redução de compostos fenólicos totais (WS: 68,4\%, AS: 66,7\%, e KS: 84\%), carotenoides (WS: 70,7\%, AS: 72,6\%, e KS: 87,8\%), 
bixina (WS: 96,9\%, AS: 93\%, e KS: 97,3\%), atividade antioxidante por ABTS (WS: 35\%, AS: 41\%, e KS: 60\%) quando comparado com os materiais iniciais (farinhas AS, WS e KS). Os compostos ativos são sensíveis à temperatura e provavelmente foram degradados na etapa de elaboração dos filmes, durante o aquecimento a $85{ }^{\circ} \mathrm{C}$ por 2 horas (SCHIOZER; BARATA, 2007). FRATIANNI; CINQUANTA; PANFILI, (2010) verificaram que a degradação de carotenoides é influenciada por temperatura e tempo de aquecimento ao observarem a redução de $50 \%$ de todos os carotenóides expostos a $85{ }^{\circ} \mathrm{C}$, após 1 minuto de aquecimento. Segundo Castro, (2016), os compostos fenólicos podem sofrer degradação em altas temperaturas.

Maniglia et al. (2015) ao elaborarem filmes com farinha do resíduo de cúrcuma, observaram comportamento semelhante quanto à redução dos compostos ativos; houve redução de $79 \%$ de curcumina, $91 \%$ de demetoxicurmina, $61 \%$ de bisdemetoxicurcumina e $31 \%$ de atividade antioxidante em relação ao material inicial.

Apesar da redução de compostos ativos em todos os filmes produzidos, nota-se que houve uma manutenção das proporções de compostos ativos nos filmes com relação às respectivas farinhas (material inicial: WS, AS, KS) utilizadas na produção. Os filmes de farinha KS apresentaram menores teores de compostos fenólicos, de carotenoides, de bixina e de atividade antioxidante do que os filmes de farinhas WS e AS. No isolamento da farinha KS, em pH alcalino, ocorreu a saponificação da bixina, principal carotenoide, produzindo a norbixina, e esta, durante processo de neutralização do $\mathrm{pH}$, é perdida por ser solúvel em água (MORTENSEN, 2006). Em pH alcalino, a bixina também pode sofrer isomerização, reduzindo, então, seu poder antioxidante (RIOS; MERCADANTE; BORSARELLI, 2007). Ainda em pH alcalino, os compostos fenólicos sofrem oxidação (OLIVEIRA, 2015). Os filmes de farinha AS também sofreram redução de compostos ativos, em menores proporções, assim como os filmes de farinha WS, quando comparados aos filmes de farinha KS. Os filmes de farinha AS apresentaram maiores teores de compostos fenólicos totais, de carotenoides, de bixina e de atividade antioxidante do que os filmes de farinhas WS e KS. O ácido ascórbico, utilizado durante o isolamento da farinha, pode ter aumentado a estabilidade dos fenólicos presentes (OETARI et al., 1996), como de outros compostos ativos. Além do fato que a presença residual do ácido ascórbico, nesta farinha, também pode contribuir com a sua ação antioxidante (HASSIMOTTO; GENOVESE; LAJOLO, 2005).

A atividade antioxidante dos filmes produzidos com farinhas de urucum (W, AS, KS) neste trabalho, mostrou-se menor que a atividade antioxidante reportada por Maniglia et al. 
(2015) ao produzir filmes de farinha de cúrcuma com atividade antioxidante de 46,4\%.

\subsubsection{Atividade antimicrobiana dos extratos de urucum e cúrcuma}

As Figuras 4.2 e 4.3 apresentam os resultados da avaliação da atividade antimicrobiana dos extratos de urucum e cúrcuma contra bactérias, fungos e leveduras.

Os extratos de urucum e de cúrcuma não apresentaram atividade antimicrobiana contra os fungos, pois não houve aparecimento de halo de inibição. Contudo, ao observar a Figura 4.2, nota-se que em alguns casos, os extratos reduziram a esporulação de alguns fungos. Isto pode ser observado em A. fumigatus (Figura 4.2 A) e Mucor sp. (Figura 4.2 E) na presença do extrato de urucum, e em A. tamarri (Figura 4.2 B), A. flavus (Figura 4.2 C), F. oxysporum (Figura 4.2 D) e P. expansum (Figura 4.2 F) na presença de extrato de cúrcuma. A literatura reporta estudos de extratos brutos e óleos essenciais de plantas, tais como alecrim, orégano, pitanga, romã, manjericão e outros que têm sido empregados para inibição de crescimento micelial e esporulação de fungos fitopatogênicos (SCHWAN-ESTRADA; STANGARLIN; CRUZ, 2000). De modo geral, o modo de ação destes compostos sobre os fungos, com relação à redução da esporulação, está baseado na desorganização celular, ruptura de membranas e inibição de enzimas fúngicas. Estes efeitos causam a inibição da germinação e elongação do tubo germinativo e redução ou inibição do crescimento micelial (LO et al.(1996).

Os extratos de urucum e de cúrcuma apresentaram atividade antimicrobiana contra algumas bactérias, pois houve aparecimento de pequenos halos de inibição, como podem ser vistos na Figura 4.3. Os valores dos halos de inibição estão apresentados na Tabela 4.2. 
Tabela 4.2 - Atividade antimicrobiana de extratos de urucum, e cúrcuma

\begin{tabular}{ccc}
\hline Microrganismo & Extrato & Diâmetro do halo \\
\hline Sthapylococcus aureus & Urucum & $7,5 \mathrm{~mm}$ \\
(Figura 4.3 A) & Cúrcuma & $8,0 \mathrm{~mm}$ \\
Sthapylococcus uberis & Urucum & $9,8 \mathrm{~mm}$ \\
(Figura 4.3 B) & Cúrcuma & $10,2 \mathrm{~mm}$ \\
Sthapylococcus agalactiae & Urucum & $9,0 \mathrm{~mm}$ \\
(Figura 4.3 C) & Cúrcuma & $12,5 \mathrm{~mm}$ \\
Pseudomonas aeroginosa & Urucum & Não houve halo \\
(Figura 4.3 D) & Cúrcuma & Não houve halo \\
Escherichia coli & Urucum & Não houve halo \\
(Figura 4.3 E) & Cúrcuma & Não houve halo \\
Candida albicans & Urucum & Não houve halo \\
(Figura 4.3 F) & Cúrcuma & $7,5 \mathrm{~mm}$ \\
\hline
\end{tabular}

A literatura reporta atividade antimicrobiana de extratos hidro-alcoólicos de diferentes partes da espécie Bixa orellana, tais como raiz, caule, folhas, sementes (CASTELLO et al., 2002). A atividade antimicrobiana do extrato hidro-alcoólico das sementes é menos explorada, quando comparada às demais partes da planta, já que as sementes já são utilizadas na extração de corante, enquanto as outras partes da planta não são exploradas.

Segundo Mors; Rizzini; Pereira, (2000), no arilo ceroso da semente há óleo essencial rico em E-geranilgeraniol, monoterpenos e sesquiterpenos oxigenados, fenilalanina, treonina, triptofano e ácidos elágico, salicílico e tomentosico, além dos carotenóides bixina, norbixina, isobixina, bixeína, bixaghaneno, crocetina, bixol, responsáveis por sua cor e alfa e betacaroteno em teores mais baixos.

Fleischer et al. (2003) ao fazerem uma triagem de extrato hidro-alcoólico (70\%) de sementes de urucum, conseguiram identificar a presença de flavonoides, saponinas, fenólicos e óleos. Neste mesmo trabalho foi verificada a atividade antimicrobiana contra $S$. aureus (17 $\mathrm{mm})$, P. aeroginosa $(19 \mathrm{~mm})$, E. coli $(18 \mathrm{~mm})$, C. albicans $(20 \mathrm{~mm})$. Gonçalves; Filho; Menezes, (2005) relataram atividade antimicrobiana do extrato de sementes de urucum contra S. pyogenes, Proteus mirabilis e $S$. aureus, enquanto E. coli e $P$. aeruginosa foram resistentes ao extrato. 
Figura 4.2 - Avaliação da atividade antimicrobiana dos extratos hidro-alcoólicos de urucum e cúrcuma contra fungos filamentosos

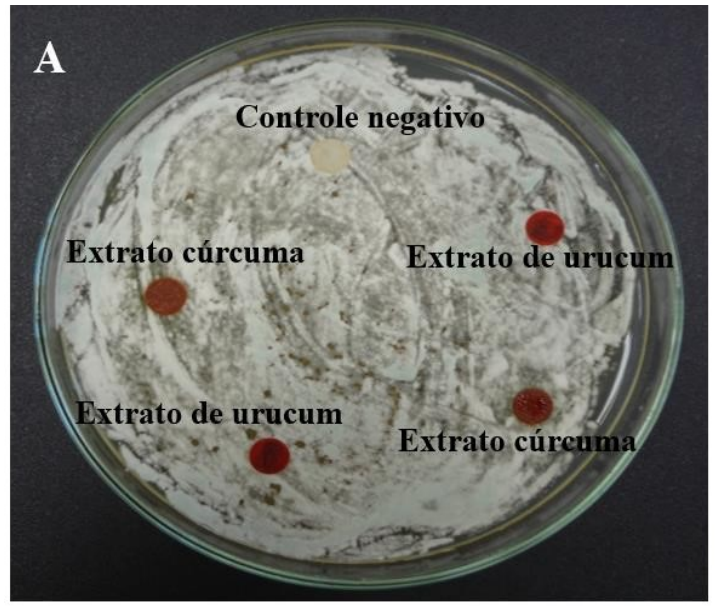

Aspergillus fumigatus

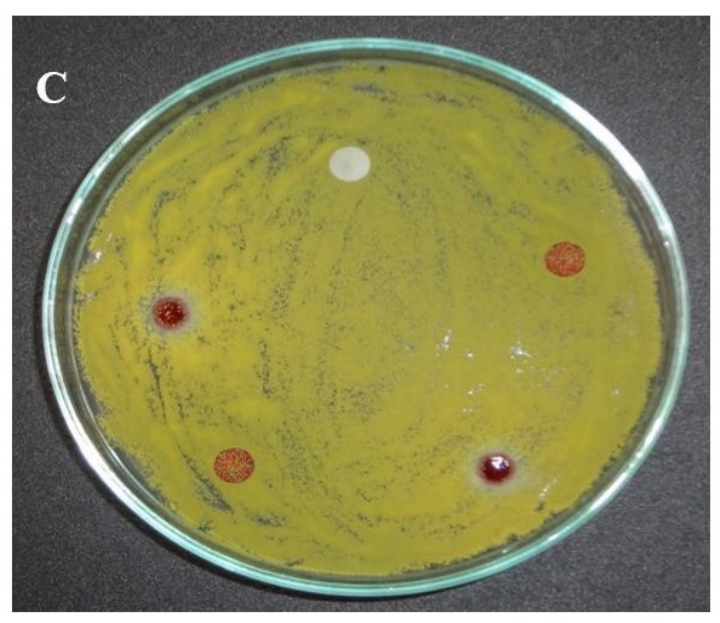

Aspergillus flavus

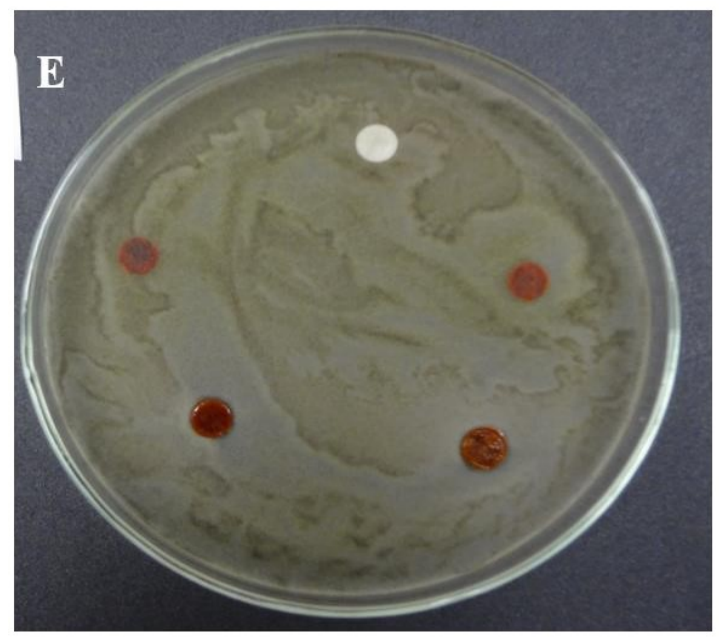

Mucor sp

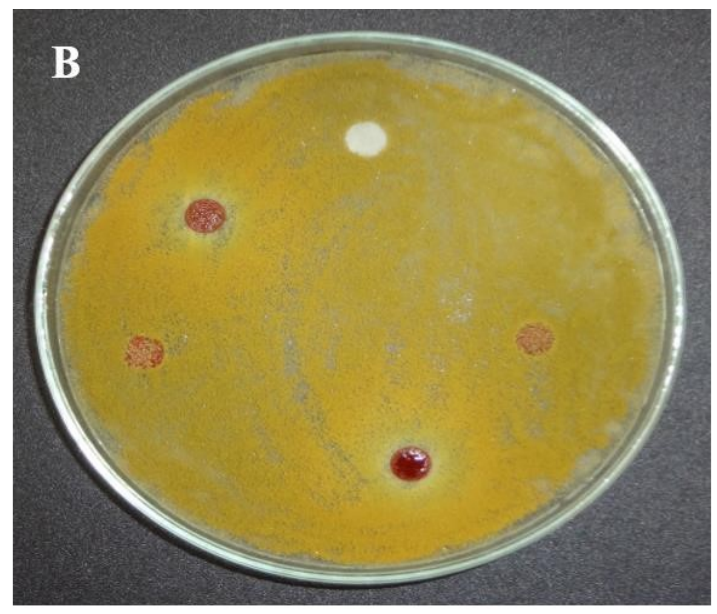

Aspergillus tamarri

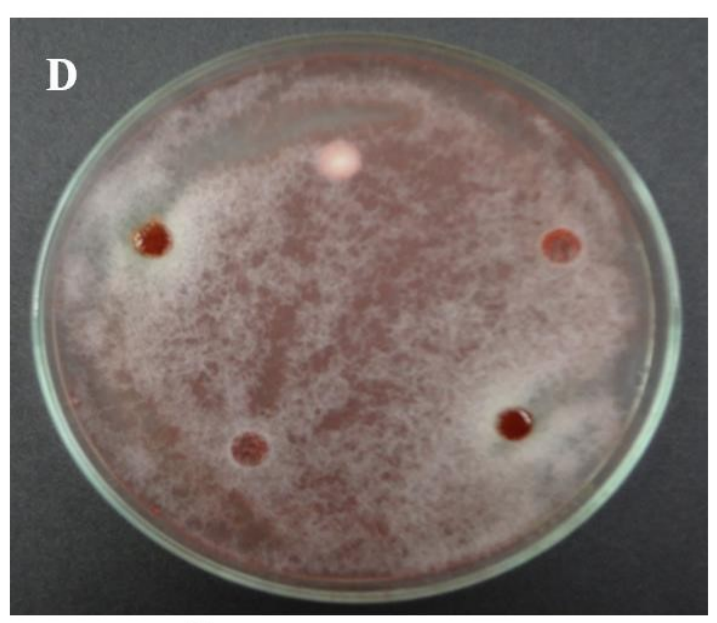

Fusarium oxysporum

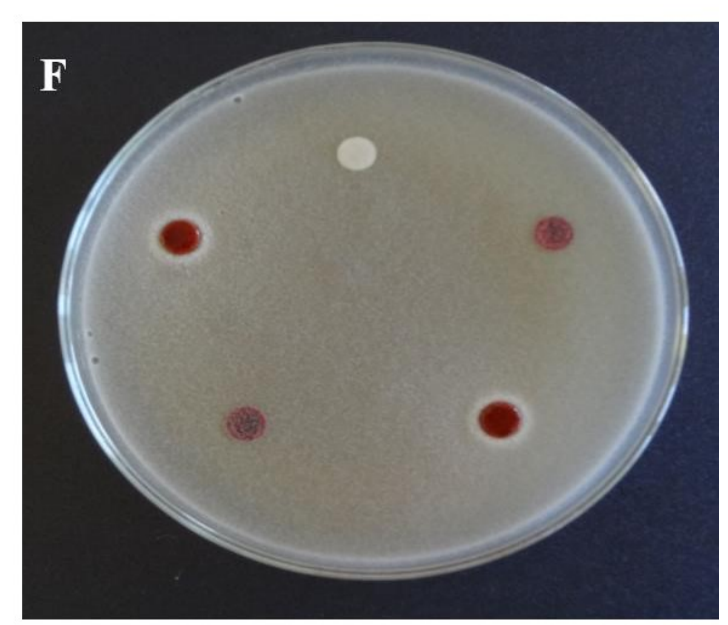

Penicillium expansum 
Figura 4.3 - Avaliação da atividade antimicrobiana dos extratos hidro-alcoólicos de urucum e cúrcuma contra bactérias e levedura

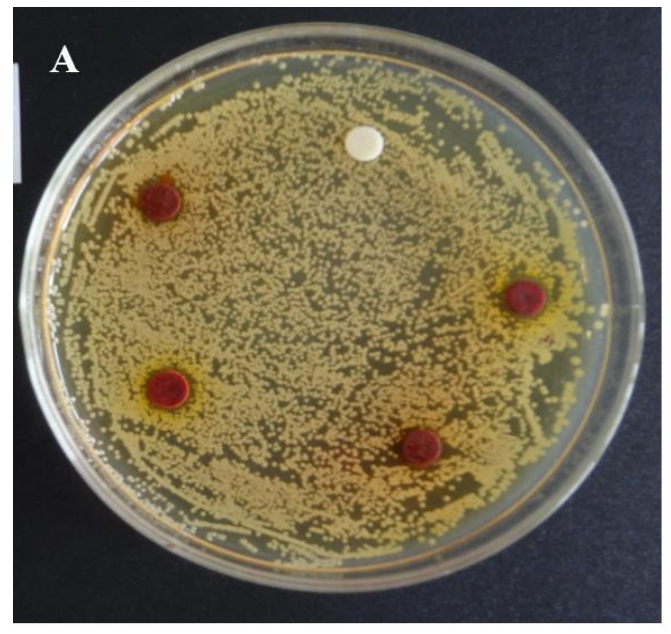

Sthapylococcus aureus

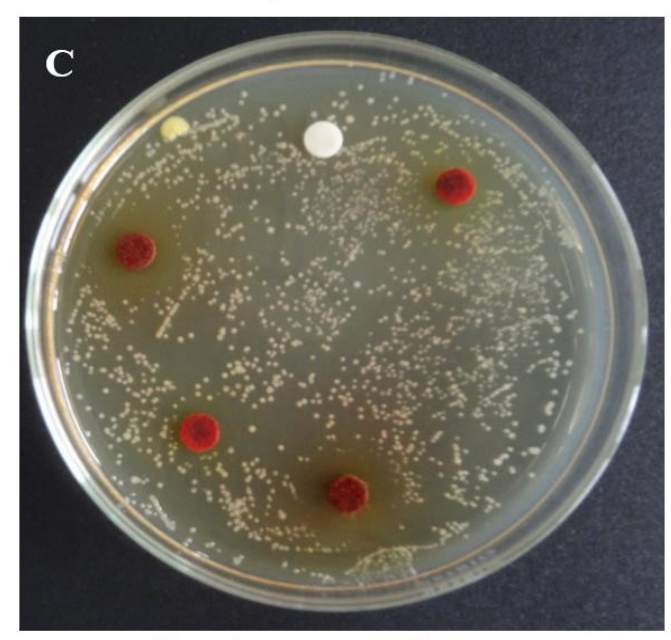

Sthapylococcus agalactiae

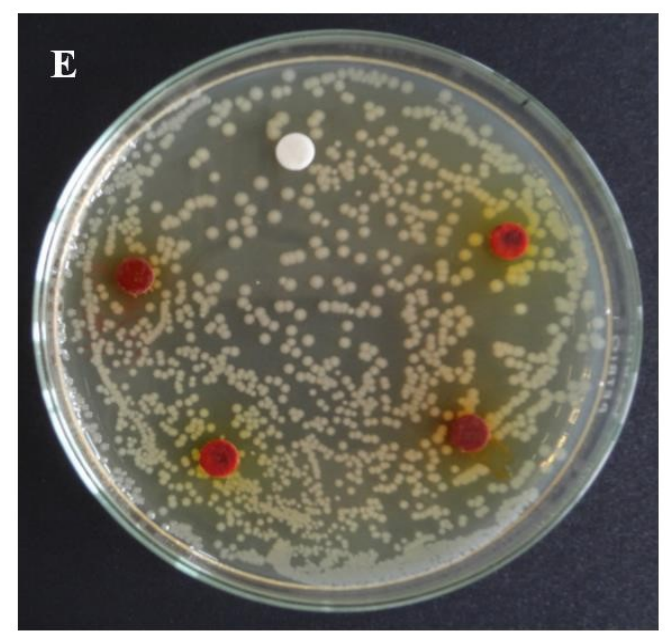

Escherichia coli

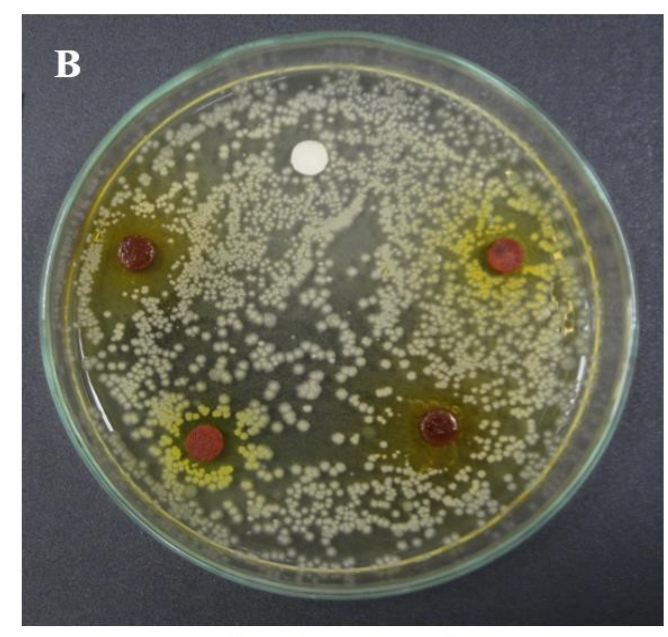

Sthapylococcus uberis

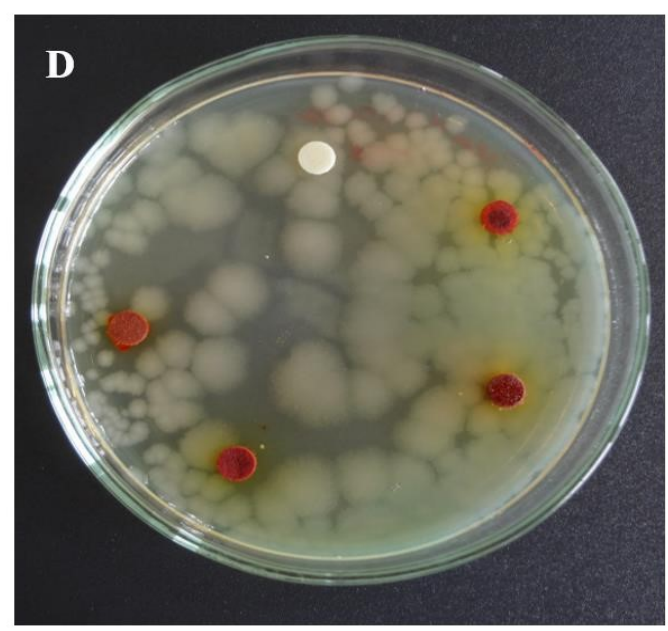

Pseudomonas aeroginosa

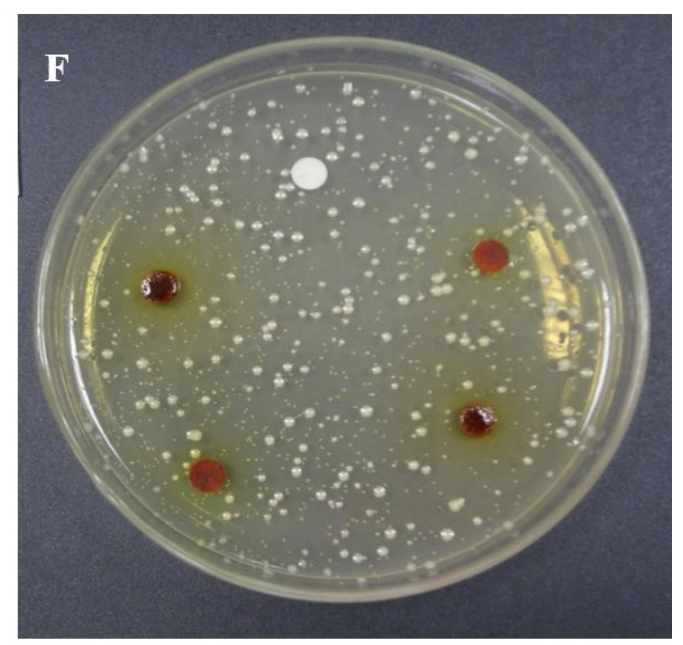

Candida albicans 
Irobi; Moo-Young; Anderson, (1996) avaliaram a atividade antimicrobiana de extrato de folhas contra bactérias e fungos. Neste trabalho, foram determinadas a concentração inibitória mínima (4-16 mg/mL) e a concentração inibitória máxima (16-64 mg/mL). Em ensaio de difusão de disco em ágar, com extrato a $5 \mathrm{mg} / \mathrm{mL}$ foi verificada ação contra Bacillus subtilis $(15 \mathrm{~mm})$, S. aureus $(17 \mathrm{~mm})$ e Streptococcus faecalis $(17 \mathrm{~mm})$ e pequena atividade contra $E$. coli $(2 \mathrm{~mm})$, Serratia marcescens $(1 \mathrm{~mm})$, C. albicans $(3 \mathrm{~mm})$, e Aspergillus niger $(3 \mathrm{~mm})$. Neste estudo, as bactérias gram-positivas mostraram-se mais sensíveis, provavelmente devido a composição química de sua membrana, que permite ação do composto antimicrobiano. $\mathrm{O}$ extrato contém diversos compostos fitoquímicos que se difundem em taxas diferentes, além de concentrações e ações distintas, podendo então justificar as diferentes zonas de inibição (IROBI; MOO-YOUNG; ANDERSON, 1996)

Shilpi et al. (2006) fizeram a triagem fitoquímica da raiz, folhas e sementes de urucum. Na semente de urucum foi relatada a presença de carotenóides, como a bixina e norbixina, terpenoides, tocotrienois e flavonoides. Apenas o extrato das folhas de urucum foi testado neste trabalho e se mostrou ativo contra E. coli, S. aureus e Shigella dysenteriae.

Shahid-ul-islam; Rather; Mohammad, (2015) relataram a presença de fitoquímicos em todas as partes da Bixa orellana, como carotenóides, apocarotenóides, terpenos, terpenoides, esteróis, compostos alifáticos. Em especial, as sementes contêm bixina, norbixina e, em quantidades menores, criptoxantina, luteína e zeaxantina. O principal composto antimicrobiano nas sementes de urucum são 9`'-cis-norbixina e all-trans-norbixin (GALINDO-CUSPINERA; LUBRAN; RANKIN, 2002). A ação antifúngica está associada principalmente a óleos essenciais, terpenos, taninos, alcaloides (ZHAI et al., 2014). Foi verificada ação antifúngica contra Trychophyton mentagophytes e Trychophyton rubrum com CIM $>8 \mathrm{mg} / \mathrm{mL}$, Cryptococcus neoformans e Microsporum gypseum com MIC de $8 \mathrm{mg} / \mathrm{mL}$ e $2 \mathrm{mg} / \mathrm{mL}$, respectivamente (SHAHID-UL-ISLAM; RATHER; MOHAMMAD, 2015) .

Apesar dos relatos na literatura consultada indicarem uma evidente atividade antimicrobiana de extratos hidro-alcoólicos de Bixa orellana contra diversos microrganismos, os resultados obtidos neste trabalho, nos ensaios com extrato das sementes contra bactérias, levedura e fungos foram menos eficientes, com halos de inibição menores (Tabela 4.2) aos reportados pela literatura. Embora os halos de inibição identificados no presente trabalho seja menores aos reportados, ainda podem ser considerados, pois segundo Feitor, (2010), se a zona 
de inibição observada for maior que $1 \mathrm{~mm}$, o efeito antimicrobiano pode é considerado como bom.

O efeito inibidor depende da concentração dos compostos ativos. Os teores de bixina, principal agente antimicrobiano podem variar de acordo com questões ambientais e variabilidade genética, podendo variar de 1 a $6 \%$ (FRANCO et al., 2002). Logo, não se sabe ao certo, quão pura são as espécies de Bixa orellana do presente trabalho e as estudas pela literatura. Além deste fator, o efeito inibidor depende da sensibilidade das espécies de microrganismos aos agentes antimicrobianos. Há estudos que relatam a maior resistência de bactérias Gram negativas em relação a menor resistência de bactérias Gram positivas, quando testadas contra antibióticos. Os microrganismos empregados não tiveram suas resistências testadas contra antibióticos comerciais no presente estudo, o que dificulta uma comparação mais acurada, mas de modo geral pode-se afirmar que os extratos tiveram efeito de inibição do crescimento em bactérias Gram positivas $S$. aureus, S. agalactiae, S. uberis (FURLANETTO, 2014).

A literatura também reporta a atividade antioxidante e antimicrobiana da cúrcuma (AKRAN et al., 2010). A partir da cúrcuma é possível produzir o pó de cúrcuma, óleo resina com teores de 30 a $40 \%$ de pigmentos expressos em curcumina e óleo volátil de 15 a $25 \%$, óleo essencial e extrato de curcumina (FILHO et al., 2000). Na cúrcuma estão presentes três pigmentos curcuminóides: a curcumina, a desmetoxicurcumina e a bisdesmetoxicurcumina. No rizoma de cúrcuma estes pigmentos podem estar em concentrações variáveis de 4 a 6 mg/100 g para curcumina; de 4 a $3 \mathrm{mg} / 100 \mathrm{~g}$ para desmetoxicurcumina, e de 3 a $2 \mathrm{mg} / 100 \mathrm{~g}$ para a bisdesmetoxicurcumina (PEREIRA; STRINGHETA, 1998; PÉRET-ALMEIDA et al., 2008). O óleo essencial, a curcumina e o óleo resina da cúrcuma são os responsáveis pela atividade antioxidante natural e ação antimicrobiana contra bactérias, fungos, leveduras e parasitas. O extrato obtido no presente trabalho aproxima-se de um óleo resina, no qual os compostos ativos estão concentrados (FILHO et al., 2009).

Rolim, (2004) verificou que ao incorporar $2 \%$ de óleo resina de cúrcuma em queijos houve redução da concentração de $S$. aureus de $10^{8}$ para $10^{6} \mathrm{UFC} / \mathrm{mL}$.

Péret-Almeida et al. (2008) avaliou a ação antimicrobiana de curcumina, óleo essencial e óleo resina de cúrcuma contra S. aureus, Bacillus subtilis, Salmonela chorelaesuis, E. coli, Aspergillus niger, Sacharomices cerevisae, C. albicans. O óleo essencial, na CIM (90 $\mu \mathrm{g})$ apresentou halo de inibição $(10 \mathrm{~mm})$ para E. coli e $(18 \mathrm{~mm})$ para B. subtilis $)$. Não foram 
identificados halo de inibição contra os microrganismos em presença de extratos de curcumina e óleo resina.

Aqui, é importante salientar que o teste do halo dos extratos de urucum e cúrcuma foram realizados apenas para uma avaliação qualitativa do efeito antimicrobiano dos extratos testados, e que para uma avaliação mais completa, seria necessário a realização de testes quantitativos para conhecimento da Concentração Mínima Inibitória (CIM). Que serão realizados em trabalhos futuros.

\subsubsection{Teste do Halo dos filmes de farinhas de urucum}

O teste do halo foi realizado com o objetivo de avaliar a eficiência antimicrobiana dos filmes de farinha de urucum WS, AS e KS. Os resultados do teste do halo dos filmes de farinha WS, AS e KS estão apresentados nas Figuras de 4.4 a 4.16.

Não houve aparecimento de halo de inibição para nenhum filme de farinha de urucum WS, AS, e KS testados contra bactérias, fungos ou levedura. O halo de inibição é proporcional à concentração do agente antimicrobiano na matriz. As concentrações de bixina, um dos principais responsáveis pela atividade antimicrobiana nos filmes de farinha de urucum WS, AS e KS foram baixas (WS: 0,40, AS: 0,77, KS:0,30 g/100g). Os baixos teores são devido a degradação ao longo do processo, desde a extração do pigmento na indústria, isolamento das farinhas e elaboração dos filmes.

Tradicionalmente, não é comum encontrar variedade em filmes naturalmente antimicrobianos. Os filmes de quitosana são naturalmente antimicrobianos e ainda assim são incorporados agentes antimicrobianos para melhorar desempenho. Yuan; Chen; Li, (2016) verificou o aumento da atividade antimicrobiana de filmes de quitosana ao incorporar óleos essenciais. A literatura reporta maior número de trabalhos de filmes antimicrobianos que tiveram a incorporação de agente antimicrobiano na matriz. Carvalho et al. (2017) produziram filme antimicrobiano de acetato de celulose incorporados de uma suspensão de curcumina. Krepker et al. (2017) produziram filme antimicrobiano utilizado para embalar "hummus" a partir da combinação sinérgica de óleos essenciais, timol e carvacrol.

Em todos os filmes de farinha de urucum WS, AS e KS houve crescimento de fungos sobre toda a superfície dos filmes, possivelmente porque as concentrações de compostos antimicrobianos de ação antifúngica são baixíssimas (SHAHID-UL-ISLAM; RATHER; 
MOHAMMAD, 2015). De acordo com Feitor, (2010), a atividade antimicrobiana pode ser considerada insuficiente.

Contudo, em alguns casos, não houve crescimento de bactérias e levedura sobre a superfície de filmes de farinha de urucum. Em contrapartida, houve crescimento sobre toda a superfície do filme controle negativo (filme de amido de mandioca), quando testado contra as mesmas bactérias e levedura.

Os filmes de farinha de urucum WS, no geral, permitiram crescimento de bactérias e levedura abaixo do filme, ao redor e sobre o filme; logo, não apresentaram atividade antimicrobiana que, de acordo com Feitor, (2010) a atividade antimicrobiana pode ser considerada insuficiente. Em alguns casos, os filmes de farinha AS também não apresentaram nenhuma atividade antimicrobiana, pelas mesmas situações descritas, para os filmes de farinha WS, como nos testes com Staphylococcus uberis, Staphylococcus agalactiae e Candida albicans. Já os filmes de farinha KS não apresentaram crescimento por baixo do filme, nem ao redor ou sobre para todas as bactérias testadas e para a levedura Candida albicans, com exceção apenas da bactéria Sthapylococcus agalactiae. De acordo com Fortes (2010), a capacidade antimicrobiana deste filme pode ser considerada de boa com a tendência a limitada por ser observado o crescimento de Sthapylococcus agalactiae sobre o filme.

De acordo com os resultados de compostos fenólicos, carotenoides e bixina, os filmes de farinha WS e AS apresentaram maiores teores de compostos ativos, quando comparados ao filme de farinha KS. Esperava-se que a resposta antimicrobiana dos filmes de farinha WS e AS fosse proporcional aos maiores teores de compostos ativos. Contudo, foi o filme KS o de melhor resultado com relação a atividade antimicrobiana. Este comportamento pode ser justificado de acordo com os resultados de caracterizações funcionais (Capítulo 3), quando o filme de farinha KS se mostrou mais hidrofóbico, menos solúvel e com menor absorção de água que os demais filmes de farinha WS e AS. 
Figura 4.4 - Teste do halo dos filmes de farinhas de urucum (WS, AS e KS) com Staphylococcus aureus (5 x 104 UFC)

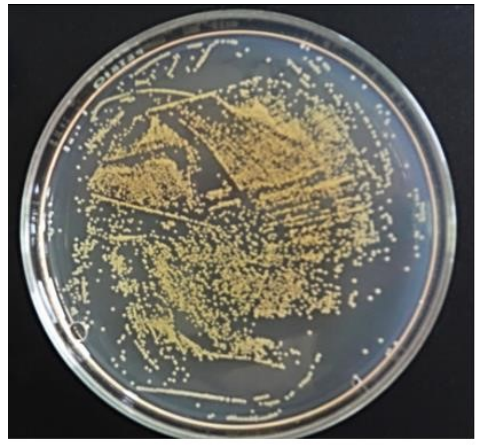

Controle

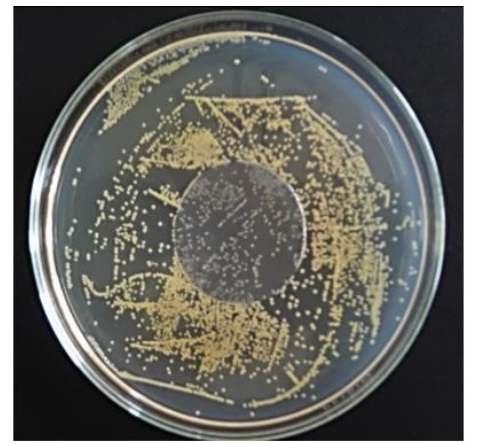

Filme controle de amido de mandioca

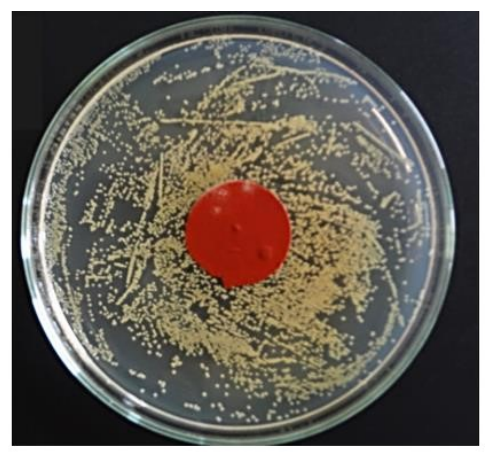

Filme de farinha WS

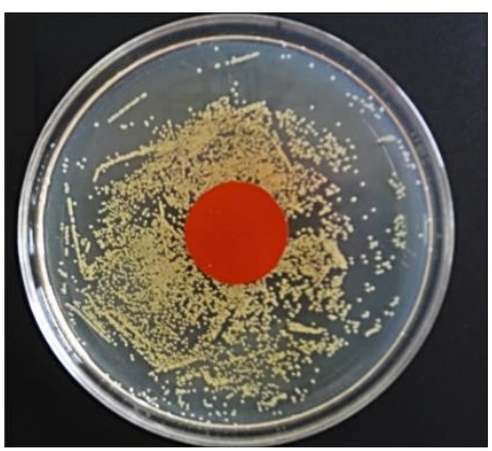

Filme de farinha AS

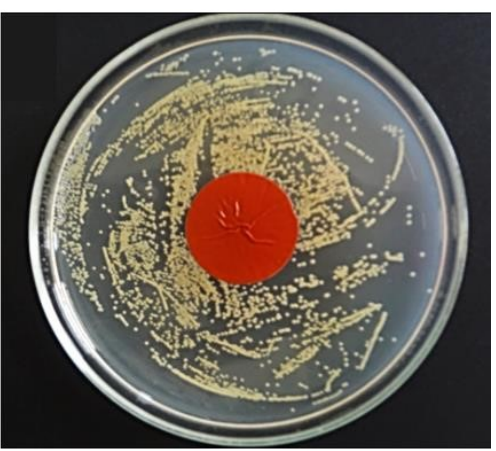

Filme de farinha KS

Figura 4.5 - Teste do halo dos filmes de farinhas de urucum (WS, AS e KS) com Staphylococcus uberis (5 x 104 UFC)

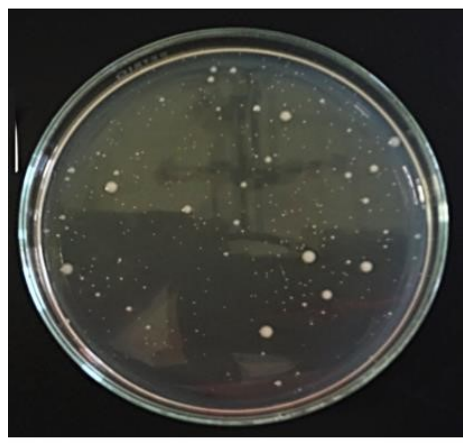

Controle

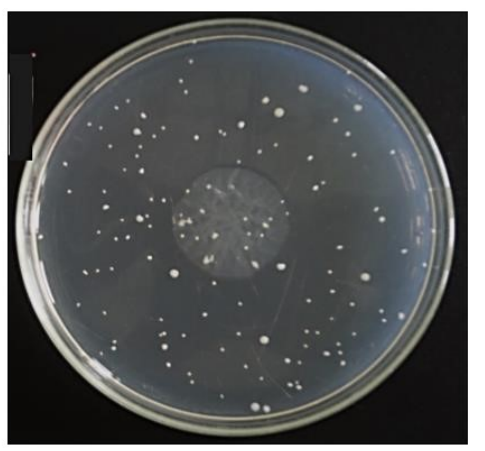

Filme controle de amido de mandioca

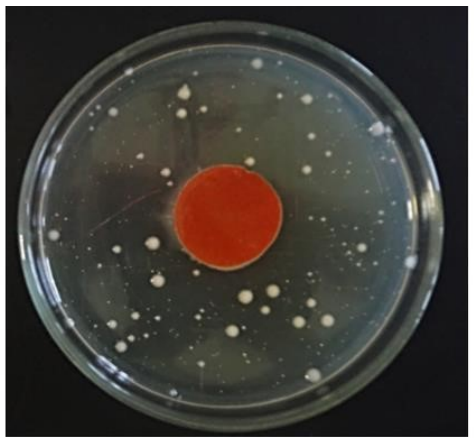

Filme de farinha WS

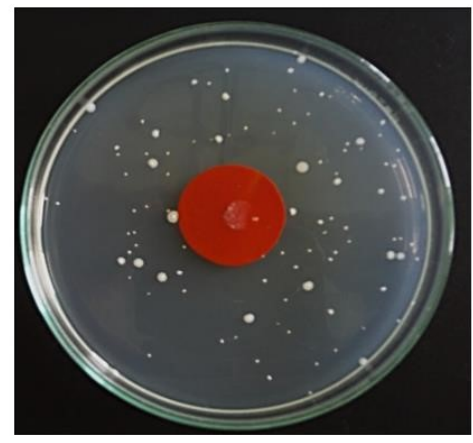

Filme de farinha AS

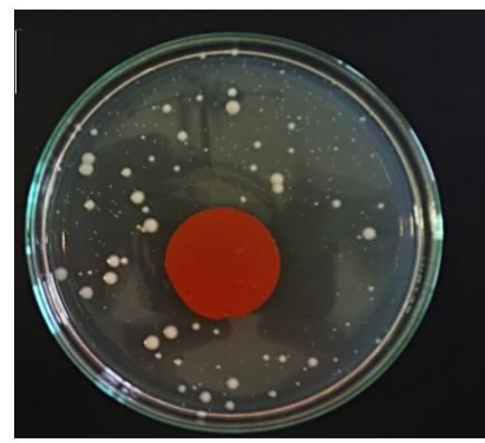

Filme de farinha KS 
Figura 4.6 - Teste do halo dos filmes de farinhas de urucum (WS, AS e KS) com Staphylococcus agalactiae (5 x 10 $\left.{ }^{4} \mathrm{UFC}\right)$

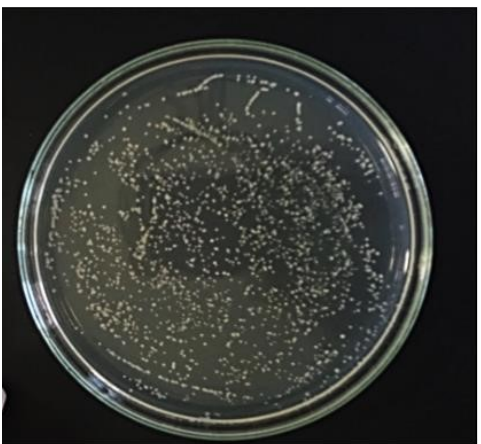

Controle

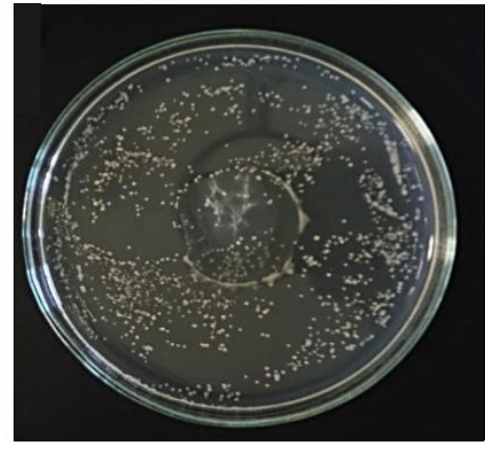

Filme controle de amido de mandioca

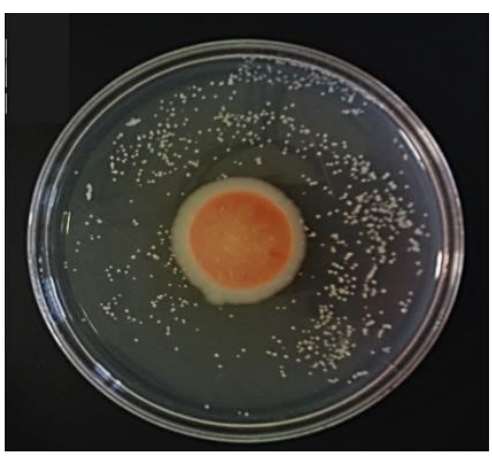

Filme de farinha WS

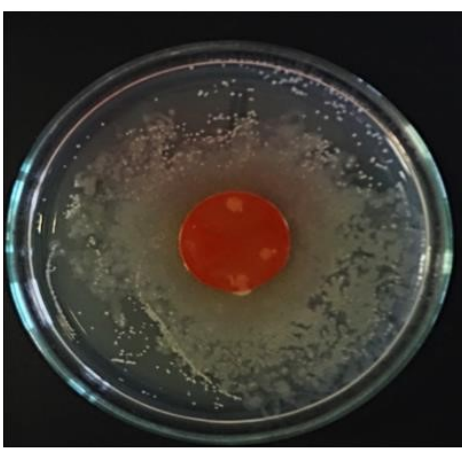

Filme de farinha AS

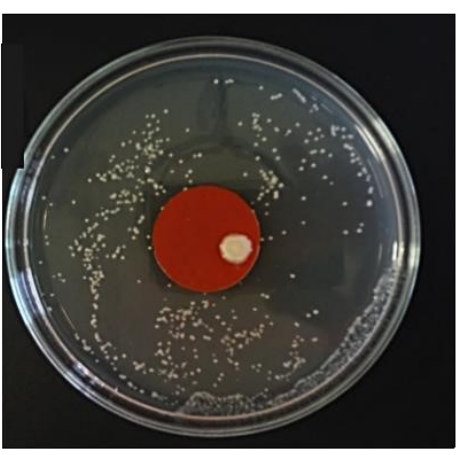

Filme de farinha KS

Figura 4.7 - Teste do halo dos filmes de farinhas de urucum (WS, AS e KS) com Listeria monocytogenes (5 x 10 $\left.{ }^{4} \mathrm{UFC}\right)$

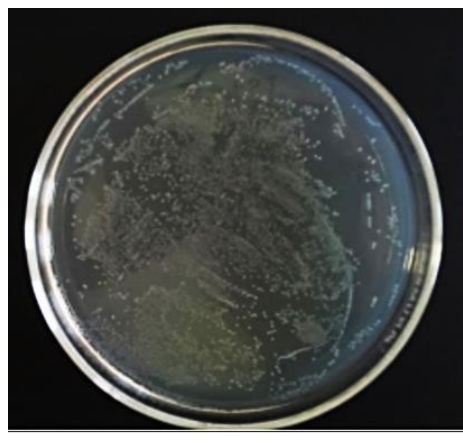

Controle

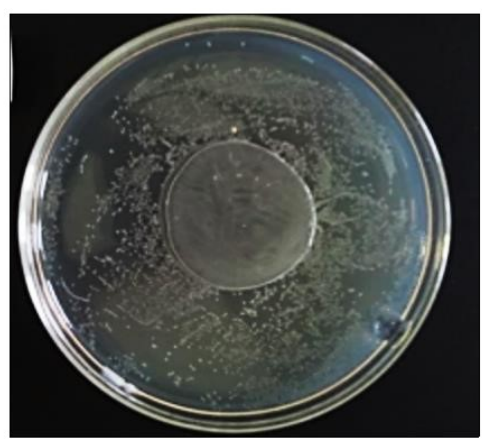

Filme controle de amido de mandioca

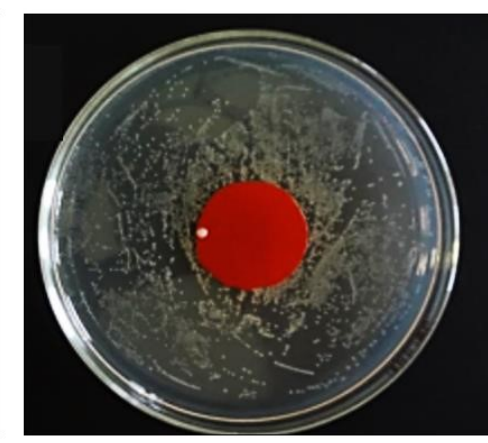

Filme de farinha WS

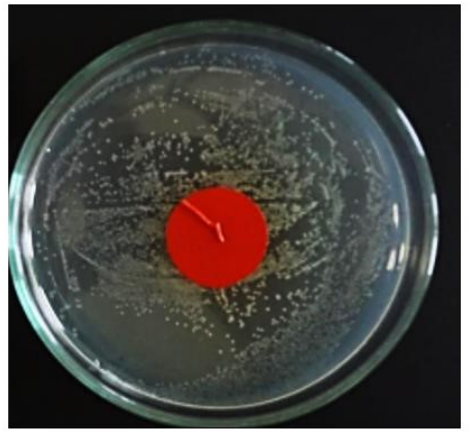

Filme de farinha AS

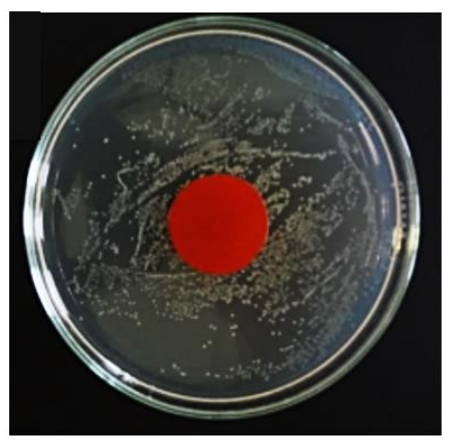

Filme de farinha KS 
Figura 4.8 - Teste do halo dos filmes de farinhas de urucum (WS, AS e KS) com Pseudomonas aeroginosa (5 x 1044FC)

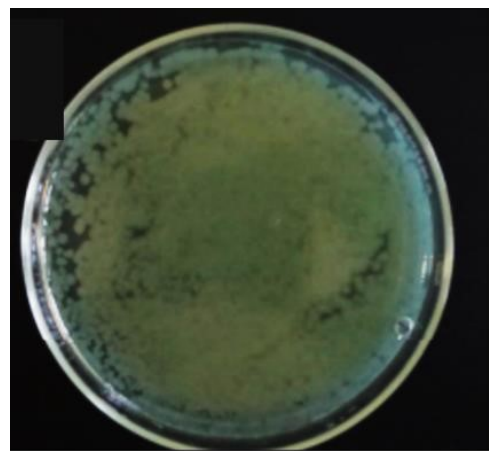

Controle

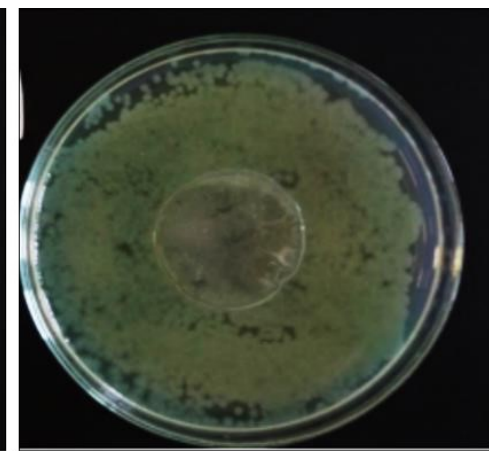

Filme controle de amido de mandioca

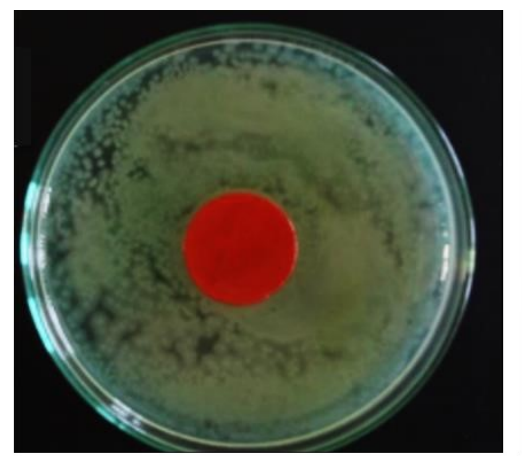

Filme de farinha WS

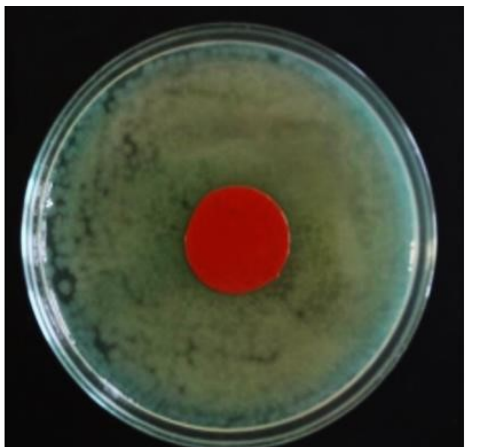

Filme de farinha AS

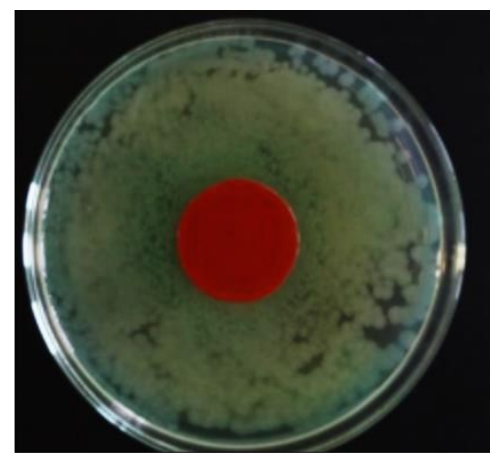

Filme de farinha KS

Figura 4.9 - Teste do halo dos filmes de farinhas de urucum (WS, AS e KS) com Escherichia coli (5 x 104UFC)

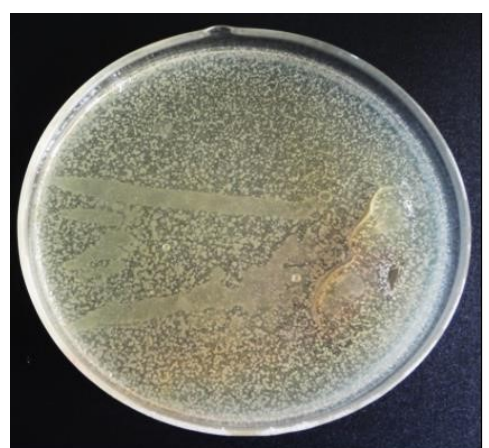

Controle

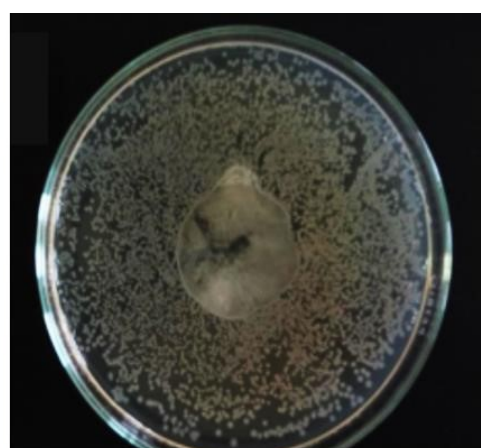

Filme controle de amido de mandioca

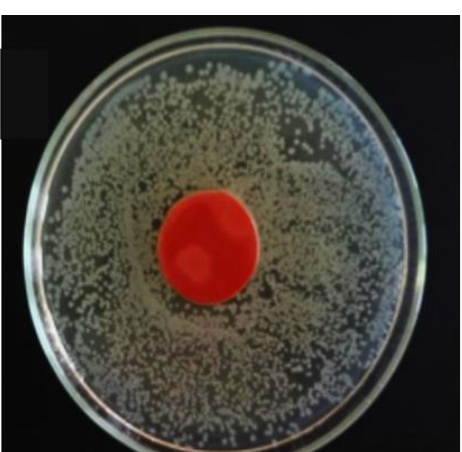

Filme de farinha WS

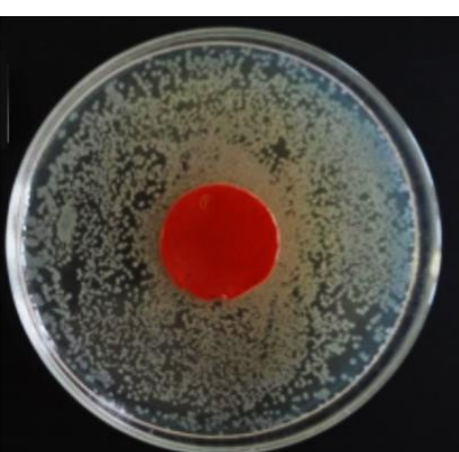

Filme de farinha AS

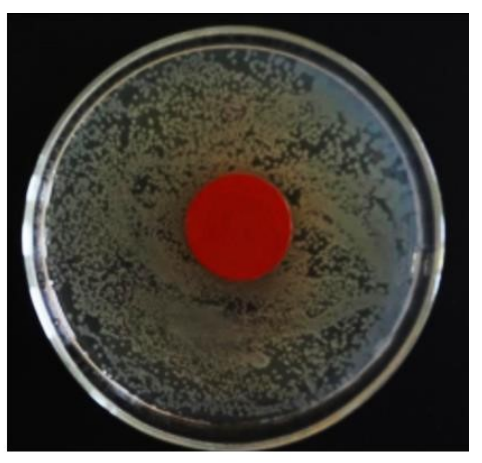

Filme de farinha KS 
Figura 4.10 - Teste do halo dos filmes de farinhas de urucum (WS, AS e KS) com Candida albicans (5 x 104 UFC)

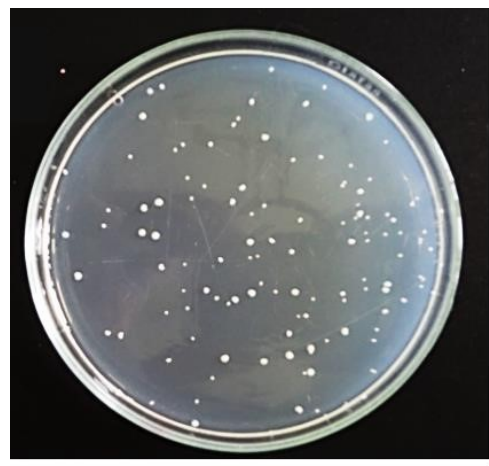

Controle

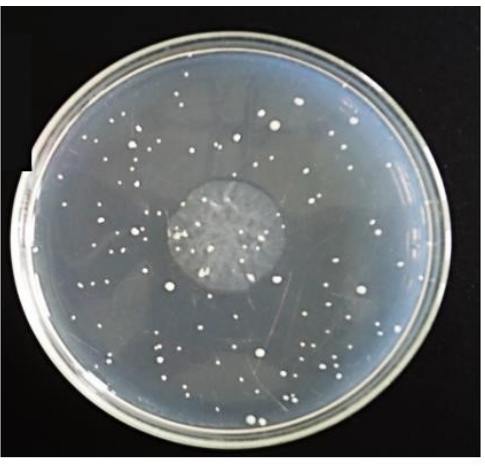

Filme controle de amido de mandioca

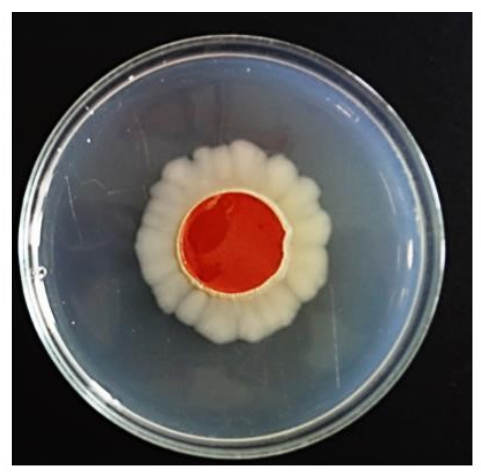

Filme de farinha WS

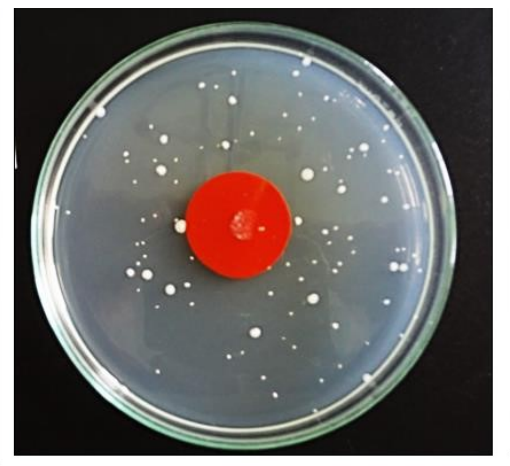

Filme de farinha AS

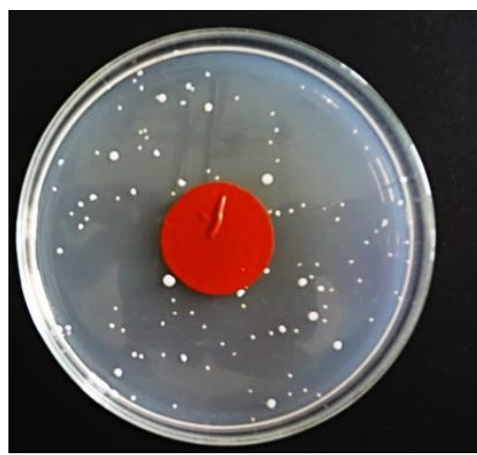

Filme de farinha KS

Figura 4.11 - Teste do halo dos filmes de farinhas de urucum (WS, AS e KS) com Aspergillus fumigatus (5 x 104 UFC)

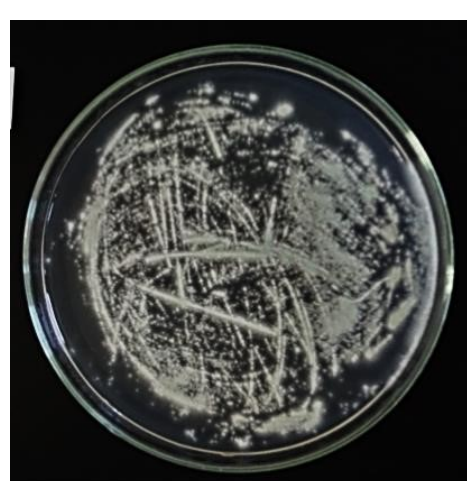

Controle

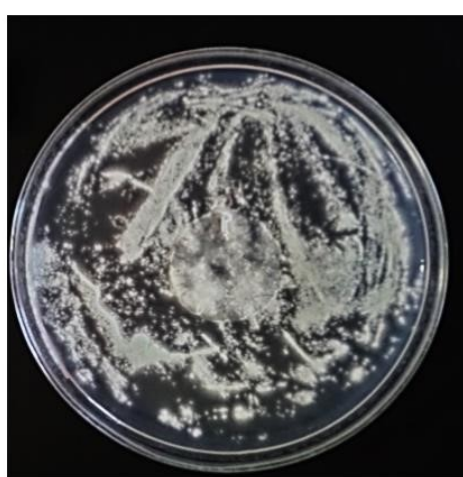

Filme controle de amido de mandioca

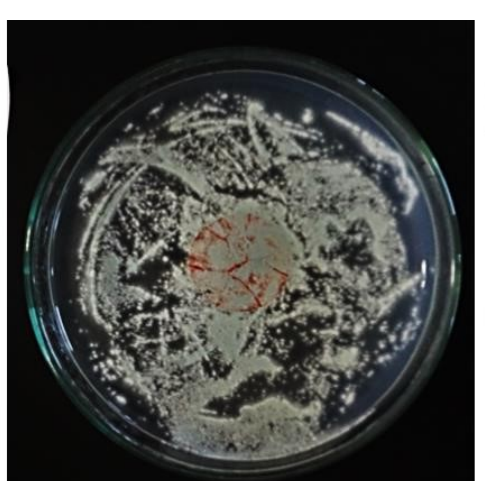

Filme de farinha WS

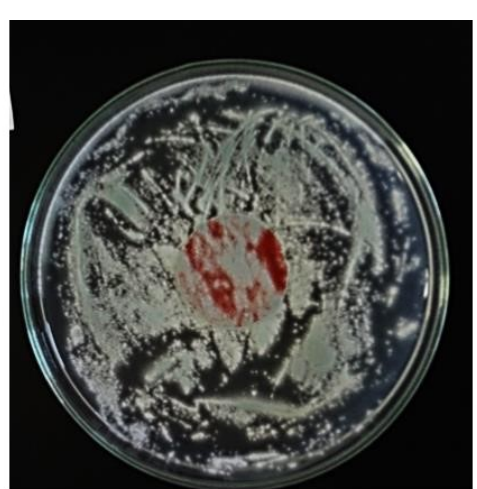

Filme de farinha AS

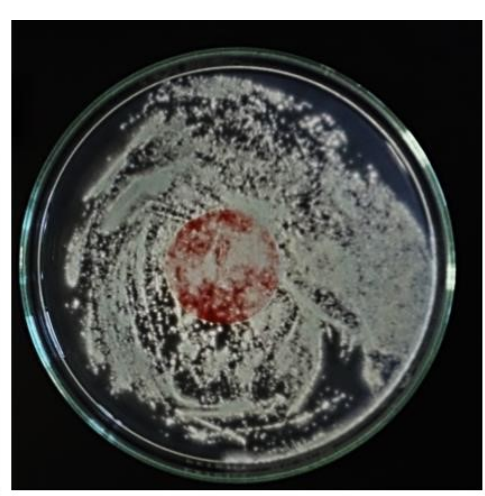

Filme de farinha KS 
Figura 4.12 - Teste do halo dos filmes de farinhas de urucum (WS, AS e KS) com Aspergillus tamarri (5 x $10^{4}$ UFC)

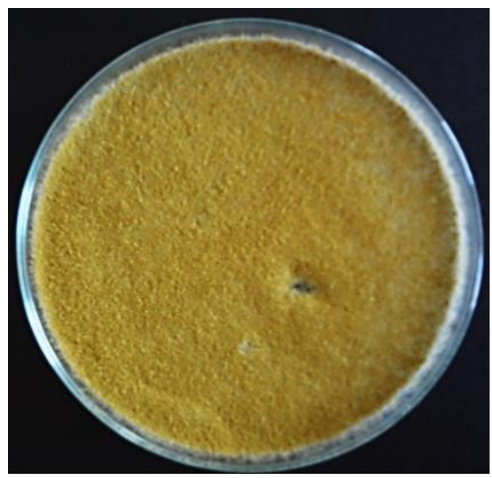

Controle

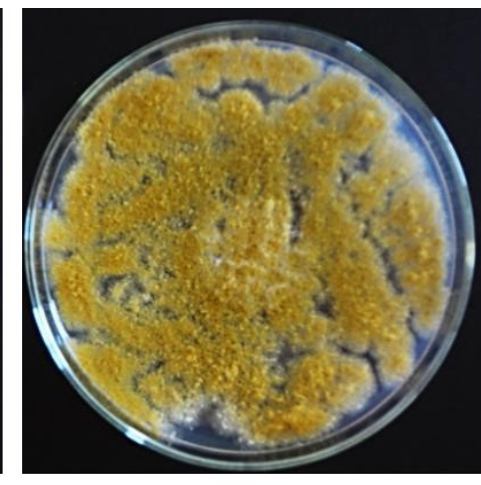

Filme controle de amido de mandioca

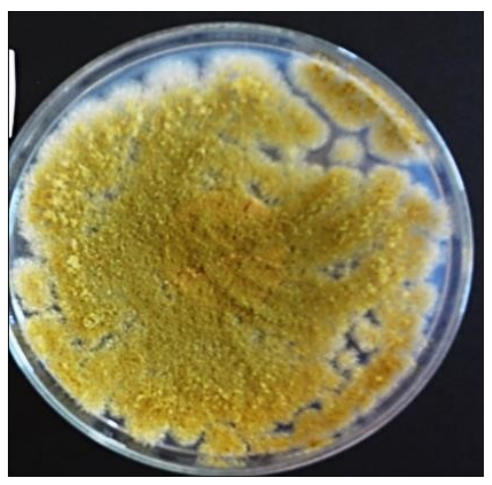

Filme de farinha WS

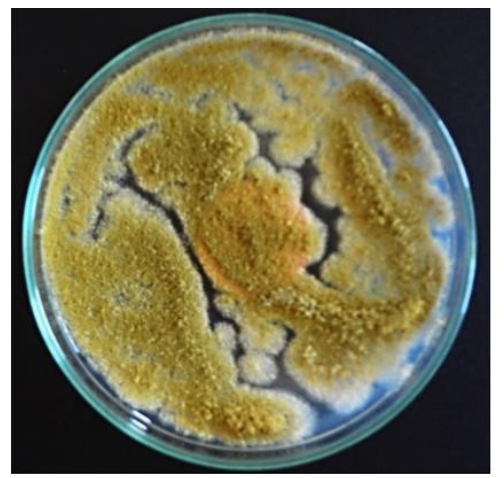

Filme de farinha AS

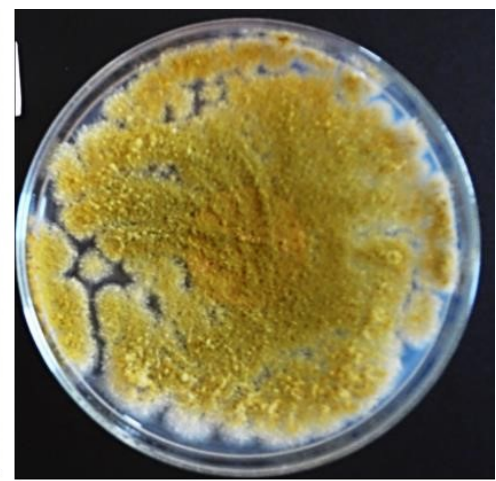

Filme de farinha KS

Figura 4.13 - Teste do halo dos filmes de farinhas de urucum (WS, AS e KS) com Fusarium oxysporum (5 x 10 ${ }^{4}$ UFC)

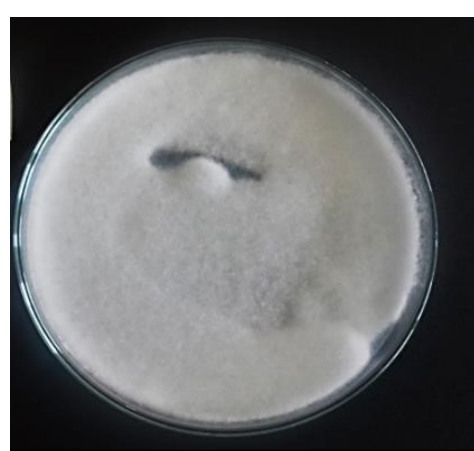

Controle

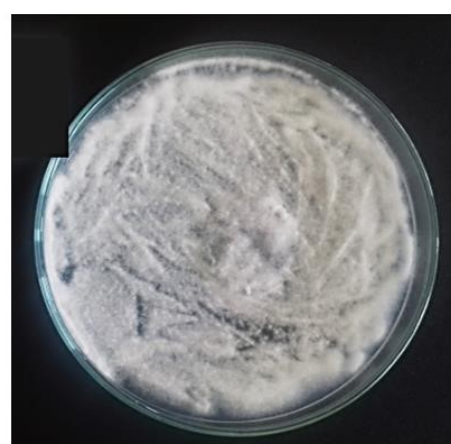

Filme controle de amido de mandioca

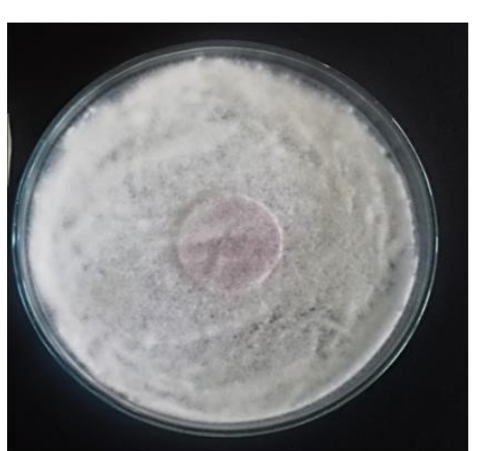

Filme de farinha WS

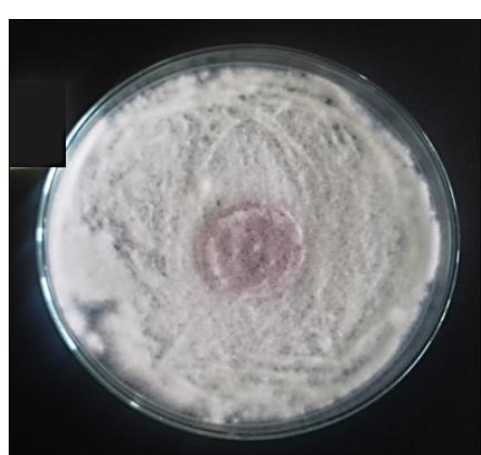

Filme de farinha AS

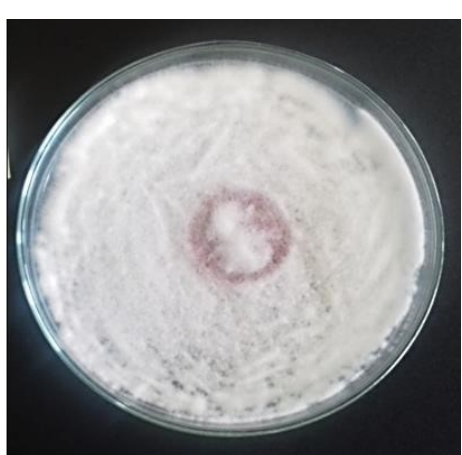

Filme de farinha KS 
Figura 4.14 - Teste do halo dos filmes de farinhas de urucum (WS, AS e KS) com Mucor sp (5 x $\left.10^{4} \mathrm{UFC}\right)$

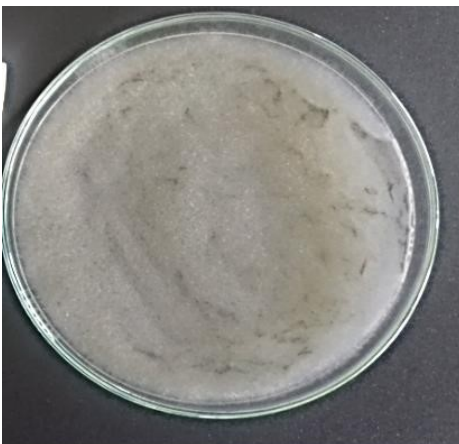

Controle

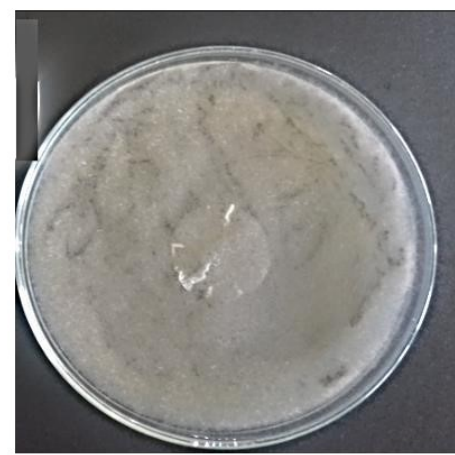

Filme controle de amido de mandioca

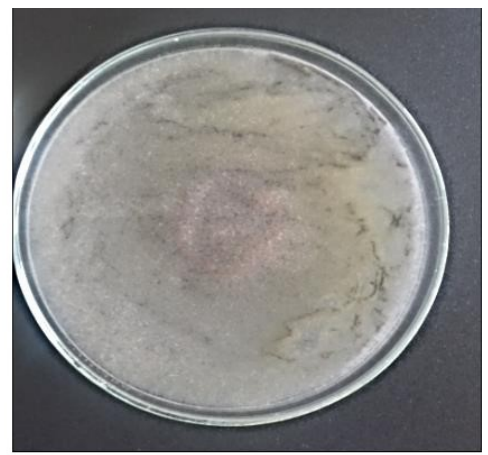

Filme de farinha WS

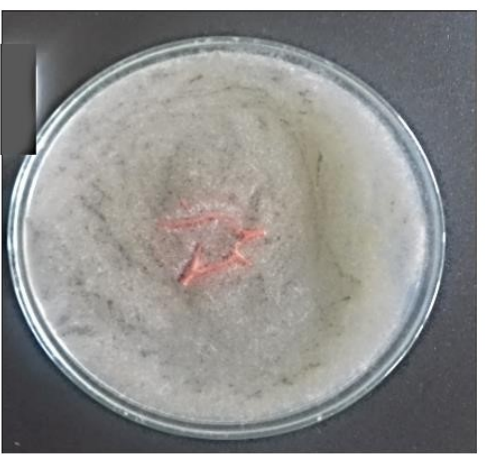

Filme de farinha AS

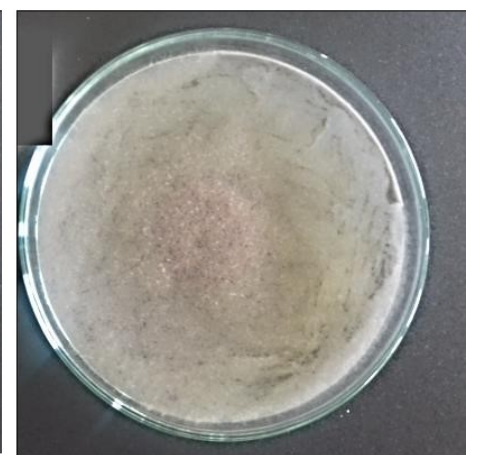

Filme de farinha KS

Figura 4.15 - Teste do halo dos filmes de farinhas de urucum (WS, AS e KS) com Aspergillus flavus (5 x 104UFC)

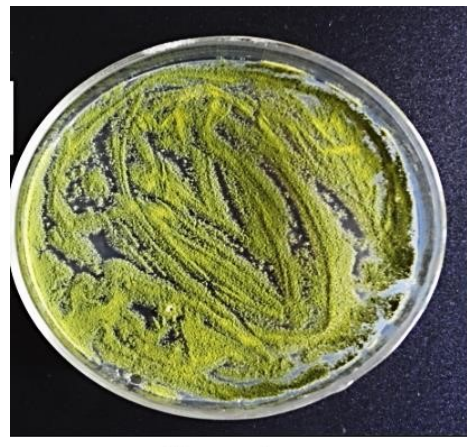

Controle

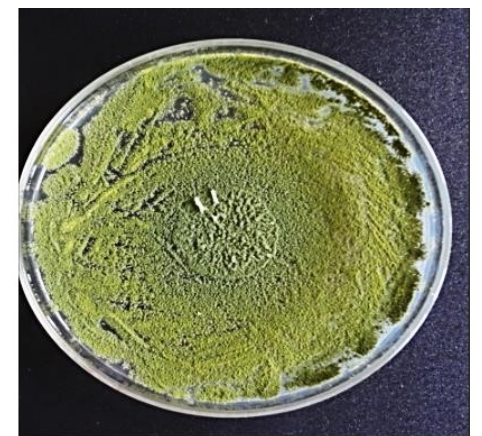

Filme controle de amido de mandioca

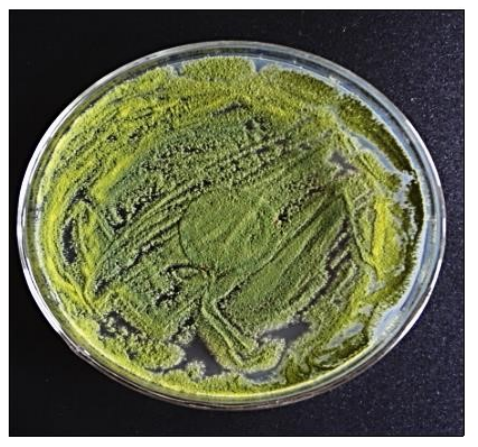

Filme de farinha WS

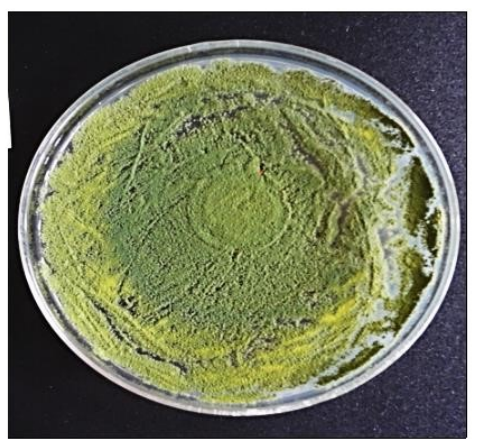

Filme de farinha AS

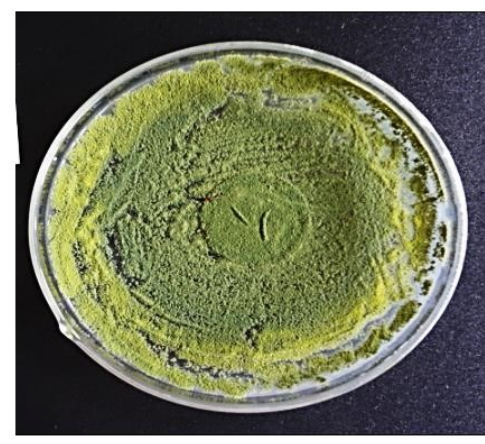

Filme de farinha KS 
Figura 4.16 - Teste do halo dos filmes de farinhas de urucum (WS, AS e KS) com Penicillium expansum (5 x 10 $\left.{ }^{4} \mathrm{UFC}\right)$

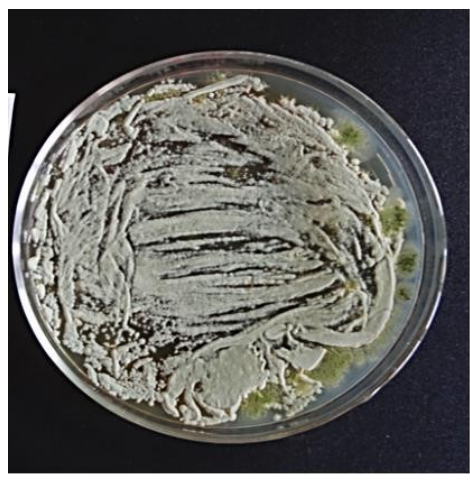

Controle

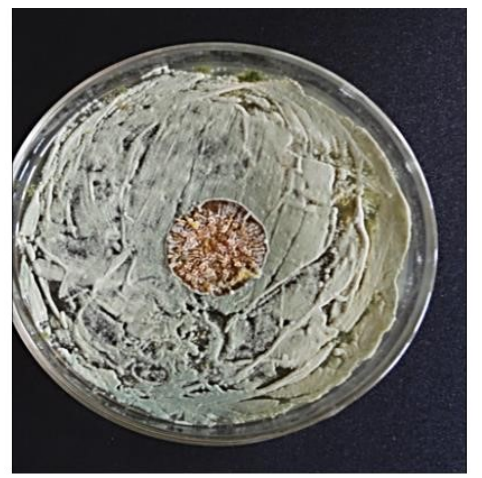

Filme controle de amido de mandioca

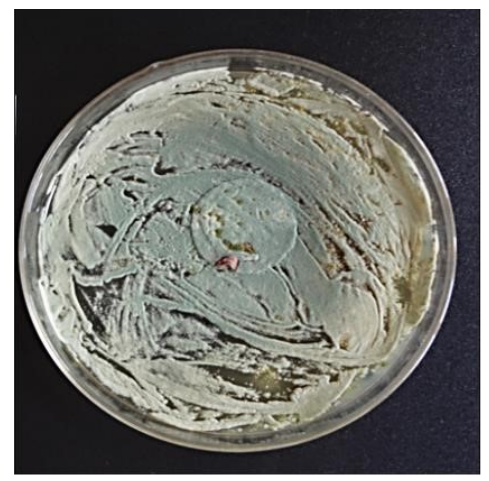

Filme de farinha WS

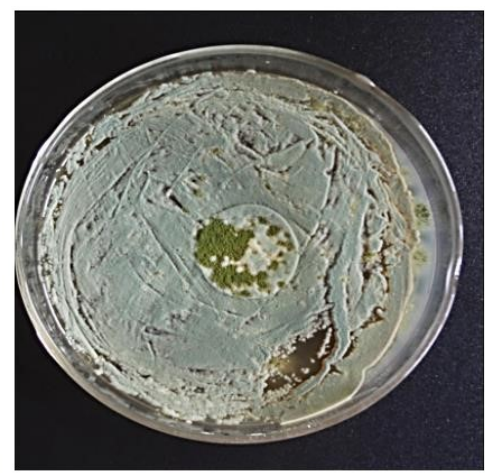

Filme de farinha AS

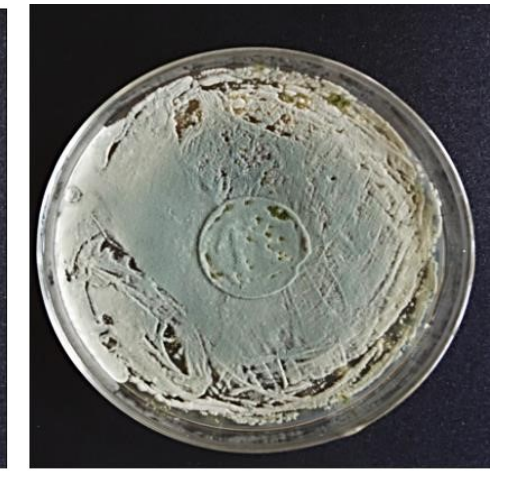

Filme de farinha KS 


\subsection{Conclusão}

Os filmes de farinha de urucum WS, AS, e KS são considerados ativos pela capacidade antioxidante. O filme de farinha de urucum AS apresentou-se como o de maior atividade antioxidante entre os demais. O extrato hidro-alcoólico das sementes de Bixa orellana apresentou atividade antimicrobiana contra $S$. aureus, $S$. uberis e $S$. agalactiae devido a estas bactérias serem mais sensíveis aos compostos ativos por serem Gram-positivas e permitirem a difusão dos compostos ativos na membrana e reduziram a esporulação de fungos $A$. fumigatus e Mucor sp. $\mathrm{O}$ extrato do rizoma de cúrcuma apresentou eficiência antimicrobiana contra Sthapylococcus aureus, Sthapylococcus uberis, Sthapylococcus agalactiae e Candida albicans, além de redução na esporulação de fungos Aspergillus tamarri, Aspergillus flavus, Fusarium oxysporum e Penicillium expansum. O filme de farinha de urucum KS, mostrou atividade antimicrobiana ao não permitir crescimento das bactérias S. aureus, S. uberis, E. coli, P. aeruginosa, L. monocytogenes e da levedura $C$ albicans.

\subsection{Referências Bibliográficas}

AKRAN, M. . et al. Curcuma longa and curcumin: a review article. Romanian Journal of Biology - Plant Biology, v. 55, p. 65-70, 2010.

BARRY, A. .; THORNSBERRY, C. Susceptibility tests: Diffusion Test Procedures. Manual of clinical microbiology., v. 5, p. 1117-1125, 1991.

BIANCO, K. G. et al. Evaluation of antimicrobial activity of plant extracts from Brazilian savanna on cariogenic cocci. Arch Health Invest, v. 6, n. 4, p. 172-176, 2017.

CARVALHO, D. DE M. et al. Filme ativo de acetato de celulose incorporado com nanosuspensão de curcumina. Polímeros, v. 27, 2017.

CASTELLO, M. et al. Antimicrobial activity of crude extracts from plant parts and corresponding calli of Bixa orellana L. Indian J Exp Biol., v. 40, n. 12, p. 1378-81, 2002.

CASTRO, R. W. ET AL. Qualidade do preparado para bebida obtido a partir de polpa de juçara submetida ao tratamento térmico. Brazilian Journal of Food Technology, v. 19, 2016.

DIAS DA SILVA, R. . Pharmacopéia dos Estados Unidos do Brasil. São Paulo: Companhia Editora Nacional, 1929.

FEITOR, M. . Efeito Antibacteriano de Tecidos Têxteis Revestidos por Prata Através da Técnica de Deposição por Plasma. Natal: [s.n.].

FILHO, A. B. C. . et al. Cúrcuma: planta medicinal, condimentar e de outros usos potenciais. Ciência Rural, v. 30, n. 1, p. 171-175, 2000.

FILHO, C. R. M. S. . et al. Avaliação da bioatividade de extratos cúrcuma (Curcuma longa L., 
Zingiberaceae) em Artemia salina e Biomphalaria glabrata. Revista Brasileira de Farmacognosia, v. 19, n. 4, p. 919-923, 2009.

FLEISCHER, T. C. et al. Antimicrobial activity of the leaves and seeds of Bixa orellana. Fitoterapia, v. 74, n. 1-2, p. 136-8, fev. 2003.

FRANCO, C. F. O. et al. Urucuzeiro: Agronegócio de Corantes Naturais. Emepa ed. João Pessoa: SAIA, 2002.

FRATIANNI, A.; CINQUANTA, L.; PANFILI, G. Degradation of carotenoids in orange juice during microwave heating. LWT - Food Science and Technology, v. 43, p. 867-871, 2010.

FURLANETTO, M. C. S. Desenvolvimento de filmes de carboximetilcelulose com nanopartículas de prata e avaliação de sua atividade antimicrobiana e toxicidade. São Carlos: ., 2014.

GALINDO-CUSPINERA, V.; LUBRAN, M. B.; RANKIN, S. A. Comparison of volatile compounds in water- and oil-soluble annatto (Bixa orellana L.) extracts. Journal of agricultural and food chemistry, v. 50, n. 7, p. 2010-5, 27 mar. 2002.

GONÇALVES, A. L.; FILHO, A. A.; MENEZES, H. ESTUDO COMPARATIVO DA ATIVIDADE ANTIMICROBIANA DE EXTRATOS DE ALGUMAS ÁRVORES NATIVAS. Arq. Inst. Biol., v. 72, n. 3, p. 353-358, 2005.

GROSS, J. Carotenoids. In: GROSS, J. (Ed.). . Pigments in vegetables, Chlorophylls and Carotenoids. London: Academic Press, 1991. p. 75-335.

HASSIMOTTO, N. M. A.; GENOVESE, M. I.; LAJOLO, F. M. Antioxidant Activity of Dietary Fruits, Vegetables, and Commercial Frozen Fruit Pulps. Journal of Agricultural and Food Chemistry, v. 53, n. 8, p. 2928-2935, abr. 2005.

HILLIS, W. E.; SWAIN, T. The phenolic constituents ofPrunus domestica. II.-The analysis of tissues of the Victoria plum tree. Journal of the Science of Food and Agriculture, v. 10, n. 2, p. 135-144, fev. 1959.

IROBI, O. N.; MOO-YOUNG, M.; ANDERSON, W. A. ANTIMICROBIAL ACTIVITY OF ANNATTO (BIXA ORELLANA) EXTRACT. International Journal of Pharmacognosy, v. 34, n. 2, p. 87-90, 1996.

KREPKER, M. et al. Active food packaging films with synergistic antimicrobial activity. Food Control, v. 76, p. 117-126, 2017.

LO ET AL. Accumulation of 3-deoxyanthoxyanidin phytoalexins and resistance to Colletotrichum sublineolum in sorghum. Physiological and Molecular Plant Pathology, v. 55, p. 263-273, 1996.

MANIGLIA, B. C. et al. Turmeric dye extraction residue for use in bioactive film production: Optimization of turmeric film plasticized with glycerol. LWT - Food Science and Technology, v. 64, n. 2, p. 1187-1195, dez. 2015.

MORAES, S. .; ALVES, S. . Quantificação de inoculo de patógenos de insetos. Controle Microbiano de Insetos., v. 14, p. 278-288, 1986.

MORS, W. .; RIZZINI, C. .; PEREIRA, N. A. Medicinal plants of Brazil. Michigan: Reference Publications. Medicinal plants of Brazil., p. 372, 2000. 
MORTENSEN, A. Carotenoids and other pigments as natural colorants. Pure and Applied Chemistry, v. 78, n. 8, 1 jan. 2006.

OETARI, S. et al. Effects of curcumin on cytochrome P450 and glutathione S-transferase activities in rat liver. Biochemical pharmacology, v. 51, n. 1, p. 39-45, 12 jan. 1996.

OLIVEIRA, P. H. R. D. Phenol (CAS 108-95-2). Revista Virtual de Química, v. 7, n. 4, p. 1579-1593, 2015.

PEREIRA, A. S. ; STRINGHETA, P. C. Considerações sobre a cultura e processamento do açafrão. Horticultura Brasileira, v. 16, n. 2, p. 102-105, 1998.

PÉRET-ALMEIDA, L. . et al. Atividade antimicrobiana in vitro do rizoma em pó dos pigmentos curcuminóides e dos óleos essenciais da Curcuma longa L. Ciência e Agrotecnologia, v. 32, n. 3, p. 875-881, 2008.

RIOS, A. DE O.; MERCADANTE, A. Z.; BORSARELLI, C. D. Triplet state energy of the carotenoid bixin determined by photoacoustic calorimetry. Dyes and Pigments, v. 74, n. 3, p. 561-565, jan. 2007.

ROLIM, M. T. Avaliação da eficácia do açafrão (Curcuma longa L.) no controle de Stapghylococcus aureus em queijo prato. Revistade Patologia Tropical, v. 33, n. 3, 2004.

RUFINO, M. DO S. M. et al. Metodologia Científica: Determinação da Atividade Antioxidante Total em Frutas pela Captura do Radical Livre ABTS +. . 2007.

SCHIOZER, A. L.; BARATA, L. E. S. Stability of Natural Pigments and Dyes. Revista Fitos, 2007.

SCHWAN-ESTRADA, K. R. F.; STANGARLIN, J. R.; CRUZ, M. E. DA S. Uso de extratos vegetais no controle de fungos fitopatogênicos. Floresta, v. 30, n. 1/2, p. 129-137, 2000.

SHADOMY, S. \& SPINEL-INGROF, A. Susceptibility testing: with antifungal drugs. LENNETTE, ed. Washington: American Society for Microbiology,: Manual of clinical of microbiology. 3, 1980.

SHAHID-UL-ISLAM; RATHER, L. J.; MOHAMMAD, F. Phytochemistry, biological activities and potential of annatto in natural colorant production for industrial applications - A review. Journal of Advanced Research, v. 7, n. 3, p. 499-514, 2015.

SHILPI, J. A. et al. Preliminary pharmacological screening of Bixa orellana L. leaves. Journal of Ethnopharmacology, v. 108, p. 264-271, 2006.

YOUNES, R.N.; VARELLA, A.D.; SUFFREDINI, I. B. Extração e rastreamento de novas drogas em plantas brasileiras. Acta Oncológica Brasileira, v. 20, p. 15-19, 2000.

YUAN, G.; CHEN, X.; LI, D. Chitosan films and coatings containing essential oils: The antioxidant and antimicrobial activity, and application in food systems. Food Research International, 2016.

ZHAI, B. et al. Antimalarial Evaluation of the Chemical Constituents of Hairy Root Culture of Bixa orellana L. Molecules, v. 19, n. 1, p. 756-766, 2014.

DIAS DA SILVA, R.A. Pharmacopéia dos Estados Unidos do Brasil. São Paulo: Companhia Editora Nacional, 1929. 634p. 
YOUNES, R.N.; VARELLA, A.D.; SUFFREDINI, I.B. Extração e rastreamento de novas drogas em plantas brasileiras. Acta Oncológica Brasileira, v.20, p.15-19, 2000 


\section{CONSIDERAÇÕES GERAIS}

O resíduo de urucum apresentou composição rica em amido e presença de compostos ativos. A partir da moagem em água, em $\mathrm{pH}$ ácido e em $\mathrm{pH}$ alcalino do resíduo de urucum foi possível obter um material com maior grau de pureza em amido em relação ao materialinicial, sendo então consideradas farinhas WS, AS e KS. Os métodos de isolamento empregados permitiram a obtenção farinhas com propriedades diferenciadas tanto em composição química quando nas propriedades térmicas, físicas e macroestruturais. O planejamento fatorial completo $3 \times 3 \times 4$ permitiu o estudo das melhores condições de produção dos filmes. De acordo com os resultados do planejamento, as melhores condições para elaboração de filmes de farinha de urucum com melhores propriedades mecânicas e funcionais foram $\mathrm{pH} 5$ e 2 horas de aquecimento quando utilizado a farinha KS. Nestas condições de $\mathrm{pH}$ e tempo de aquecimento verificou-se que os filmes de farinha KS foram menos hidrofílicos com menor capacidade de absorção de umidade, menos solúveis, mais permeáveis ao vapor de água e mais resistentes mecanicamente quando comparados aos filmes WS e AS. O maior teor de amido e amilose na farinha KS permitiram obter filmes KS com melhores propriedades mecânicas. O pH ácido (5) favoreceu a formação de interações amido-proteína, proteína-proteína, amido-fibra, promovendo a formação de uma matriz coesa. Os filmes de farinha de urucum WS, AS, e KS apresentaram baixa atividade antioxidante em relação a matéria-prima inicial (fonte de compostos ativos), devido ao processo de elaboração que pode ter degradado parte dos compostos ativos contidos na matriz. Entre os filmes, o filme AS apresentou-se como o de maior atividade antioxidante. $\mathrm{O}$ extrato hidro-alcoólico das sementes de Bixa orellana apresentou atividade antimicrobiana contra $S$. aureus, $S$. uberis e $S$. agalactiae devido a estas bactérias serem mais sensíveis aos compostos ativos por serem Gram-positivas e permitirem a difusão dos compostos ativos na membrana, além de reduzir a esporulação de fungos A. fumigatus $e$ Mucor sp. O filme de farinha de urucum KS, mostrou atividade antimicrobiana ao não permitir crescimento das bactérias S. aureus, S. uberis, E. coli, P. aeruginosa, L. monocytogenes e da levedura $C$ albicans. Portanto, este trabalho comprova o potencial aproveitamento do resíduo da extração de corante de urucum na produção de filmes biodegradáveis ativos, podendo ser utilizados como coberturas antioxidantes e/ou antimicrobianas. Contudo, é importante ressaltar a necessidade de estudos futuros que identifiquem temperaturas menores para formação dos filmes, já que a $85^{\circ} \mathrm{C}$ houve perdas de compostos ativos. 


\section{SUGESTÕES PARA TRABALHOS FUTUROS}

Para dar continuidade a este trabalho com o resíduo de urucum pode-se sugerir para trabalhos futuros:

- Caracterização reológica das suspensões filmôgenicas das farinhass de urucum WS, AS, e KS para aprofundar o conhecimento das propriedades dessas suspensões e o tipo de interações moleculares formadas entre os componentes da mistura;

- Estudo da biodegradabilidade destes filmes;

- Estudo da aplicação de coberturas destes filmes elaborados a partir das farinhas de urucum para a conservação de alimentos;

- Determinação de concentração inibitória mínima (bacteriostático) e determinação de concentração inibitória máxima (bactericida) do extrato de urucum contra microrganismos;

- Incorporação de agente antimicrobiano a matriz para verificar o aumento da eficiência da atividade antimicrobiana. 


\section{SOBRE A AUTORA}

Nascida em Nepomuceno, Minas Gerais, no dia 20 de Setembro de 1990. Estudou em escola pública até a $8^{\circ}$ série. O ensino médio foi feito na escola particular Abreu Carvalho, rede POSITIVO de ensino. Foi aprovada no curso de Engenharia de Alimentos, na Universidade Federal de Lavras em 2009, curso integral com duração de cinco anos. Aluna de bom rendimento acadêmico, fez iniciação científica, participou de congressos, núcleo de estudos, foi trainee, gerente e diretora de qualidade na empresa júnior, foi membro do centro acadêmico de engenharia de alimentos, realizou estágios. Ao se formar foi contratada pela empresa que estagiou por um ano. Em junho de 2015 foi aprovada no mestrado do Departamento de Química da USP-RP. Durante o mestrado, cursou cinco disciplinas, em todas foi conceituada com A. Participou do EnqBiotec 2015, no qual fez uma apresentação de trabalho oral. Co-orientou o trabalho de conclusão de curso da aluna Malorie Guyon do Département de Chimie do IUT de Poitiers da França, que esteve em nosso grupo de pesquisa por três meses. Foi aluna-monitora da disciplina de Tecnologia de Alimentos dos alunos do curso de química. Com parte dos resultados deste projeto de mestrado, referentes principalmente ao Capítulo 2, publicou um artigo na revista Food Hydrocolloids, com o seguinte título: "Is isolating starch from the residue of annatto pigment extraction feasible?". Ainda com os demais resultados do mestrado, pretende publicar mais um artigo. 